University of Louisville

ThinkIR: The University of Louisville's Institutional Repository

$12-2014$

\title{
Mechanistic investigations of pseudouridine synthases : a surprising glycal intermediate lies on the reaction pathway.
}

Govardhan reddy Veerareddygari

University of Louisville

Follow this and additional works at: https://ir.library.louisville.edu/etd

Part of the Genetics and Genomics Commons

\section{Recommended Citation}

Veerareddygari, Govardhan reddy, "Mechanistic investigations of pseudouridine synthases : a surprising glycal intermediate lies on the reaction pathway." (2014). Electronic Theses and Dissertations. Paper 1734.

https://doi.org/10.18297/etd/1734

This Doctoral Dissertation is brought to you for free and open access by ThinkIR: The University of Louisville's Institutional Repository. It has been accepted for inclusion in Electronic Theses and Dissertations by an authorized administrator of ThinkIR: The University of Louisville's Institutional Repository. This title appears here courtesy of the author, who has retained all other copyrights. For more information, please contact thinkir@louisville.edu. 


\title{
MECHANISTIC INVESTIGATIONS OF PSEUDOURIDINE SYNTHASES-A SURPRISING GLYCAL INTERMEDIATE LIES ON THE REACTION PATHWAY
}

\author{
By \\ Govardhan reddy Veerareddygari \\ M.S., University of Louisville, 2012 \\ M.Sc., Osmania University, 2006

\begin{abstract}
A Dissertation
Submitted to the Faculty of the

College of Arts and Sciences of the University of Louisville

in Partial Fulfillment of the Requirements

for the Degree of
\end{abstract}

Doctor of Philosophy

Department of Chemistry

University of Louisville

Louisville, Kentucky

December, 2014 



\title{
MECHANISTIC INVESTIGATIONS OF PSEUDOURIDINE SYNTHASES-A SURPRISING GLYCAL INTERMEDIATE LIES ON THE REACTION PATHWAY
}

\author{
By
}

Govardhan reddy Veerareddygari

M.S., University of Louisville, 2012

M.Sc., Osmania University, 2006

A Dissertation Approved on

December 10, 2014

By the Following Dissertation Committee:

\begin{tabular}{c}
\hline Dissertation Director \\
Professor Eugene G. Mueller \\
\hline Professor Muriel C. Maurer \\
\hline Professor Christine V. Rich \\
\hline Professor Steven Van Lanen
\end{tabular}




\section{DEDICATION}

This dissertation is dedicated to my parents

Late Mr. Anantha reddy Veerareddygari

and

Mrs. Vijaya Lakshmi Veerareddygari

Without your emotional support and intellectual guidance, I would not have made it this far. Thank you. 


\section{ACKNOWLEDGEMENTS}

I owe my deepest gratitude to my mentor, Dr. Eugene G. Mueller. His insightful guidance allowed me to think critically and to develop a constructive thought process. I had the great opportunity of taking his course in Biochemistry during my first year at the graduate school which spiked my interest to pursue research in the field of enzymology. His vast knowledge allowed me to learn valuable research skills that I hope to apply through my career. Without his helpful guidance, I would never have completed this dissertation. Thank you.

I thank my committee members, Dr. Muriel C. Maurer, Dr. Christine V. Rich, and Dr. Steven Van Lanen for their insightful advice, guidance, support and helpful suggestions. I owe many thanks especially to Dr. Muriel C. Maurer for the knowledge and intellectual experience that I have gained as her teaching assistant

during the first four years of my graduate life. I owe Dr. Christine V. Rich for refreshing my knowledge in organic chemistry and spectroscopy through her advanced spectroscopy lectures. I thank Dr. Steven Van Lanen for generously providing the plasmids required for the overexpression of enzymes. 
I thank my previous lab mates, Dr. Sanjay K. Singh who was always willing to help when I needed it the most, Dr. Edward J. Miracco who taught me how to handle enzymes, and had been offering continuous help even after graduating, Dr. Menakshi Bansal for her expertise with RNA techniques, Yizhou Xie for his help with benchwork. I would like to thank my current lab member James Ladd for sharing his knowledge in synthetic chemistry.

I thank Dr. Neal J. Stolowich for his help with running NMR, Dr. Bogdan Bogdanov and Dr. Pawel Lorkiewicz for helping me with the acquisition of FT-MS data.

I owe a debt of gratitude to the Milliner family (Sarah and Scott Milliner), and their two beautiful daughters (Norah and Isabel), and the Raeuchle family (Clara and Keith Raeuchle) for their extended hospitality that made my life in Louisville a pleasant one.

I thank my former and present colleagues at the department of Chemistry including Katherine Sellers, Mohamed Marei, Sébastien Laulhé, and Rajat Chauhan for all the fun times and valuable discussions that we had.

I thank the taxpayers who funded my research through $\mathrm{NIH}$, and the University of Louisville "Bucks for Brains" program. 


\begin{abstract}
MECHANISTIC INVESTIGATIONS OF PSEUDOURIDINE SYNTHASES-A

SURPRISING GLYCAL INTERMEDIATE LIES ON THE REACTION PATHWAY
\end{abstract}

Govardhan reddy Veerareddygari

December 10, 2014

Pseudouridine synthases ( $\Psi S s$ ) catalyze the isomerization of uridine $(U)$ in RNA to pseudouridine $(\Psi)$, which is the most common post-transcriptional modification in RNAs and is ubiquitous within all three domains of life. $\Psi$ Ss are classified into six different families based on sequence alignments and have a universally conserved aspartic acid residue ('conserved Asp' for simplicity) that is absolutely essential for activity. RNA containing 5-fluorouridine ([$\left.\left.F^{5} U\right] R N A\right)$ has been used as a mechanistic probe. Upon incubation with [ $\left.\mathrm{F}^{5} \mathrm{U}\right] \mathrm{RNA}$, TruA and RluA get irreversibly inhibited and appear in a protein-RNA adduct band on denaturing PAGE gels, which is consistent with the 'Michael mechanism' that proposes a covalent adduct between the conserved Asp and the pyrimidine ring. E. coli TruB does not get inhibited upon incubation with $\left[F^{5} U\right] R N A$, nor does it form an adduct and instead converts $\mathrm{F}^{5} \mathrm{U}$ into two rearranged, hydrated products. ${ }^{18} \mathrm{O}$ labeling studies with the E. coli $\Psi$ Ss TruA, TruB, RluA, and TruD show that the 
hydration of the products of $\mathrm{F}^{5} \mathrm{U}$ occurs directly from solution and not through the hydrolysis of a Michael adduct. These ${ }^{18} \mathrm{O}$ labeling studies were extended here to Thermotoga maritima TruB (TmTruB) which showed a behavior intermediate between that of $E$. coli TruB (no observed adduct; multiple turnovers) and RluA and TruA (stoichiometric adduction; single turnover). ${ }^{18} \mathrm{O}$ label is incorporated into RNA directly from solvent during the reaction of $\left[F^{5} U\right]$ RNA catalyzed by TmTruB. These results are consistent with the scheme proposed earlier for the handling of $\mathrm{F}^{5} \mathrm{U}$ by $\Psi \mathrm{Ss}$. Among examined $\Psi \mathrm{Ss}, \mathrm{TmTruB}$ uniquely shows the interesting ability to catalyze the dehydration and rehydration of the products of $\mathrm{F}^{5} \mathrm{U}$.

The minor product of $\mathrm{F}^{5} \mathrm{U}$ from the action of $\Psi \mathrm{Ss}$ is an arabino isomer and its generation requires epimerization at $\mathrm{C2}^{\prime}$, which suggested that the $\Psi S$ mechanism may proceed by deprotonation of $\mathrm{C}^{\prime}$ to eliminate the uracil and form a glycal intermediate. To test this mechanistic possibility, substrate RNA stemloops containing $\left[2^{\prime}-{ }^{2} \mathrm{H}\right]$ uridine were prepared and used to measure the deuterium kinetic isotope effect on the conversion of $U$ to $\Psi$. Deuteration at $C 2$ ' reduced both $V_{\max }$ and $V_{\max } / K_{\mathrm{m}}$ for the reaction as catalyzed by TruB (2.54-fold and 3.58-fold, respectively) and RluA (1.79-fold and 2.17-fold, respectively). These results conclusively indicate that the deprotonation of $\mathrm{C}^{\prime}$ occurs in a partially ratedetermining step in the conversion of $U$ to $\Psi$, which is consistent with the 'glycal mechanism' but inconsistent with the proposed alternatives. 
TABLE OF CONTENTS

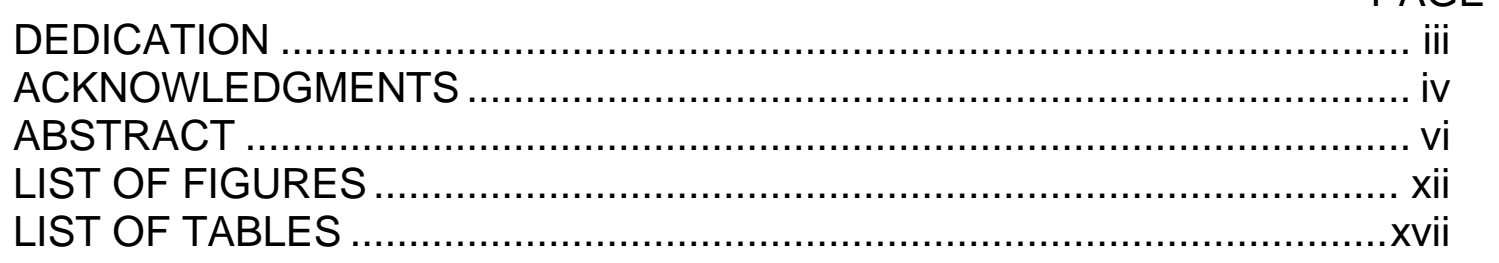

CHAPTER 1. PSEUDOURIDINE AND PSEUDOURIDINE SYNTHASES .......1

Pseudouridine and its physiological significance................................. 1

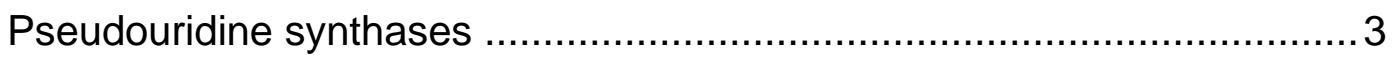

Proposed mechanisms for $\Psi$ synthases ................................................ 5

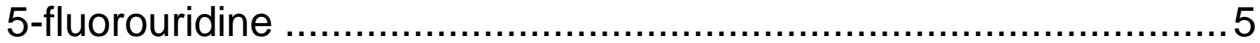

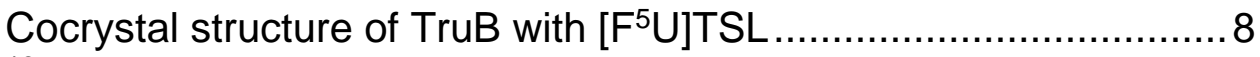

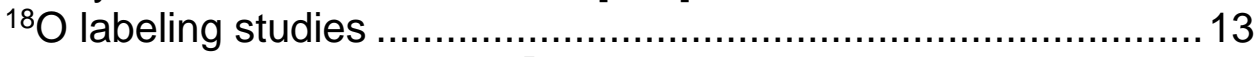

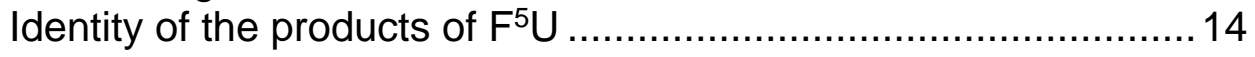

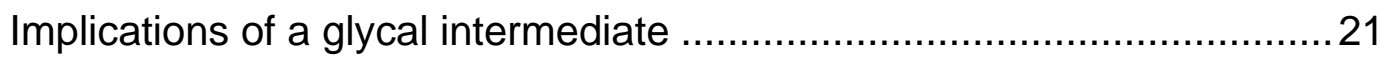

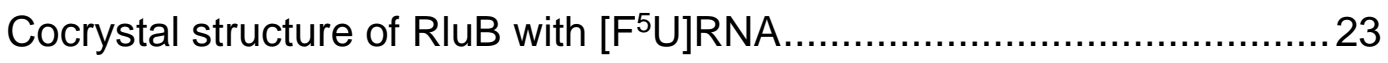

The interesting case of Thermotoga maritima TruB (TmTruB) ................24

The possibility of an active site Tyr forming the Michael adduct 28

CHAPTER 2. MECHANISTIC INVESTIGATIONS OF THERMOTOGA MARITIMA

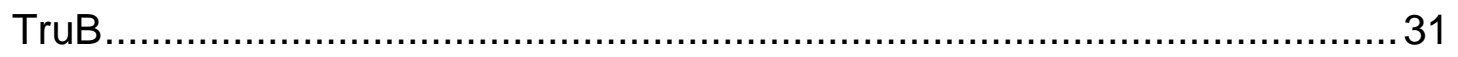

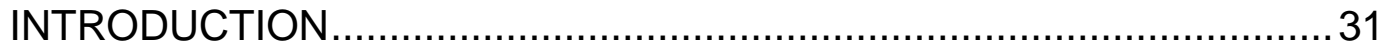

Pseudouridine synthase TruB .............................................. 31

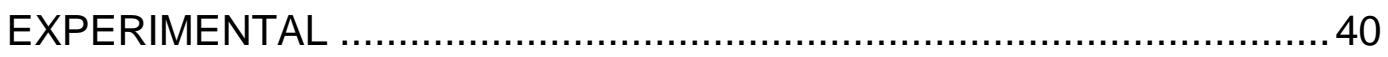

Materials ......................................................................... 40

Subcloning, overexpression, and purification of wild-type and

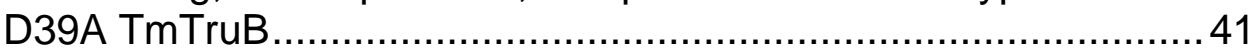

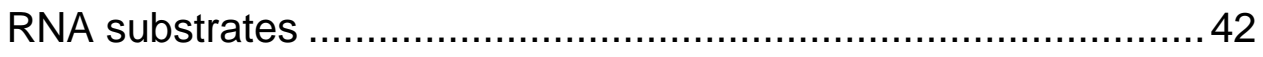


Digestion and MALDI-MS analysis of TmTruB and TmTSL.......... 42

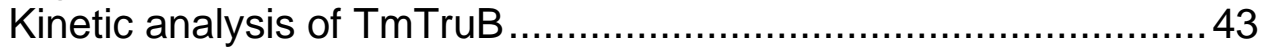

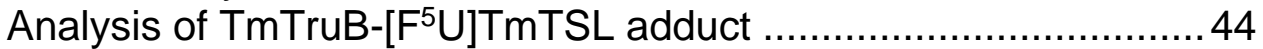

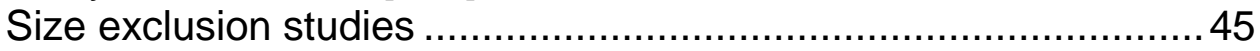

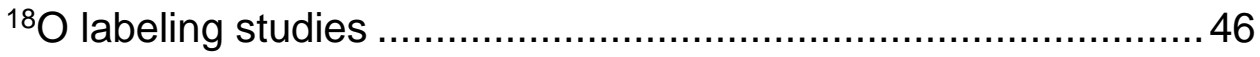

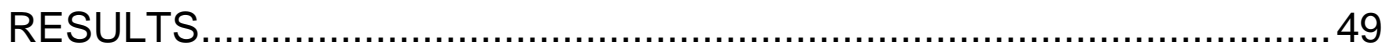

Subcloning, overexpression, and purification of TmTruB ............. 49

Kinetic characterization of TmTruB........................................51

Quench conditions..................................................... 51

Reaction temperature and choice of substrates ...................51

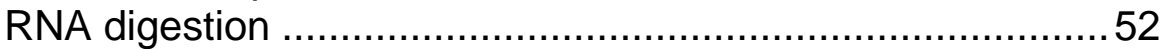

Reaction buffer and enzyme concentration .........................53

Steady state kinetic parameters for TmTruB .......................56

Adduct formation between TmTruB and [F5]TMTSL ..................59

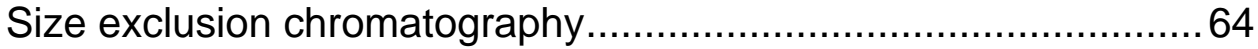

Time course for the formation of $\left[\mathrm{F}^{5} \mathrm{U}^{*}\right] \mathrm{TmTSL} \ldots \ldots \ldots \ldots \ldots \ldots \ldots \ldots . . .68$

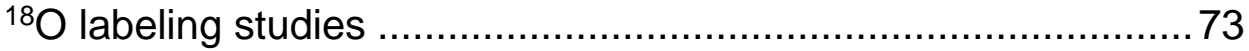

Characterization of TmTruB and [ $\left.\mathrm{F}^{5} \mathrm{U}\right] \mathrm{TmTSL}$ by mass

spectrometry ................................................................ 73

Controls for ${ }^{18} \mathrm{O}$ exchange ........................................... 74

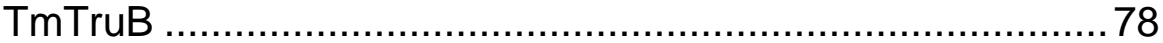

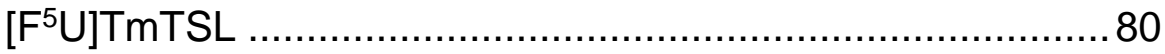

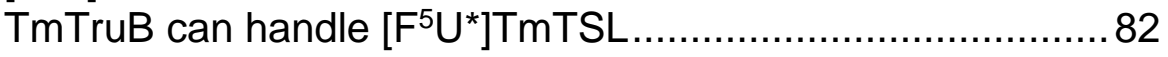

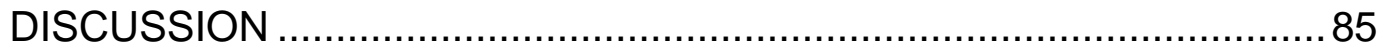

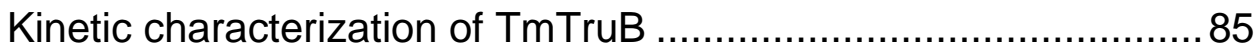

Adduct formation between TmTruB and [F5]]TmTSL ..................85

Implications for the turnover of [ $\left.\mathrm{F}^{5} \mathrm{U}\right] \mathrm{TmTSL}$ by TmTruB ...............88

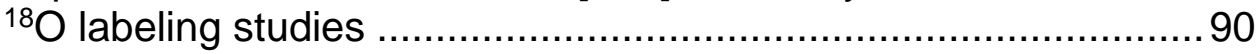

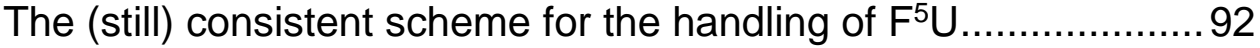

CHAPTER 3. DEUTERIUM WASH-IN STUDIES TO PROBE THE GLYCAL MECHANISM ..................................................................

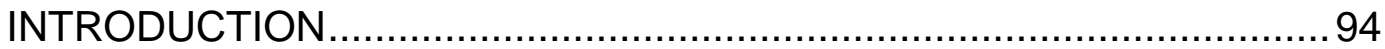

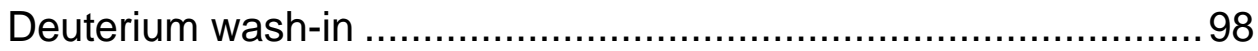

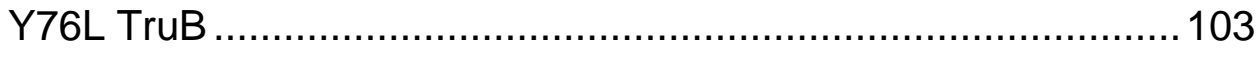

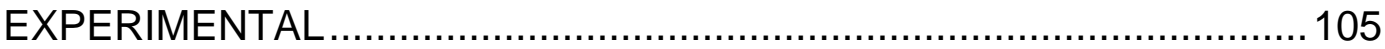

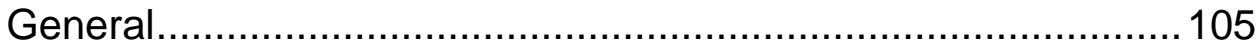

Subcloning, overexpression and purification of Y76L TruB ......... 105

Digestion and MALDI-MS of Y76L TruB ...................................106

Pepsin digestion......................................................... 106

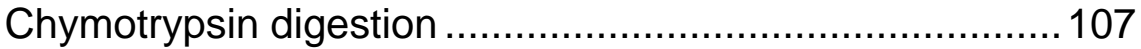

Analysis of Y76L TruB and [F5]TSL reaction........................... 107 
Inhibition of Y76L TruB by [F5]TSL ............................ 108

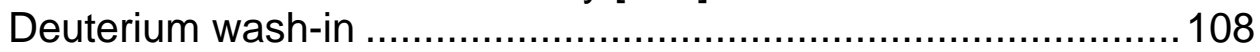

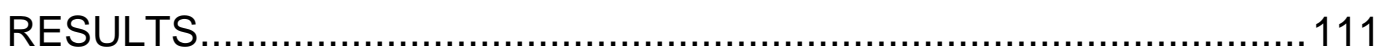

In silico analysis .............................................................111

Subcloning, overexpression, and purification of Y76L TruB ........111

MALDI-MS of Y76L TruB....................................................115

Reaction of Y76L TruB with [F $\left.F^{5}\right]$ TSL ..................................115

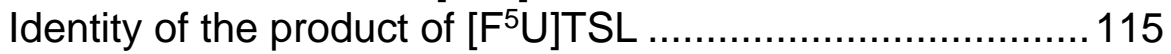

SDS-PAGE analysis ....................................................118

Time course for the formation of $\left[F^{5} U^{*}\right] T S L . \ldots \ldots \ldots \ldots \ldots \ldots \ldots . . . \ldots 118$

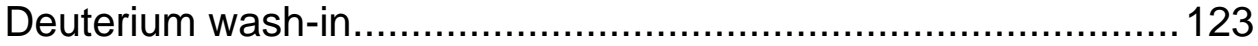

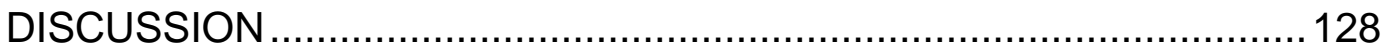

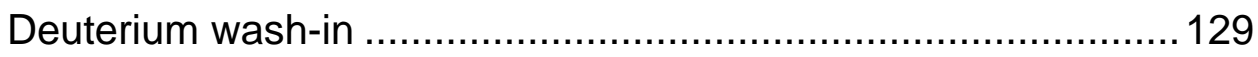

High resolution mass spectrometry.................................129

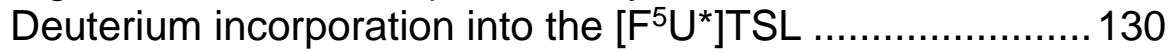

CHAPTER 4. DEUTERIUM KINETIC ISOTOPE EFFECT STUDIES TO

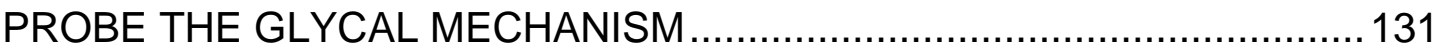

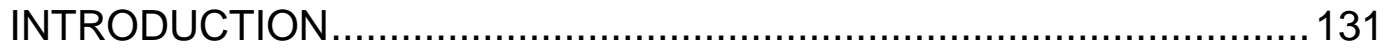

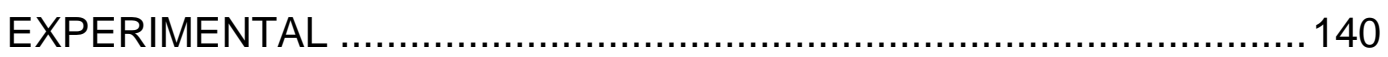

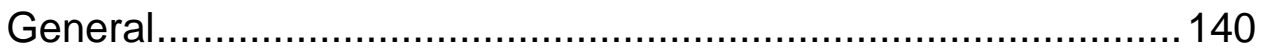

Enzymatic synthesis of [2'-2H]UTP ...................................... 141

Subcloning, overexpression, and purification.................... 141

Ribokinase assay ....................................................... 142

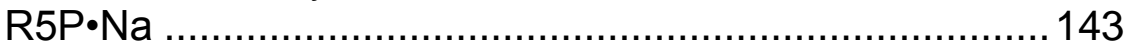

PRPP synthetase assay ......................................... 143

UPRTase assay ……............................................ 143

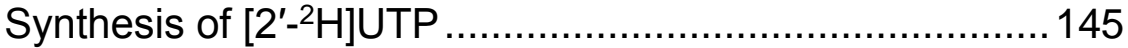

In vitro transcription of RNA substrates ................................... 146

Digestion of transcripts and MALDI-MS ….............................. 148

Kinetic assays ……............................................................. 149

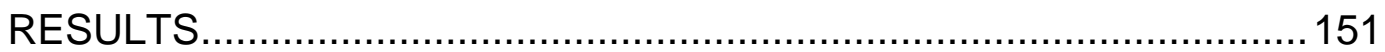

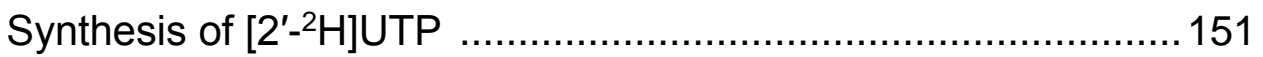

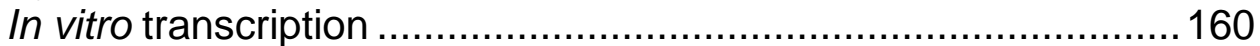

Sequence verification of transcripts.....................................161

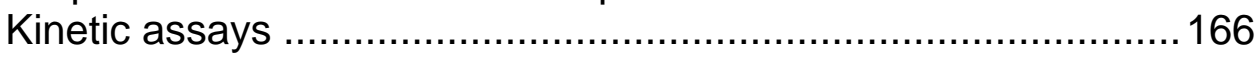

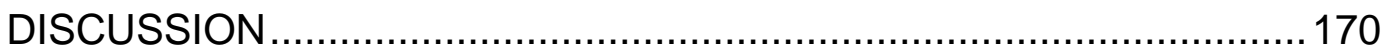

In vitro transcription ............................................................ 171

Deuterium kinetic isotope effect studies ................................. 172 
Overall conclusions

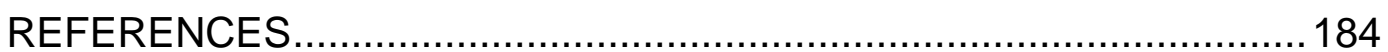

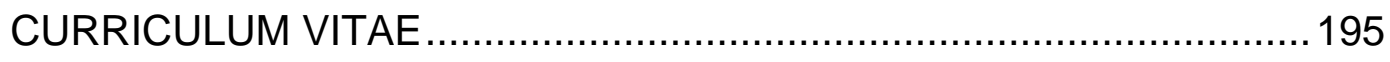




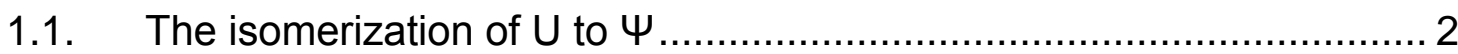

1.2. The classic 'cloverleaf' representation of E. coli tRNA ${ }^{\text {Phe }} \ldots \ldots \ldots \ldots \ldots \ldots . . . .6$

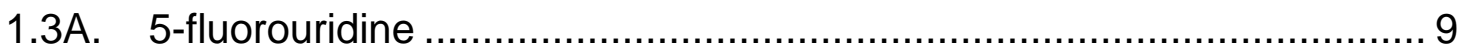

1.3B. The Michael adduct between TruA and $\left[\mathrm{F}^{5} \mathrm{U}\right] \mathrm{RNA}$ proposed by Santi and co-workers ……...................................... 9

1.4. The Michael mechanism ........................................................... 10

1.5A. The hydrated $F^{5} \mathrm{U}$ product proposed by Santi and co-workers .......... 11

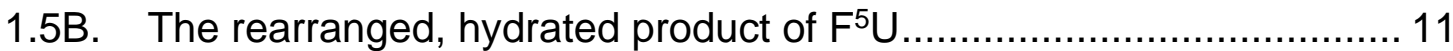

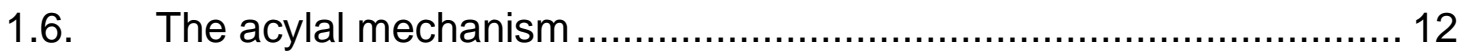

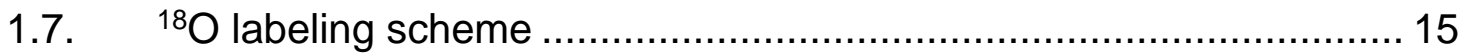

1.8 The proposed consistent scheme for the handling of $F^{5} \mathrm{U}$ in RNA by different $\Psi$ synthases .................................................. 16

1.9. The major and minor products of $\mathrm{F}^{5} \mathrm{U}^{*}$ differ in stereo configuration of $\mathrm{C}^{\prime}$......................................................... 18

1.10. The 'glycal' mechanism for $\Psi$ formation ....................................... 19

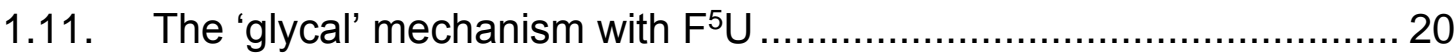

1.12. The acylal mechanism recast to emphasize features that can account for the arabino product of $\mathrm{F}^{5} \mathrm{U}$

1.13. A close up view of the active site from the cocrystal structure of RluB and $\left[F^{5} \mathrm{U}\right] \mathrm{RNA}$ reported by Stroud and co-workers 
1.14. The modified Michael mechanism proposed by

Stroud and co-workers.

1.15. The consistent scheme proposed by Mueller and co-workers with mild revision to account for the arabino product of $\mathrm{F}^{5} \mathrm{U}$

1.16. The interaction of TmTruB and $\left[F^{5} \mathrm{U}\right] \mathrm{RNA}$ 30

2.1. The Michael adduct proposed by Santi and co-workers for TruA ...... 35

2.2. An overlay of the cocrystal structures of EcTruB and TmTruB with [F5]RNA. 36

2.3. Scheme for the ${ }^{18} \mathrm{O}$ labeling studies 37

2.4. The proposed consistent scheme for the handling of $F^{5} \mathrm{U}$ in RNA by different $\Psi$ synthases

2.5. SDS-PAGE analysis of the induction and overexpression of TmTruB 50

2.6. Stem-loop RNAs tested as substrates for TmTruB 54

2.7A. Endpoint assays of the activity of TmTruB with TmTSL ${ }^{\cup} \ldots \ldots \ldots \ldots \ldots \ldots . \ldots 5$

2.7B. Time course for the reaction of TmTSL ${ }^{\cup}$ catalyzed by TmTruB ......... 55

2.8. Steady state kinetic analysis of TmTruB ........................................ 58

2.9. Denaturing PAGE analysis of TmTruB-[ $\left.\mathrm{F}^{5} \mathrm{U}\right] \mathrm{TmTSL}$ adduct formation 60

2.10. Replicates of adduction trials with TmTruB and [ $\left.\mathrm{F}^{5} \mathrm{U}\right] \mathrm{TmTSL}$ and analysis by urea-PAGE

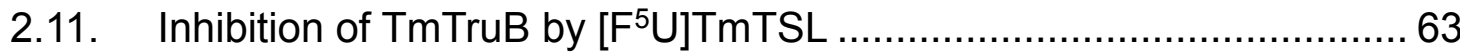

2.12. Theoretical trace for size exclusion chromatography........................6 65

2.13A. Overlay of traces from size exclusion chromatography of standards and TmTruB. in phosphate buffer

2.13B Overlay of traces from size exclusion chromatography of standards and TmTruB. in Tris buffer 66 
2.14. Plot of $\mathrm{K}_{\mathrm{av}}$ versus $\log \left(M_{\mathrm{r}}\right)$ for standards and TmTruB in phosphate buffer and in Tris buffer.

2.15. Size exclusion chromatography studies of the

TmTruB- [ $\left.\mathrm{F}^{5} \mathrm{U}\right] \mathrm{TmTSL}$ adduct.

2.16. Urea-PAGE (12\%, $7 \mathrm{M}$ urea) analysis of the reaction between

TmTruB $(5 \mu \mathrm{M})$ and $\left[\mathrm{F}^{5} \mathrm{U}\right] \mathrm{TmTSL}(50 \mu \mathrm{M})$.

2.17. Time course for the conversion of [ $\left.\mathrm{F}^{5} \mathrm{U}\right] \mathrm{TmTSL}(50 \mu \mathrm{M})$ upon incubation with $\operatorname{TmTruB}(5 \mu \mathrm{M})$.... 72

2.18. Partial mass spectrum of the tryp/Glu-C digestion peptides from TmTruB 75

2.19. ${ }^{18} \mathrm{O}$ labeling studies. Partial mass spectra of trypsin/Glu-C digestion peptides for TmTruB showing the peptide containing Asp-39.

2.20. ${ }^{18} \mathrm{O}$ labeling studies. Partial mass spectra of RNaseT1-digested $\left[\mathrm{F}^{5} \mathrm{U}\right] \mathrm{TmTSL}$ showing the oligonucleotide containing $\mathrm{F}^{5} \mathrm{U}$.

2.21. Partial mass spectra for the RNase $T 1$ digests of $\left[F^{5} U^{*}\right] T m T S L$.

$A$, Adduction reaction and heat disruption in buffer containing $\left[{ }^{18} \mathrm{O}\right]$ water $(50 \%, \mathrm{v} / \mathrm{v})$. B, Pre-formed $\left[\mathrm{F}^{5} \mathrm{U}^{*}\right] \mathrm{TmTSL}$ incubated with TmTruB in buffer containing $\left[{ }^{18} \mathrm{O}\right]$ water $(50 \%, \mathrm{v} / \mathrm{v})$ immediately prior to the heating.

2.22. Crystal structures of TmTruB. A, Bound with RNA. B, Unbound. .... 89

2.23. The slightly revised scheme of Mueller and co-workers that still accounts for all the observed results 93

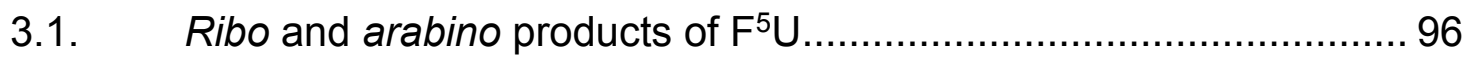

3.2. The acylal mechanism recast to emphasize features that can account for the arabino product of $F^{5} \mathrm{U}$

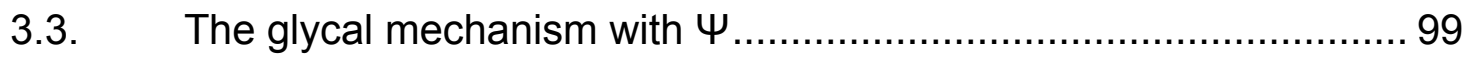

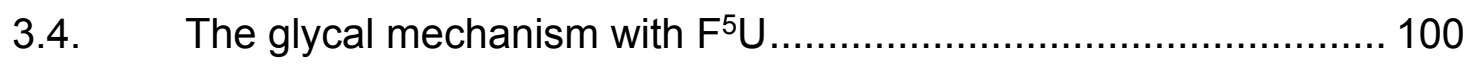

3.5. Deuterium wash-in scheme for the glycal mechanism with $F^{5} U . \ldots 101$ 
3.6. Mass spectra for the deuterium wash-in studies on RluA with $\mathrm{U}$ and $\left[\mathrm{F}^{5} \mathrm{U}\right]$ containing RNAs . 102

3.7. HPLC analysis of reaction products of 5FU-RNA incubated with

E. coli $\Psi 55 \mathrm{~S}$ wild-type or $\mathrm{Y} 76$ mutants by Phannachet et al.

3.8. An in silico comparison of the active sites of TruB variants.

A, Y76L TruB. B, wild-type TruB

3.9. Space-filling view of the active site of TruB variants.

A, Y76L TruB. B, Y76L TruB.

3.10. SDS-PAGE analysis of the overexpression and purification of Y76L TruB

3.11. Partial mass spectra of the peptides from the chymotryptic digestion of Y76L and wild-type TruB

3.12. Partial HPLC trace of the products of $F^{5} U$ from the action of wild-type and Y76L TruB

3.13. SDS-PAGE analysis (10\% gel) of the reaction between Y76L TruB and [ $\left.\mathrm{F}^{5} \mathrm{U}\right] \mathrm{TSL}$

3.14. Inhibition of $\mathrm{Y} 76 \mathrm{~L}$ TruB by $\left[\mathrm{F}^{5} \mathrm{U}^{*}\right] \mathrm{TSL}$

3.15. Comparative FT-MS of the purified dinucleotide $\mathrm{F}^{5} \mathrm{U}^{*} \mathrm{pC} \ldots \ldots \ldots \ldots \ldots .124$

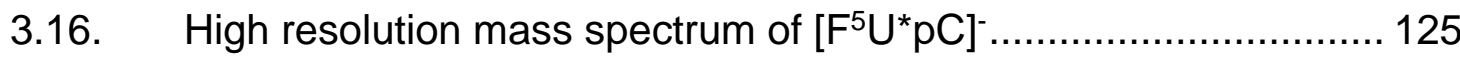

4.1. The 'Michael mechanism' for $\Psi$ synthases.................................. 132

4.2. The 'acylal mechanism' for $\Psi$ formation .................................... 133

4.3. The proposed 'glycal mechanism' for $\Psi$ formation........................ 136

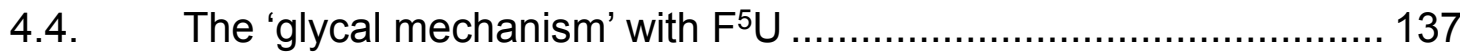

4.5. The glycal mechanism with $\left[2^{\prime}-{ }^{2} \mathrm{H}\right] \mathrm{U}$ containing substrate. ........... 139

4.6. Schemes of the activity assays for the overexpressed enzymes... 144

4.7. Ribokinase overexpression as monitored by SDS-PAGE............. 152

4.8. Purification of enzymes for the synthesis of UMP as monitored by SDS-PAGE 
4.9. Enzymatic synthesis scheme for $\left[2^{\prime}-{ }^{2} \mathrm{H}\right]$ UTP ............................... 156

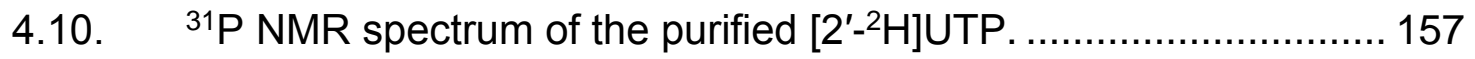

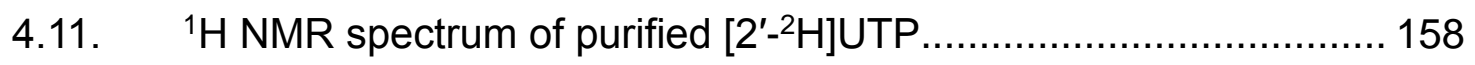

4.12. Comparison of the ${ }^{1} \mathrm{H}$ NMR spectra of $\left[2^{\prime}-{ }^{2} \mathrm{H}\right] \mathrm{UTP}$

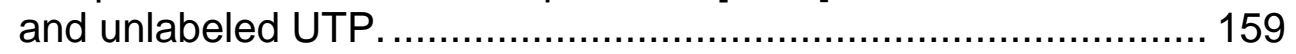

4.13. In vitro transcription results for TSL........................................ 162

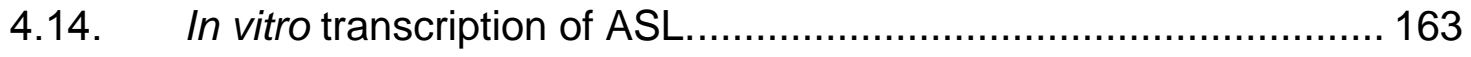

4.15. Partial MALDI-TOF mass spectra for the RNase T1 digests of unlabeled and labeled TSL ...................................................... 164

4.16. Partial MALDI-TOF mass spectra for the RNase T1 digests of unlabeled and labeled ASL...................................................... 165

4.17. Briggs-Haldane fit $\left(\mathrm{R}^{2}=0.99\right)$ for the kinetics of TruB with TSL

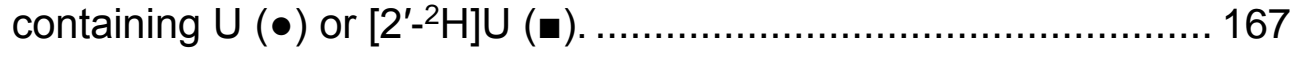

4.18. Briggs-Haldane fit $\left(R^{2}=0.98\right)$ for the kinetics of RluA with ASL

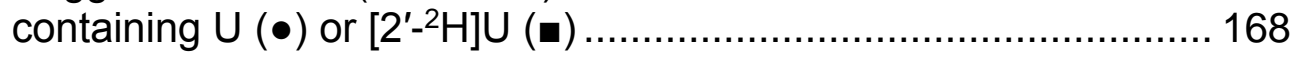

4.19. The primary ${ }^{2} \mathrm{KIE}$. Zero-point energy differences for a $\mathrm{C}-\mathrm{H}$ bond compared to that of a C-D bond 


\section{LIST OF TABLES}

TABLE

PAGE

2.1. Initial velocity $\left(v_{0}\right)$ data for $\operatorname{TmTruB}(1.5 \mathrm{nM})$ with a range of TmTSL ${ }^{\cup}$ concentrations.

2.2. Changing ratios of adduct to free TmTruB and Free $\left[F^{5} U\right] T m T S L$ observed on urea-PAGE gels

2.3. Distribution of adduct, free TmTruB, and free [ $\left.\mathrm{F}^{5} \mathrm{U}\right] \mathrm{TmTSL}$ by urea-PAGE for the time course of the formation of the TmTruB-[F $\left.{ }^{5} \mathrm{U}\right] \mathrm{TmTSL}$ adduct.

2.4. Sequence coverage for the trypsin/Glu-C digest of wild-type TmTruB..76

2.5. Sequence coverage for the trypsin/Glu-C digest of D39A TmTruB ..... 77

2.6. Relative isotope intensities for $\mathrm{U}\left[\mathrm{F}^{5} \mathrm{U}^{\star}\right] \mathrm{CG}$ under different ${ }^{18} \mathrm{O}$ labeling regimes.

2.7. Kinetic parameters obtained for TmTruB in comparison to those for EcTruB and RluA.

3.1. Production of $\left[\mathrm{F}^{5} \mathrm{U}^{*}\right] \mathrm{TSL}$ observed for different ratios of Y76L TruB and [F5]TSL

3.2. $\left[\mathrm{F}^{5} \mathrm{U}^{*}\right] \mathrm{TSL}$ formed by $\mathrm{Y} 76 \mathrm{~L}$ TruB from $\left[\mathrm{F}^{5} \mathrm{U}\right] \mathrm{TSL}$ with or without pre-incubation of the enzyme with $\left[\mathrm{F}^{5} \mathrm{U}^{\star}\right] \mathrm{TSL}$

3.3. Mass spectral analysis (negative mode) of the dinucleotide product $\mathrm{F}^{5} \mathrm{U}^{*} \mathrm{pC}$ obtained from the action of $\mathrm{Y} 76 \mathrm{~L}$ TruB on $\left[\mathrm{F}^{5} \mathrm{U}\right] \mathrm{TSL}$ conducted in unlabeled and labeled buffers.

3.4. Mass spectral analysis (negative mode) of the dinucleotide product $\mathrm{F}^{5} \mathrm{U}^{*} \mathrm{pC}$ for the successive trials of wash-in experiments.

4.1. Specific activities for ribokinase, PRPP synthetase, and UPRTase . 154 xvii 
4.2. Kinetic parameters for TruB and RluA with substrates containing $U$

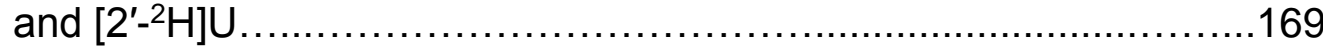

4.3. The quantitation of nucleoside peaks from the HPLC traces for kinetic assays of TruB with unlabeled TSL............................176

4.4. The quantitation of nucleoside peaks from the HPLC traces for kinetic assays of TruB with labeled TSL.

4.5. The quantitation of nucleoside peaks from the HPLC traces for kinetic assays of RluA with unlabeled ASL.

4.6. The quantitation of nucleoside peaks from the HPLC traces for kinetic assays of RluA with labeled ASL 


\section{CHAPTER 1}

\section{PSEUDOURIDINE AND THE PSEUDOURIDINE SYNTHASES}

Pseudouridine $(\Psi)$, the $C$-glycoside isomer of uridine $(U)$ is a ubiquitous constituent of structural RNAs, and it is the most common post-transcriptional modification in all three domains of life (Figure 1.1). The enzymes that catalyze this isomerization of $U$ to $\Psi$ are the pseudouridine synthases ( $\Psi$ synthases), and they use both sequence and structural information to achieve site-specific generation of $\Psi$ in particular RNA contexts. [1]

\section{Pseudouridine and its physiological significance}

The existence of $\Psi$ in yeast tRNA was reported in 1957, [2] and $\Psi$ was subsequently found in all non-coding RNAs. [2] In 1970, Johnson and Söll reported site-specific $\Psi$ synthase activity in Escherichia coli extracts. [3] Most recently, Carlile and co-workers reported $\Psi$ in mRNAs and showed that its occurrence is heavily regulated. [4] Pseudouridine is physically and chemically distinct from its parent uridine. The $\mathrm{C}-\mathrm{C}$ glycosidic bond in $\Psi$ exhibits enhanced rotational freedom as compared to the C-N glycosidic bond in U. [5] CD spectroscopy [6], nuclear magnetic resonance (NMR) studies, [6] and molecular dynamic simulations [7] all suggest that $\Psi$ imparts structural rigidity in both single- and double-stranded RNAs, possibly due to the free imino proton in $\Psi$ that can act as an additional hydrogen bond donor. [8] The presence of $\Psi$ in an anti configuration 


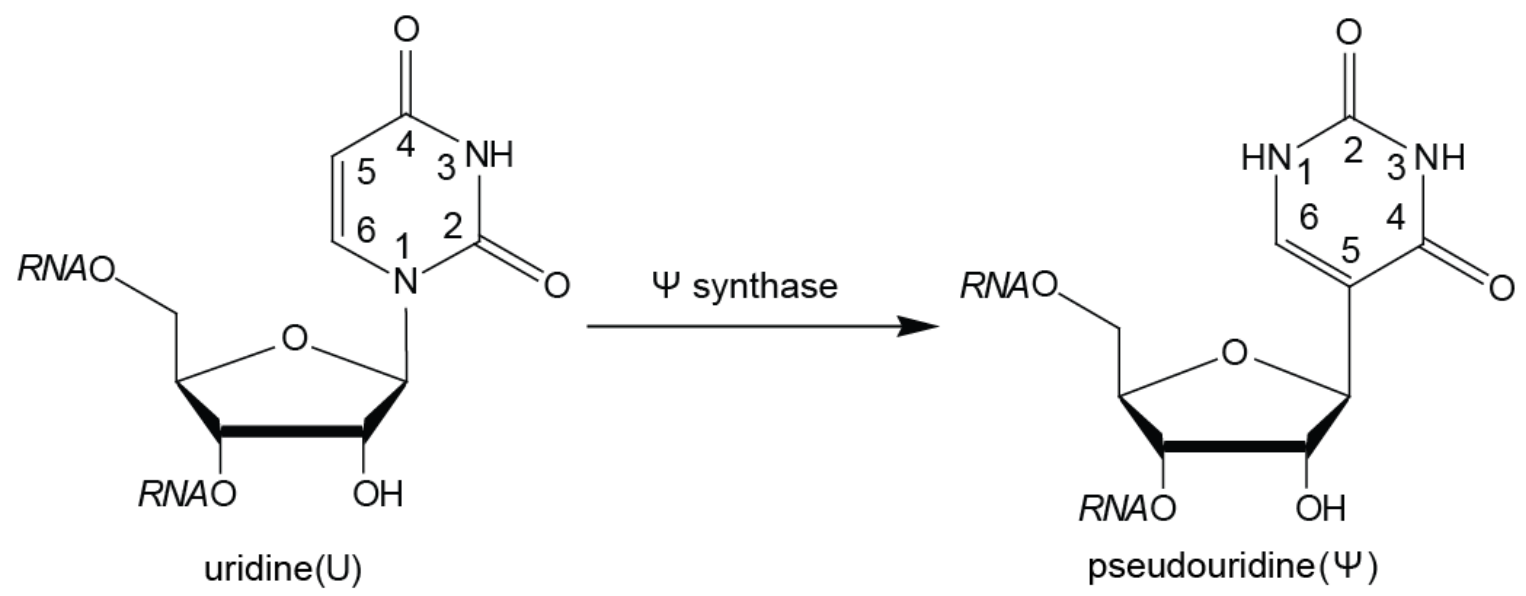

Figure 1.1: The isomerization of $U$ to $\Psi$ 
in polynucleotide chains provides an appropriate geometry for coordination of a water molecule between the imino proton and the 5'-phosphate backbone of its preceding residue, thereby restricting the base conformation and mobility of the backbone. [8] Additionally, $\Psi$ enhances local RNA stacking, which is perhaps the most important contribution of $\Psi$ towards stabilizing the RNA structure. [8]

The ubiquity of $\Psi$ across all forms of RNA emphasizes its physiological importance. Lack of $\Psi$ at positions 1911, 1915, and 1917 of 23 S rRNA in E. coli causes severe growth retardation. [9-11] In Thermus thermophilus, $\Psi 55$ in tRNA is essential for the low temperature adaptation of this extremophile. [12] Depletion of the $\Psi$ synthase encoded by minifly in Drosophila results in a severe reduction in the wing size by decreasing both the number and size of wing cells (due to cell death rather than reduced cell proliferation). [13] Mutations in the human gene dyskerin, an ortholog of the $\Psi$ synthase-encoding Cbf5 gene is shown to be associated with the $\mathrm{X}$-linked form of dyskeratosis congenita, a rare hematopoietic and malignant disorder. [14-16] Individuals with this disorder show increased cancer susceptibility, failure in ribosome biogenesis, and cells with decreased telomerase activity that results in a difficulty maintaining the telomere length. [1416] In humans, a single mutation in the PUS1 gene has been correlated with mitochondrial myopathy and sideroblastic anemia. [17] The tRNAs of patients with this affliction lack the $\Psi$ expected to be generated by Pus1p. [17]

\section{Pseudouridine synthases}

Based on sequence comparisons and structural analysis, six different families of $\Psi$ have been classified: TruA, TruB, RluA, RsuA, TruD and PUS10, 
which are named after the first cloned member of the family. $[18,19]$ Despite the lack of statistically significant global sequence similarity, a superimposition of the crystal structures of $\Psi$ synthases reveals a conserved core $\beta$-domain, strongly suggestive of divergent evolution. [20] Biochemical characterization revealed that $\Psi$ synthases do not require any cofactors for catalysis, nor do they release detectable amounts of uracil during the isomerization of $U$ to $\Psi$. [21-23] The $\Psi$ synthases share several amino acids conserved across all the families in both sequence and structure. The active site cleft of all six families shows an absolutely conserved aspartic acid residue (hereafter, the 'conserved Asp'), a conserved basic residue (Arg or Lys), and two aromatic residues (Phe or Tyr). Site-directed mutagenesis in a multitude of $\Psi$ synthases revealed the conserved Asp to be essential for enzyme activity. [9, 10, 24-27] In cocrystal structures of several $\Psi$ synthases with RNA, the conserved Asp lies in close proximity to the isomerized nucleotide, which supports direct participation in catalysis. [20]

$\Psi$ synthases recognize their substrate uridine in the context of an RNA, isomerizing certain positions in particular RNA (Figure 1.2) Except for Cbf5p and its orthologs, which function as a part of an elaborate ribonucleoprotein complex, all other $\Psi$ synthases characterized to date recognize their substrates without relying on accessory factors. [20]

Most of the mechanistic work reported in this dissertation is with the TruB family. TruB is responsible for the pseudouridylation of U55 in the $\underline{\mathbf{T}}$-arm stem loop (TSL) of all non-initiator tRNAs. [28] While some $\Psi$ synthases can only handle full length tRNA as a substrate, E. coli TruB and RluA handle small stem-loop 
substrates as well as the full-length tRNA. [29, 30] Santi and co-workers reported that the $K_{\text {cat }}$ and $K_{m}$ values for TruB and a 17-mer RNA oligonucleotide corresponding to the TSL of Saccharomyces cerevisiae tRNA ${ }^{\text {Phe }}$ were identical within error of the values with full-length tRNA. [29] Similar results were obtained by a predecessor in the Mueller group for RluA in a comparison of full-length E. coli tRNA ${ }^{\text {Phe }}$ and the 17-mer corresponding to its anticodon stem-loop (ASL). [30]

\section{Proposed mechanisms for $\Psi$ synthases}

\section{5-fluorouridine}

Previous mechanistic work with $\Psi$ synthases relied on site-directed mutagenesis and RNA containing 5-fluorouridine ([$\left.\left.F^{5} U\right] R N A\right)$ in the place of $U$ (Figure 1.3). 5Fluorouracil is a potent anti-cancer drug especially useful in treating colorectal cancer. [31] Early work by Frendewey et al. demonstrated the potent inhibitory action of tRNAs containing $F^{5} U$ on unfractionated tRNA $\Psi$ synthases. [32] In their work on thymidylate synthase, Santi and co-workers demonstrated that $F^{5} U$ gets converted into several intracellular active metabolites such as 5-fluorodeoxyuridine monophosphate ( $\left.\mathrm{F}^{5} \mathrm{dUMP}\right)$, which acts as an inhibitor of thymidylate synthase, the sole de novo source of thymidylate for DNA replication and repair. [31, 33, 34] They further showed that thymidylate synthase irreversibly forms a Michael adduct between the thiol group of an active site cysteine residue and $C 6$ of $F^{5} \mathrm{dUMP}$, thereby blocking the catalytic site. [34] 


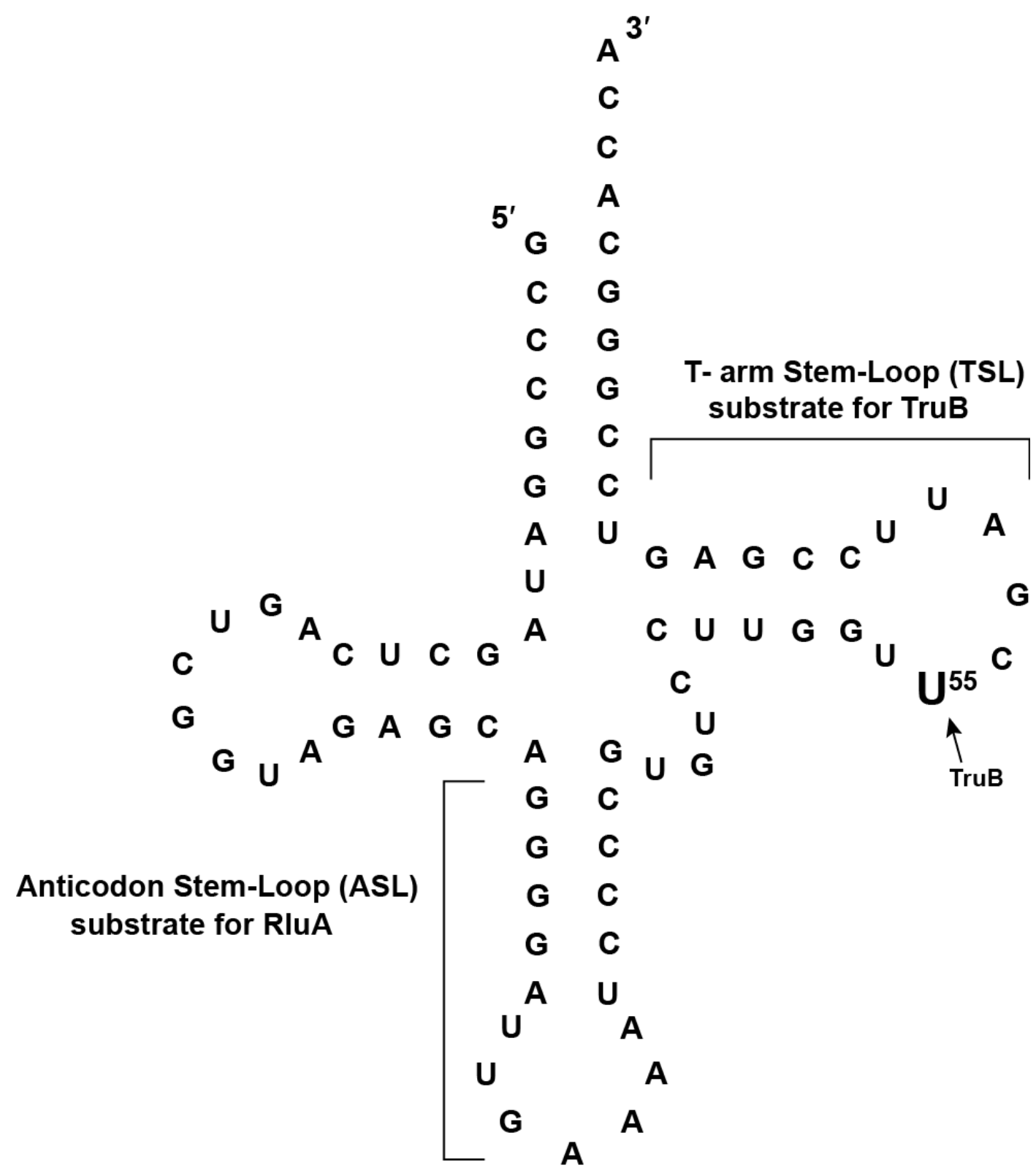

Figure 1.2: The classic 'cloverleaf' representation of $E$. coli tRNA Phe. The Iarm stem loop is the truncated substrate for TruB, which isomerizes U55. 
Inspired by this precedent, Penhoet and co-workers proposed a mechanism for $\Psi$ synthases in their report of the characterization of TruA. [35] They proposed a nucleophilic attack by an unidentified enzymic cysteine residue at $\mathrm{C} 6$ of $\mathrm{U}$ to form a dihydropyrimidine-enzyme adduct. Such an adduct was purported to 1) enhance the lability of $\mathrm{N}$-glycosidic bond, 2) provide an axis for the $180^{\circ}$ rotation of the pyrimidine ring to reposition $\mathrm{C} 5$ for $\mathrm{C}$-glycosidic bond formation, and 3) activate the proton on $\mathrm{C} 5$ of rearranged pyrimidine ring for subsequent $\beta$-elimination to give the product. [35] This proposed mechanism seemed to be supported by the observed inhibition of TruA upon incubation with sulfhydryl reagents.[35] To test this mechanistic premise, Santi and co-workers probed for the formation of covalent adduct for TruA by incubating it with full length [ $\left.\mathrm{F}^{5} \mathrm{U}\right] \mathrm{tRNA}$ transcripts. [29] SDS-PAGE and urea-PAGE analysis of the reaction mixture showed a slower moving protein-RNA adduct band on both gels. This putative covalent adduct band disappeared when the sample was heated, and mass spectrometric analysis of the RNA from heat-denatured adduct revealed that $\mathrm{F}^{5} \mathrm{U}$ in the RNA was hydrated [36] However, when one or all of the three cysteines in TruA were mutated, only a very modest decrease in the activity of TruA was observed. [37] Sequence alignments subsequently revealed that no cysteine residues were conserved and instead identified the conserved Asp, which became the candidate nucleophile. [29] These observations led Santi and co-workers to the reasonable conclusion that TruA proceeds through a mechanism (the 'Michael mechanism', Figure 1.4) analogous to that of thymidylate synthase and other methyl transferases with the exception that the conserved Asp acts as the nucleophile. [36] 
However, because of the lack of biochemical precedence for Asp acting as a Michael nucleophile, Santi and co-workers also proposed an alternative mechanistic scenario ('acylal mechanism', Figure 1.6) in which the conserved Asp nucleophilic attacks at $\mathrm{C} 1$ ' of $\mathrm{U}$ to form an acylal intermediate $[36,38]$ This scenario is well-precedented in retaining glycosidases. [39] The detached pyrimidine ring then rotates to reposition itself for the formation of bond between $\mathrm{C} 5$ and $\mathrm{C} 1^{\prime}$, and subsequent deprotonation of the $\mathrm{C} 5$ generates $\Psi$. However, because radiolabeling studies indicated that the pyrimidine ring of $\mathrm{F}^{5} \mathrm{U}$ was attached to the enzyme, Santi and co-workers favored the Michael mechanism over the acylal mechanism. [36]

\section{Cocrystal structure of TruB with $\left[\mathrm{F}^{5} \mathrm{U}\right] \mathrm{TSL}$}

Based on the presumption that TruB also follows the Michael mechanism and would be inhibited by [ $\left.\mathrm{F}^{5} \mathrm{U}\right] \mathrm{RNA}$, Hoang and Ferré-D'Amaré cocrystallized TruB with $\left[F^{5} U\right] T S L$, and they fully expected to see a covalent linkage between the enzyme and the RNA. However, a noncovalent complex was observed in which the hydrated $F^{5} U$ was rearranged to the $C$-glycoside isomer (Figure 1.5). [40] These observations led Hoang and Ferré-D'Amaré to conclude that TruB follows the Michael mechanism, but the reaction proceeds to the $C$-glycoside isomer. The failure to observe a covalent adduct in the cocrystal was ascribed to the slow ester hydrolysis of the rearranged Michael adduct that occurred over the course of crystal growth and diffraction analysis. [40]

Subsequent biochemical investigations by Spedaliere and Mueller, however, proved definitively that TruB neither gets inhibited by nor forms a stable adduct with [ $\left.\mathrm{F}^{5} \mathrm{U}\right] \mathrm{TSL}$. [25] Instead, TruB converts the $\mathrm{F}^{5} \mathrm{U}$ into its rearranged, 
A

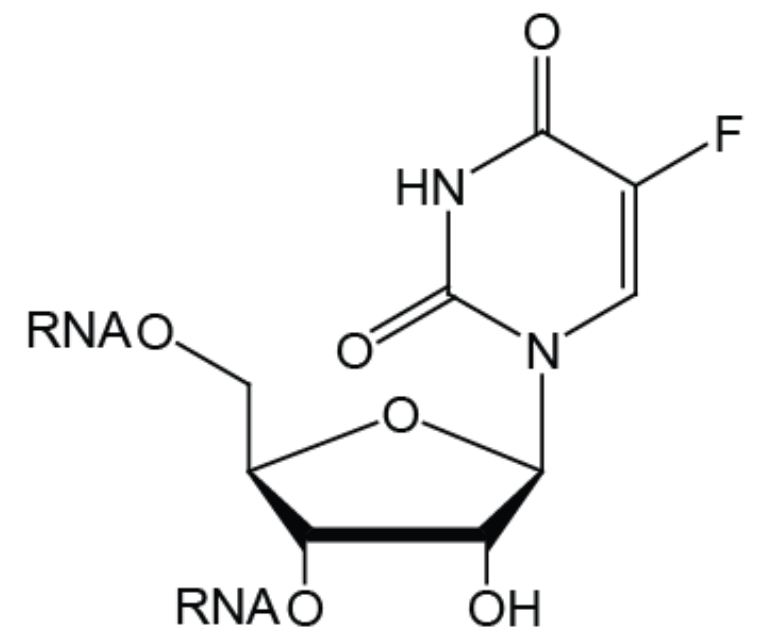

B

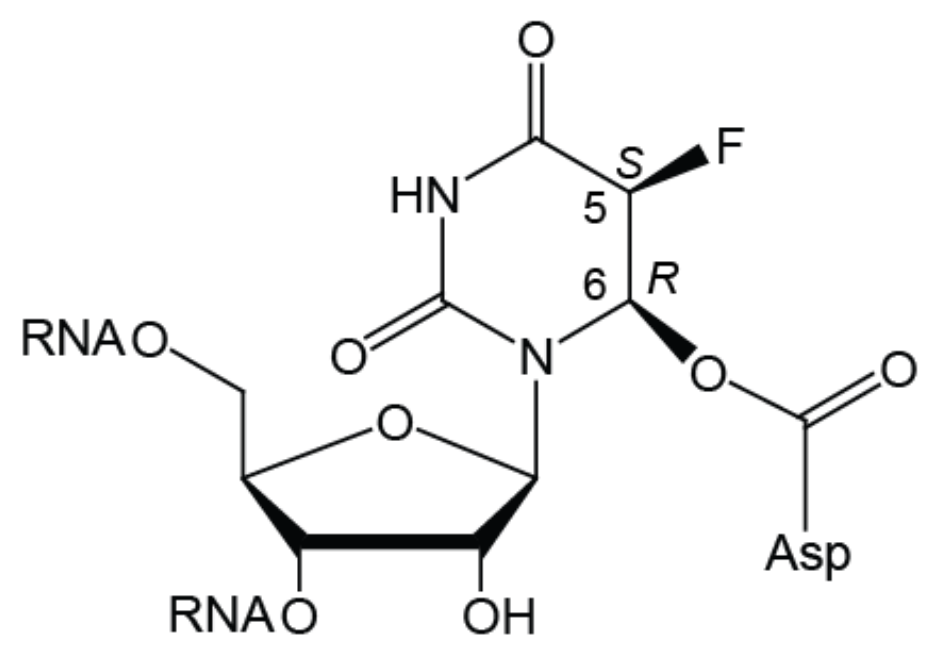

Figure 1.3: A, 5-fluorouridine. B, The Michael adduct between TruA and [F5]RNA proposed by Santi and co-workers. [29] 

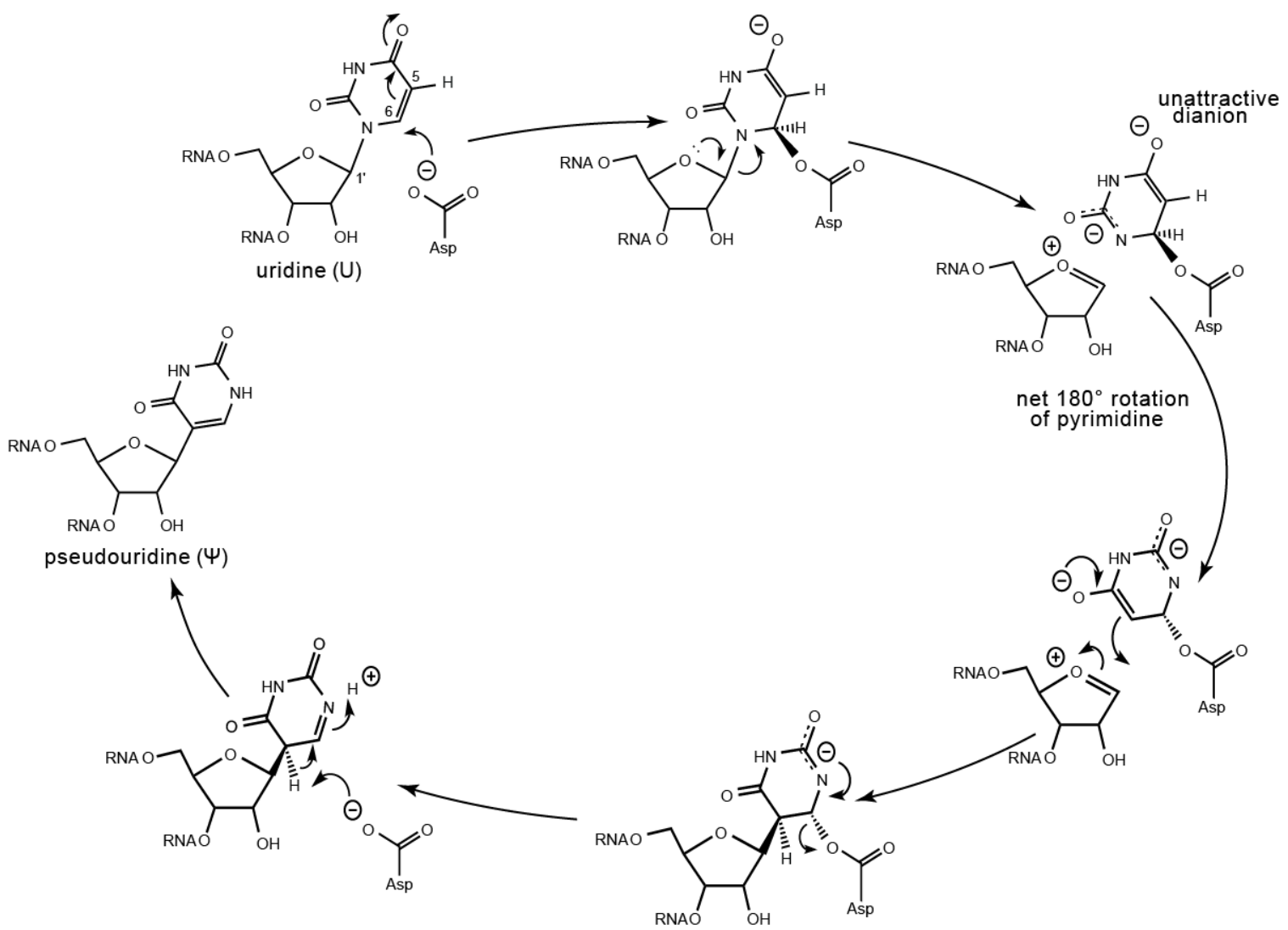

Figure 1.4: The proposed 'Michael mechanism' for $\Psi$ synthases. The conserved Asp makes a nucleophilic attack on $\mathrm{C} 6$ of the pyrimidine ring to form a Michael adduct. $\mathrm{N}$-glycosidic bond cleavage then occurs, and the pyrimidine ring makes a net $180^{\circ}$ rotation to reposition itself for the subsequent $\boldsymbol{C}$-glycosidic bond formation. Cleavage of the rearranged adduct followed by deprotonation at C5 completes the isomerization. 
A.

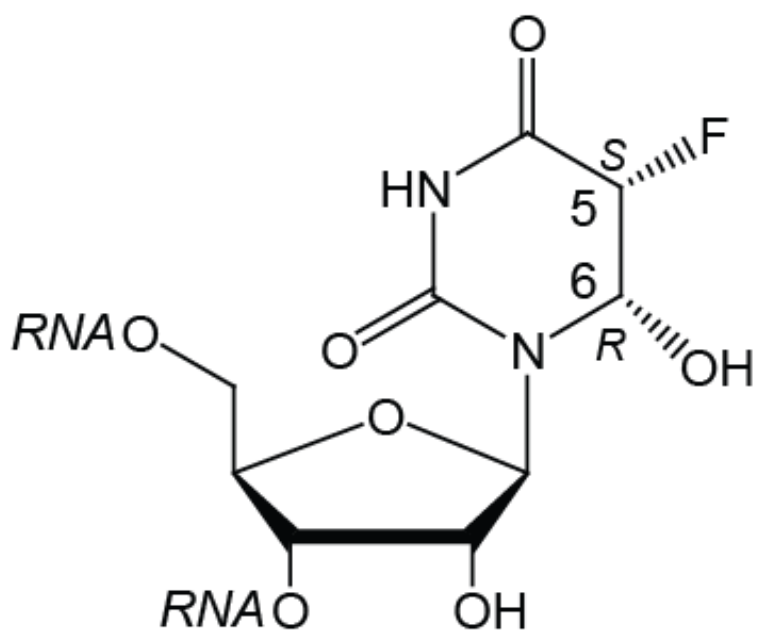

$B$.

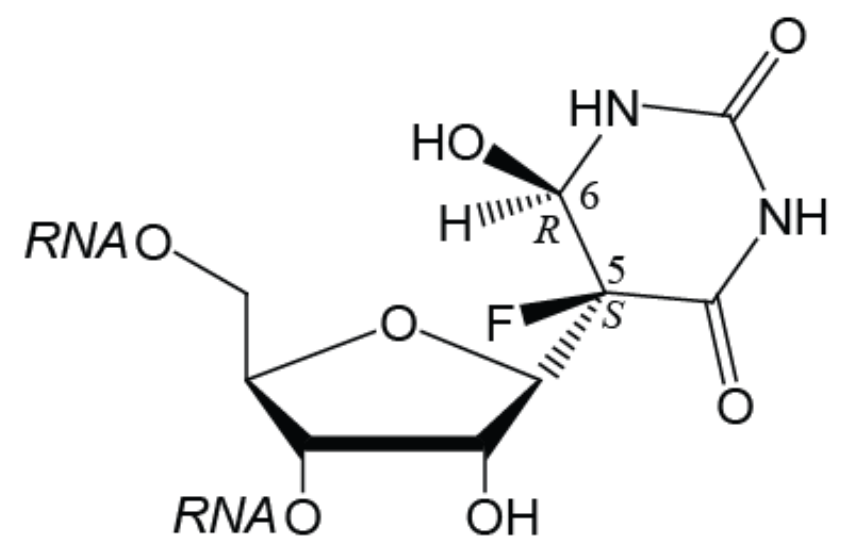

Figure 1.5: A, The hydrated product proposed by Santi and co-workers, cis(5S,6R)-6-hydroxy, 5, 6-dihydro-5-fluorouridine. [29] B, The hydrated rearranged product of $\mathrm{F}^{5} \mathrm{U}$ (cis-(5S,6R)-5-fluoro, 6-hydroxypseudouridine) observed by Hoang and Ferré D'Amaré in the cocrystal structure of TruB with [F5]TSL. [40] 


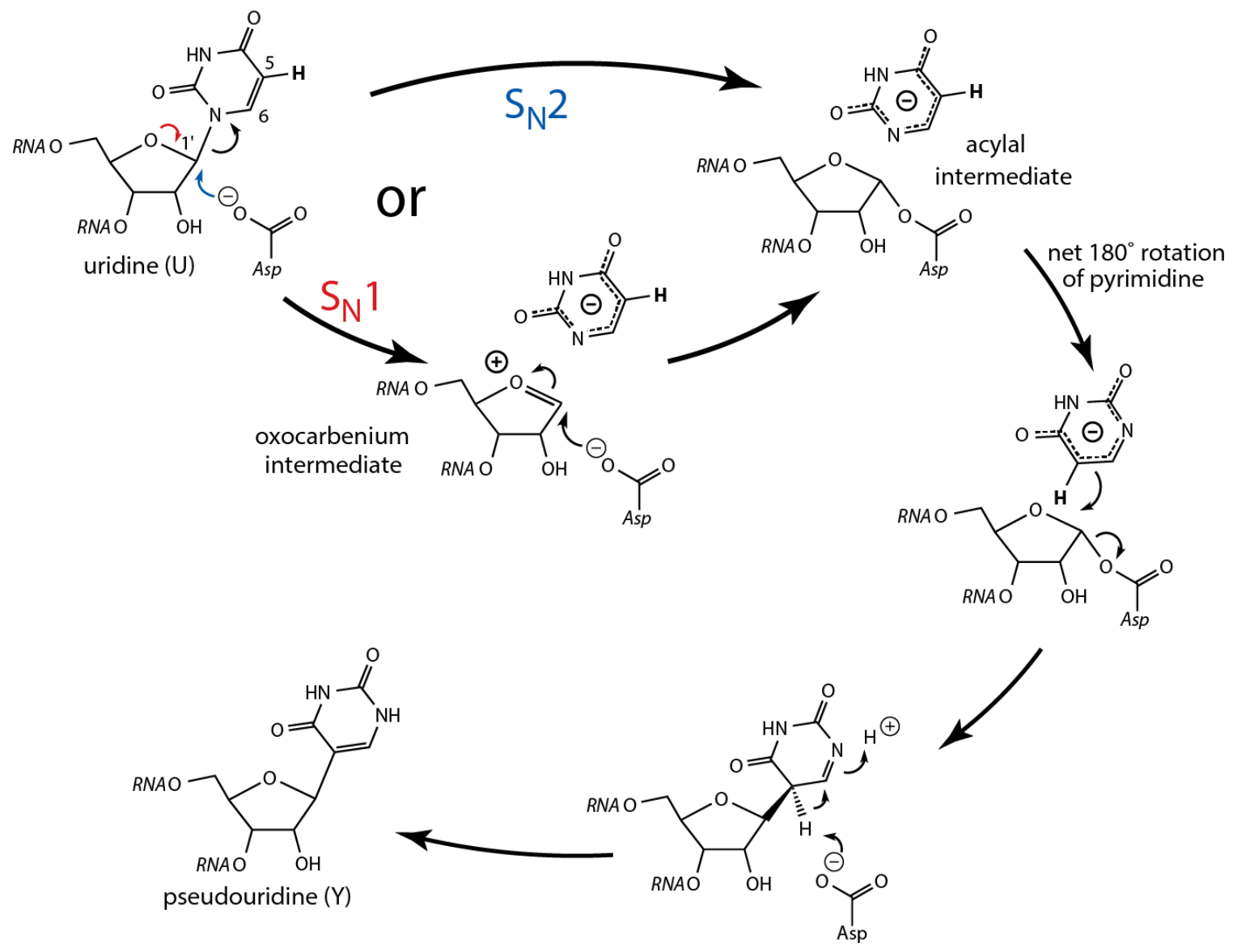

Figure 1.6: The 'acylal mechanism' for $\Psi$ formation, which begins with the conserved Asp making a nucleophilic attack on $\mathrm{C}^{\prime}$ ' of the ribose ring either through a concerted or step-wise process, thereby displacing the pyrimidine ring. After $\mathrm{N}$-glycosidic bond breakage, the uracilate anion makes a $180^{\circ}$ rotation for $C$-glycosidic bond formation 
hydrated $C$-glycoside isomer $\left(\mathrm{F}^{5} \mathrm{U}^{*}\right)$ in a time frame similar to the conversion of $\mathrm{U}$ to $\Psi$. Furthermore, HPLC analysis of the nucleotides resulting from treatment of the product RNA with $\mathrm{S} 1$ nuclease and alkaline phosphatase showed two more polar products of $\mathrm{F}^{5} \mathrm{U}$, which were shown to be hydrated by mass spectrometry. [25] Subsequent NMR experiments by Miracco and Mueller established that both $\mathrm{F}^{5} \mathrm{U}$ products were rearranged similarly to the one seen in the cocrystal structure of TruB with [ $\left.\mathrm{F}^{5} \mathrm{U}\right] \mathrm{RNA}$. [41]

\section{${ }^{18} \mathrm{O}$ labeling studies}

To elucidate the mechanism of the $\Psi$ synthases further, Spedaliere and Mueller conducted labeling experiments with TruB and $\left[\mathrm{F}^{5} \mathrm{U}\right] \mathrm{TSL}$ in $\left[{ }^{18} \mathrm{O}\right]$ water. [42] If the mechanism were to proceed through the formation of a Michael adduct and heating the adduct did indeed lead to the proposed ester hydrolysis, then running the reaction in $\left[{ }^{18} \mathrm{O}\right]$ water would result in the incorporation of ${ }^{18} \mathrm{O}$ label into the conserved Asp (Figure 1.7). Instead, the label ended in RNA, ruling out ester hydrolysis. [42] The same result held for RluA and TruA. [30, 41] These observations led Mueller and co-workers to propose a scheme to account for the handling of $\mathrm{F}^{5} \mathrm{U}$ by all $\Psi$ synthases (Figure 1.8). The $\Psi$ synthase reaction proceeds through either the Michael or acylal to rearranged $\mathrm{F}^{5} \mathrm{U}$, and idiosyncracies of the active site dictate its fate. In some active sites (TruA and RluA, for example), the conserved Asp can reach C6 and make a stable adduct whether it had previously been formed (Michael mechanism) or not (acylal mechanism). In this case, the stable covalent adduct between the conserved Asp and [ $\left.\mathrm{F}^{5} \mathrm{U}\right] \mathrm{RNA}$ undergoes elimination (rather than ester hydrolysis) upon heating, followed by spontaneous 
hydration of the rearranged $\mathrm{F}^{5} \mathrm{U}$ in solution. $[30,41]$ In other active sites (TruB, for example), the conserved Asp does not form a stable adduct with the pyrimidine, so the rearranged $\mathrm{F}^{5} \mathrm{U}$ is simply released into solution followed by hydration.

\section{Identity of the products of $F^{5} \mathrm{U}$}

The definitive structural elucidation of the two $\mathrm{F}^{5} \mathrm{U}$ products of TruB was undertaken to provide further mechanistic insight. After isolating the $\mathrm{F}^{5} \mathrm{U}^{*}$ from the action of both TruB and RluA on a suitably large scale, Miracco and Mueller used a myriad of NMR experiments to establish the identity of the products. [43] Their NMR studies revealed that both of the isolated products were dinucleotides (Figure 1.9), [41] which explained an apparent discrepancy in the HPLC behavior for the $\mathrm{F}^{5} \mathrm{U}$ products formed by the reaction of TruB and RluA. [41] The products from the action of TruB had different retention times than the single peak resulting from the action of RluA. Since the RNA substrates differ in the nucleoside following the isomerized $\mathrm{U}$, the different retention times were immediately explained. The single peak for the products of $\mathrm{F}^{5} \mathrm{U}$ from RluA action were simply not resolved by the HPLC conditions. The maintenance of an approximately $3: 1$ ratio of the two products of $\mathrm{F}^{5} \mathrm{U}$ through the process of enzymatic digestion, isolation, and storage strongly suggested that the two products differed by stereochemical rather than conformational isomerism. [43] 
$A$

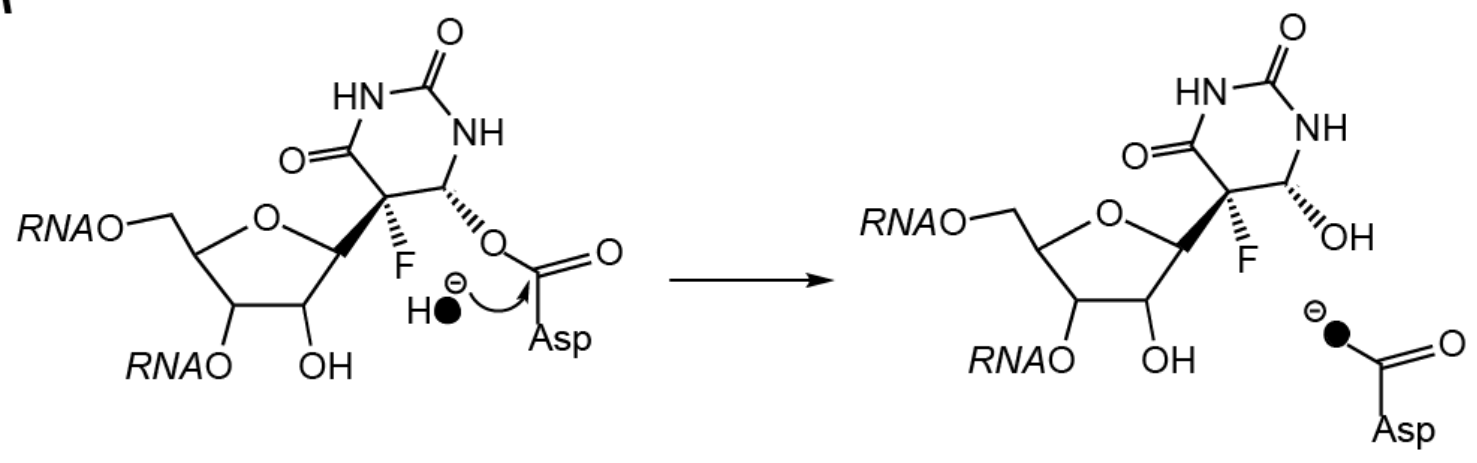

$B$

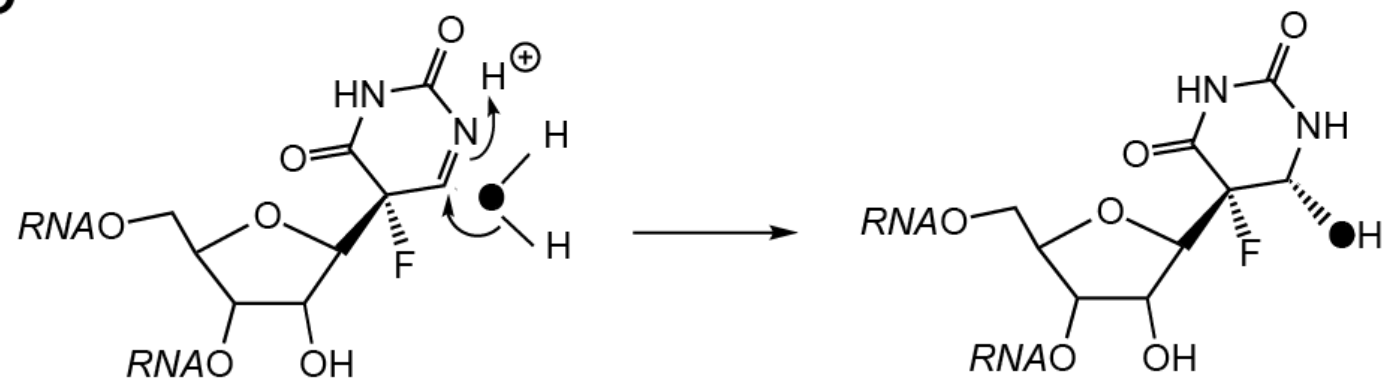

Figure 1.7: ${ }^{18} \mathrm{O}$ labeling scheme. A, Ester hydrolysis would result in ${ }^{18} \mathrm{O}$ incorporation into the conserved Asp. B, Direct hydration of the rearranged product of $F^{5} U$ results in labeled $F^{5} U^{*}$. 


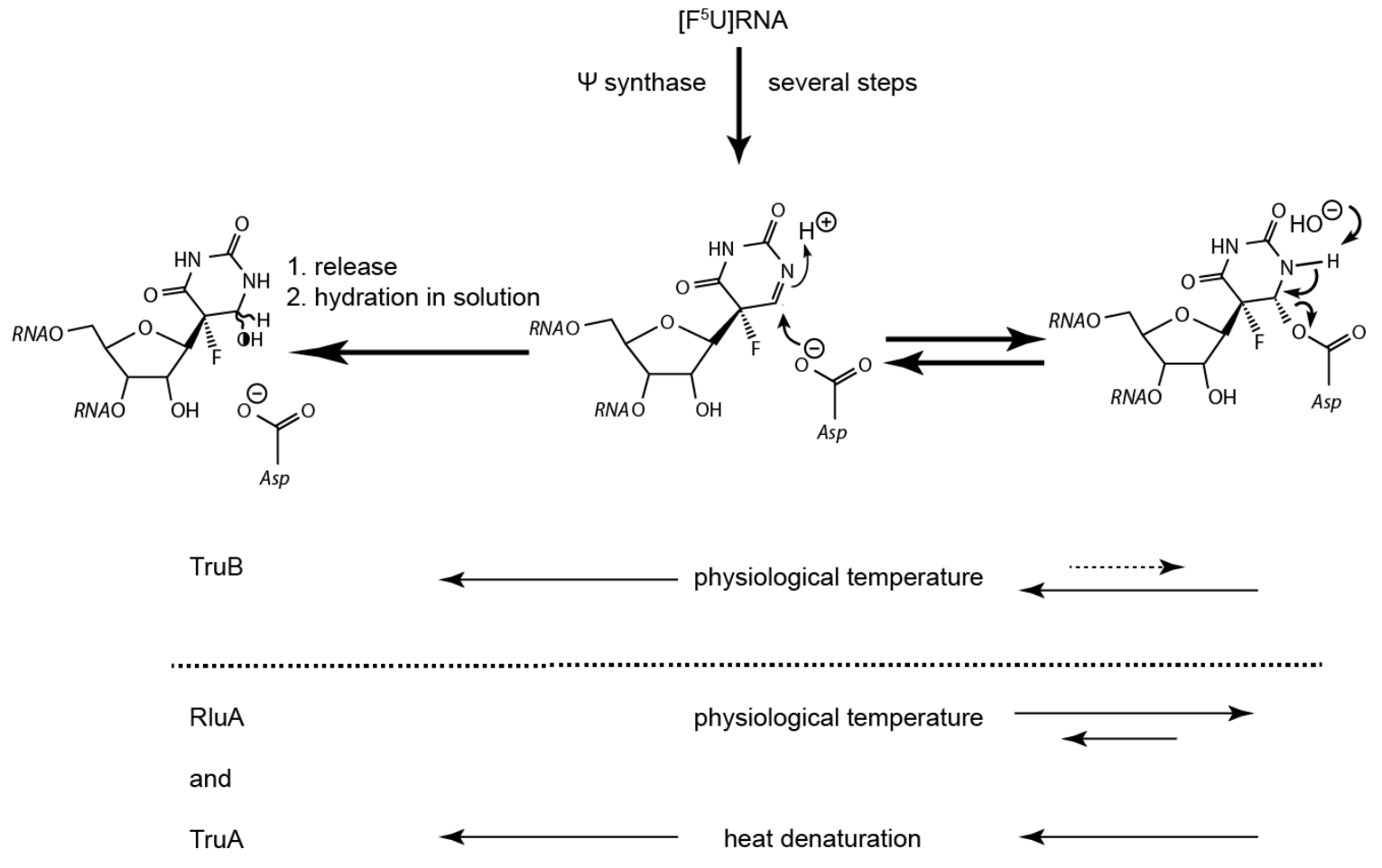

Figure 1.8: The proposed consistent scheme for the handling of $F^{5} U$ in RNA by different $\Psi$ synthases. [41] 
The major product was confirmed as the one seen in the cocrystal structure of TruB with $\left[F^{5} U\right] T S L$. $[40,43]$ The minor product proved even more interesting. First, when comparing the chemical shifts of sugar protons in the two products, $\mathrm{H}^{2}$ and C2' of the minor product were deshielded, an indication that the minor product differs from major product at $\mathrm{C}^{\prime}$ of ribose rather than $\mathrm{C} 6$ of the pyrimidine ring. [43] Second, ${ }^{1} \mathrm{H}-{ }^{1} \mathrm{H}$ Nuclear Overhauser Effect experiments (NOE) showed a strong correlation between $\mathrm{H}^{2^{\prime}}$ and $\mathrm{H}^{5^{\prime}} / \mathrm{H}^{5^{\prime \prime}}$ for the major product that was absent in the minor product, a result which indicated greater separation between $\mathrm{H}^{2 \prime}$ and $\mathrm{H}^{5^{\prime}} / \mathrm{H}^{5^{\prime \prime}}$ in the minor product. [43] Third, the strong NOE seen between $\mathrm{F}^{5}$ and $\mathrm{H}^{2^{\prime}}$ in the major product was absent in the minor product, and the minor product also lacked a detectable NOE between $\mathrm{H}^{2}$ and $\mathrm{H}^{6}$ for minor product that was observed in the major product. [43] These findings along with residual dipolar coupling experiments and density functional theory calculations established the identity of the minor product to be the arabino isomer whereas the major product was the ribo isomer. These two products, then, differ in stereochemistry at C2' (Figure 1.9). For the arabino product to form, epimerization at $\mathrm{C}^{\prime}$ must occur, which requires deprotonation of C2' to form a glycal intermediate followed by reprotonation of C2' on the opposite face. [43] 


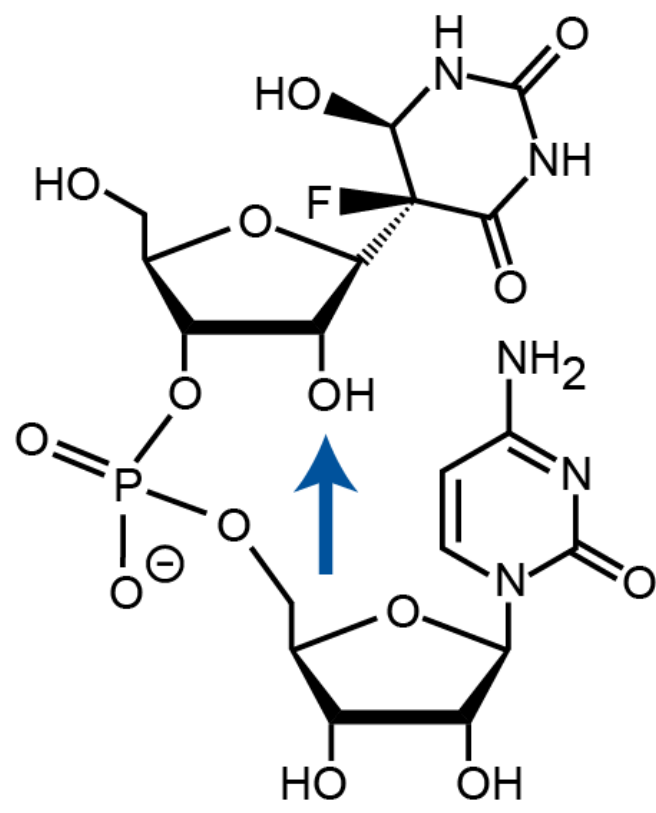

major product: ribo

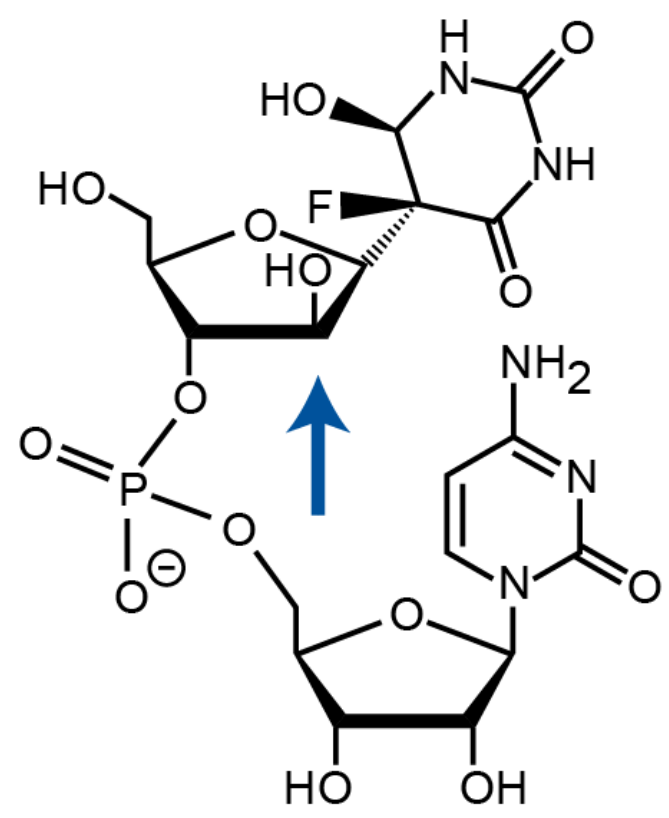

minor product: arabino

Figure 1.9: The major and minor products of $\mathrm{F}^{5} \mathrm{U}^{*}$ differ in stereo configuration of C2'. [43] 


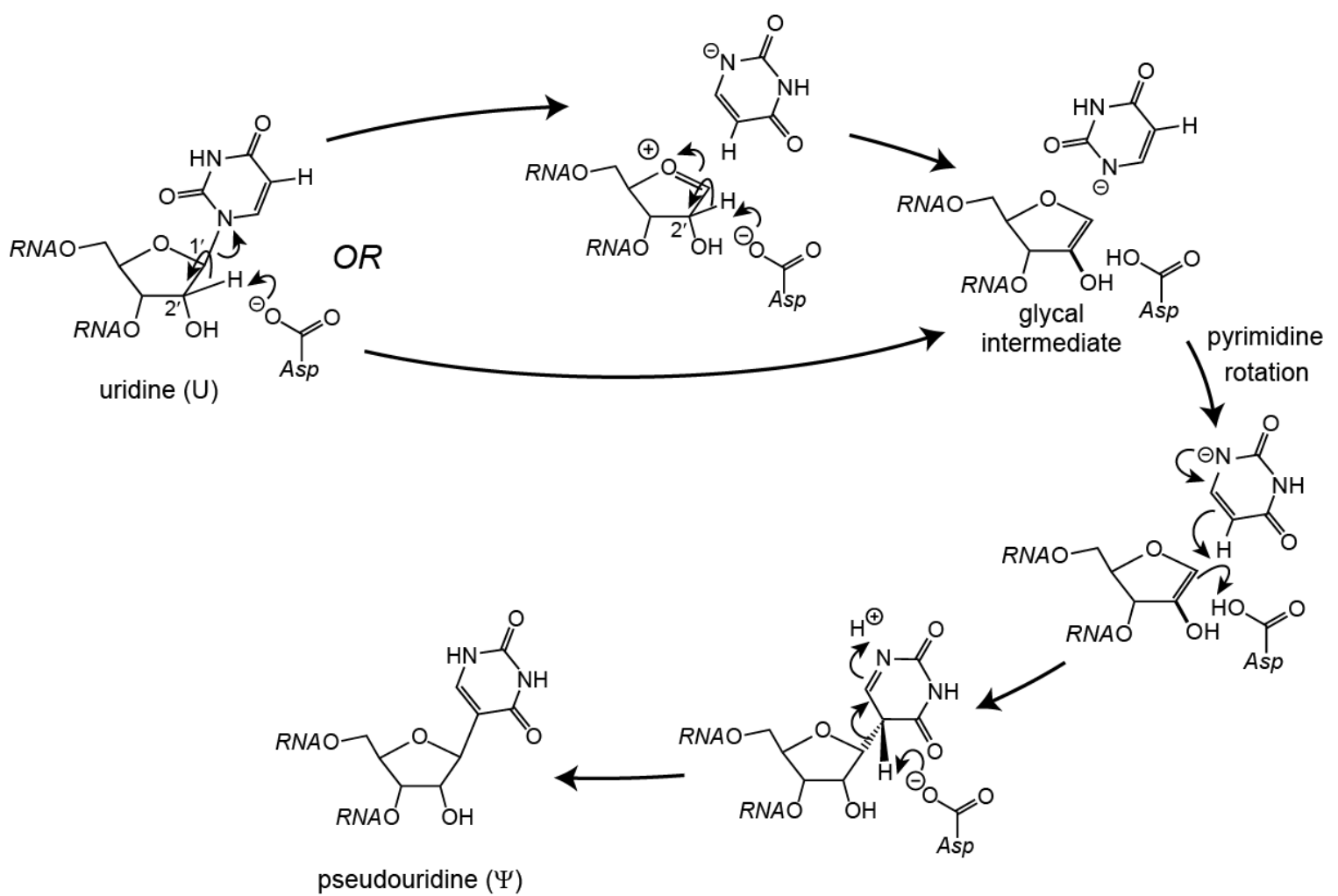

Figure 1.10: The "glycal mechanism" for $\Psi$ formation. The conserved Asp initiates the reaction by deprotonating C2' which leads to a glycal intermediate. After the $C$-glycoside rearrangement, $\mathrm{C2}^{\prime}$ is reprotonated by the conserved Asp. 


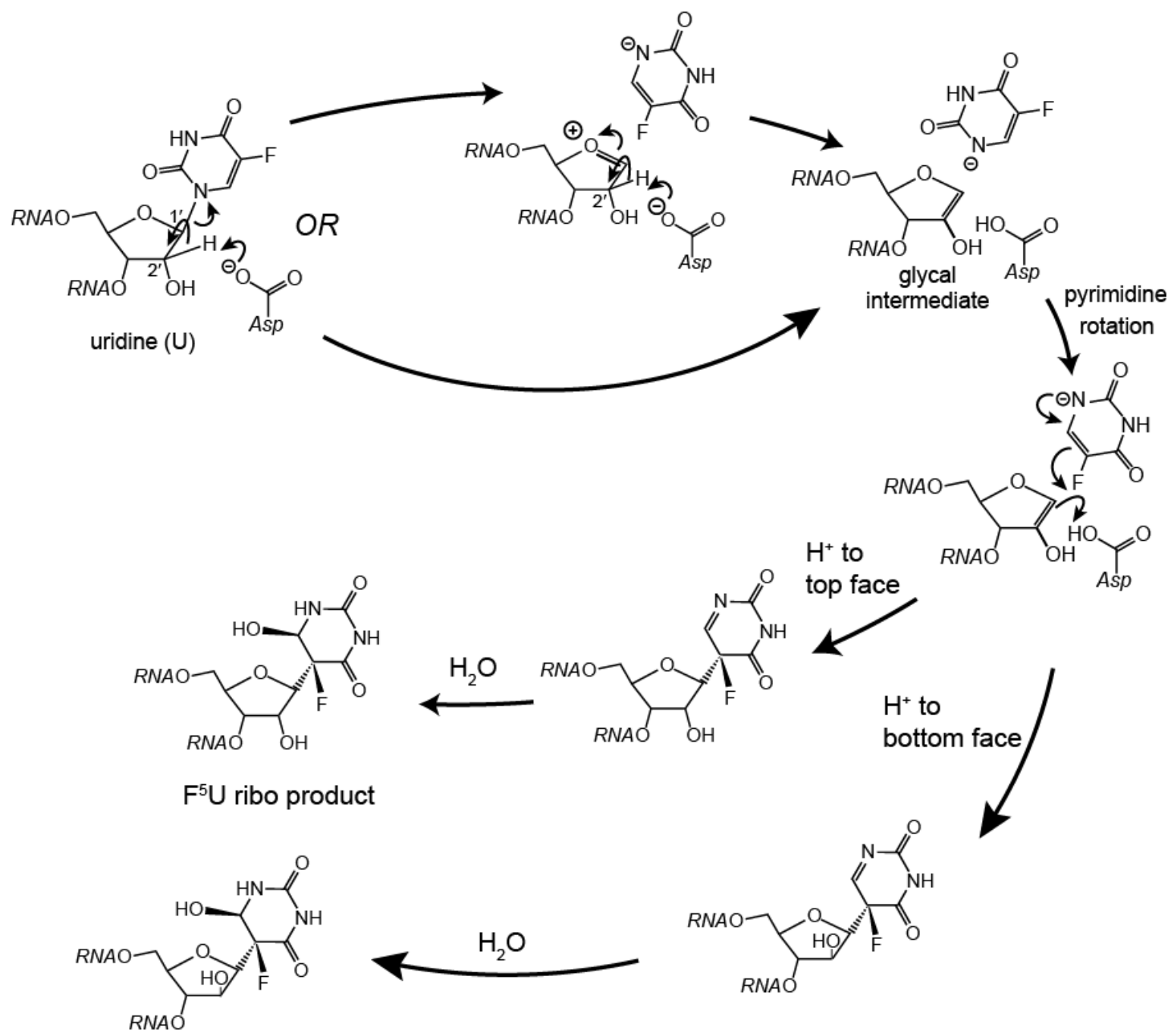

$\mathrm{F}^{5} \mathrm{U}$ arabino product

Figure 1.11: The "glycal mechanism" with $F^{5} U$. Reprotonation from the "bottom" face of the glycal ring results in the observed arabino product of $F^{5}$ U. [43] 


\section{Implications of a glycal intermediate}

If a glycal intermediate exists along the reaction pathway, a new mechanistic possibility emerges, the 'glycal' mechanism. (Figure 1.10) Uridine phosphorylase offers a biochemical precedent for glycal intermediate formation in enzymes. [44] Deprotonation of the C2', followed by reprotonation from the "bottom" face would explain the observed arabino $\mathrm{F}^{5} \mathrm{U}$ product (Figure 1.11). The acylal mechanism can also account for the formation of an arabino product of $\mathrm{F}^{5} \mathrm{U}$. The decreased nucleophilicity of the 5 -fluorouracilate anion effectively increases the lifetime of the acylal intermediate, which is in equilibrium with the oxocarbenium species and the free conserved Asp. The increase in acidity of C2' in the oxocarbenium species facilitates its deprotonation by the conserved Asp to give the glycal intermediate. In such case, reprotonation of the glycal intermediate from the "bottom" face results in an arabino product (Figure 1.12). [43]

Because the conserved Asp is the only acidic group in proximity to the sugar ring to effect reprotonation of C2' from the "bottom", the arabino product strongly disfavors the Michael mechanism, for the conserved Asp is tied up in an ester bond at the critical time. The alternative protonation directly by solvent (specific rather than general acid catalysis) was ruled out by running the $\Psi$ synthase reaction with [F5]RNA in buffer made with deuterated water ${ }^{1}$. [45] However, prior to the findings by Miracco and Mueller that led to the proposal of glycal mechanism, the glycal mechanism was still favored by many. To probe whether the Michael mechanism

\footnotetext{
${ }^{1}$ This result also rules out exchange of the proton on the enzymic general acid with solvent in the time frame of the reaction.
} 


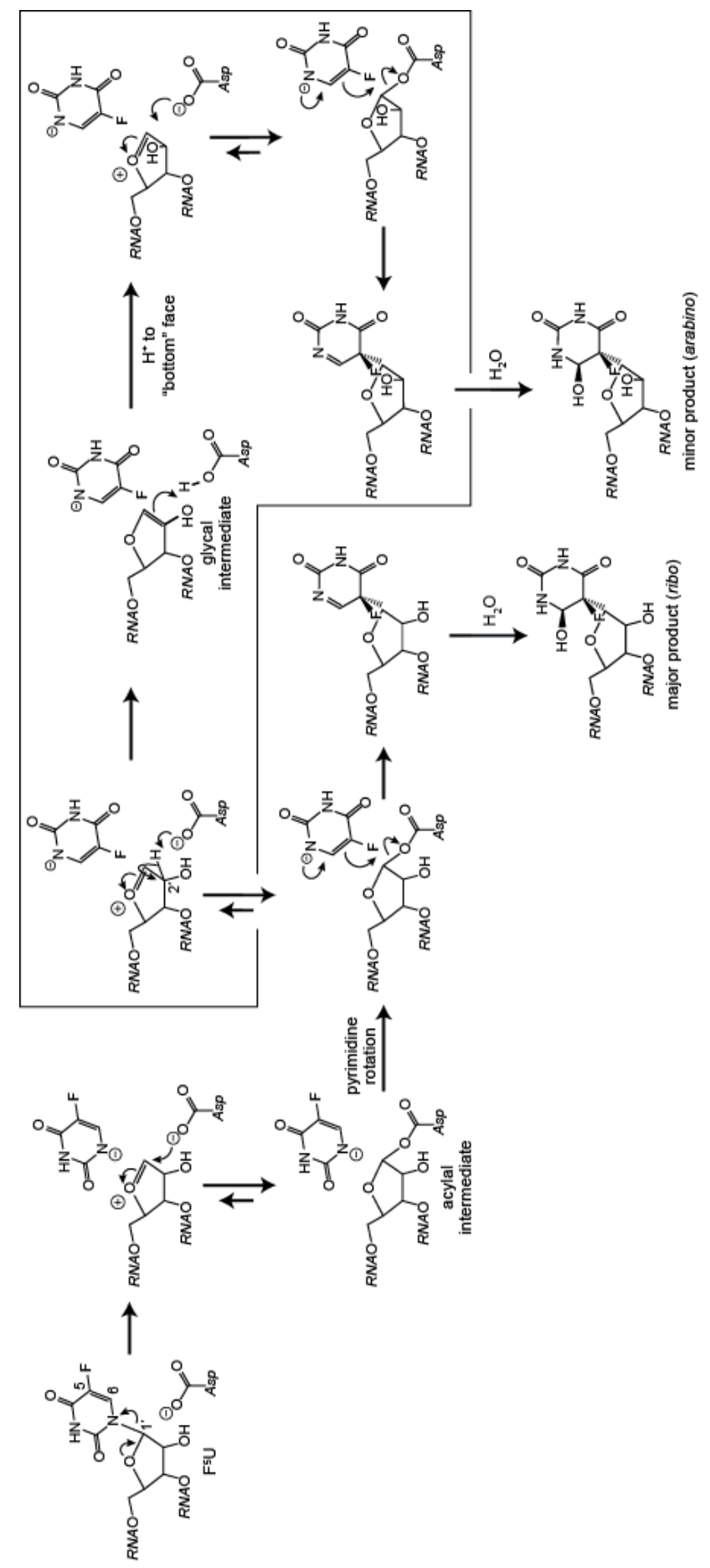

Figure 1.12: The acylal mechanism recast to emphasize features that can account for the arabino product of $F^{5} \mathrm{U}$. The boxed manifold exists only for $F^{5} U$ because of the increased life time of the oxocarbenium ion that is in equilibrium with the acylal intermediate. [43] 
in some form can still accommodate the glycal intermediate, additional mechanistic possibilities were considered. Such considerations in the context of recently published results [46] are presented in the next few sections of this chapter.

\section{Cocrystal structure of RluB with [F5]RNA}

While the existence of arabino product of $\mathrm{F}^{5} \mathrm{U}$ strongly argues against the Michael mechanism, others continue to champion it. Among them are Stroud and co-workers, who recently reported a cocrystal structure of RluB with [ $\left.F^{5} U\right] R N A$ that shows a covalent linkage between C6 of the pyrimidine ring and Tyr-140 (Figure 1.13). [46] Although a covalent adduct with Tyr does not provide direct evidence for the formation of a Michael adduct by the conserved Asp, Stroud and co-workers proposed a 'modified' Michael mechanism (Figure 1.14) that is essentially the 'consistent scheme' (Figure 1.15) grafted on to the Michael mechanism. The conserved Asp forms a Michael adduct, followed by rearrangement of $U$ to the C-glycoside isomer. The conserved Asp then undergoes elimination to yield the reactive intermediate, which in case of $\left[\mathrm{F}^{5} \mathrm{U}\right] \mathrm{RNA}$ either gets hydrated (in the cocrystals of TruB and RluA with [ $\left.\mathrm{F}^{5} \mathrm{U}\right] \mathrm{RNA}$ ) or forms a covalent adduct with Tyr140 (in the case of RluB). (Figure 1.13)

The mechanism proposed by Stroud and co-workers is based on the assumption that the conserved Asp initially forms a covalent adduct with the pyrimidine ring of [F5]RNA. [46] However, no evidence directly identifies the conserved Asp as the nucleophile that forms the Michael adduct. Although substitution of the conserved Asp abrogates adduct formation, it may be required for the generation of a reactive intermediate rather than direct participation in the 


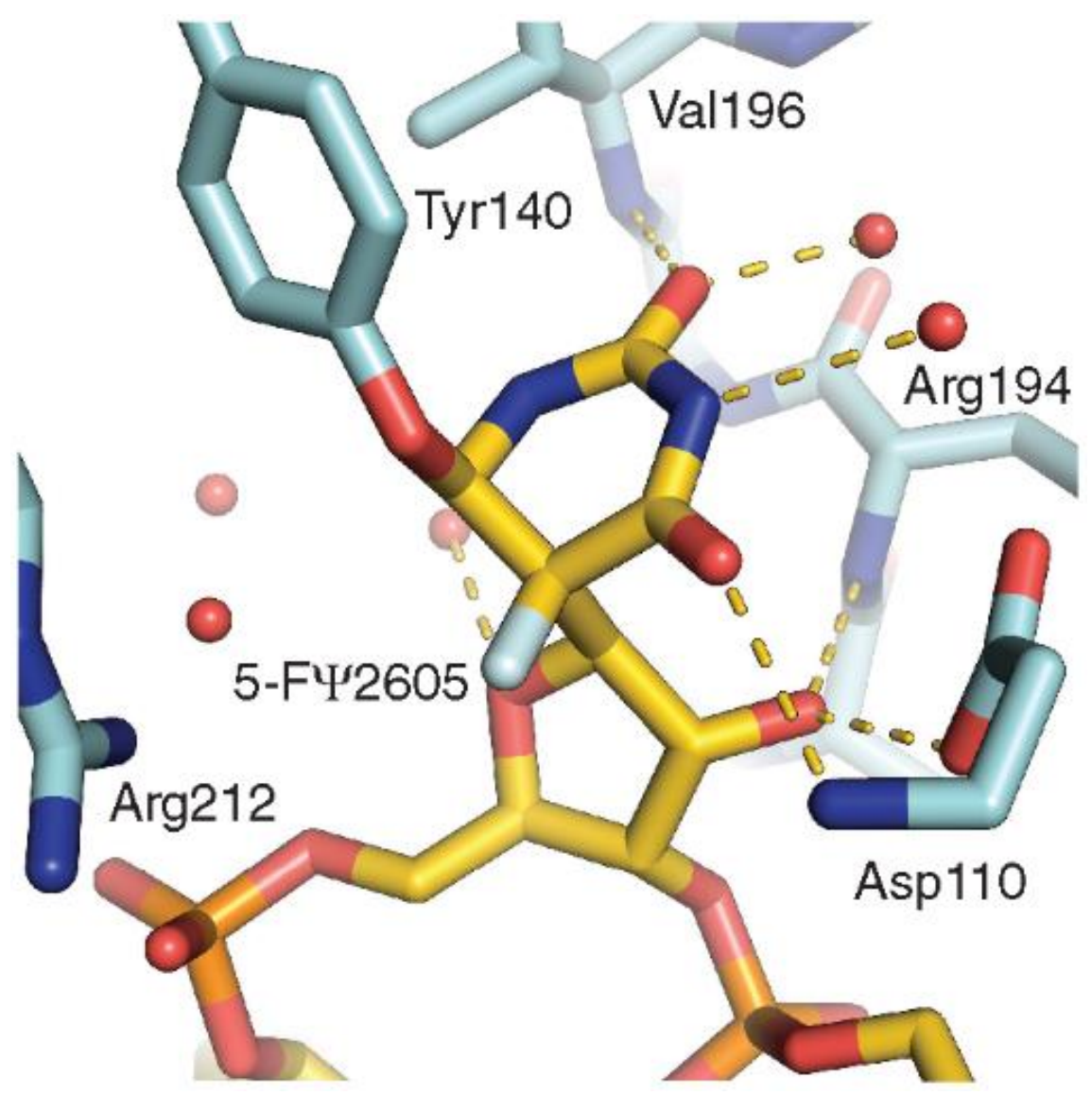

Figure 1.13: A close up view of the active site from the cocrystal structure of RluB and [ $\left.\mathrm{F}^{5} \mathrm{U}\right] \mathrm{RNA}$ reported by Stroud and co-workers. A covalent linkage can be seen between the Tyr-140 and $C 6$ of the pyrimidine ring of [F5]RNA. From ref 46. 

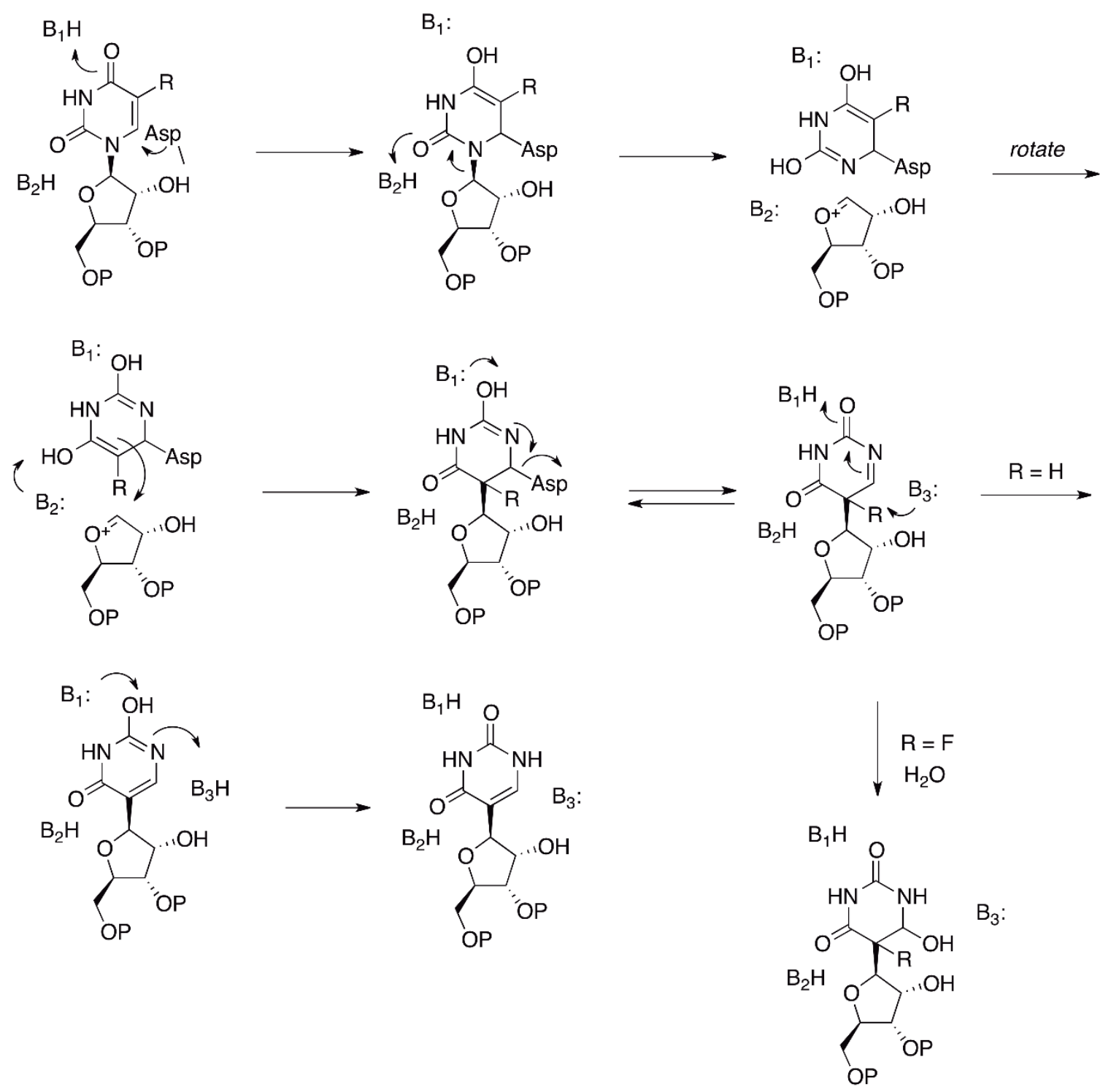

Figure 1.14: The modified Michael mechanism proposed by Stroud and co-workers. The conserved Asp initially forms a covalent adduct with the C6 of the pyrimidine ring. After rearrangement to the $C$-glycoside, the conserved Asp undergoes elimination. In the case of [ $\left.F^{5} U\right] R N A$, the $F^{5} U$ gets hydrated in solution or, in the case of RluB, forms a covalent adduct with Tyr-140. [46] 
adduct. The modified Michael mechanism also fails to explain the observed arabino product of $\mathrm{F}^{5} \mathrm{U}$, which requires epimerization at the $\mathrm{C}^{\prime}$ of the ribose ring. [43]

The consistent scheme proposed by the Mueller group, on the other hand, still accounts for all observations (Figure 1.15). The $\Psi$ synthases proceed through either the glycal mechanism or the acylal mechanism (re-cast in the wake of arabino product) to rearranged $\mathrm{F}^{5} \mathrm{U}$. In the case of RluB, instead of release into solution and spontaneous hydration, the phenolic $-\mathrm{OH}$ of Tyr-140 attacks at $\mathrm{C} 6$ of the pyrimidine ring to form the observed covalent adduct, which occurs because the idiosyncracies of the RluB active site allow formation of a stable adduct with Tyr-140. This scenario is supported by the results with Thermotoga maritima TruB.

\section{The interesting case of Thermotoga maritima TruB (TmTruB)}

In an attempt to obtain a covalent adduct of TruB, Huang and co-workers incubated TruB from four different organisms with $\left[\mathrm{F}^{5} \mathrm{U}\right] \mathrm{RNA}$, and T. maritima TruB (TmTruB) formed a covalent adduct as judged by the appearance of a shifted band on an SDS-PAGE gel (Figure 1.16); heat treatment disrupted the adduct. [47] No such adducts were seen with TruB from E. coli (EcTruB), B. subtilis, or $S$. cerevisiae. [47] However, the cocrystal structure of TmTruB with [F5] showed a noncovalent adduct identical to the one seen in case of EcTruB with [F5U]TSL. [40, 47] This seemingly disparate behavior made TmTruB an intriguing candidate for further characterization. These studies are described in Chapter 2 of this dissertation. 


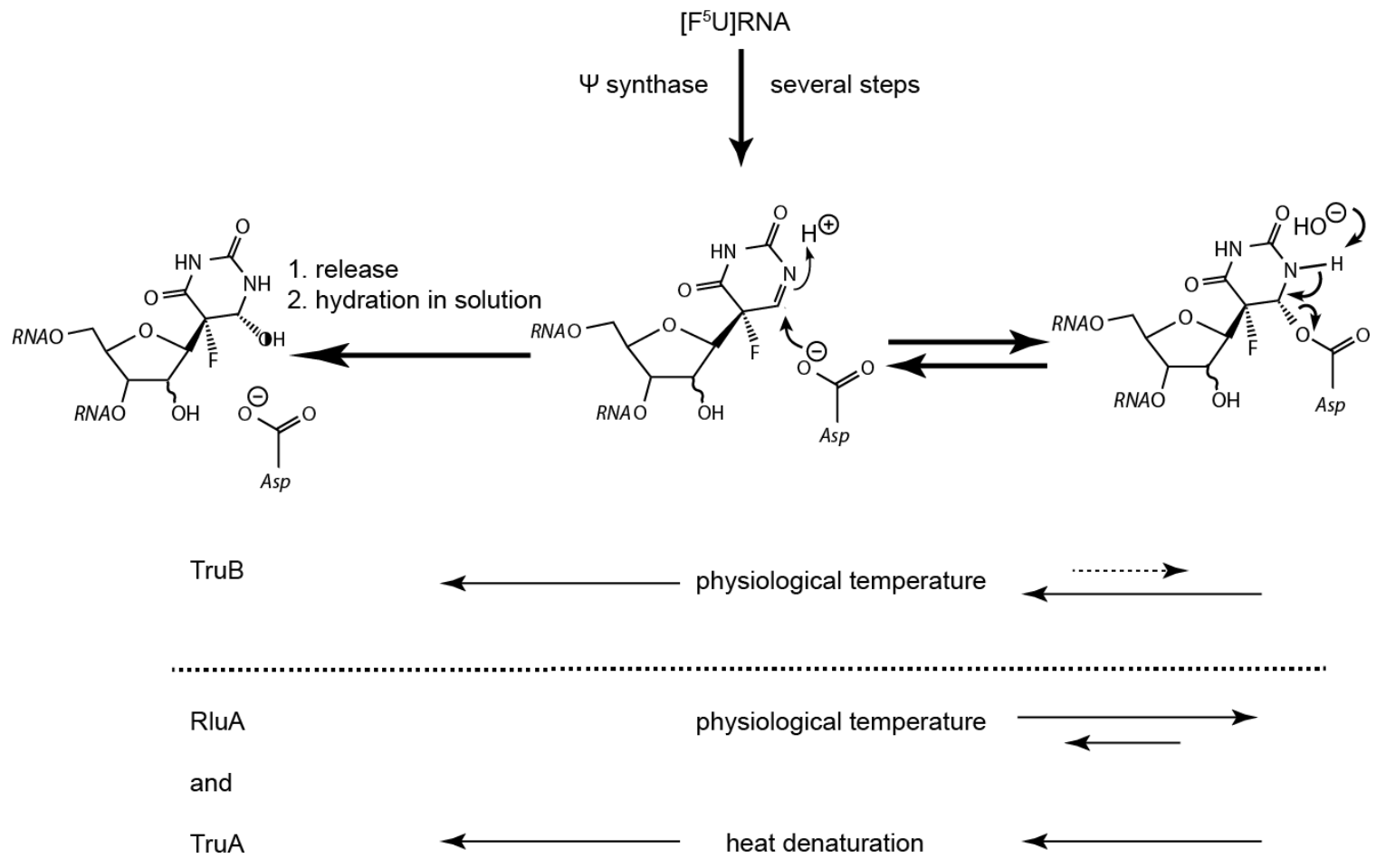

Figure 1.15: The consistent scheme proposed by Mueller and co-workers with mild revision to account for the arabino product of $\mathrm{F}^{5} \mathrm{U}$ and trapping by Tyr-140 of RluB. 


\section{The possibility of an active site Tyr forming the Michael adduct}

One other scenario that could accommodate a catalytic Michael adduct and the epimerization at $\mathrm{C2}^{\prime}$ would be another nucleophile to form the initial Michael adduct which would leave the conserved Asp free for the deprotonation/reprotonation of C2'. The $\Psi$ synthases show a conserved aromatic amino acid residue, which is a Tyr in five of the six families (it is the tyrosine seen in adduction with [ $\left.\mathrm{F}^{5} \mathrm{U}\right] \mathrm{RNA}$ in the RluB cocrystal). However, several lines of evidence argues against the role of Tyr forming a Michael adduct. The fully functional TruD family has nucleophilically incapable Phe residues in this conserved position. [48-50] Additionally, Huang and co-workers have reported that Y76F, Y76L, and Y76A TruB were inactive towards the natural substrate (with $\mathrm{U}$ ) but do handle [F5]RNA to generate rearranged, hydrated products of $F^{5} U$. [51] If the mechanism proceeds by the forming an initial Michael adduct between Tyr and the pyrimidine ring, the Tyr variants should have left both $U$ and $F^{5} U$ unchanged (if the adduct does not form, rearrangement to the $C$-glycoside should not occur). Finally, the $\mathrm{pH}$ profile studies on TruB by Mueller and co-workers suggest that the active site tyrosine residue functions in its protonated form to assist $\mathrm{N}$-glycosidic bond cleavage of the uridine, presumably by donating either a proton or hydrogen bond to the pyrimidine ring. $[26,52]$ In either scenario for the active site tyrosine residue, the $\mathrm{N}$-glycosidic bond cleavage of $\mathrm{F}^{5} \mathrm{U}$ does not require the assistance of Tyr because the inductive effect of fluorine makes its anion a better leaving group than the anion of uracil. 
An arabino product of $\mathrm{F}^{5} \mathrm{U}$ must arise from epimerization at $\mathrm{C}^{\prime}$ after its deprotonation. To probe whether the $\mathrm{C}^{\prime}$ is deprotonated during the course of the reaction with natural substrate and thus test the operation of the glycal mechanism, stem-loop substrates labeled with deuterium at the $\mathrm{C}^{2}$ position of $U$ were prepared and their rate of reaction compared to those of unlabeled substrates. If the glycal mechanism operates and either deprotonation or reprotonation of $\mathrm{C2}^{\prime}$ is at least partially rate-limiting, replacement of proton on C2' with deuterium should result in a primary kinetic isotope effect and provide definitive evidence for glycal formation. This work constitutes Chapter 4 of this dissertation. 
A.

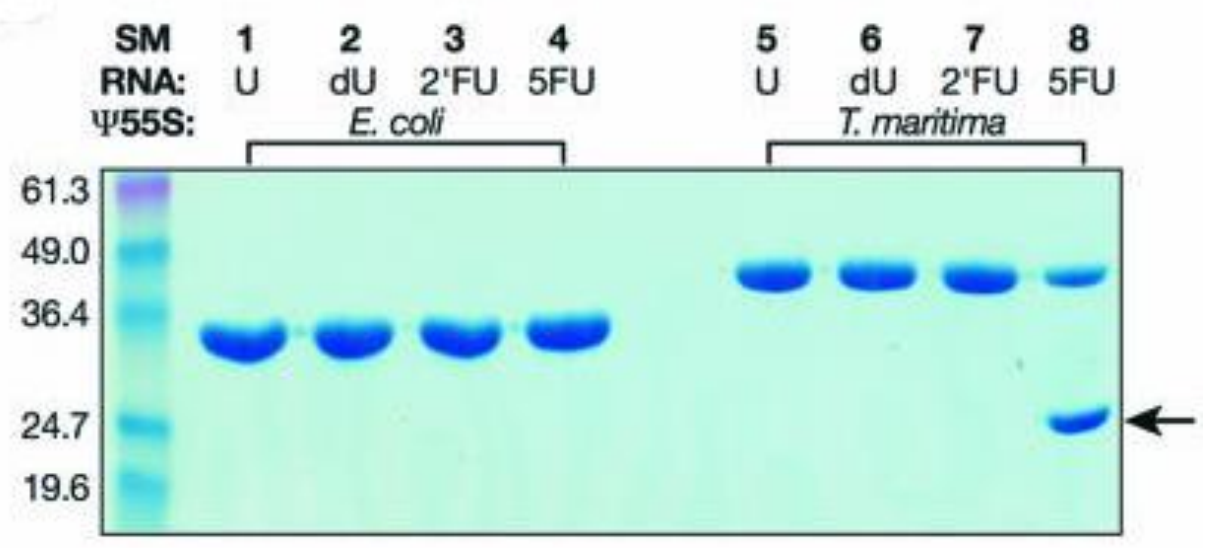

B.

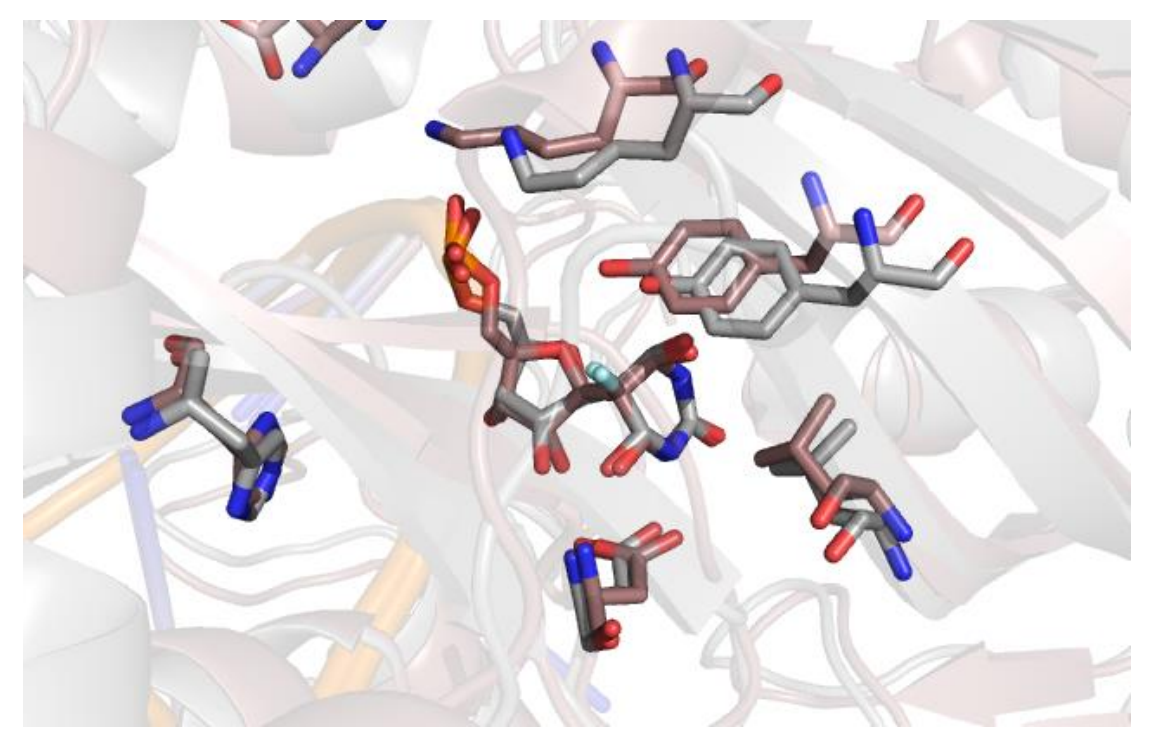

Figure 1.16: A, The interaction of TmTruB and [ $\left.F^{5} U\right] R N A$. [51] An adduct band (indicated by the arrow) was observed when Huang and co-workers incubated TmTruB with [ $\left.\mathrm{F}^{5} \mathrm{U}\right] \mathrm{TSL}$. The increased electrophoretic mobility was attributed to a more compact confirmation that resisted denaturation under the SDS-PAGE conditions. B, A superimposition of the cocrystals of TmTruB and EcTruB with [ $\left.F^{5} U\right]$ RNA show the same product of $F^{5} U$ and nearly identical positioning of the active site residues. 


\section{CHAPTER 2}

\section{MECHANISTIC INVESTIGATIONS OF THERMOTOGA MARITIMA}

TruB

\section{Pseudouridine synthase TruB}

The pseudouridine synthases ( $\Psi$ synthases) isomerize uridine $(U)$ to its C-glycoside isomer pseudouridine $(\Psi)$, which is the most common modified nucleoside in RNA. [1] $\Psi$ synthases are classified into six families that share no statistically significant global sequence similarity. $[18,53]$ The pseudouridine synthase TruB isomerizes the universally conserved U55 in the T-arm of tRNA, [28] and homologs of TruB have been found in all organisms. [54-58] Deletion of the E. coli TruB (EcTruB) gene does not cause a detectable growth defect. However, truB mutants exhibit a competitive disadvantage in extended co-culture with wild-type $E$. coli and a survival defect upon rapid transfer from $37^{\circ} \mathrm{C}$ to $50^{\circ} \mathrm{C}$. [59] Deletion of TruB in Shigella flexneri reduces the expression of some virulenceassociated genes, and disruption of TruB by Tn5 in Pseudomonas aeruginosa causes impaired growth and reduced virulence. [60, 61] TruB-catalyzed $\Psi 55$ modification in Thermus thermophilus is essential for the low temperature 
adaptation of this extremophile. [12] The ubiquity of truB across all eubacteria implies the presence of both TruB and $\Psi 55$ modification in the common ancestor of eubacteria. [62] Though several homologs of TruB have been studied, crystal structures are available only for EcTruB and Thermotoga maritima TruB (TmTruB). $[40,47]$ TmTruB efficiently handles $17-$ mer stem-loop substrates corresponding to the I-arm stem loop (TSL) of tRNA. [29, 47, 63] EcTruB is not inhibited upon incubation with RNA containing 5-fluorouridine ([ $\left.\left.\mathrm{F}^{5} \mathrm{U}\right] \mathrm{RNA}\right)$ whereas TruA and RluA appear to form a covalent adduct with [ $\left.\mathrm{F}^{5} \mathrm{U}\right] \mathrm{RNA}$ and thus become irreversibly inhibited. [30, 36, 42] Three mechanisms have been proposed (Chapter 1), and they all involve an active site aspartic acid residue (hereafter, the 'conserved Asp') that is essential for $\Psi$ synthase activity in all tested cases, which span all six families. [36, 43, 64, 65] The first of these proposed mechanisms-the "Michael mechanism"-involves the conserved Asp nucleophilically attacking the pyrimidine ring at $\mathrm{C} 6$ to form a Michael adduct (Figure 1.4). [36]

When TruA is incubated with [ $\left.\mathrm{F}^{5} \mathrm{U}\right] \mathrm{RNA}$, a slower moving adduct band appears on SDS-PAGE gels; this adduct band collapses to separate protein and RNA bands when the sample is heated prior to loading. [36] Furthermore, mass spectrometric analysis revealed that $\mathrm{F}^{5} \mathrm{U}$ in the RNA is hydrated after the adduct is heat-disrupted. These observations led Santi and co-workers to conclude that the conserved Asp of TruA formed a Michael adduct with [ $\left.\mathrm{F}^{5} \mathrm{U}\right] \mathrm{RNA}$, and heat treatment of this adduct led to hydrolysis of the adduct ester bond to leave the $\mathrm{F}^{5} \mathrm{U}$ hydrated (Figure 2.1). When Hoang and Ferré-D'Amaré later obtained a cocrystal structure of TruB with $\left[\mathrm{F}^{5} \mathrm{U}\right] \mathrm{TSL}$, they observed not a covalent adduct but a 
rearranged hydrated product of $\mathrm{F}^{5} \mathrm{U}$. This unexpected observation led them to conclude that TruB followed the Michael mechanism through the rearrangement step, at which point reaction stopped. The failure to observe the covalent adduct was ascribed to slow ester hydrolysis over the course of crystal growth and diffraction analysis. [40]

Phannachet and Huang attempted to trap a covalent adduct between TruB and $\left[\mathrm{F}^{5} \mathrm{U}\right] \mathrm{TSL}$. They incubated TruB from four different organisms (E. coli, Bacillus subtilis, T. maritima, and Saccharomyces cerevisiae) with [ $\left.\mathrm{F}^{5} \mathrm{U}\right] \mathrm{TSL}$, and denaturing PAGE gel analysis revealed that only TmTruB formed an apparently covalent adduct (Figure 1.7). [47] With TmTruB alone, a new band was observed with greater electrophoretic mobility than the protein alone, and the extracted band showed a maximum absorbance at $260 \mathrm{~nm}$, indicating the presence of RNA (nucleic acids show a characteristic absorption maxima at $260 \mathrm{~nm}$ ). [47] The TmTruB-RNA adduct was also heat labile. Huang and co-workers grew cocrystals of TmTruB with [F5 $\mathrm{F}] \mathrm{TSL}$ and expected to observe a covalent adduct. Despite short crystallization times and low incubation temperatures (48 $\mathrm{h}$ at $4{ }^{\circ} \mathrm{C}$ ), the cocrystal structure of TmTruB with $\left[F^{5} U\right] R N A$ was identical to that of EcTruB, with no evidence of a covalent linkage between the protein and [ $\left.F^{5} U\right] R N A$ and the same rearranged, hydrated product seen in the co-crystal of EcTruB and $\left[F^{5} U\right] R N A$ (Figure 2.2). [47]. Moreover, the RNA-protein complex recovered from the crystals showed similar gel behavior to that of the purified complex prior to crystallization. [47] Because of their failure to trap a covalent adduct, the Huang group did not speculate as to which mechanistic pathway the $\Psi$ synthases follow. 
Spedaliere and Mueller concurrently found that EcTruB is not inhibited by [F5 $\mathrm{E}] \mathrm{TSL}$, instead converting $\mathrm{F}^{5} \mathrm{U}$ into a pair of hydrated $\mathrm{C}$-glycoside isomers $\left(\mathrm{F}^{5} \mathrm{U}^{*}\right)$ in a time frame similar to the conversion of $U$ to $\Psi$. [25] Subsequent NMR experiments reported by Mueller and co-workers confirmed that both $\mathrm{F}^{5} \mathrm{U}$ products were rearranged similarly to the one seen in the cocrystal structure of TruB with [F5 U]RNA. [41] Spedaliere and Mueller also conducted ${ }^{18} \mathrm{O}$ labeling studies with EcTruB to probe the putative ester hydrolysis of the Michael adduct. [42] If the mechanism indeed proceeded through a Michael adduct followed by rearrangement and a relatively fast ester hydrolysis step, running the reaction in $\left[{ }^{18} \mathrm{O}\right]$ water would result in the incorporation of ${ }^{18} \mathrm{O}$ into the conserved Asp (Figure 2.3). Mass spectroscopic analysis of the tryptic digestion products of TruB after incubation with $\left[\mathrm{F}^{5} \mathrm{U}\right] \mathrm{TSL}$ revealed no ${ }^{18} \mathrm{O}$ incorporation into the conserved Asp but instead showed label directly incorporated into $\mathrm{F}^{5} \mathrm{U}^{*}$. [42] These studies were later extended to the E. coli $\Psi$ synthases RluA, TruA, and TruD, all of which showed the incorporation of ${ }^{18} \mathrm{O}$ directly into RNA rather than the conserved Asp. [30, 42, 66, 67] These results led to the proposal of a scheme for the hydration step consistent with all observations (Figure 2.4). [42] The $\mathrm{F}^{5} \mathrm{U}$ is rearranged by either mechanism, and then idiosyncrasies in the active site geometry dictate the fate of the initial product. In the case of TruA and RluA, the conserved Asp can form a stable covalent adduct with $\mathrm{C} 6$ of the pyrimidine ring, and upon heating, it undergoes elimination followed by spontaneous hydration of the rearranged $\mathrm{F}^{5} \mathrm{U}$ in solution. With TruB, the conserved Asp cannot form a stable adduct, so the rearranged $F^{5} \mathrm{U}$ is simply released into solution where it undergoes spontaneous hydration. [66] 

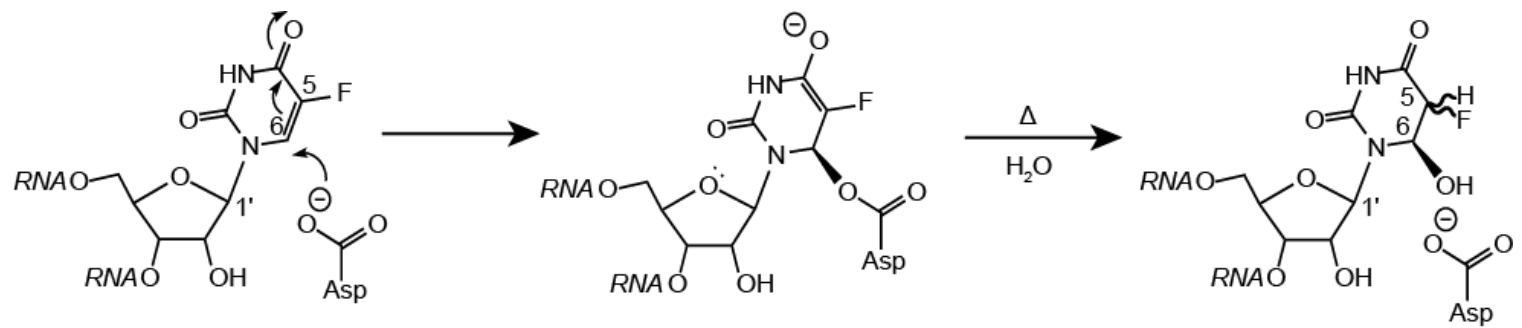

cis-(5S, 6R)-6-hydroxy,

5, 6-dihydro-5-fluorouridine

Figure 2.1: The Michael adduct proposed by Santi and co-workers between the conserved Asp and C6 of the pyrimidine ring. Heat disruption of the adduct results in a hydrated product of $F^{5} U$. [36] 

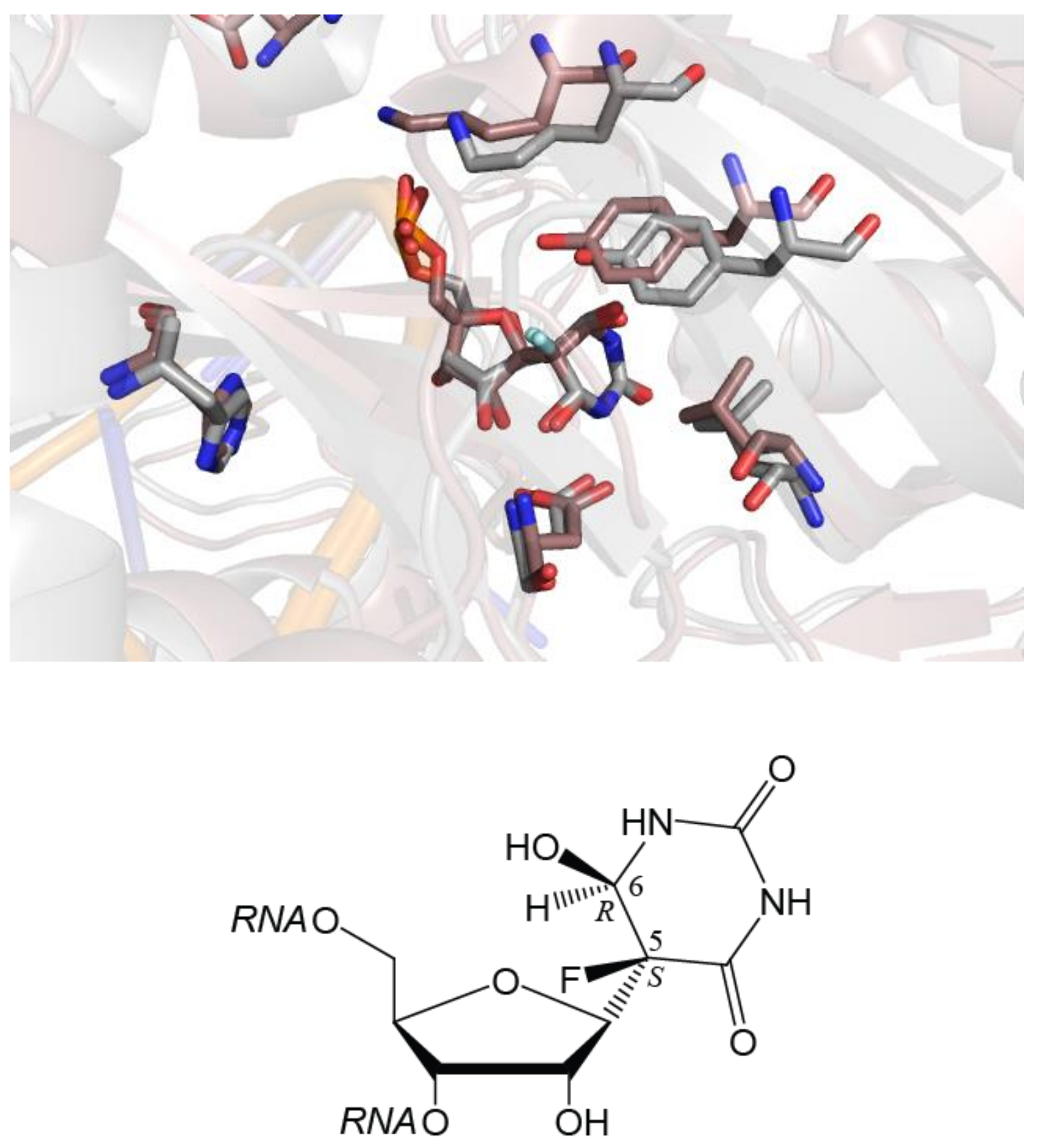

Figure 2.2: An overlay of the cocrystal structures of EcTruB and TmTruB with [ $\left.F^{5} \mathrm{U}\right] \mathrm{RNA}$ and the line drawing of the rearranged, hydrated product of $F^{5} U$ seen in the cocrystal structures of TruB with [F5]RNA. $[40,47]$ 
$A$
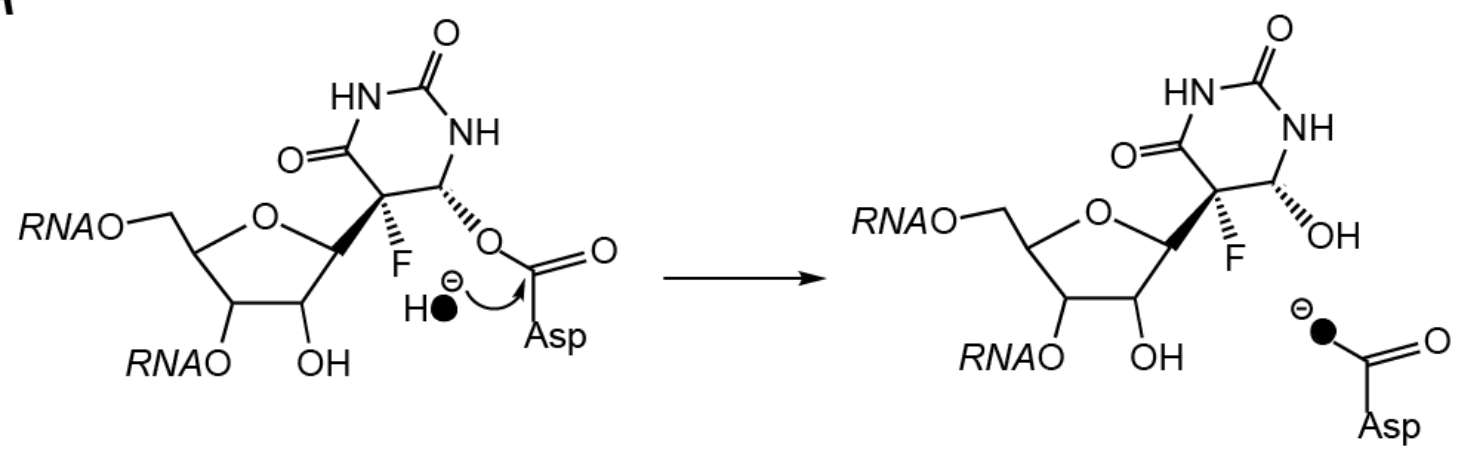

$B$
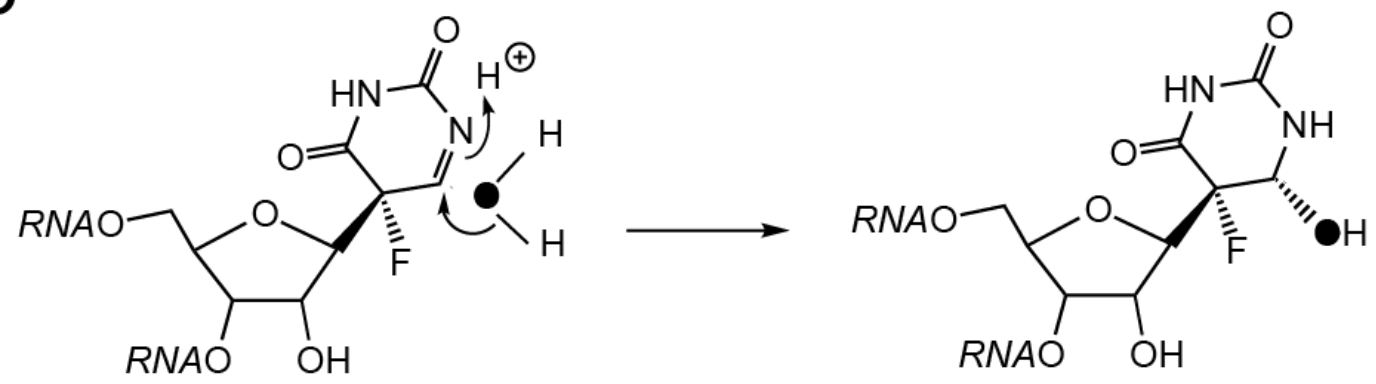

Figure 2.3: Scheme for the ${ }^{18} \mathrm{O}$ labeling studies. A, Ester hydrolysis would result in the incorporation of ${ }^{18} \mathrm{O}$ into the conserved Asp. B, Direct hydration of the rearranged product of $F^{5} U$ results in labeled $F^{5} U^{*}$. 


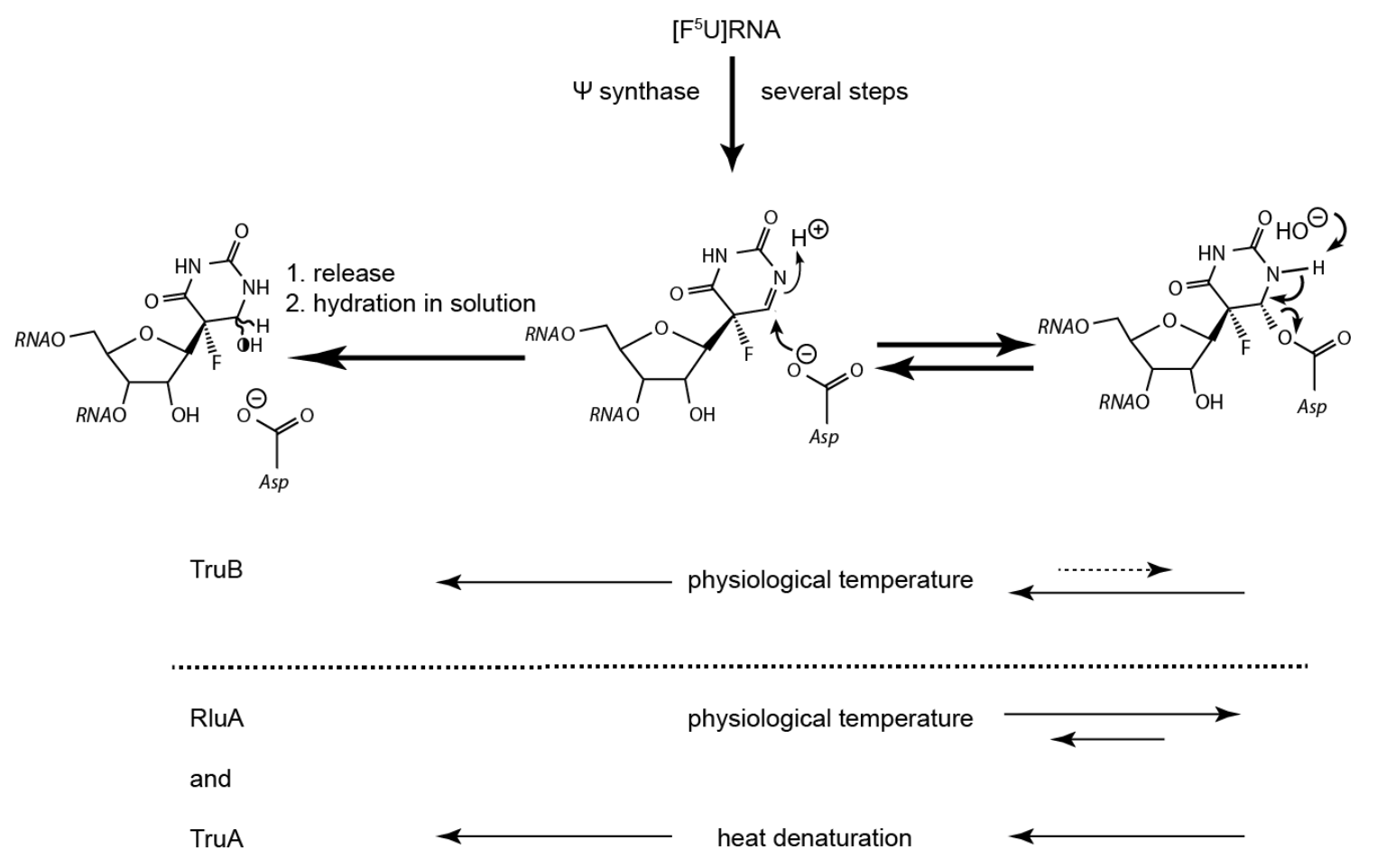

Figure 2.4: Scheme accounting for the formation of apparently covalent adducts by TruA and RluA but not TruB and for the generation of two hydrated products by all three $\Psi$ synthases. [66] 
This chapter describes investigation into the behavior of TmTruB towards $\left[F^{5} \mathrm{U}\right] \mathrm{RNA}$. They were undertaken to resolve apparent discrepancies from gel analysis (a covalent adduct appears to form) and X-ray crystallography (no adduct is observed). The results were expected to illuminate the mechanism and also resolve some questions raised by the partial characterization of TmTruB reported by Phannachet and Huang. [47] First, do TmTruB and EcTruB show similar kinetics, and if not, how do they differ? Second, although TmTruB forms an adduct with [ $\left.\mathrm{F}^{5} \mathrm{U}\right] \mathrm{TSL}$ as judged by SDS-PAGE analysis, the nature of this adduct as covalent or very tight but noncovalent remained uncertain. Third, if the adduct is covalent, is it the proposed Michael adduct between the C6 of the pyrimidine ring and the conserved Asp, or an adduct with some other active site amino acid residue? 


\section{Experimental}

\section{Materials}

All chemicals, unless specified were purchased from Fisher Scientific (Pittsburgh, PA) or Sigma-Aldrich (Milwaukee, WI). BLR(DE3) pLysS cells were purchased from Novagen (Madison, WI). A DNAPac ${ }^{\circledR}$ PA200 column $(4 \times 250 \mathrm{~mm})$ was purchased from Dionex (Sunnyvale, CA). A CLIPEUS $\mathrm{C}_{8} 5-\mu \mathrm{m}$ column $(250 \times$ $4.6 \mathrm{~mm}$ ) was purchased from Higgins Analytical, Inc. (Mountain View, CA), and a Zorbax analytical SB-C18 5- $\mu \mathrm{m}$ column $(50 \times 4.6 \mathrm{~mm})$ was purchased from Agilent (Santa Clara, CA). A HiPrep 16/60 Sephacryl S-200 HR size exclusion column and Sephadex G-25 resin were purchased from GE Healthcare (Pittsburgh, PA). NiNTA superflow resin and QIAprep Spin Mini prep kits were purchased from Qiagen (Chatsworth, CA). S1 nuclease and calf intestinal alkaline phosphatase were purchased from Promega (Madison, WI). Modified trypsin (sequencing grade), endoproteinase Glu-C (sequencing grade), and RNase T1 were purchased from Roche (Indianapolis, IN). QuickChange ${ }^{\mathrm{TM}}$ site-directed mutagenesis kits were purchased from Stratagene (La Jolla, CA). $\left[{ }^{18} \mathrm{O}\right]$ water $(99.7 \%$, v/v) was purchased from Sigma-Aldrich (Milwaukee, WI). Ultra-pure deionized water was obtained using a Millipore ${ }^{\circledR}$ Milli-Q integral system (Billerica, MA) equipped with a $0.2 \mu \mathrm{m}$ filter. Laemmli buffer $(2 \mathrm{x})$ was $120 \mathrm{mM}$ Tris• $\mathrm{HCl}$ buffer, $\mathrm{pH}$ 6.8, containing SDS $(4 \%, w / v)$, glycerol $(20 \%, v / v)$, and bromophenol blue $(0.02 \%, w / v)$. RNA loading

dye (2x) was $95 \%$ aqueous formamide, containing bromophenol blue $(0.025 \%$, w/v), xylene cyanol $(0.025 \%, w / v)$, and EDTA $(0.5 \mathrm{mM})$. 


\section{Subcloning, overexpression, and purification of wild-type and D39A TmTruB}

The recombinant plasmid for TmTruB (pUL390) was prepared by ligating T. maritima truB into the expression vector $\mathrm{pET}-15 \mathrm{~b}$ (Novagen) so that an $\mathrm{N}$-terminal His6॰tag was fused to expressed TmTruB. The plasmid encoding D39A TmTruB (pUL391) was created by introducing a point mutation into truB in pUL390 using the Stratagene QuickChange ${ }^{\mathrm{TM}}$ site-directed mutagenesis kit according to the manufacturer's protocols and with the following primers: GGACACGGAGGAACTCTCGCCCCGTTCGCCTGTGGG (forward), and CCCACAGGCGAACGGGGCGAGAGTTCCTCCGTGTCC (reverse). The inserts in both plasmids (pUL390, pUL391) were verified by DNA sequencing. BLR(DE3) pLysS cells were transformed with pUL390 and pUL391 for the overexpression of wild-type and D39A TmTruB, respectively. Both were purified over Ni-NTA resin using the same protocol used for EcTruB. [64] TmTruB was further purified over a POROS HQ anion exchange column (PE Biosystems) attached to a BioCAD SPRINT FPLC run by Perfusion Chromatography Workstation v3.01. Elution was achieved by the application of a gradient of sodium chloride $(0-1.0 \mathrm{M})$ in $25 \mathrm{mM}$ Tris $\bullet \mathrm{HCl}$ buffer, $\mathrm{pH}$ 7.5. TmTruB generally eluted at 250-400 mM salt. Fractions bearing TmTruB were tested for RNase contamination, and the RNase-free fractions were heat treated for 15 min at $70{ }^{\circ} \mathrm{C}$ followed by centrifugation $(18,000 \mathrm{~g}, 15 \mathrm{~min})$ to pellet precipitated proteins. The combined pure fractions of TmTruB were adjusted to $70 \%$ nominal saturation with solid ammonium sulfate and stored at $4{ }^{\circ} \mathrm{C}$. Immediately prior to use, aliquots of the ammonium sulfate suspension of TmTruB were diluted with an equal volume 
of $25 \mathrm{mM}$ Tris $\bullet \mathrm{HCl}$ buffer, $\mathrm{pH} 7.5$, containing sodium chloride $(250 \mathrm{mM})$ and desalted by passage over a column of G-25 resin, equilibrated in the same buffer.

\section{RNA substrates}

RNA oligonucleotides were obtained from GE Dharmacon (Lafayette, CO) and deprotected according to the manufacturer's protocol. Following deprotection, RNA was desalted by ultrafiltration using a Centricon-3 device to achieve dilution of small molecules initially present (>1000-fold) and was further purified by reverse phase HPLC over a preparatory C18 column using a gradient of acetonitrile in 25 $\mathrm{mM}$ ammonium acetate buffer, $\mathrm{pH}$ 6.0. RNA-bearing fractions were taken to dryness in vacuo in a Savant DNA120 speedvac (Thermo Electron), redissolved in RNase-free water, and stored as aliquots at $-80^{\circ} \mathrm{C}$ until further use.

\section{Digestion and MALDI-MS analysis of TmTruB and TmTSL}

TmTruB. Solutions of wild-type or D39A TmTruB $(50 \mu \mathrm{g})$ were incubated for $15 \mathrm{~min}$ at $94{ }^{\circ} \mathrm{C}$ to denature the protein. The precipitate was then pelleted by centrifugation $(18,000 \mathrm{~g}, 15 \mathrm{~min})$, and the protein pellet was suspended in $25 \mathrm{mM}$ sodium phosphate buffer $(100 \mu \mathrm{L}), \mathrm{pH} 7.8$, containing trypsin $(0.01 \mathrm{mg} / \mathrm{ml})$, endoproteinase Glu-C (0.02 mg/ml), and acetonitrile (10\% v/v). This mixture was incubated for $12 \mathrm{~h}$ at $25^{\circ} \mathrm{C}$. An aliquot $(10 \mu \mathrm{L})$ was drawn up into ZipTip $\mathrm{C} 18_{\text {pipetter }}$ tip (Millipore, Bedford, MA) and then expelled; the bound peptides were washed $(10 \times 10 \mu \mathrm{L})$ with aqueous trifluoroacetic acid $(0.1 \% \mathrm{v} / \mathrm{v})$ and eluted with $\mathrm{Cl}-\mathrm{CCA}$ matrix solution (5 $\mu \mathrm{L})$, which was 4-chloro-a-cyanocinnamic acid $(6.24 \mathrm{mg} / \mathrm{ml})$ in $70 \%$ aqueous acetonitrile containing trifluoroacetic acid $(0.1 \% \mathrm{v} / \mathrm{v})$. The ZipTip 
eluate $(1 \mu \mathrm{L})$ was spotted on a MALDI sample plate, air dried, and analyzed on a Voyager DE-Pro MALDI-TOF instrument (PE Biosystems, Foster City, CA). Spectra were acquired in positive reflectron mode with an extraction delay time of $200 \mathrm{~ns}$ and 400 laser shots per spectrum. Calibration was achieved using a 1:1:2 mixture of Bradykinin fragment 1-7 $(757.399 \mathrm{~m} / \mathrm{z})$, fragment 18-39 of ACTH $(2465.1989 \mathrm{~m} / \mathrm{z})$, and the oxidized $\beta$-chain of insulin $(3494.6513 \mathrm{~m} / \mathrm{z})$ purchased from Sigma-Aldrich (St. Louis, MO).

$R N A$. An aliquot of RNA (10 $\mu \mathrm{L}, 100 \mu \mathrm{M})$ was diluted into RNase-free water $(40 \mu \mathrm{L})$ to which RNase T1 (2 $\mu \mathrm{L}, 200 \mathrm{U})$ or RNase A ( $2 \mu \mathrm{L}, 200 \mathrm{U})$ was added and incubated for $1 \mathrm{~h}$ at $37^{\circ} \mathrm{C}$. Following this, alkaline phosphatase $(5 \mu \mathrm{L}, 5 \mathrm{U})$ was added to the digestion mixture, which was additionally incubated for $3 \mathrm{~h}$ at 37 ${ }^{\circ} \mathrm{C}$. An aliquot $(3 \mu \mathrm{L})$ of the digest was mixed with the 3-HPA matrix solution $(3 \mu \mathrm{L})$, which was 3-hydroxypicolinic acid (3-HPA; Fluka, Milwaukee, Wl; $10 \mathrm{mg} / \mathrm{ml}$ ) in $50 \%$ aqueous acetonitrile. The sample was spotted on a MALDI plate, air dried, and analyzed. Mass spectra were acquired either in positive or negative reflectron mode; calibration was achieved by a conventional 3-point method using a mixture of standard oligonucleotides: TTTGCTT (2076.37 monoisotopic mass), $\mathrm{T}_{10}$ (2978.49), and $T_{15}$ (4498.721) purchased from GE Dharmacon. Data was analyzed with mMASS data analysis software, version 5.5.1. [68]

\section{Kinetic analysis of TmTruB}

Standard reaction buffer was $25 \mathrm{mM}$ Tris $\bullet \mathrm{HCl}$ buffer, $\mathrm{pH} 7.5$, containing sodium chloride $(250 \mathrm{mM})$ and DTT $(5 \mathrm{mM})$. The reaction mixtures $(1200-4000 \mu \mathrm{L})$ were standard reaction buffer containing TmTSL (50-2500 nM). After pre- 
incubation for $3 \mathrm{~min}$ at $58^{\circ} \mathrm{C}$, reactions were initiated by the addition of a small volume $(<6 \mu \mathrm{L}$ ) of TmTruB (to $1.5 \mathrm{nM})$. Aliquots $(300-1000 \mu \mathrm{L})$ were removed at various time intervals $(30,60,90$, and $120 \mathrm{~s})$ and quenched by extracting TmTruB into an equal volume of chilled $\left(4^{\circ} \mathrm{C}\right)$ phenol saturated with $10 \mathrm{mM}$ Tris•EDTA buffer, $\mathrm{pH}$ 4.5. After a second extraction with 1:1 phenol:chloroform saturated with the same buffer, the RNA was precipitated with ethanol, pelleted by centrifugation, and air-dried. The pelleted RNA was redissolved in standard reaction buffer (100 $\mu \mathrm{L})$, passed through a Corning Costar ${ }^{\mathrm{TM}}$ spin filter $(0.22 \mu \mathrm{m})$, and analyzed by HPLC over a DNAPac ${ }^{\circledR}$ PA200 column connected to an Agilent 1100 HPLC system equipped with an IC-3000 binary pump (Dionex, Sunnyvale, CA). RNA samples were eluted using a gradient of sodium chloride $(100-1.25 \mathrm{M})$ in $100 \mathrm{mM}$ Tris $\bullet \mathrm{HCl}$ buffer, $\mathrm{pH}$ 9.0, by use of the following program (the first number is the percentage of high salt buffer, which is $100 \mathrm{mM}$ Tris $\bullet \mathrm{HCl}$ buffer, $\mathrm{pH}$ 9.0, containing sodium chloride (1.25 M); the second number is the elapsed time in minutes): $0,26.4 ; 1$, $26.4 ; 26,57.6 ; 26,80 ; 27,80 ; 27,26.4 ; 40,26.4$.

\section{Analysis of the TmTruB-[F5]TmTSL adduct}

TmTruB and $\left[\mathrm{F}^{5} \mathrm{U}\right] \mathrm{TmTSL}$ were incubated in standard reaction buffer at $58^{\circ} \mathrm{C}$. After $3 \mathrm{~h}$, the sample was either heated to $94^{\circ} \mathrm{C}$ and held for $5-15 \mathrm{~min}$ or loaded directly onto the gel. The SDS-PAGE gels (10\%) were stained with Coomassie ${ }^{\mathrm{TM}}$ blue, and the urea-PAGE gels $(12 \%, 7 \mathrm{M}$ urea) were first stained with SYBR $^{\circledR}$ Gold stain (to visualize RNA) followed by Coomassie ${ }^{\text {TM }}$ blue (to visualize protein). Occasionally, RNA used in adduct studies was visualized by virtue of the 
fluorescence of an attached fluorescein (FI) moiety by purchasing RNA with a 5'Fl label.

The time course for the formation of $\left[\mathrm{F}^{5} \mathrm{U}^{\star}\right] \mathrm{TmTSL}$ was obtained by incubating TmTruB $(5 \mu \mathrm{M})$ with $\left[\mathrm{F}^{5} \mathrm{U}\right] \mathrm{TmTSL}(10 \mu \mathrm{M})$ in standard reaction buffer at $58{ }^{\circ} \mathrm{C}$. Aliquots of the reaction mixture $(20 \mu \mathrm{L})$ were withdrawn at regular time intervals and immediately quenched by mixing with $2 x$ Laemmli buffer or $2 x$ RNA loading dye $(20 \mu \mathrm{L})$ and incubating at $94^{\circ} \mathrm{C}$ for $5 \mathrm{~min}$. After cooling the tubes on ice for 5 min, samples were analyzed by SDS-PAGE and urea-PAGE. Aliquots of the reaction mixture $(15 \mu \mathrm{L})$ were also withdrawn at regular time intervals to test for the formation of $\left[\mathrm{F}^{5} \mathrm{U}^{*}\right] \mathrm{TmTSL}$ by HPLC analysis. The withdrawn aliquots were immediately quenched by the extraction of protein into 1:1 phenol:chloroform as described above. The RNA was precipitated from the separated aqueous phase with ethanol, pelleted by centrifugation, air-dried, redissolved in water $(100 \mu \mathrm{L})$, and filtered $(0.22 \mu \mathrm{m})$ for HPLC analysis.

\section{Size exclusion studies}

TmTruB and size standards were diluted into either $25 \mathrm{mM}$ Tris $\bullet \mathrm{HCl}$ buffer, $\mathrm{pH} 7.5$, containing sodium chloride $(250 \mathrm{mM})$ or $50 \mathrm{mM}$ sodium phosphate buffer, $\mathrm{pH} 7.0$, containing sodium chloride $(150 \mathrm{mM})$ to a final concentration of $2-5 \mathrm{mg} / \mathrm{ml}$ and loaded on to a HiPrep Sephacryl S-200 HR $(16 \times 600 \mathrm{~mm})$ size exclusion column fit to a BioCAD SPRINT FPLC run by Perfusion Chromatography Workstation v3.01; elution was accomplished with the same buffer flowing at 0.4 $\mathrm{mL} / \mathrm{min}$. For studies with the adduct, TmTruB $(50 \mu \mathrm{M})$ and $\left[\mathrm{F}^{5} \mathrm{U}\right] \mathrm{TmTSL}(50 \mu \mathrm{M})$ were initially incubated in standard reaction buffer for $3 \mathrm{~h}$ at $58^{\circ} \mathrm{C}$. Following 
analysis by urea-PAGE to assess adduction, the sample (without dilution) was injected onto the Sephacryl S-200 column and eluted isocratically with standard reaction buffer.

\section{${ }^{18} \mathrm{O}$ labeling studies}

To allow pre-equilibration of water molecules in the active site with bulk solvent, TmTruB $(20 \mu \mathrm{M})$ was incubated either in standard reaction buffer $(250 \mu \mathrm{L})$ or in the same buffer $(250 \mu \mathrm{L})$ containing $50 \%\left[{ }^{18} \mathrm{O}\right] \mathrm{H}_{2} \mathrm{O}$ for $5 \mathrm{~min}$ at $58{ }^{\circ} \mathrm{C}$. The reaction was initiated by adding a small aliquot $(5.6 \mu \mathrm{L})$ of [ $\left.\mathrm{F}^{5} \mathrm{U}\right] \mathrm{TmTSL}(40 \mu \mathrm{M})$. After $3 \mathrm{~h}$, an aliquot $(60 \mu \mathrm{L})$ of the reaction mixture was analyzed by urea-PAGE and SDS-PAGE to assess adduct formation, and another aliquot $(5 \mu \mathrm{L})$ of the reaction mixture was diluted into $\mathrm{S} 1$ nuclease digestion buffer $(95 \mu \mathrm{L})$, which is 30 $\mathrm{mM}$ sodium acetate buffer, $\mathrm{pH} 4.6$, containing sodium chloride $(50 \mathrm{mM})$, zinc chloride (10 mM), and glycerol (5\%, v/v). S1 nuclease $(0.5 \mu \mathrm{L}, 50 \mathrm{U})$ was added, and the mixture was incubated for $1 \mathrm{~h}$ at $37^{\circ} \mathrm{C}$; the digest was then incubated for 5 min at $94^{\circ} \mathrm{C}$ followed by incubation on ice for $5 \mathrm{~min}$. Subsequently, a fresh aliquot of $\mathrm{S} 1$ nuclease $(1 \mu \mathrm{L}, 100 \mathrm{U})$ and alkaline phosphatase ( $3 \mu \mathrm{L}, 3 \mathrm{U})$ were added, and the mixture was incubated for $3 \mathrm{~h}$ at $37^{\circ} \mathrm{C}$. The digest was then analyzed over an SB-C18 analytical column connected to Beckman Coulter System Gold HPLC (Indianapolis, IN) equipped with a model diode array detector.

For the unlabeled reaction, the remainder of the reaction mixture $(185 \mu \mathrm{L})$ was incubated for $15 \mathrm{~min}$ at $94{ }^{\circ} \mathrm{C}$ then placed on ice for $5 \mathrm{~min}$. Precipitated 
TmTruB was pelleted by centrifugation $(18,000 \mathrm{~g}, 15 \mathrm{~min})$. The supernatant was removed, and residual protein was extracted with 1:1 phenol:chloroform as described above. The RNA was precipitated with ethanol, and the resultant pellet was washed with cold ethanol $(70 \%, v / v)$, air-dried, and dissolved in RNase-free water $(100 \mu \mathrm{L})$. To this solution, $\mathrm{RNase}_{1}(3 \mu \mathrm{L}, 300 \mathrm{U})$ was added, and the mixture was incubated for $1 \mathrm{~h}$ at $37^{\circ} \mathrm{C}$. Following this, alkaline phosphatase $(5 \mu \mathrm{L}, 5 \mathrm{U})$ was added to the digestion mixture, which was incubated for $3 \mathrm{~h}$ at $37^{\circ} \mathrm{C}$. An aliquot $(3 \mu \mathrm{L})$ of the resulting dephosphorylated oligonucleotides was mixed with 3-HPA matrix solution $(3 \mu \mathrm{L})$, spotted onto MALDI plate, and air dried for acquisition of mass spectra. Another aliquot $(0.5 \mu \mathrm{L})$ of the digest was mixed with the 3-HPA matrix solution $(0.5 \mu \mathrm{L})$ made with $50 \%\left[{ }^{18} \mathrm{O}\right]$ water, and mass spectra were acquired. Finally, an aliquot $(3 \mu \mathrm{L})$ of the digest was diluted 1:1 with $\left[{ }^{18} \mathrm{O}\right]$ water and incubated for $3 \mathrm{~h}$ at $37^{\circ} \mathrm{C}$ before mixing with 3-HPA matrix solution $(3 \mu \mathrm{L})$ and analysis by mass spectrometry.

A part of the pellet (TmTruB) from the unlabeled reaction was suspended in $25 \mathrm{mM}$ sodium phosphate buffer $(50 \mu \mathrm{L}), \mathrm{pH}$ 7.8. To this, trypsin $(1 \mu \mathrm{g})$ and endoproteinase Glu-C $(2 \mu \mathrm{g})$ were added, and the mixture was incubated for $12 \mathrm{~h}$ at $25^{\circ} \mathrm{C}$. An aliquot $(10 \mu \mathrm{L})$ of the digestion mixture was desalted using a ZipTip ${ }_{\mathrm{C} 18}$ as described above, and the bound peptides were eluted in $70 \%$ aqueous acetonitrile containing trifluoroacetic acid $(0.1 \% \mathrm{v} / \mathrm{v})$. The ZipTip eluate $(1 \mu \mathrm{L})$ was mixed with $\mathrm{Cl}-\mathrm{CCA}$ matrix solution $(1 \mu \mathrm{L})$ spotted on a MALDI sample plate, air dried, and analyzed. An aliquot of the ZipTip-purified sample $(3 \mu \mathrm{L})$ was mixed with $\mathrm{Cl}-\mathrm{CCA}$ matrix solution prepared in $50 \%\left[{ }^{18} \mathrm{O}\right]$ water and analyzed. The rest of the 
pellet from the unlabeled reaction was suspended in sodium phosphate buffer, $\mathrm{pH}$ 7.8 , containing $\left[{ }^{18} \mathrm{O}\right]$ water $(50 \%, \mathrm{v} / \mathrm{v})$ and digested with trypsin/endonuclease GluC $(1 \mu \mathrm{g} / 2 \mu \mathrm{g})$ as described above. The resulting peptide mixture was desalted and concentrated using a ZipTip ${ }_{\mathrm{C} 18}$, and an aliquot of the eluate $(1 \mu \mathrm{L})$ was mixed with Cl-CCA matrix solution $(1 \mu \mathrm{L})$ and analyzed.

For the labeled reaction, the ${ }^{18} \mathrm{O}$ content of the buffer was either maintained at $50 \%$ or diluted to $10 \%$ prior to heat disruption of the adduct. Following heat disruption, the protein and RNA were separated, digested, and analyzed as described for the unlabeled reaction. For pre-incubation studies with it, $\left[\mathrm{F}^{5} \mathrm{U}^{\star}\right] \mathrm{TmTSL}$ was prepared by incubating $\operatorname{TmTruB}(45 \mu \mathrm{M})$ with $\left[\mathrm{F}^{5} \mathrm{U}\right] \mathrm{TmTSL}(70$ $\mu \mathrm{M})$ in standard reaction buffer $(150 \mu \mathrm{L})$ for $3 \mathrm{~h}$ at $58^{\circ} \mathrm{C}$. Following this, RNA was isolated as described above and purified over the DNAPac PA200 column. Purified $\left[\mathrm{F}^{5} \mathrm{U}^{*}\right] \mathrm{TmTSL}(10 \mu \mathrm{M})$ was then pre-incubated in standard reaction buffer containing $\left[{ }^{18} \mathrm{O}\right]$ water $(50 \%, \mathrm{v} / \mathrm{v})$, and $\operatorname{TmTruB}(10 \mu \mathrm{M})$ was added immediately prior to heat-treating the mixture for $15 \mathrm{~min}$ at $94{ }^{\circ} \mathrm{C}$. Following this, RNA and protein were separated, digested, and analyzed as described above. 


\section{Results}

\section{Subcloning, overexpression, and purification of TmTruB}

The expression vectors pUL390 and pUL391 were created to encode wildtype and D39A TmTruB, respectively, with an N-terminal His $6^{\bullet}$ tag. Both proteins were overexpressed by standard methods, [64] and TmTruB was purified to near homogeneity by nickel affinity chromatography followed by anion exchange chromatography and heat treatment (Figure 2.5). The final step was possible because TmTruB is thermostable whereas the impurities (E. coli cellular proteins) are denatured by heat and then easily removed by centrifugation. Initially, the concentrations of TmTruB were determined by biuret assay [69] and the method of Gill and von Hippell [70], which uses $A_{280}$ of denatured protein and a calculated sequence-dependent extinction coefficient. These values were in reasonable agreement and used to determine $\varepsilon_{280}$ for the native protein and a conversion factor for the Bio-Rad protein assay with bovine serum albumin as the standard. [71] Subsequently, $A_{280}$ or the Bio-Rad assay were used to determine the concentration of TmTruB. For long-term stability, pure fractions of TmTruB were pooled and concentrated to $2-5 \mathrm{mg} / \mathrm{ml}$, and ammonium sulfate was added to nominal $70 \%$ saturation. Of several storage conditions tested, this one was found to be superior as judged by periodic activity assays. [72] Under these conditions, TmTruB retained $>80 \%$ activity over six months. 


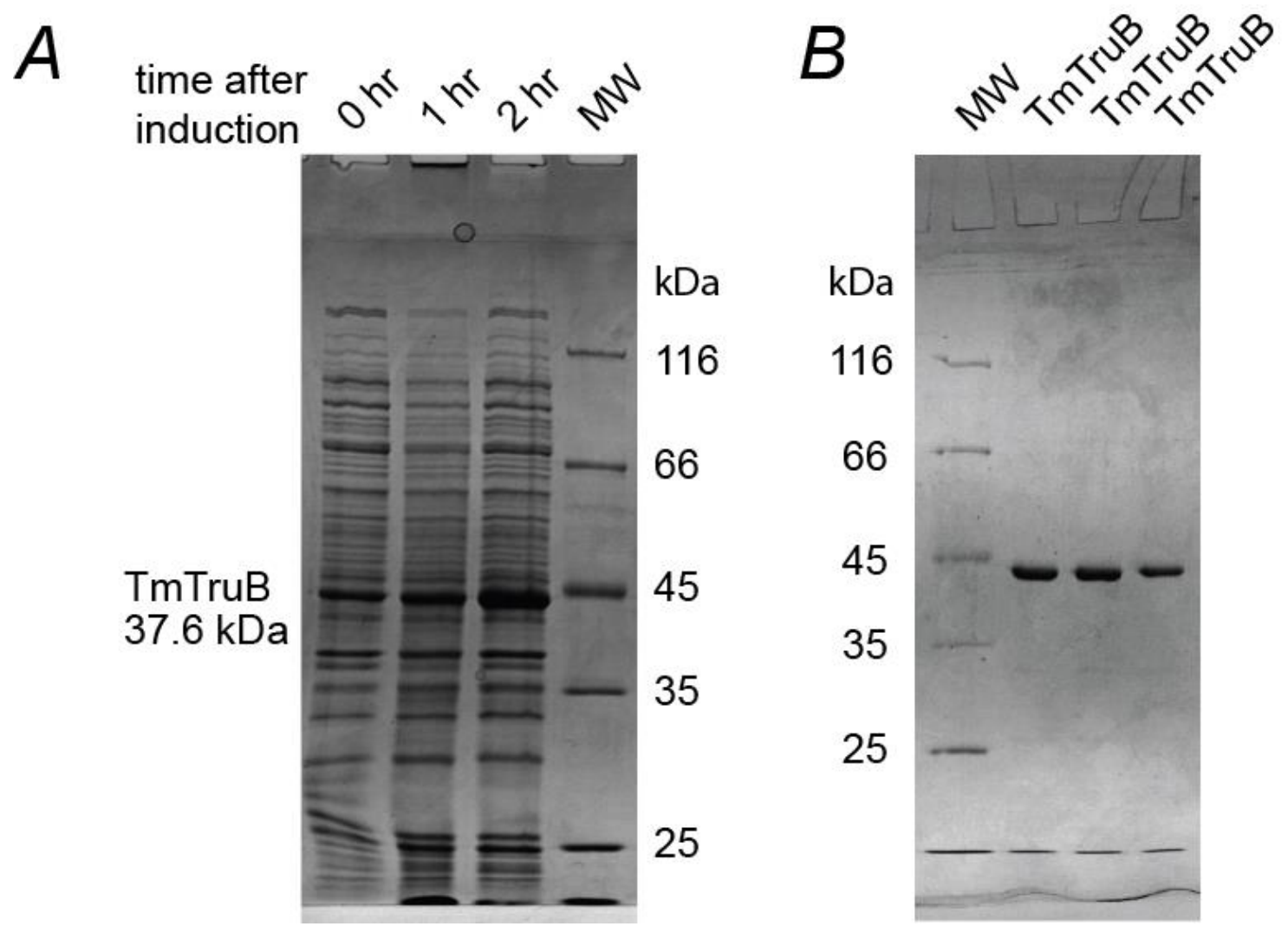

Figure 2.5: SDS-PAGE analysis of the overexpression and purification of TmTruB (37.6 kDa). A, Overexpression of TmTruB. B, Purified fractions of TmTruB. MW, EZ-Run ${ }^{\mathrm{TM}}$ protein markers (Fisher Scientific; Waltham, MA). 


\section{Kinetic characterization of TmTruB}

The kinetic characterization of TmTruB had not been previously reported, so the first goal was to determine $k_{\text {cat }}$ and $K_{m}$ for comparison with those of its mesophilic homolog EcTruB. In order to establish a convenient and informative assay, several conditions had to be optimized, including quench methodology, temperature, substrate, and reaction buffer.

\section{Quench conditions}

Most fundamentally, a discontinuous assay requires an efficacious quenching of the reaction, so several quench conditions were scouted. Heat was

excluded as an efficient quencher because $T$. maritima is an extremophile that grows optimally at $65-90^{\circ} \mathrm{C}$. [73] Quench by the extraction of protein with phenol was found to be effective and convenient. The efficacy of phenol quench was verified by analyzing time points for each assay immediately after addition of TmTruB to initiate the reaction. HPLC analysis of these time points showed $<1 \%$ conversion of substrate $\left(\operatorname{TmTSL}^{\cup}\right)$ to product $\left(\mathrm{TmTSL}^{\Psi}\right)$.

\section{Reaction temperature and choice of substrate}

Generally, an assay temperature should be in close proximity to the growth optimum for the host organism, which is $60-85^{\circ} \mathrm{C}$ for $T$. maritima. Furthermore, since the RNA substrate needs to adopt its folded conformation to be handled by TmTruB, the assay temperature must be at least several degrees below the 
melting temperature $\left(T_{\mathrm{m}}\right)^{2}$ of the substrate to assure a preponderance of folded RNA. Three different TSL substrates from E. coli, T. maritima, and T. thermophilus tRNAs were scouted for this purpose (Figure 2.6). The TSL from T. maritima tRNA $^{\text {Phe }}\left(\right.$ TmTSL $\left.^{U}\right)$ was chosen because it has a suitable melting temperature $\left(T_{\mathrm{m}}=68-72{ }^{\circ} \mathrm{C}\right)$ and represents the exact sequence of one TmTruB substrate (tRNA ${ }^{\text {Phe }}$. [74] The optimal reaction temperature was found by incubating TmTruB (25 nM) with $\operatorname{TmTSL}^{\cup}(1 \mu \mathrm{M})$ at various temperatures $\left(4-85{ }^{\circ} \mathrm{C}\right)$ in standard reaction buffer for $1 \mathrm{~h}$ followed by measurement of the amount of product $\left(\operatorname{TmTSL}^{\Psi}\right)$. To achieve that end, the RNA was digested with S1 nuclease and alkaline phosphatase. The resulting nucleosides were separated by HPLC over a $\mathrm{C}_{18}$ column with quantification by $\mathrm{A}_{260}$ normalized using $\varepsilon_{280}$ of the nucleosides (Figure 2.7, panel A). For the reactions run between 50 and $85^{\circ} \mathrm{C}$, complete conversion was observed after $1 \mathrm{~h}$. A reaction temperature of $58^{\circ} \mathrm{C}$ was chosen because it was convenient and well below the melting temperature of TmTSLU.

\section{RNA digestion}

The measurement of the concentration of $\operatorname{TmTSL}^{\psi}$ with minimal manipulation and maximal sensitivity would be best. The preliminary assays described above relied on digestion of TSL E. coli tRNA ${ }^{\text {Phe }}$ to its component nucleosides and their quantitation. Although effective, this method requires digestion, and the sensitivity is limited by the absorbance of $\Psi$. The greater absorbance of intact TSL (due to the contribution of all 17 component nucleosides)

\footnotetext{
2 The melting temperature $\left(T_{\mathrm{m}}\right)$ is the temperature at which half of the RNA population is in the folded conformation (hairpin loop) and half is denatured.
} 
enhances sensitivity, and the absence of a digestion step is clearly more convenient. Intact E. coli TSL ${ }^{U}$, however, cannot be separated from E. coli $\mathrm{TSL}^{\Psi}$ despite myriad attempts with a wide array of elution conditions from numerous column matrices. Digestion with RNase A or RNase T1 places the product nucleoside in a smaller oligonucleotide, which maintains some advantage in sensitivity (although still requiring an 'extra' manipulation) and should allow more facile separation of substrate and product since the difference between them is now in a context less likely to overwhelm it. However, the oligonucleotide with $\Psi$ after digestion of $E$. coli TSL with either RNase was not readily separated from its parent with U.

Fortunately, intact TmTSL proved more amenable to the needs of the assay. In addition to the reasons stated above for choosing it as the standard substrate, it was also recommended by the ready separation of $\mathrm{TmTSL}^{\Psi}$ from TmTSL ${ }^{U}$ by chromatography over a mixed hydrophobic/anion exchange column (DNAPac PA200). Elution by a gradient of increasing salt yields baseline separation of the intact substrate and product stem-loop RNAs (Figure 2.7, panel B).

\section{Reaction buffer and enzyme concentration}

Phosphate buffer and Tris $\bullet \mathrm{HCl}$ buffers with $\mathrm{pH}$ ranging from $7.0-8.5$ and variable salt concentrations (100-500 mM sodium chloride or potassium chloride) were considered for the assay. TmTruB was considerably slower ( $>5$ fold) in

phosphate buffer in accord with previous results for other $\Psi$ synthases, [30] so Tris $\bullet \mathrm{HCl}$ buffer was chosen for the assay. To test the effect of salt concentration, 


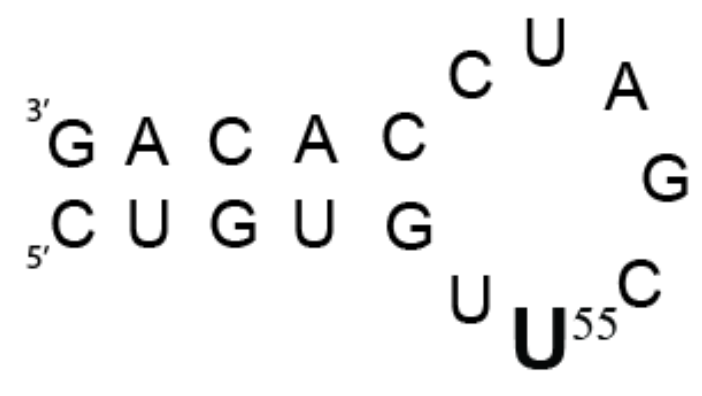

TSL from Escherichia coli tRNA ${ }^{\text {Phe }}$ (TSL)

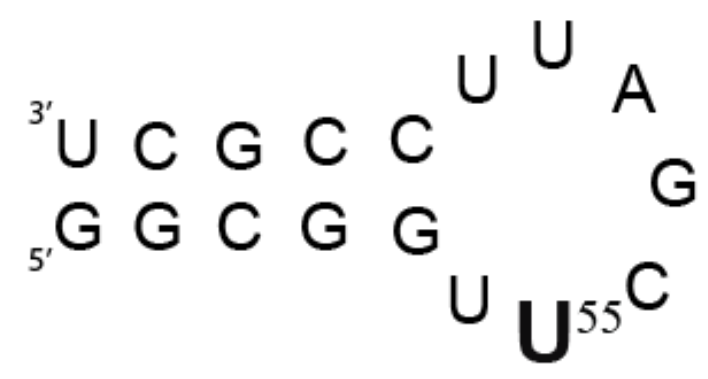

TSL from Thermus thermophilus tRNA ${ }^{\text {Phe }}$

(TtTSL)

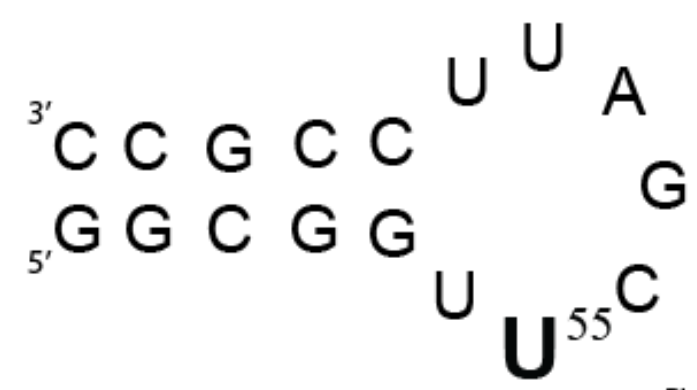

TSL from Thermotoga maritima tRNA ${ }^{\text {Phe }}$ (TmTSL)

Figure 2.6: Stem-loop RNAs tested as substrates for TmTruB. 
$A$

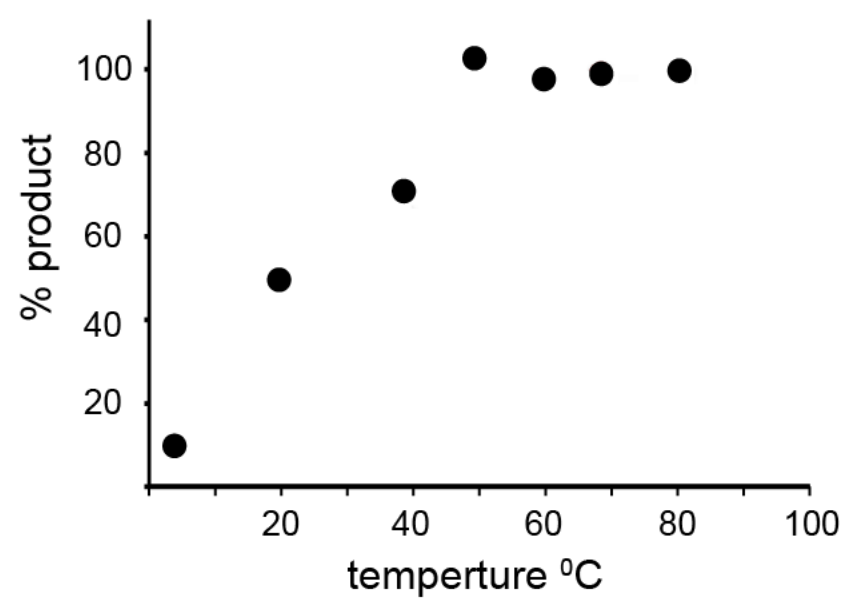

$B$

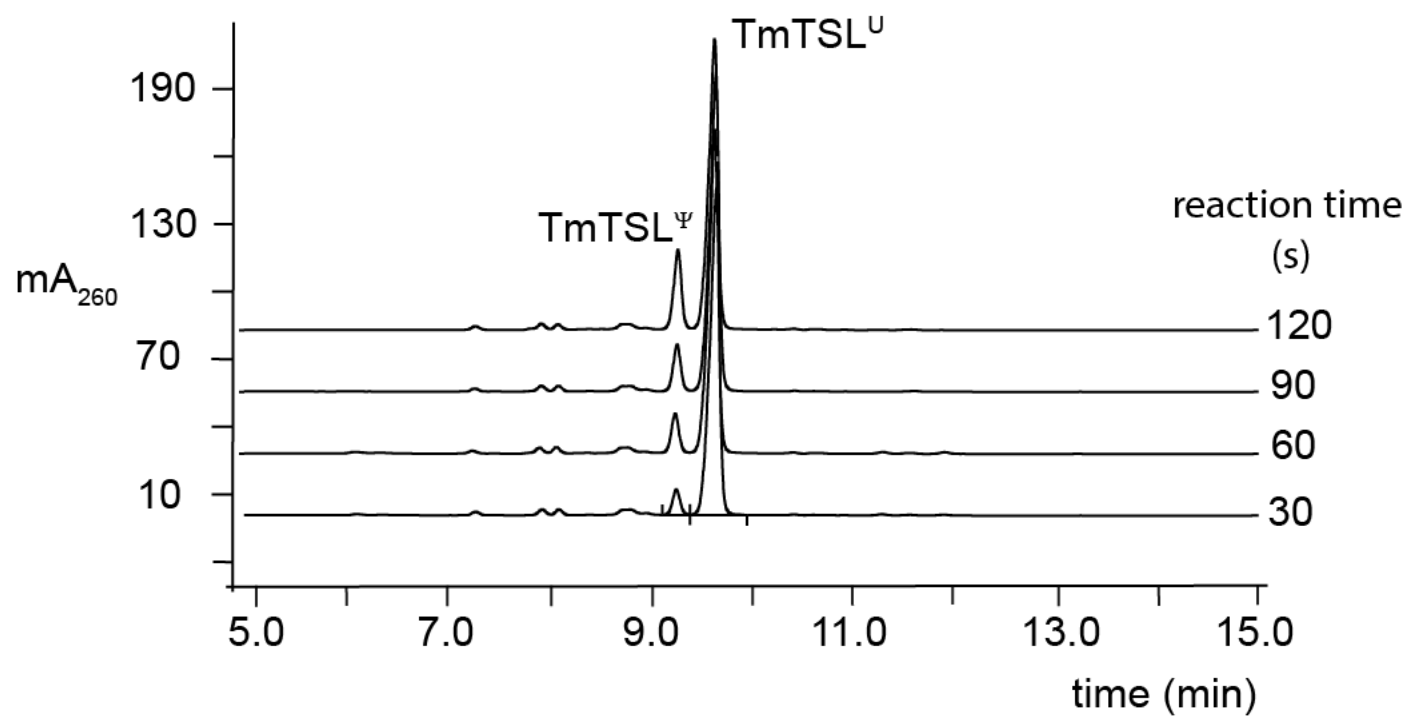

Figure 2.7: A, Endpoint (1 h) assays of the activity of TmTruB (25 nM) incubated with TmTSLU $(1 \mu \mathrm{M})$ at different temperatures. B, Time course for the reaction of $\operatorname{TmTSL}^{\mathrm{U}}(1 \mu \mathrm{M})$ catalyzed by $\operatorname{TmTruB}(5 \mathrm{nM})$ at $58^{\circ} \mathrm{C}$. 
TmTruB (1.5-25 nM) was incubated with TmTSL $(500-5000 \mathrm{nM})$ in $25 \mathrm{mM}$ Tris $\bullet \mathrm{HCl}$ buffer, $\mathrm{pH} 7.5$, containing sodium chloride $(125-500 \mathrm{mM})$. Aliquots of these reactions were withdrawn at various time intervals, and product-bearing fractions were measured for $\operatorname{TmTSL}^{\psi}$ formation. At low salt concentration (125 mM sodium chloride), the reaction was extremely fast even at low concentrations of TmTruB (complete conversion occurring within $<1 \mathrm{~min})$. TmTruB $(1.5 \mathrm{nM}$ ) was conveniently assayed at a somewhat high salt concentration $(250 \mathrm{mM})$, which was adopted as the standard reaction buffer.

\section{Steady state kinetic parameters for TmTruB}

With the various considerations addressed, the final assay described in the Experimental section was used to determine $k_{\mathrm{cat}}$ and $K_{\mathrm{m}}$ for TmTruB. Rates of $\mathrm{TmTSL}^{\psi}$ formation at variable substrate concentrations (Figure 2.8, panel A; Table

2.1) were fit to the Briggs-Haldane equation to yield $k_{\mathrm{cat}}=0.67 \pm 0.02 \mathrm{~s}^{-1}$ and $K_{\mathrm{m}}=1112 \pm 58 \mathrm{nM}$. 
Table 2.1: Initial velocity $\left(v_{0}\right)$ data for $\operatorname{TmTruB}(1.5 \mathrm{nM})$ with a range of TmTSL ${ }^{U}$ concentrations.

\begin{tabular}{|c|c|}
\hline TmTSLU, nM & $v_{0}, \mathrm{nM} \cdot \mathrm{min}^{-1}$ \\
\hline 0 & 0 \\
\hline 150 & $6.25 \pm 0.14$ \\
\hline 300 & $13.02 \pm 0.17$ \\
\hline 500 & $18.95 \pm 0.17$ \\
\hline 1000 & $28.60 \pm 1.50$ \\
\hline 2500 & $41.61 \pm 2.10$ \\
\hline
\end{tabular}




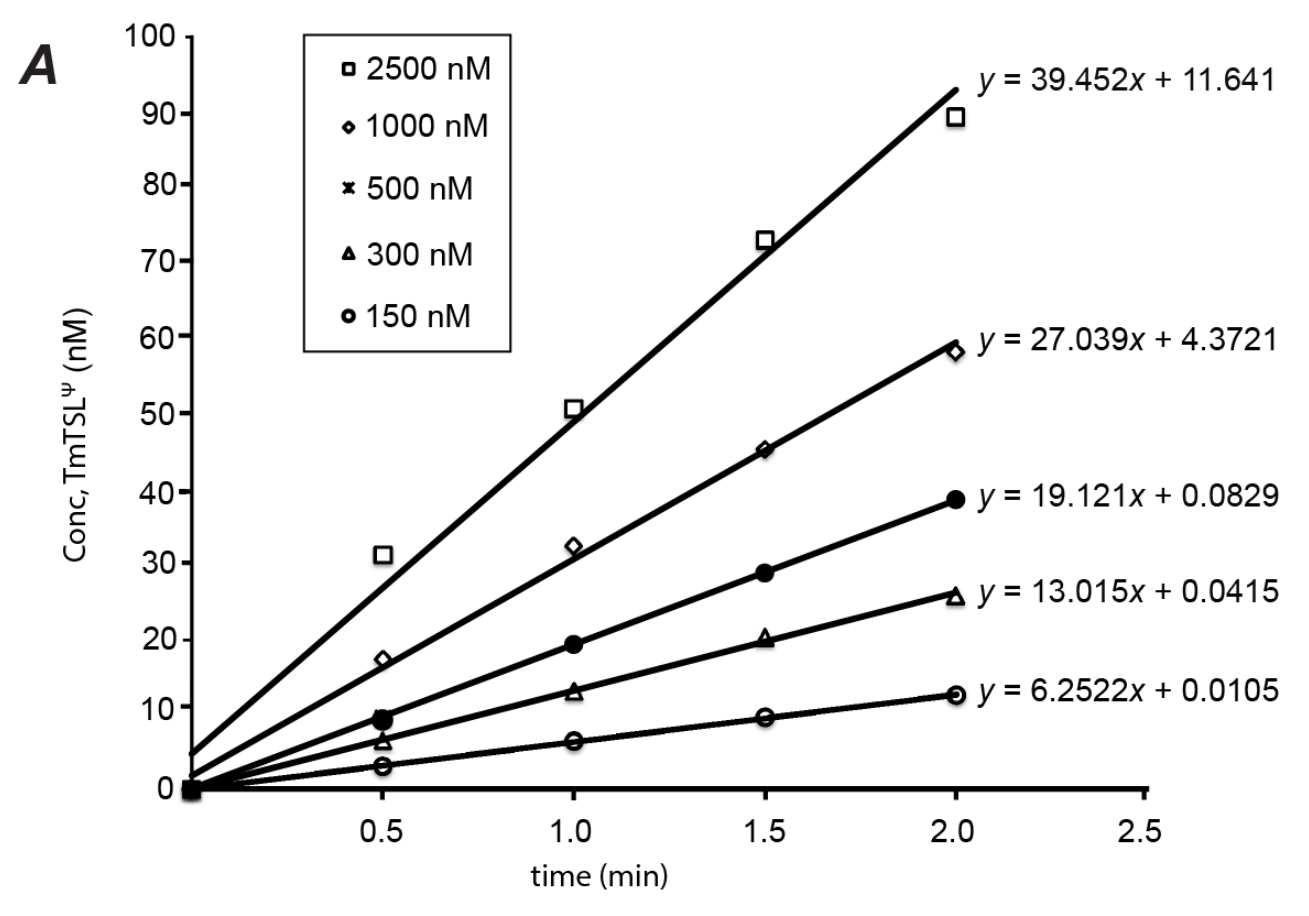

B

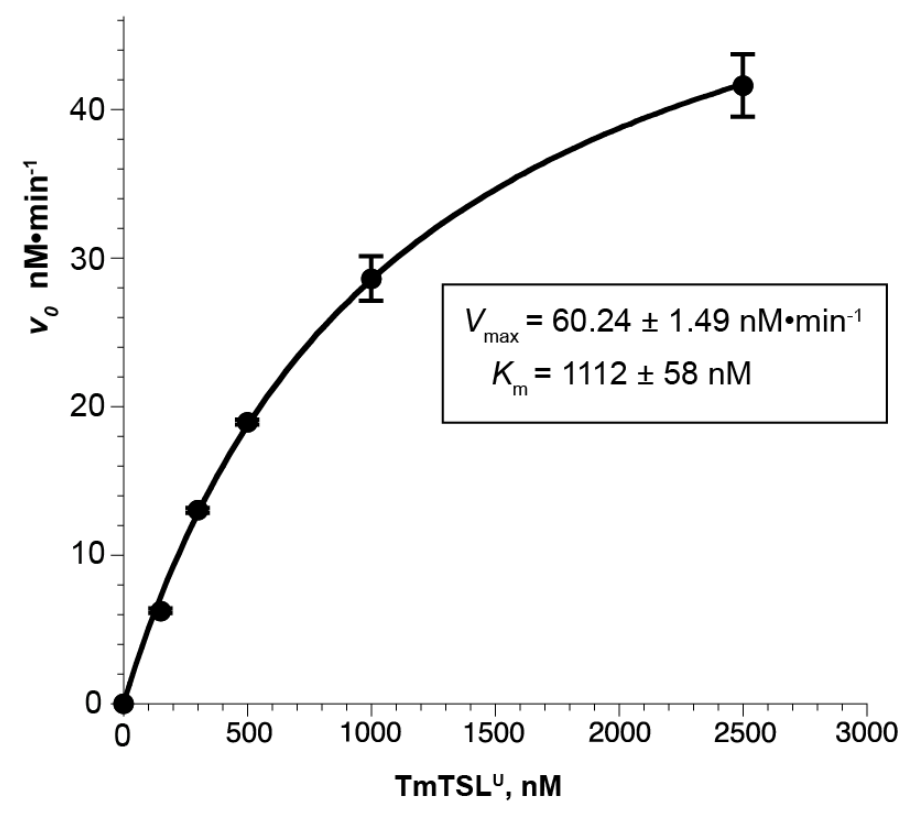

Figure 2.8: Steady state kinetic analysis of TmTruB. A, Initial velocities of TmTruB (1.5 nM) for different concentrations of TmTSLU: 2500 nM ( $\square$ ); 1000 $\mathrm{nM}(\diamond) ; 500 \mathrm{nM}(\bullet) ; 300 \mathrm{nM}(\Delta) ; 150 \mathrm{nM}(0)$. B, Fit $\left(R^{2}=0.999\right)$ of the initial velocity data for TmTruB to the Briggs-Haldane equation. 


\section{Adduct formation between TmTruB and [ $\left.\mathrm{F}^{5} \mathrm{U}\right] \mathrm{TmTSL}$}

To probe adduct formation, TmTruB $(2.5-10 \mu \mathrm{M})$ was incubated with [F5U]TmTSL $(2.5-10 \mu \mathrm{M})$ in different ratios $(1: 1,1: 2,2: 1)$ in standard reaction buffer for $3 \mathrm{~h}$ at $58{ }^{\circ} \mathrm{C}$ and were analyzed by SDS-PAGE (10\%) and urea-PAGE (12\%, $7 \mathrm{M}$ urea) gels (Figure 2.9). The gel analysis revealed a new, faster-moving adduct band that stained for both protein and RNA. SDS-PAGE analysis showed only a modest adduction ( $33 \%)$ even when TmTruB $(2.5 \mu \mathrm{M})$ was incubated with excess [F5]TmTSL $(5 \mu \mathrm{M})$. With urea-PAGE, a substantial amount of free TmTruB remained despite a consistently higher level of adduction (78\%, Figure 2.9), although substantial variation in the measured level of adduction was observed across replicate trials (Figure 2.10).

To assess product formation, TmTruB $(2.5 \mu \mathrm{M})$ was incubated with [F5]TmTSL $(5 \mu \mathrm{M})$ for $3 \mathrm{~h}$ at $58^{\circ} \mathrm{C}$. The RNA was treated with $\mathrm{S} 1$ nuclease and alkaline phosphatase, and the resulting nucleosides were analyzed by reverse phase HPLC. Peaks identical in retention time to the products of $F^{5} U$ from the action of EcTruB $\left(\mathrm{F}^{5} \mathrm{U}^{*}\right)$ confirmed the identity of the products from the action of TmTruB. To probe its inhibition by $\left[\mathrm{F}^{5} \mathrm{U}\right] \mathrm{RNA},\left[\mathrm{F}^{5} \mathrm{U}\right] \mathrm{TmTSL}(5 \mu \mathrm{M})$ was preincubated with TmTruB $(2.5 \mu \mathrm{M})$ in standard reaction buffer $(50 \mu \mathrm{L})$ for $3 \mathrm{~h}$ at 58 ${ }^{\circ} \mathrm{C}$. A small aliquot $(2.4 \mu \mathrm{L})$ of the mixture was assayed by incubation with TmTSL ${ }^{U}$ $(5 \mu \mathrm{M})$ in standard reaction buffer $(300 \mu \mathrm{L})$. Aliquots of this reaction withdrawn at various times and analyzed by HPLC revealed a substantial reduction ( 8 fold $)$ in the rate compared to untreated TmTruB (Figure 2.11). 

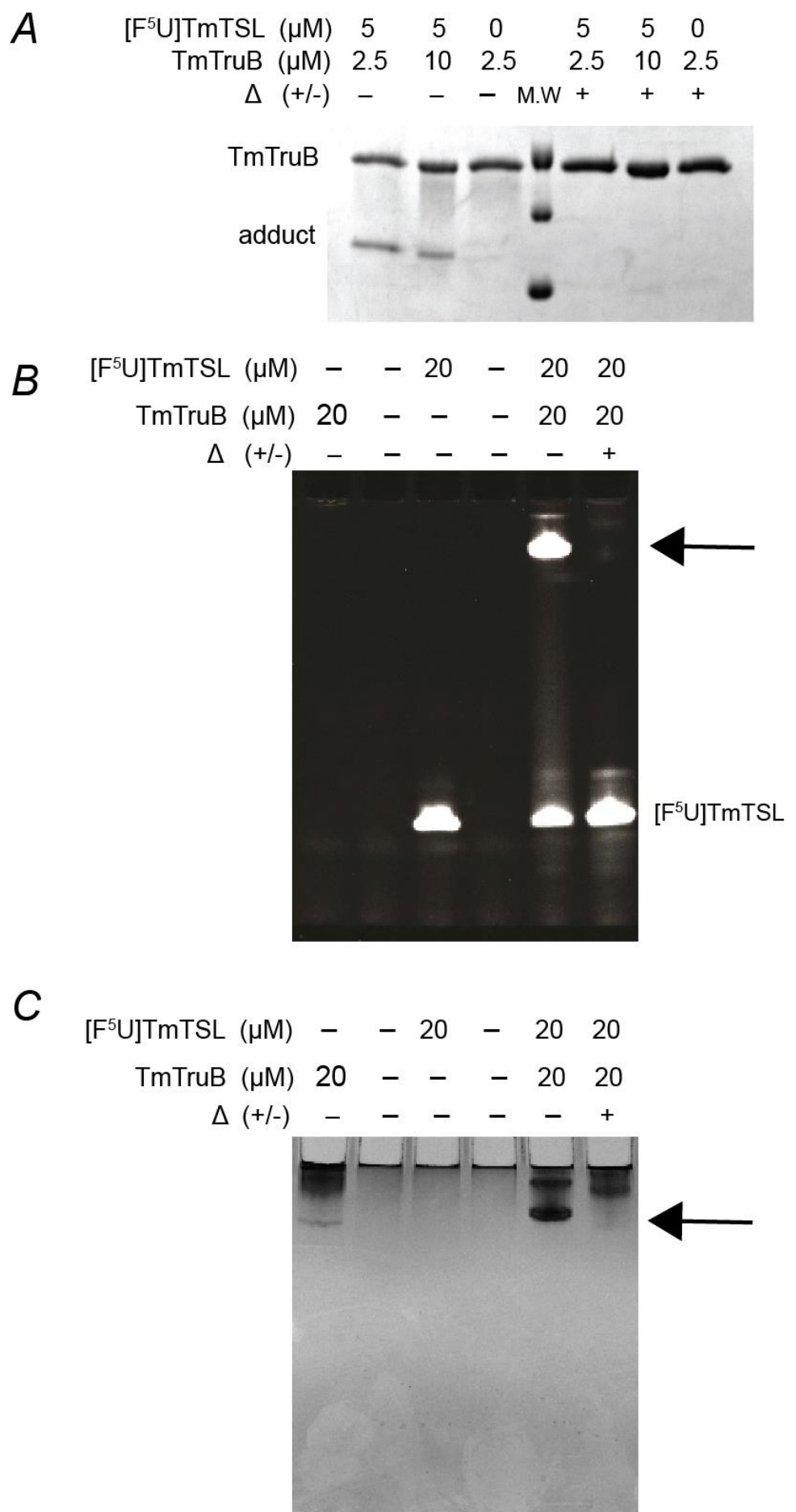

Figure 2.9: Denaturing PAGE analysis of adduct formation. A, SDS-PAGE. B, Urea-PAGE stained with SYBR ${ }^{\circledR}$ Gold. C, Urea-PAGE stained with Coomassie blue. Arrows indicate the location of the adduct. 
A

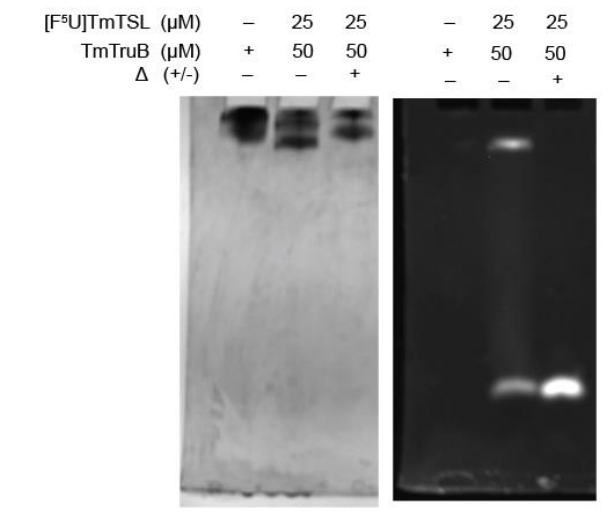

$B$

[F5]TmTSL ( $\mu$ M) $\quad 25 \quad 25 \quad 25 \quad 25$

TmTruB ( $\mu$ M) $\quad 50 \quad 50 \quad 50 \quad 50$ $\Delta(+/-)$

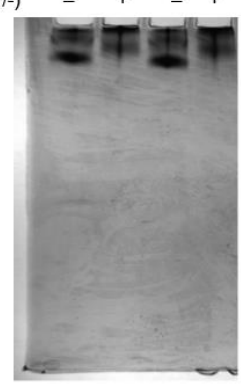

$\begin{array}{llll}25 & 25 & 25 & 25\end{array}$

$50 \quad 50 \quad 50 \quad 50$

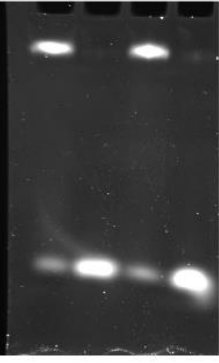

C

[F5]TmTSL $(\mu \mathrm{M})$ TmTruB $(\mu \mathrm{M})$
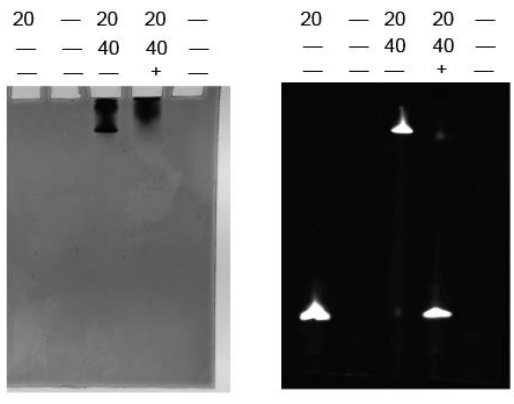

$D$

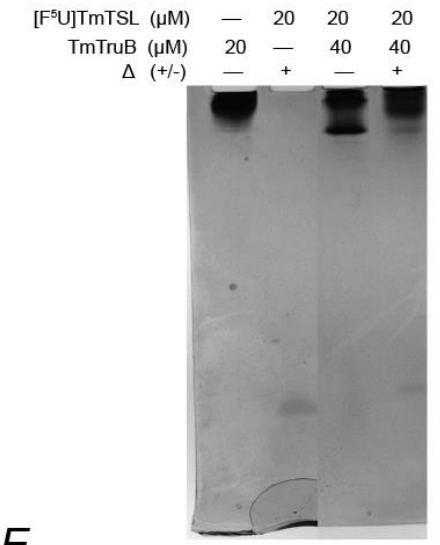

E

[F $\left.\mathrm{F}^{5} \mathrm{U}\right] \mathrm{TmTSL}(\mu \mathrm{M})$ TmTruB $(\mu \mathrm{M})$

$\Delta(+)$
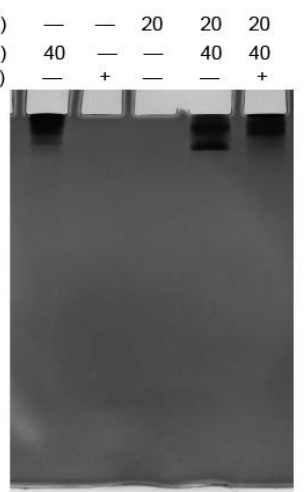

- $\quad \begin{array}{lll}20 & 2020\end{array}$

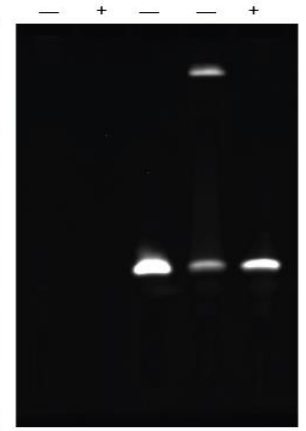

$F$

[F $\left.\mathrm{F}^{5}\right] \operatorname{TmTSL}(\mu \mathrm{M})$

TmTruB $(\mu \mathrm{M})$
$\Delta(+/-)$
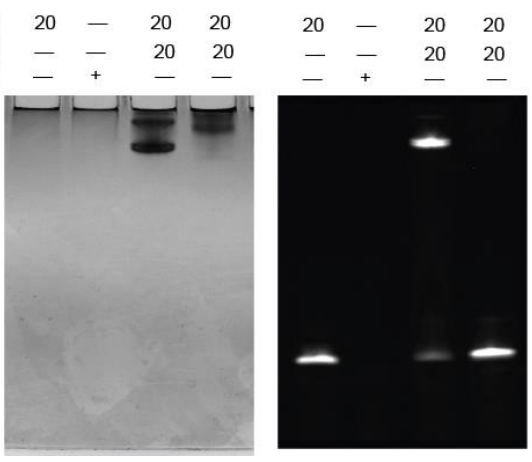

Figure 2.10: A-E, Replicates of adduction trials with TmTruB $(40 \mu \mathrm{M})$ and [ $\left.{ }^{5} \mathrm{U}\right]$ TmTSL $(20 \mu \mathrm{M})$ and analysis by urea-PAGE (15\%, 7M urea). $F$, Adduction trial with TmTruB $(20 \mu \mathrm{M})$ and $\left[\mathrm{F}^{5} \mathrm{U}\right] \mathrm{TmTSL}(20 \mu \mathrm{M})$. The quantitation of adduct, to free protein, and free RNA is summarized in Table 2.2. $5^{\prime}$-Fluorescein-labeled [ $\left.\mathrm{F}^{5} \mathrm{U}\right] \mathrm{TSL}$ was used in the experiments shown in panels $A$ and $B$; SYBR Gold was used to stain RNA in panels CF. 
Table 2.2: Changing ratios of adduct to free protein and free RNA were observed on urea-PAGE gels (Figure $2.10 ; 15 \%, 7 \mathrm{M}$ urea) for replicates of TmTruB $(40 \mu \mathrm{M})$ and $\left[\mathrm{F}^{5} \mathrm{U}\right] \mathrm{TSL}(20 \mu \mathrm{M})$ incubations.

\begin{tabular}{ccc|cc}
\hline $\begin{array}{c}\text { Reaction } \\
\text { stoichiometry, } \\
\text { (protein:RNA) }\end{array}$ & $\begin{array}{c}\text { Adduct } \\
\%\end{array}$ & $\begin{array}{c}\text { Free protein } \\
\%\end{array}$ & $\begin{array}{c}\text { Adduct } \\
\%\end{array}$ & $\begin{array}{c}\text { Free RNA } \\
\%\end{array}$ \\
\hline $2: 1$ & 52.3 & 47.7 & 39.8 & 60.2 \\
$2: 1$ & 52.6 & 47.4 & 65.4 & 34.6 \\
$2: 1$ & 53.6 & 46.4 & 67.7 & 32.3 \\
$2: 1$ & 58.4 & 41.6 & 94.8 & 5.2 \\
$2: 1$ & 63.8 & 36.2 & 95.3 & 4.7 \\
$2: 1$ & $39.8^{\mathrm{a}}$ & $60.2^{\mathrm{a}}$ & 48.5 & 51.5 \\
$1: 2$ & 54.6 & 45.4 & 76.9 & 23.1 \\
mean & 55.9 & 44.1 & 69.77 & 30.23 \\
\hline
\end{tabular}

${ }^{a}$ Outlying data excluded from the calculation of the mean. 


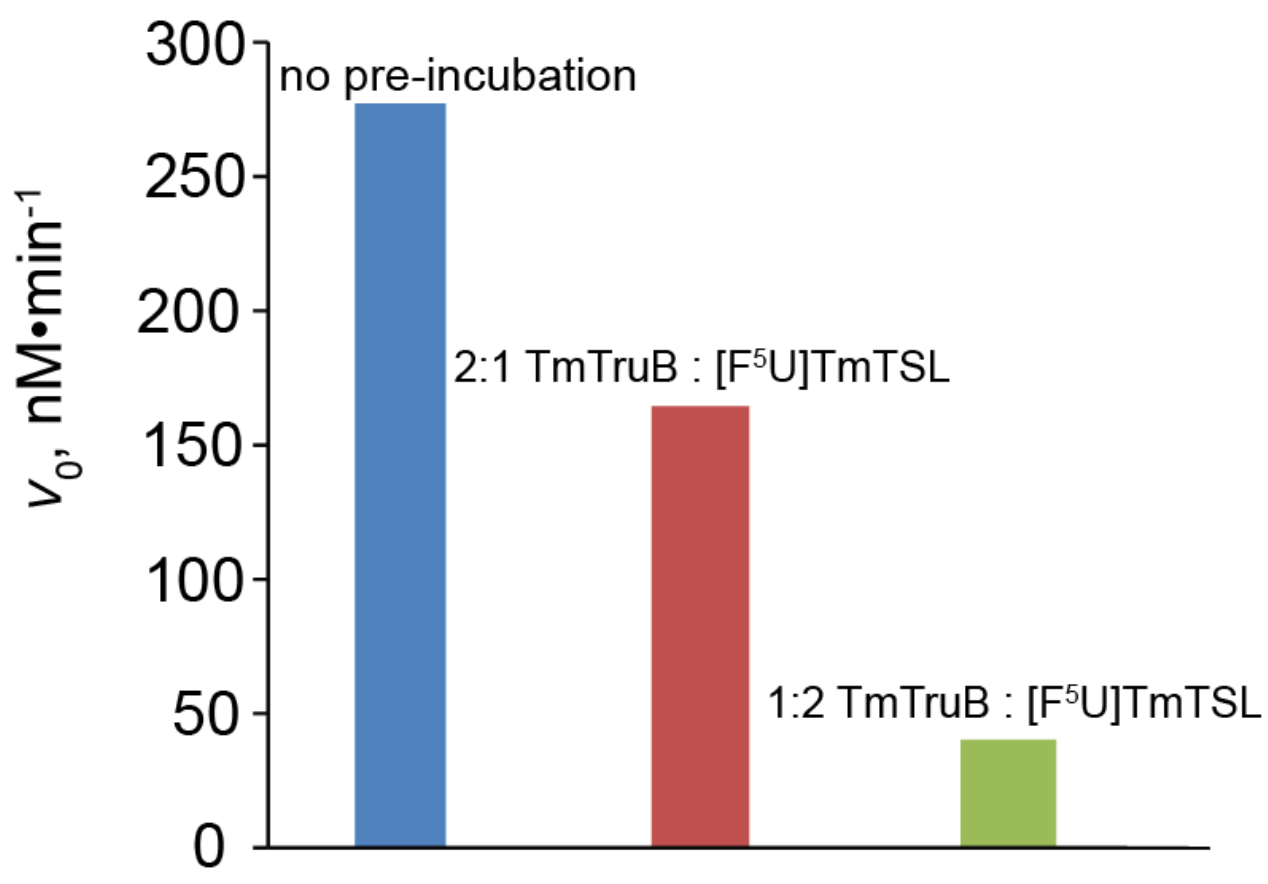

Fiqure 2.11: Inhibition of TmTruB by [ $\left.\mathrm{F}^{5} \mathrm{U}\right] \mathrm{TmTSL}$. 


\section{Size exclusion chromatography}

Size exclusion chromatography separates molecules based on their size (molecular weight, $M_{\mathrm{r}}$ ) and shape. The elution of a certain sample is usually characterized by the partition coefficient $\left(\mathrm{K}_{\mathrm{av}}\right)$, which is related to the size of the molecule (Figure 2.12). [75] Standard proteins can be used to create a calibration curve with $\mathrm{K}_{\mathrm{av}}$ plotted against $\log \left(M_{\mathrm{r}}\right)$ to determine the apparent $M_{\mathrm{r}}$ of the protein of interest. [75]

One possible explanation for substoichiometric adduct formation is a distribution between reactive and unreactive states of TmTruB. In particular, the unbound protein band on denaturing gels could arise from inactive dimer (or a higher multimeric form) of TmTruB. To probe this possibility, $M_{r}$ for TmTruB was assessed by size exclusion chromatography in both standard reaction buffer and in $50 \mathrm{mM}$ sodium phosphate buffer, $\mathrm{pH} 7.0$, containing sodium chloride (150 mM) (as recommended by the column manufacturer). Molecular weight standards were used to generate a calibration curve with which $M_{\mathrm{r}}$ for TmTruB was calculated based on its elution volume, $V_{e}$ (Figure 2.14). In phosphate buffer, the apparent molecular weight of TmTruB $(40.5 \mathrm{kDa})$ does not differ markedly from the theoretical monomeric value (37.6 kDa) (Figure 2.12, panel A), but the value in standard reaction buffer was distinctly lower $(25.0 \mathrm{kDa})$ (Figure 2.13, panel B).

Size exclusion studies were also performed on the TmTruB-[F5]RNA adduct, which was prepared by incubating TmTruB $(50 \mu \mathrm{M})$ with [ $\left.\mathrm{F}^{5} \mathrm{U}\right] \mathrm{TmTSL}$ $(50 \mu \mathrm{M})$. The free protein, free RNA, and adduct displayed very similar 


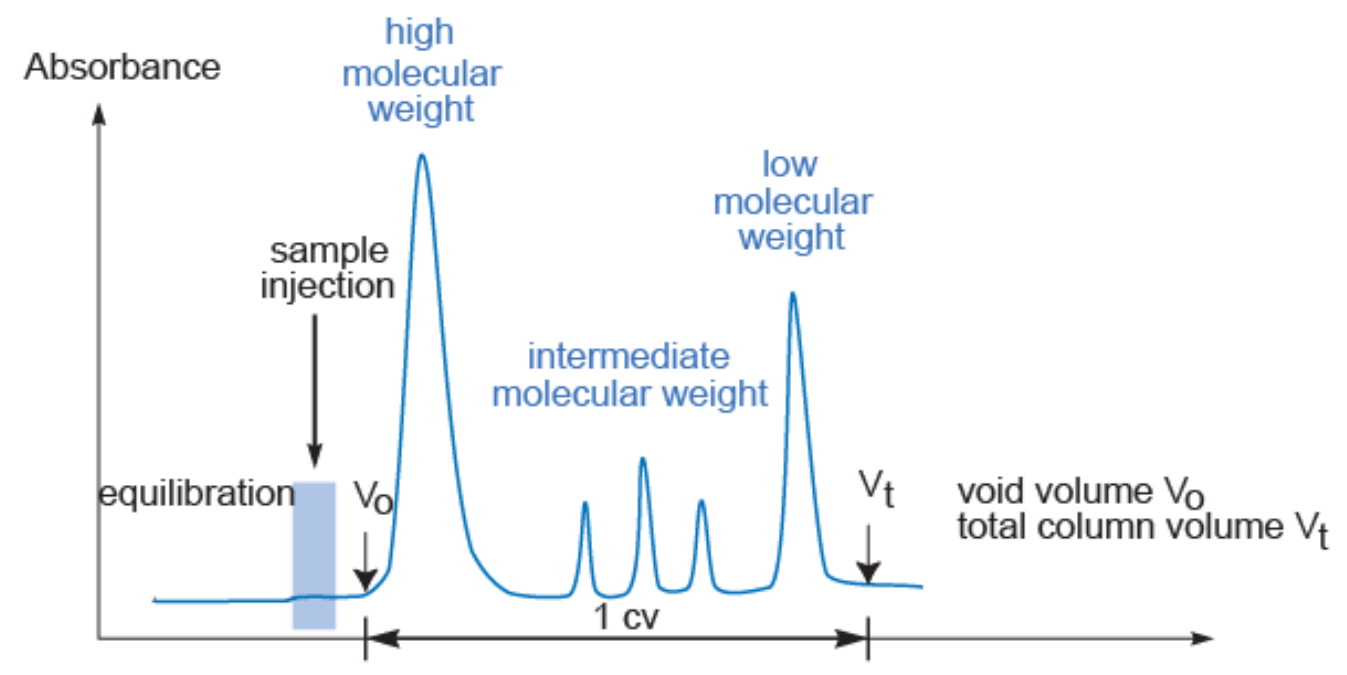

Theoretical chromatogram of a high resolution fractionation.

$$
\mathrm{K}_{\mathrm{av}}=\frac{\mathrm{V}_{\mathrm{e}}-\mathrm{V}_{0}}{\mathrm{~V}_{\mathrm{t}}-\mathrm{V}_{0}}
$$

where,

$\mathrm{V}_{\mathrm{e}}=$ elution volume for the protein

$\mathrm{V}_{\mathrm{o}}=$ column void volume $=$ elution volume for Blue Dextran

$V_{t}=$ total bed volume

Figure 2.12: Theoretical trace for size exclusion chromatography. From GE Healthcare manual 18-1022-18. 


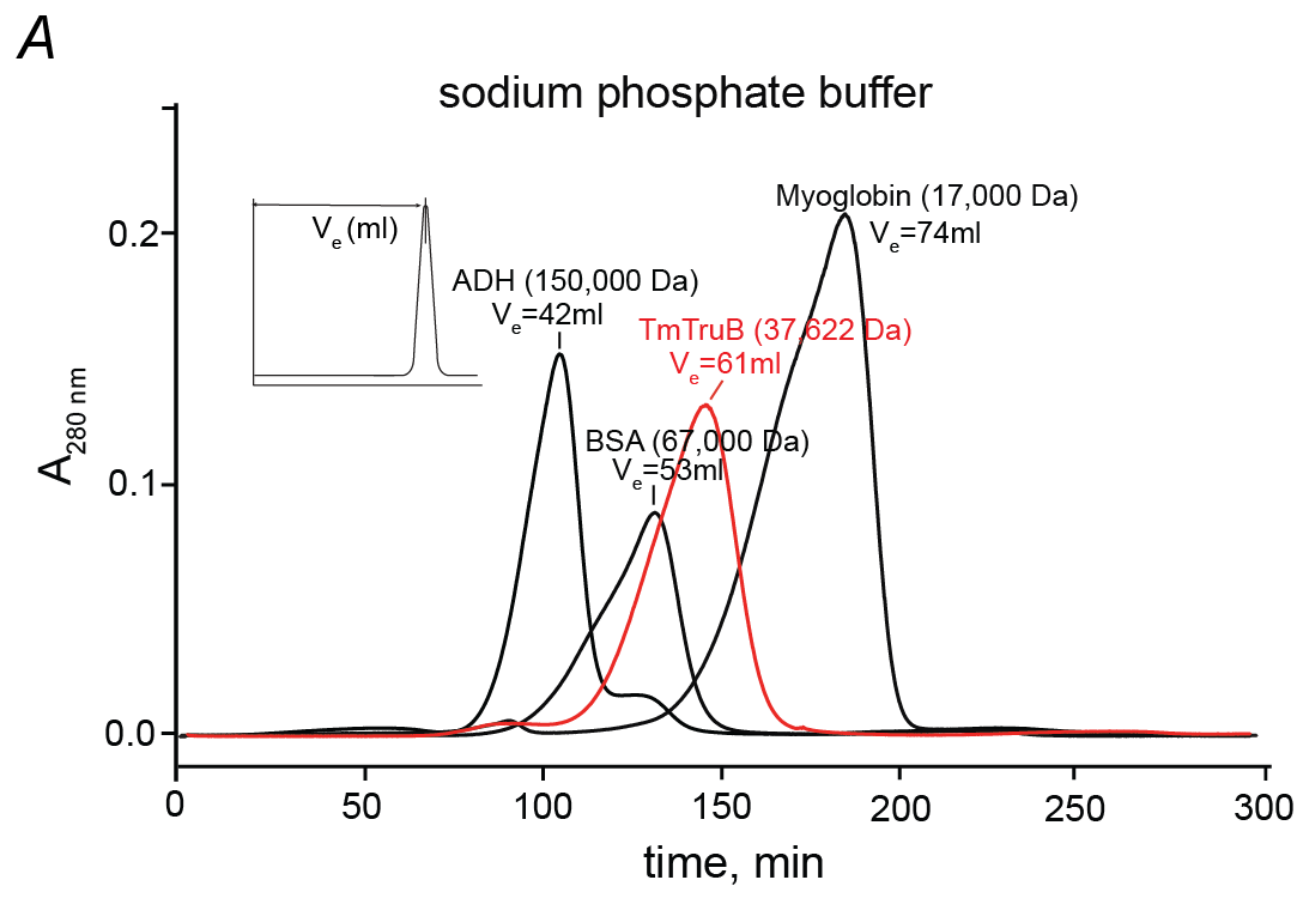

$B$

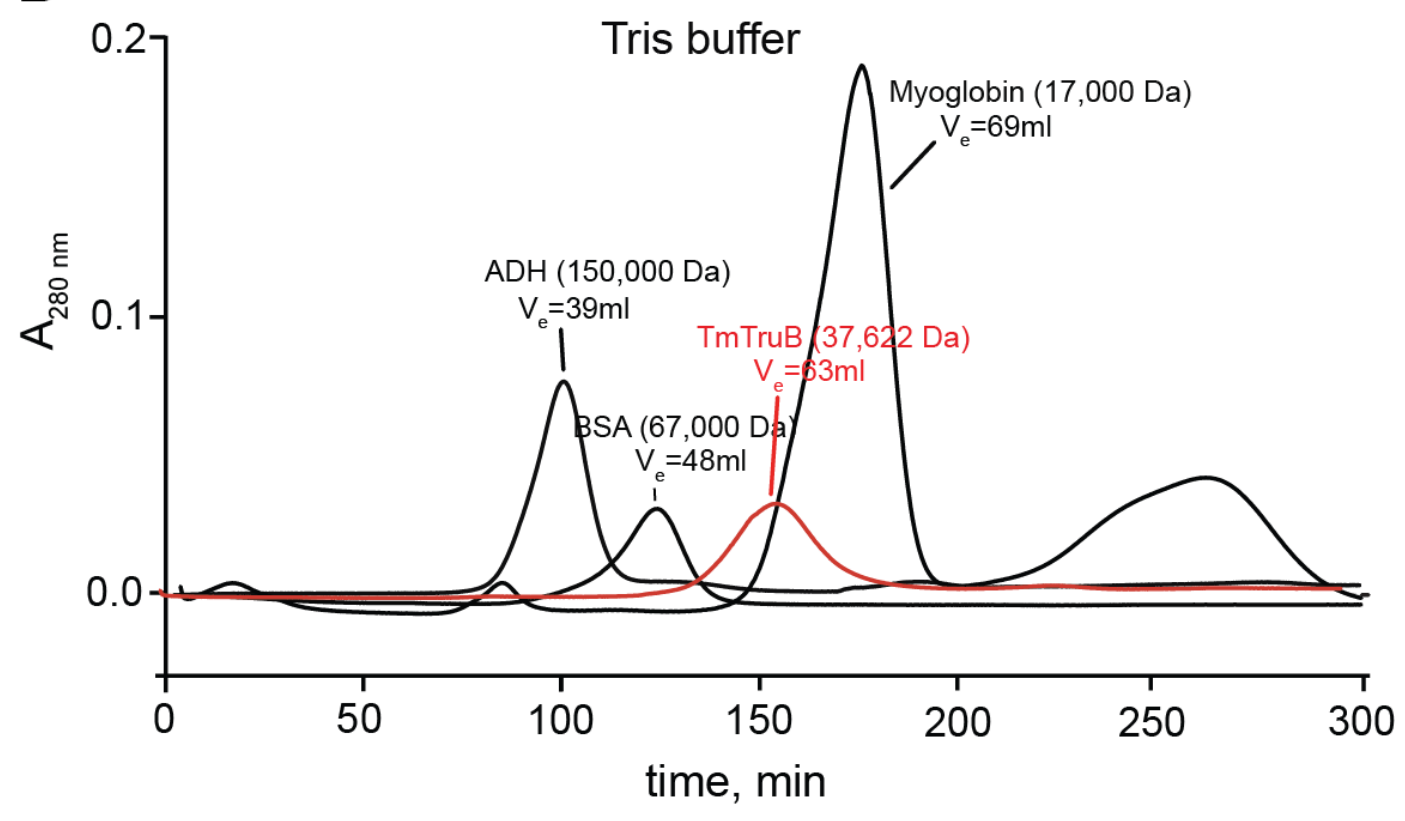

Figure 2.13: Overlay of traces from size exclusion chromatography of standards and TmTruB. A, Run in phosphate buffer. B, Run in Tris buffer. 
A sodium phosphate buffer

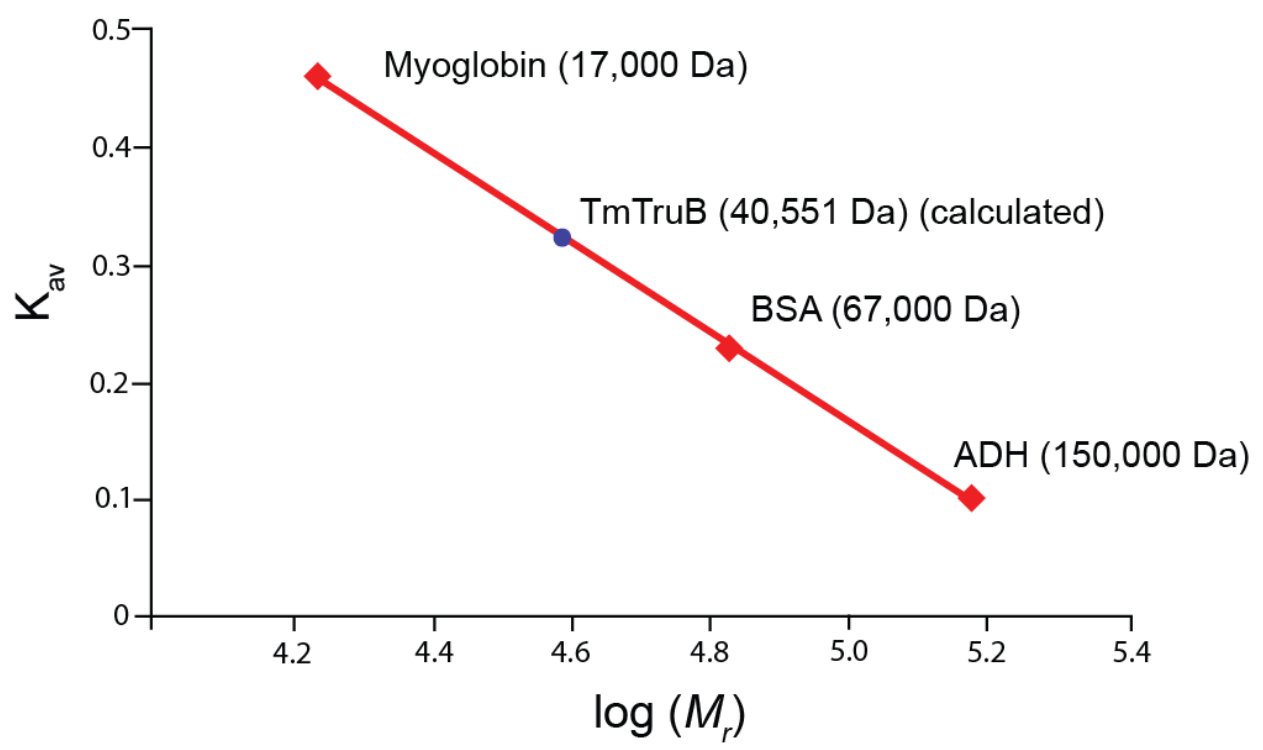

$B$

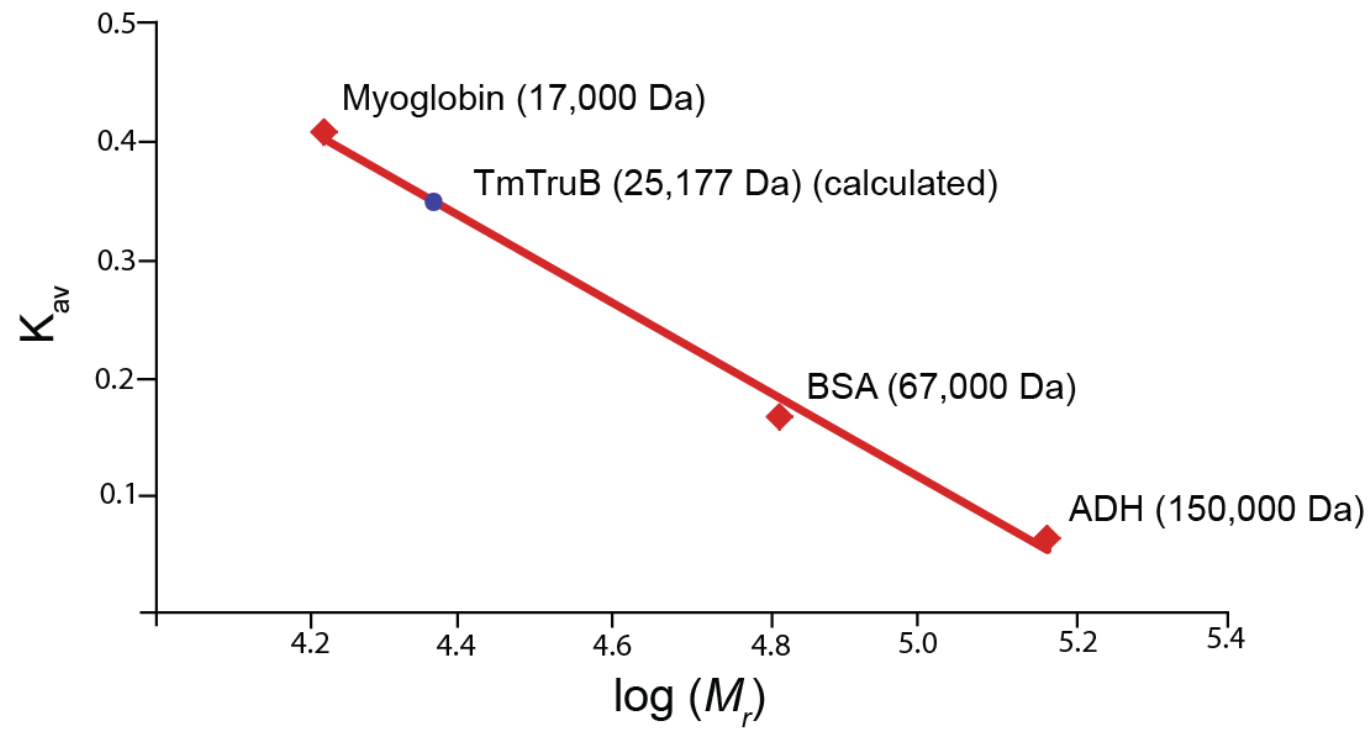

Figure 2.14: Plot of $K_{a v}$ versus $\log \left(M_{r}\right)$ for standards and TmTruB. A, Run in phosphate buffer. B, Run in Tris buffer. 
displayed very similar $\mathrm{V}_{\mathrm{e}}(62 \mathrm{~mL}, 64 \mathrm{~mL}$, and $58 \mathrm{~mL}$, respectively; Figure 2.15), making it very difficult to differentiate the adduct from free RNA and protein. Denaturing PAGE analysis of the eluted fractions $(42-70 \mathrm{~mL})$ from the run with the adduct showed free TmTruB, free RNA, and the adduct, which suggests co-elution (Figure 2.16).

\section{Time course for the formation of $\left[F^{5} U^{\star}\right] T m T S L$}

The size exclusion chromatography results seem to disfavor the hypothesis that an inactive TmTruB dimer accounts for the free protein seen by denaturing PAGE, which raises the possibility that some fraction of TmTruB is simply incapable of interacting with [ $\left.\mathrm{F}^{5} \mathrm{U}\right] \mathrm{RNA}$ because of some unknown posttranslational event. To address this question, TmTruB $(5 \mu \mathrm{M})$ was incubated with an excess of $\left[\mathrm{F}^{5} \mathrm{U}\right] \mathrm{TmTSL}(50 \mu \mathrm{M})$, and the ratio of adduct to free protein was monitored over time by urea-PAGE. This analysis revealed surprisingly fast adduct formation, with $\sim 50 \%$ of TmTruB in the adduct form by the time first aliquot was withdrawn (5 min), the ratio of adduct to free protein and RNA slowly increased over the course of $3 \mathrm{~h}$ (Table 2.3; Figure 2.16). In apparent contradiction, the HPLC analysis revealed $>90 \%$ conversion of $\left[\mathrm{F}^{5} \mathrm{U}\right] \mathrm{TmTSL}$ into its hydrated product, a level that held constant and which requires more than 9 turnovers by each active site; the first turnover occurred within 5 min (Figure 2.17). 
$A$

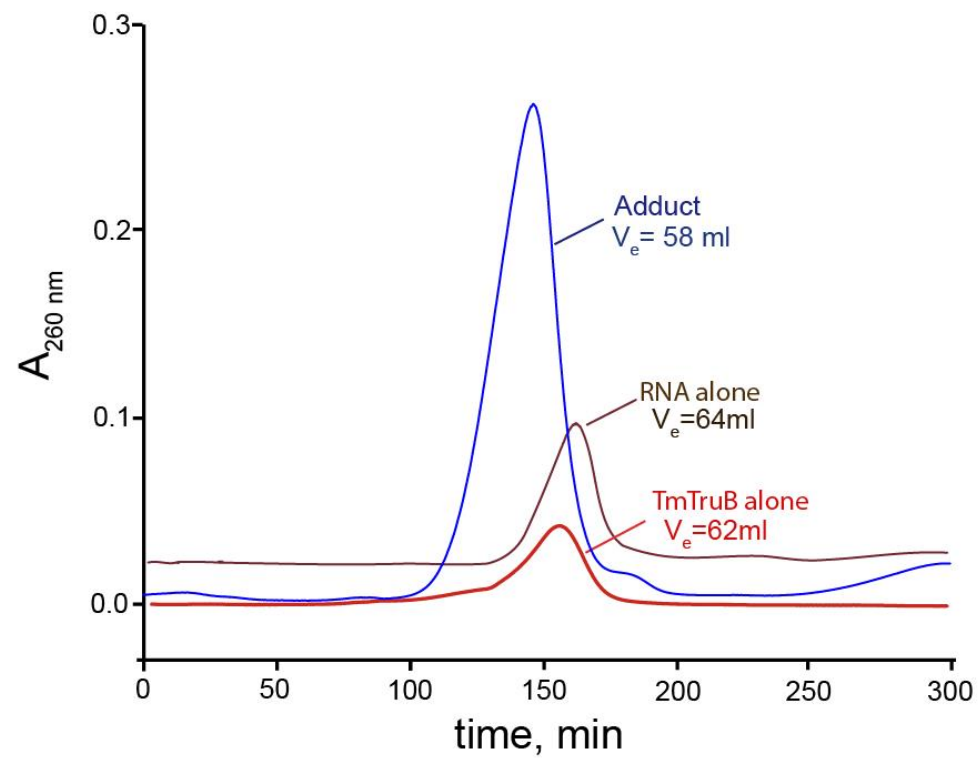

B

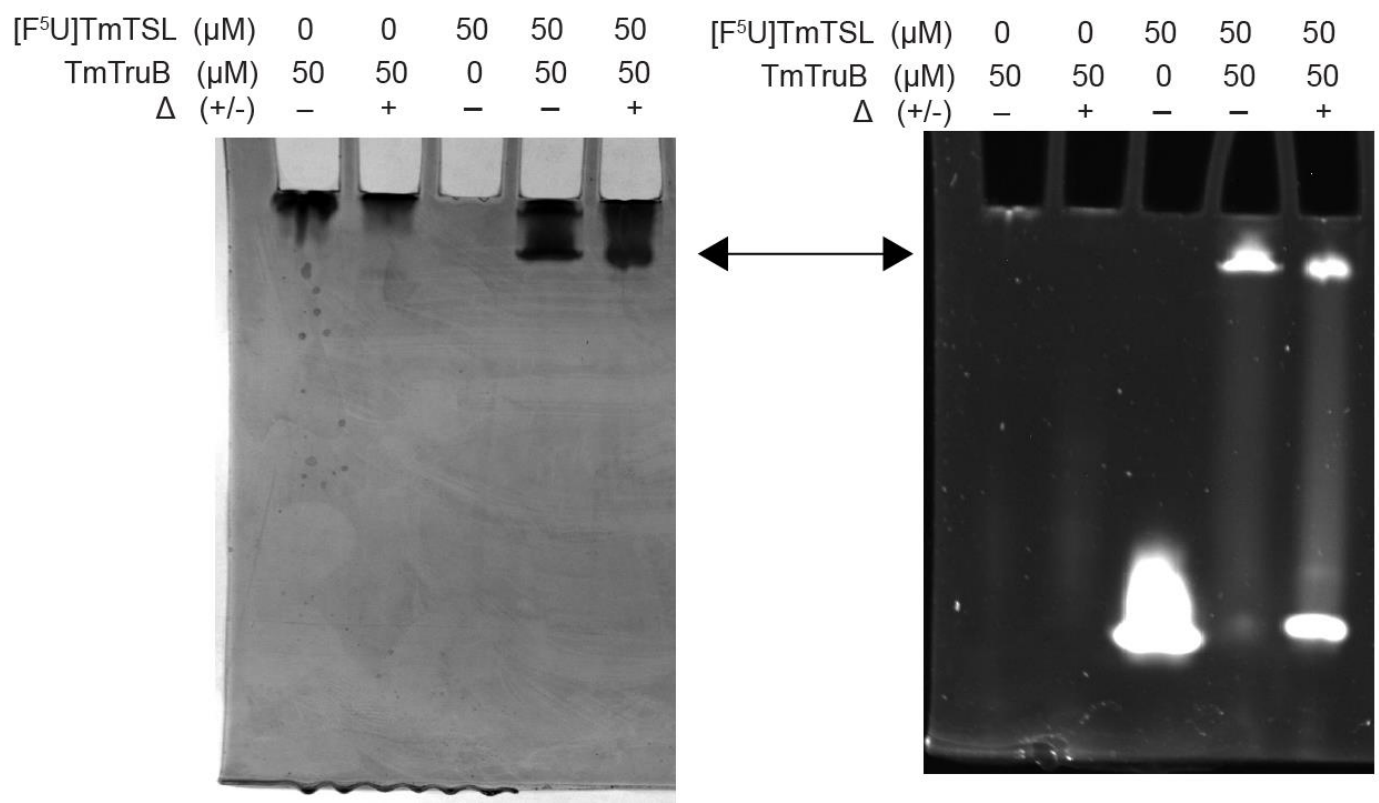

Figure 2.15: Size exclusion chromatography studies of the TmTruB[F5]TmTSL adduct. A, Traces of the adduct, free TmTruB, and free $\left[\mathrm{F}^{5} \mathrm{U}\right] \mathrm{TmTSL}$. $\mathrm{B}$, Gel analysis showing that all $\left[\mathrm{F}^{5} \mathrm{U}\right] \mathrm{TmTSL}$ is adducted before the size exclusion run. 
Table 2.3: Distribution of adduct, free TmTruB, and free $\left[\mathrm{F}^{5} \mathrm{U}\right] \mathrm{TmTSL}$ by urea-PAGE for the time course of the formation of the TmTruB[F $\left.{ }^{5} \mathrm{U}\right] \mathrm{TmTSL}$ adduct.

\begin{tabular}{ccccc} 
& \multicolumn{2}{c}{ TmTruB } & \multicolumn{2}{c}{ [F5]TmTSL } \\
\hline time, min & adduct, \% & free protein, \% & adduct, \% & free RNA, \% \\
\hline 0 & 0 & 100 & 0 & 100 \\
5 & 48.1 & 51.9 & 68.4 & 31.6 \\
10 & 46.4 & 53.6 & 67.5 & 32.5 \\
30 & 59.4 & 40.6 & 80.7 & 19.3 \\
60 & 64.4 & 35.6 & 87.5 & 12.5 \\
120 & 64.6 & 35.4 & 74.6 & 25.4 \\
180 & 77.9 & 22.1 & 91.0 & 9.0 \\
\hline
\end{tabular}




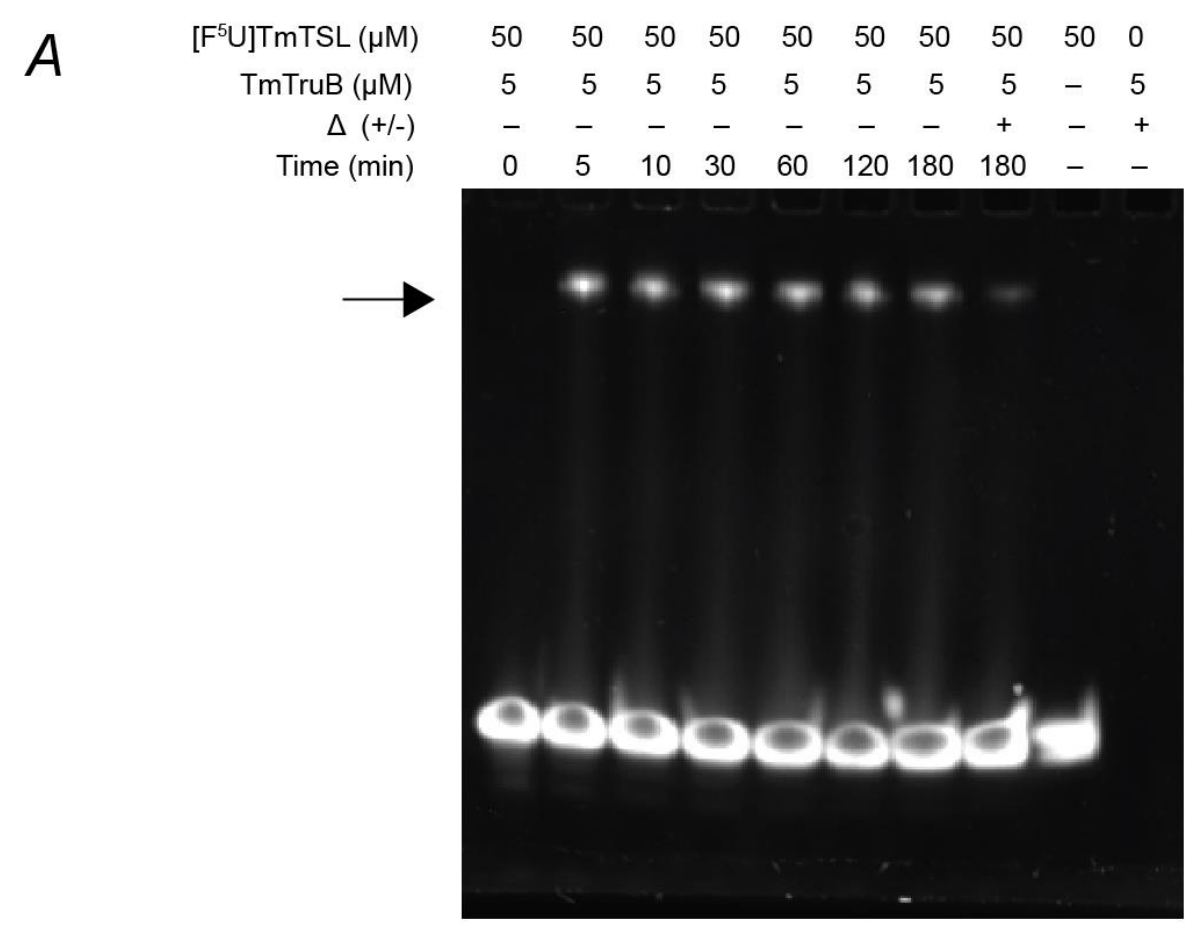

B

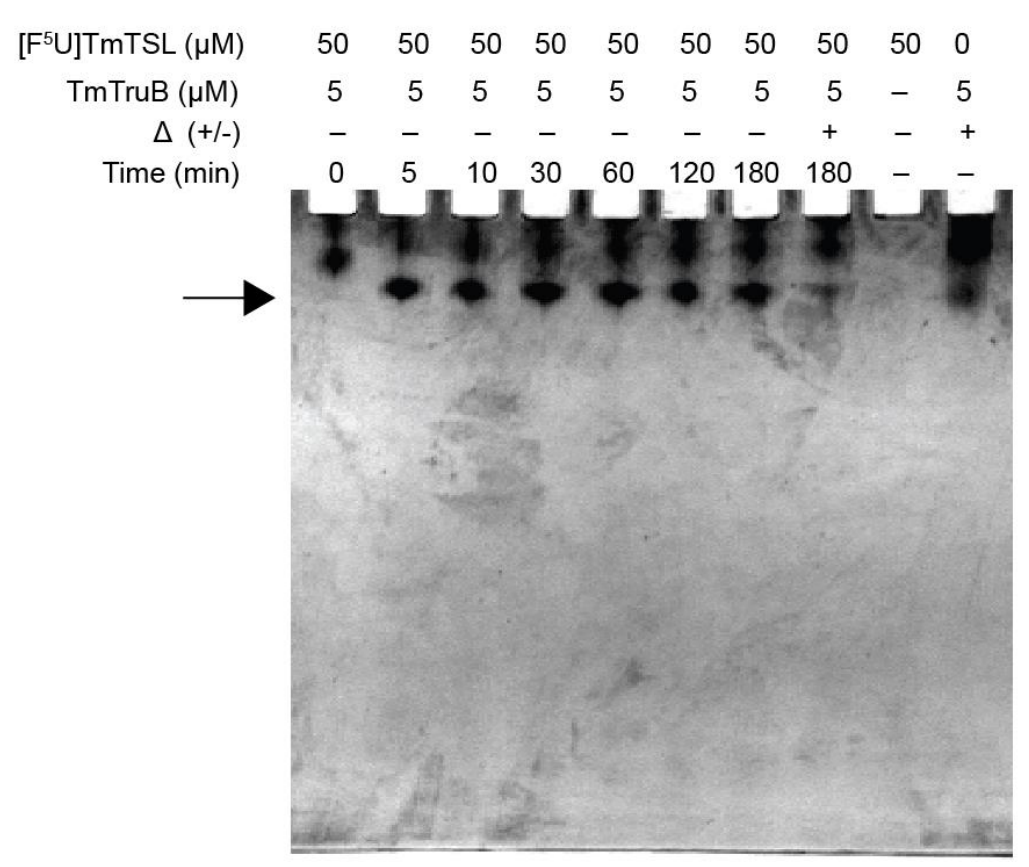

Figure 2.16: Urea-PAGE (12\%, 7M urea) analysis of the reaction between TmTruB $(5 \mu \mathrm{M})$ and $\left[\mathrm{F}^{5} \mathrm{U}\right] \mathrm{TmTSL}(50 \mu \mathrm{M})$. A, The gel was stained with SYBR $^{\circledR}$ Gold to visualize RNA. B, The same gel was then stained with Coomassie blue stain to visualize protein. Arrows indicate the location of the adduct. 

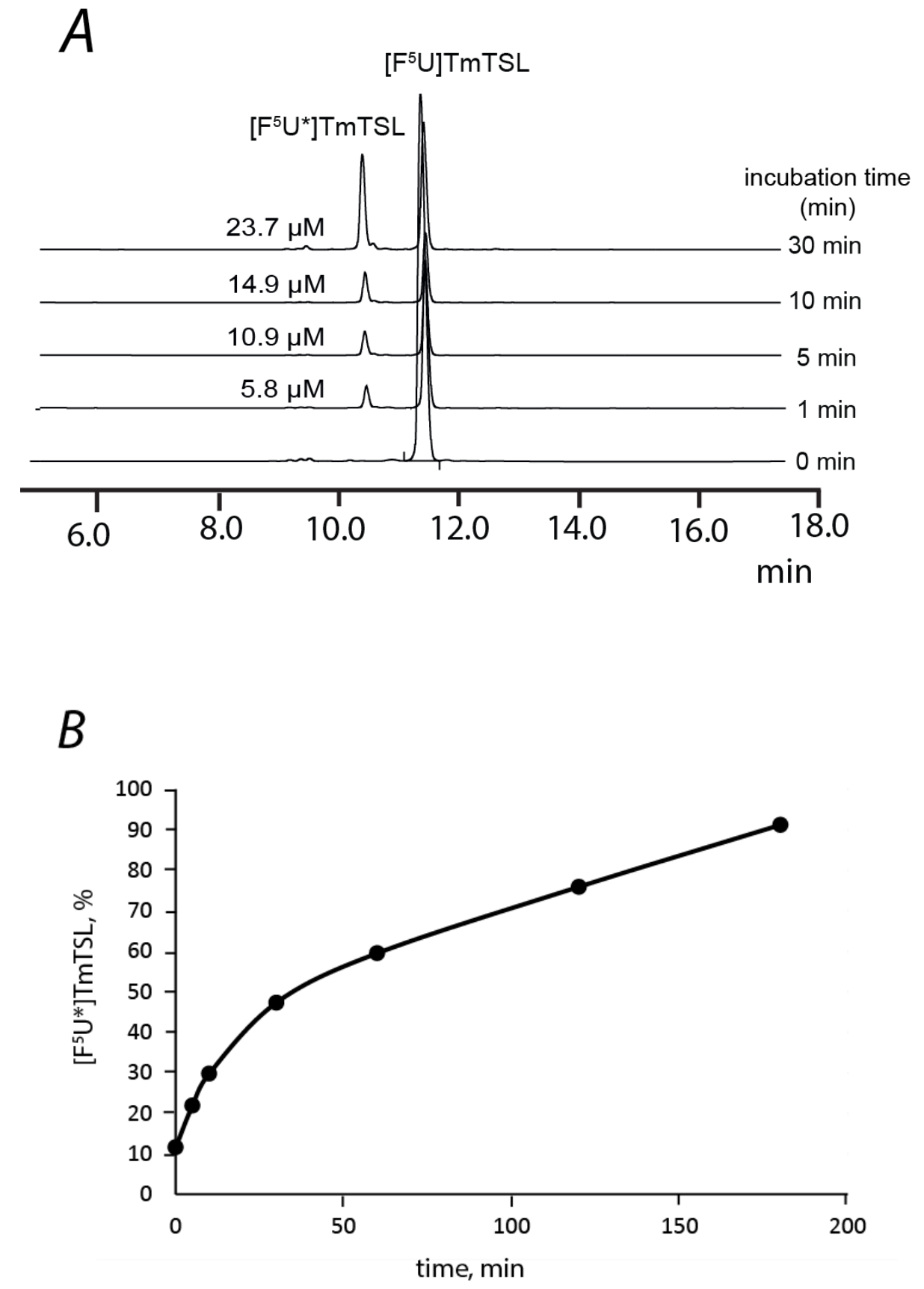

Figure 2.17: Time course for the conversion of [ $\left.{ }^{5} \mathrm{U}\right] \mathrm{TmTSL}(50 \mu \mathrm{M})$ upon incubation with TmTruB $(5 \mu \mathrm{M})$. A, HPLC traces showing the increase in $F^{5} U^{*}$ with time. B, Plot showing the amount of $\left[F^{5} U^{*}\right] T m T S L$ as a percentage of total RNA. 


\section{${ }^{18} \mathrm{O}$ labeling studies}

\section{Characterization of TmTruB and [ $\left.\mathrm{F}^{5} \mathrm{U}\right] \mathrm{TmTSL}$ by mass spectrometry}

Monitoring ${ }^{18} \mathrm{O}$ incorporation into RNA or protein by mass spectrometry requires a clear window in the mass spectrum. An overlap of the peptide containing Asp-39 with other peptides would interfere with the detection of ${ }^{18} \mathrm{O}$ incorporation, and the digestion of product RNA provides isotopic resolution and improved sensitivity.

Different proteolytic enzymes and digestion conditions were tried to get peptides containing the conserved Asp (Asp-39) in a clear window. The proteolytic digestion of thermophilic TmTruB proved extremely difficult as the enzyme resisted proteolysis by trypsin, chymotrypsin, endoproteinase-GluC, or pepsin under conventional conditions. Denaturation of TmTruB prior to proteolytic digestion using guanidinium chloride, trichloroacetic acid, or urea also failed to deliver suitable digestion. Ultimately, the combination of trypsin and endoproteinase GluC (hereafter "trypsin/Glu-C") yielded two peptides that matched the expected mass of proteolytic fragments containing Asp-39. The identity of these peptides could not be confirmed by MS/MS methods, probably due to inadequate sensitivity and the hydrophobicity of these peptides. [76] To confirm the identity of the putative peptides containing Asp-39, D39A TmTruB was overexpressed, purified, and subjected to trypsin/Glu-C digestion. The expected shift of $39 \mathrm{Da}$ for the peptides confirmed their identity (Figure 2.18). For [ $\left.\mathrm{F}^{5} \mathrm{U}\right] \mathrm{TmTSL}$, digestion with RNase $\mathrm{T} 1^{3}$

\footnotetext{
${ }^{3}$ RNase T1 specifically cleaves RNA after the nucleotide $G$.
} 
delivered the oligonucleotide containing $\mathrm{F}^{5} \mathrm{U}$ in a clear mass spectral window $\left(\mathrm{U}\left[\mathrm{F}^{5} \mathrm{U}\right] \mathrm{CG}, 1219.23\right.$ monoisotopic mass; Figure 2.20, panel A). For the trypsin/Glu-C digestions, sequence coverages of $73 \%$ and $89 \%$ were observed, respectively, for wild-type TmTruB (Table 2.4) and D39A TmTruB (Table 2.5).

\section{Controls for ${ }^{18} \mathrm{O}$ exchange}

Control experiments were run to exclude the exchange of the ${ }^{18} \mathrm{O}$ label between Asp-39 and the solvent molecules on the timescale of reaction workup and mass spectral acquisition. An aliquot $(10 \mu \mathrm{L})$ of TmTruB digested with trypsin/Glu-C was mixed with $\left[{ }^{18} \mathrm{O}\right]$ water $(10 \mu \mathrm{L})$ and incubated for $3 \mathrm{~h}$ at room temperature prior to analysis. Also, an aliquot $(3 \mu \mathrm{L})$ of the trypsin/Glu-C digestion of TmTruB was mixed with $\mathrm{Cl}-\mathrm{CCA}$ matrix solution $(3 \mu \mathrm{L})$ made with $\left[{ }^{18} \mathrm{O}\right]$ water $(50 \%, v / v)$ and analyzed. These control experiments showed no incorporation of ${ }^{18} \mathrm{O}$ into the peptides containing Asp-39, thereby excluding the possibility of oxygen exchange with solvent under the reaction conditions and analysis. To ensure the isotopic content of the $\left[{ }^{18} \mathrm{O}\right]$ water and assure that methods are sufficiently sensitive to detect ${ }^{18} \mathrm{O}$ incorporation, TmTruB was digested with trypsin/Glu-C in $25 \mathrm{mM}$ sodium phosphate buffer, $\mathrm{pH} 7.8$, containing $\left[{ }^{18} \mathrm{O}\right]$ water $(50 \%, \mathrm{v} / \mathrm{v})$ and analyzed. As expected, ${ }^{18} \mathrm{O}$ was incorporated into the $\mathrm{C}$-termini of proteolytically-generated peptides (Figure 2.19, panel C).

Similar control experiments were performed with $\left[\mathrm{F}^{5} \mathrm{U}\right] \mathrm{TmTSL}$. To eliminate the possibility of ${ }^{18} \mathrm{O}$ exchange with solvent on the timescale of RNA isolation and workup, RNase T1-digested and dephosphorylated [ $\left.\mathrm{F}^{5} \mathrm{U}^{*}\right] \mathrm{TmTSL}(10 \mu \mathrm{L})$ was 


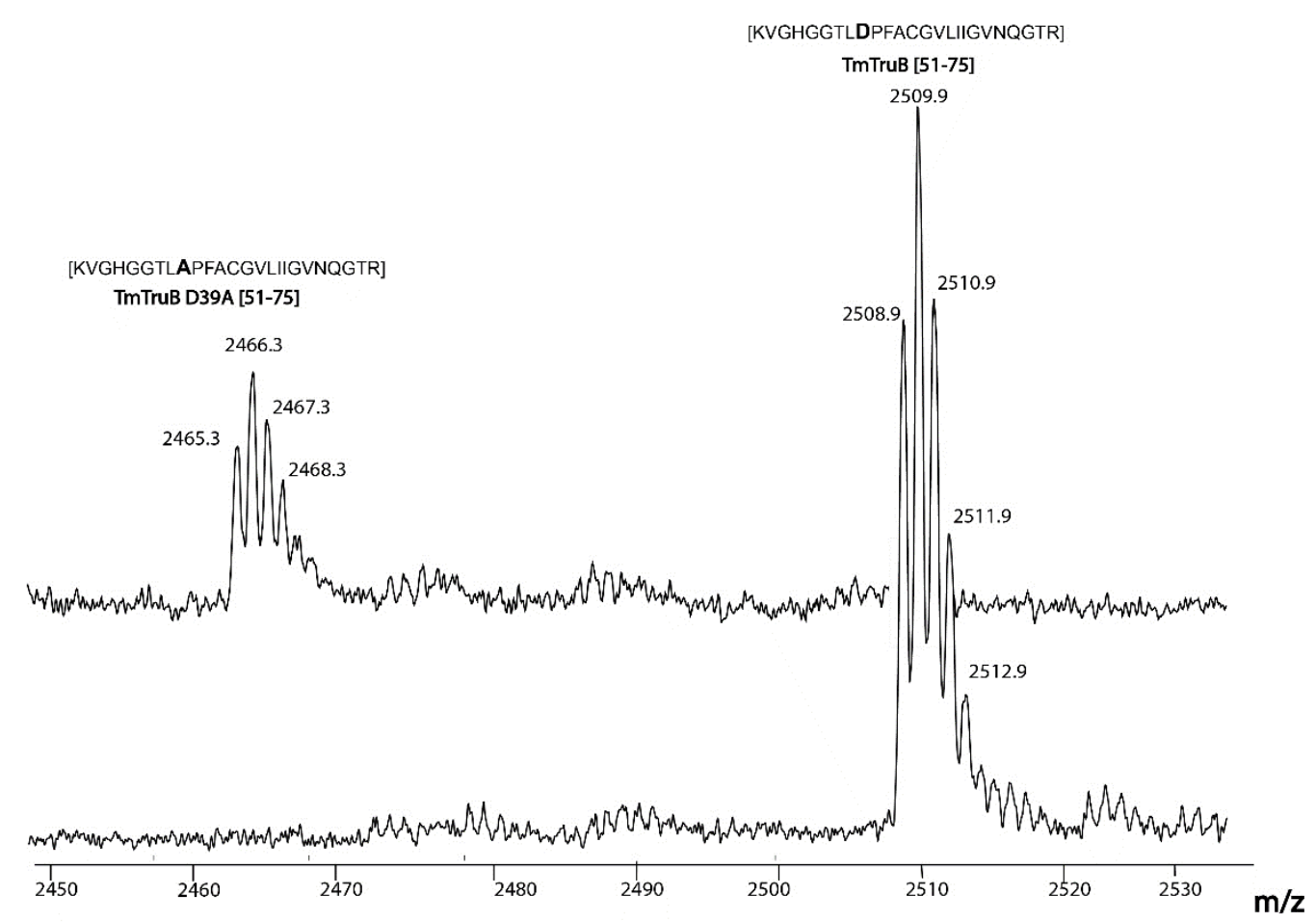

Figure 2.18: Partial mass spectrum of the trypsin/Glu-C digestion peptides from TmTruB showing the peptide containing Asp-39 $\left({ }^{32}\right.$ KVGHGGTLDPFACGVLIIGVNQGTR $\left.{ }^{55}\right)$. Lower spectrum, wild-type (2509.33 $\left.\mathrm{m} / \mathrm{z}_{\text {pred; }} 2508.9 \mathrm{~m} / \mathrm{z}_{\text {obsd }}\right)$; upper spectrum, D39A (2465.34 $\mathrm{m} / \mathrm{z}_{\text {pred; }}$; $\left.2465.3 \mathrm{~m} / \mathrm{Z}_{\text {obsd }}\right)$. 
Table 2.4: Sequence coverage for the trypsin/Glu-C digest of wild-type TmTruB.

\begin{tabular}{|c|c|c|}
\hline peptide & $\mathrm{m} / \mathrm{z}_{\text {predicted }}$ & $\mathrm{m} / \mathrm{z}_{\text {observed }}$ \\
\hline VLTLR & 601.40 & 601.11 \\
\hline DVSFR & 623.31 & 623.20 \\
\hline LLALAE & 629.39 & 629.01 \\
\hline VFNTR & 636.35 & 636.12 \\
\hline LGLITE & 645.38 & 645.04 \\
\hline LAREGK & 673.40 & 673.20 \\
\hline RVLTLR & 757.50 & 757.34 \\
\hline KVFNTR & 764.44 & 764.33 \\
\hline IINLPPK & 794.51 & 794.31 \\
\hline VVDEVRK & 844.49 & 844.23 \\
\hline DVSFRV & 851.43 & 851.27 \\
\hline AIFSFVGE & 869.44 & 869.21 \\
\hline IWDVNIE & 888.44 & 888.09 \\
\hline VSPGTYIR & 892.49 & 892.26 \\
\hline IINLPPKR & 950.61 & 950.46 \\
\hline ESVGPHTIE & 968.47 & 968.31 \\
\hline LLALAEAER & 985.57 & 985.43 \\
\hline GRDVSFRVE & 1064.54 & 1064.40 \\
\hline NSSFLETLR & 1066.55 & 1066.48 \\
\hline LYKLAREGK & 1077.64 & 1077.41 \\
\hline IWDVNIEGR & 1101.57 & 1101.41 \\
\hline HGILVAYKPK & 1125.68 & 1125.68 \\
\hline ILEFYKDLK & 1168.66 & 1168.50 \\
\hline RNSSFLETLR & 1222.65 & 1222.41 \\
\hline YDQVPPAYSAK & 1238.61 & 1238.46 \\
\hline MILNGSQIHLE & 1254.65 & 1254.49 \\
\hline EAIFSFVGEYD & 1276.57 & 1276.48 \\
\hline LKTRKVGHGGTLD & 1381.79 & 1381.63 \\
\hline SLNVFEAAPEEIE & 1447.69 & 1447.51 \\
\hline IFKIWDVNIEGR & 1489.82 & 1489.70 \\
\hline PFACGVLIIGVNQGTR & 1644.89 & 1644.61 \\
\hline LLALAEAERNSSFLE & 1662.87 & 1662.81 \\
\hline GSSHHHHHHSSGLVPR & 1768.85 & 1768.64 \\
\hline GRLLALAEAERNSSFLE & 1875.99 & 1875.83 \\
\hline HGILVAYKPKGPTSHDVVD & 2033.08 & 2033.18 \\
\hline AIFSFVGEYDQVPPAYSAK & 2089.03 & 2088.79 \\
\hline LGCGATAVELVRESVGPHTIE & 2267.13 & 2266.90 \\
\hline VGHGGTLDPFACGVLIIGVNQGTR & 2381.23 & 2380.89 \\
\hline KVGHGGTLDPFACGVLIIGVNQGTR & 2509.33 & 2508.95 \\
\hline GSHMKHGILVAYKPKGPTSHDVVDE & 2702.37 & 2701.86 \\
\hline
\end{tabular}


Table 2.5: Sequence coverage for the trypsin/Glu-C digest of D39A TmTruB.

\begin{tabular}{|c|c|c|}
\hline peptide & $m / z_{\text {predicted }}$ & $m / z_{\text {observed }}$ \\
\hline VLTLR & 601.40 & 601.15 \\
\hline DVSFR & 623.31 & 623.16 \\
\hline VFNTR & 636.35 & 636.11 \\
\hline LGLITE & 645.38 & 645.01 \\
\hline WDGFK & 652.31 & 652.13 \\
\hline LAREGK & 673.40 & 673.10 \\
\hline RVLTLR & 757.50 & 757.31 \\
\hline KVFNTR & 764.44 & 764.24 \\
\hline IINLPPK & 794.51 & 794.28 \\
\hline DVSFRV & 851.43 & 851.25 \\
\hline AIFSFVGE & 869.44 & 869.14 \\
\hline IWDVNIE & 888.44 & 888.09 \\
\hline VSPGTYIR & 892.49 & 892.19 \\
\hline IINLPPKR & 950.61 & 950.36 \\
\hline ESVGPHTIE & 968.47 & 968.21 \\
\hline EGRLLALAE & 971.55 & 971.34 \\
\hline LLALAEAER & 985.57 & 985.30 \\
\hline VVRVFNEE & 991.52 & 991.20 \\
\hline SLCMDIGYK & 1029.47 & 1029.22 \\
\hline GPTSHDVVDE & 1055.46 & 1055.19 \\
\hline GRDVSFRVE & 1064.54 & 1064.40 \\
\hline NSSFLETLR & 1066.55 & 1066.28 \\
\hline LYKLAREGK & 1077.64 & 1077.20 \\
\hline IWDVNIEGR & 1101.57 & 1101.26 \\
\hline HGILVAYKPK & 1125.68 & 1125.38 \\
\hline AIFSFVGEYD & 1147.53 & 1147.40 \\
\hline ILEFYKDLK & 1168.66 & 1168.35 \\
\hline RNSSFLETLR & 1222.65 & 1222.40 \\
\hline YDQVPPAYSAK & 1238.61 & 1238.35 \\
\hline MILNGSQIHLE & 1254.65 & 1254.42 \\
\hline WLPRVVVHQE & 1262.70 & 1262.47 \\
\hline EAIFSFVGEYD & 1276.57 & 1276.35 \\
\hline IGYKLGCGATAVE & 1281.65 & 1281.35 \\
\hline VNIEGRDVSFR & 1291.68 & 1291.36 \\
\hline LKTRKVGHGGTLD & 1381.79 & 1381.51 \\
\hline SLNVFEAAPEEIE & 1447.69 & 1447.37 \\
\hline IFKIWDVNIEGR & 1489.82 & 1489.70 \\
\hline TFDITGEVVEERE & 1523.72 & 1523.50 \\
\hline EVVEERECNVTEE & 1564.68 & 1564.64 \\
\hline PFACGVLIIGVNQGTR & 1644.89 & 1644.61 \\
\hline LLALAEAERNSSFLE & 1662.87 & 1662.81 \\
\hline GSSHHHHHHSSGLVPR & 1768.85 & 1768.87 \\
\hline RNERVLTLRKVFNTR & 1902.11 & 1902.23 \\
\hline SVGPHTIEESLVNVFEAAPE & 2025.97 & 2026.17 \\
\hline AIFSFVGEYDQVPPAYSAK & 2089.03 & 2088.75 \\
\hline LGCGATAVELVRESVGPHTIE & 2267.13 & 2266.90 \\
\hline VGHGGTLDPFACGVLIIGVNQGTR & 2337.25 & 2337.31 \\
\hline KVGHGGTLDPFACGVLIIGVNQGTR & 2465.34 & 2465.30 \\
\hline GSHMKHGILVAYKPKGPTSHDVVDE & 2702.37 & 2702.49 \\
\hline
\end{tabular}


mixed with $\left[{ }^{18} \mathrm{O}\right]$ water $(10 \mu \mathrm{L})$, incubated for $3 \mathrm{~h}$ at room temperature, and analyzed. To eliminate the possibility of ${ }^{18} \mathrm{O}$ exchange between solvent and RNA during mass spectral acquisition, an aliquot ( $3 \mu \mathrm{L})$ of the RNase T1-digested and dephosphorylated $\left[\mathrm{F}^{5} \mathrm{U}^{*}\right] \mathrm{TmTSL}$ was mixed with 3 -HPA matrix solution $(3 \mu \mathrm{L})$ made with $\left[{ }^{18} \mathrm{O}\right]$ water $(50 \%, \mathrm{v} / \mathrm{v})$. The mass spectra showed no incorporation of ${ }^{18} \mathrm{O}$ into the $\mathrm{F}^{5} \mathrm{U}^{\star}$ containing oligonucleotide (or any others).

\section{TmTruB}

Once the control experiments delivered satisfactory outcomes, TmTruB (10 $\mu \mathrm{M})$ was incubated with $\left[\mathrm{F}^{5} \mathrm{U}\right] \mathrm{TmTSL}(40 \mu \mathrm{M})$ in standard reaction buffer $(250 \mu \mathrm{L})$ made with $\left[{ }^{18} \mathrm{O}\right]$ water $(50 \%, \mathrm{v} / \mathrm{v})$ for $3 \mathrm{~h}$ at $58{ }^{\circ} \mathrm{C}$, and the reaction mixture was heated for $15 \mathrm{~min}$ at $94{ }^{\circ} \mathrm{C}$ to disrupt the adduct. After centrifugation, the supernatant was removed, and the pelleted TmTruB was resuspended, digested with trypsin/Glu-C, mixed with $\mathrm{Cl}-\mathrm{CCA}$ matrix solution, and analyzed. If ester hydrolysis occurs and ${ }^{18} \mathrm{O}$ gets incorporated into the Asp-39 containing peptide, the isotopic composition for this peptide should match that of the reaction buffer $\left(50 \%{ }^{18} \mathrm{O}\right)$. Instead, the mass spectrum for this labeled reaction (Figure 2.19, panel B) is identical to the reaction run in unlabeled buffer (Figure 2.19, panel A). 


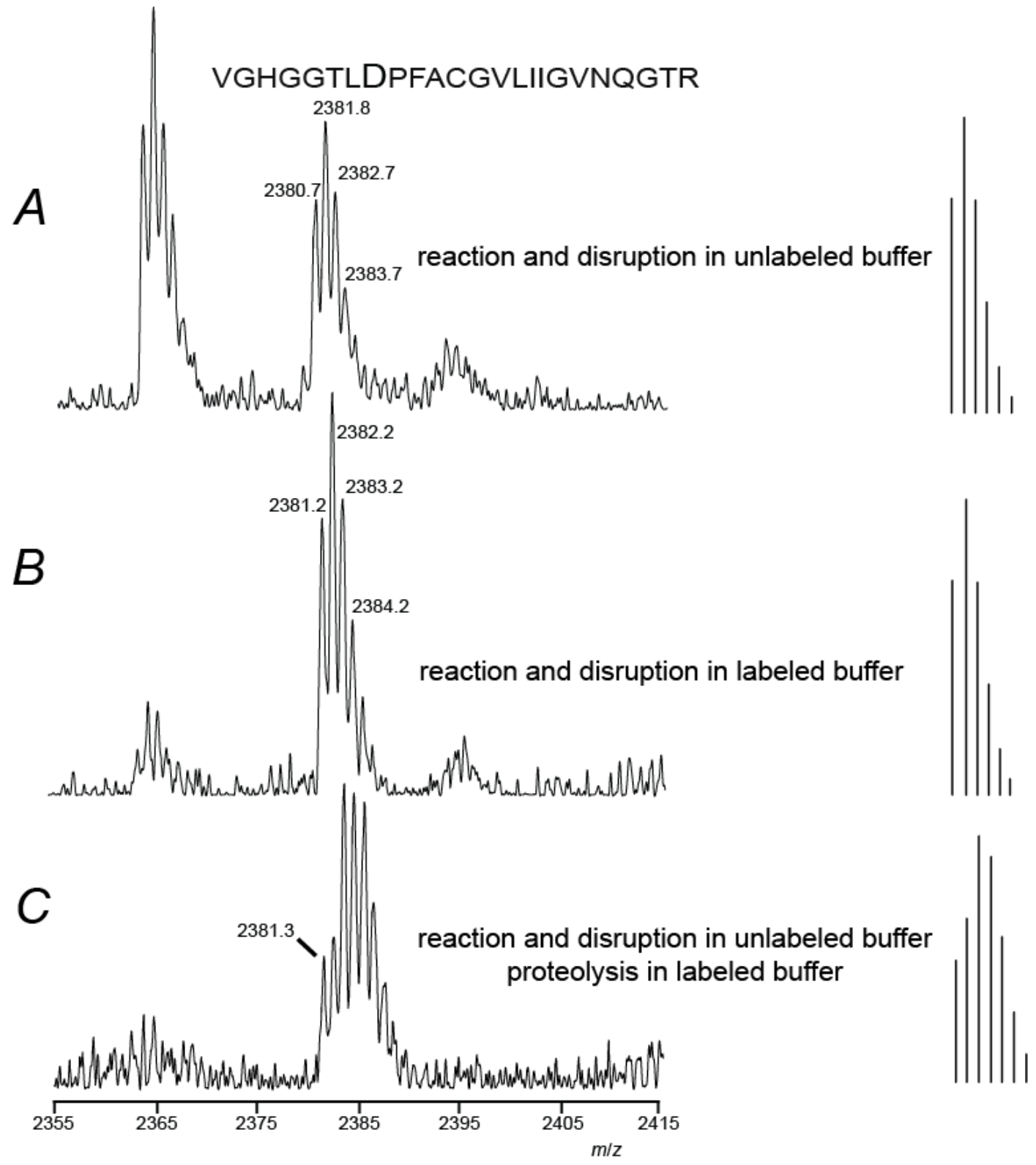

Figure 2.19: Partial mass spectra of trypsin/Glu-C digestion peptides for TmTruB showing ${ }^{33}$ VGHGGTLDPFACGVLIIGVNQGTR ${ }^{55}$ (2381.1 monoisotopic mass). A, Reaction and disruption in unlabeled buffer. B, Reaction and disruption in buffer containing $\left[{ }^{18} \mathrm{O}\right]$ water $(50 \%, \mathrm{v} / \mathrm{v})$. C, Reaction and disruption in unlabeled buffer with proteolysis in buffer containing $\left[{ }^{18} \mathrm{O}\right]$ water $(50 \%, \mathrm{v} / \mathrm{v})$. The line diagrams to the right of spectra represent theoretical isotopic intensities. 


\section{$\left[F^{5} U^{*}\right] T m T S L$}

Prior to heat-disrupting the adduct, the ${ }^{18} \mathrm{O}$ content of the reaction was either maintained at $50 \%(\mathrm{v} / \mathrm{v})$ or diluted to achieve $10 \%(\mathrm{v} / \mathrm{v})$ final composition. Following 15 min at $94{ }^{\circ} \mathrm{C}$, the RNA was freed of denatured TmTruB by centrifugation, digested with RNase $\mathrm{T} 1$, dephosphorylated with alkaline phosphatase, and analyzed by mass spectrometry. If the oxygen atom in $\mathrm{F}^{5} \mathrm{U}^{*}$ comes directly from solvent, the extent of ${ }^{18} \mathrm{O}$ incorporation would mirror the isotopic composition of the buffer $(50 \%$ or $10 \%)$.

For the reaction run in labeled buffer, the RNaseT1 digests of both samples (50\% and $10 \%$; Figure 2.20, panel $\mathrm{C}$ and $\mathrm{D}$ ) explicitly show that ${ }^{18} \mathrm{O}$ is incorporated into RNA directly from the solvent. However, these experiments did not clarify the timing of ${ }^{18} \mathrm{O}$ incorporation-whether it is during the formation or the disruption of the adduct. The reaction run in unlabeled buffer and heat-disrupted in buffer containing $\left[{ }^{18} \mathrm{O}\right]$ water $(50 \%)$ (Figure 2.20, panel E) shows that ${ }^{18} \mathrm{O}$ incorporation depends on the composition of the buffer during the disruption step. However, given the 1:4 TmTruB:[F5]TmTSL reaction stoichiometry and based on $50 \%$ adduction as judged by the urea-PAGE analysis of this sample (data not shown), only $1 / 8$ of the total RNA should incorporate ${ }^{18} \mathrm{O}$. In other words, the percentage of ${ }^{18} \mathrm{O}$ incorporation was higher (50\%) than expected (12.5\%).

To make sure the unusual amount of ${ }^{18} \mathrm{O}$ incorporation into RNA was not introduced by an error in the calculation of relative isotopic intensities, the RNase T1 digest of $\left[F^{5} U^{*}\right]$ TmTSL from the labeled reactions $\left(50 \%\right.$ and $\left.10 \%{ }^{18} \mathrm{O}\right)$ was 


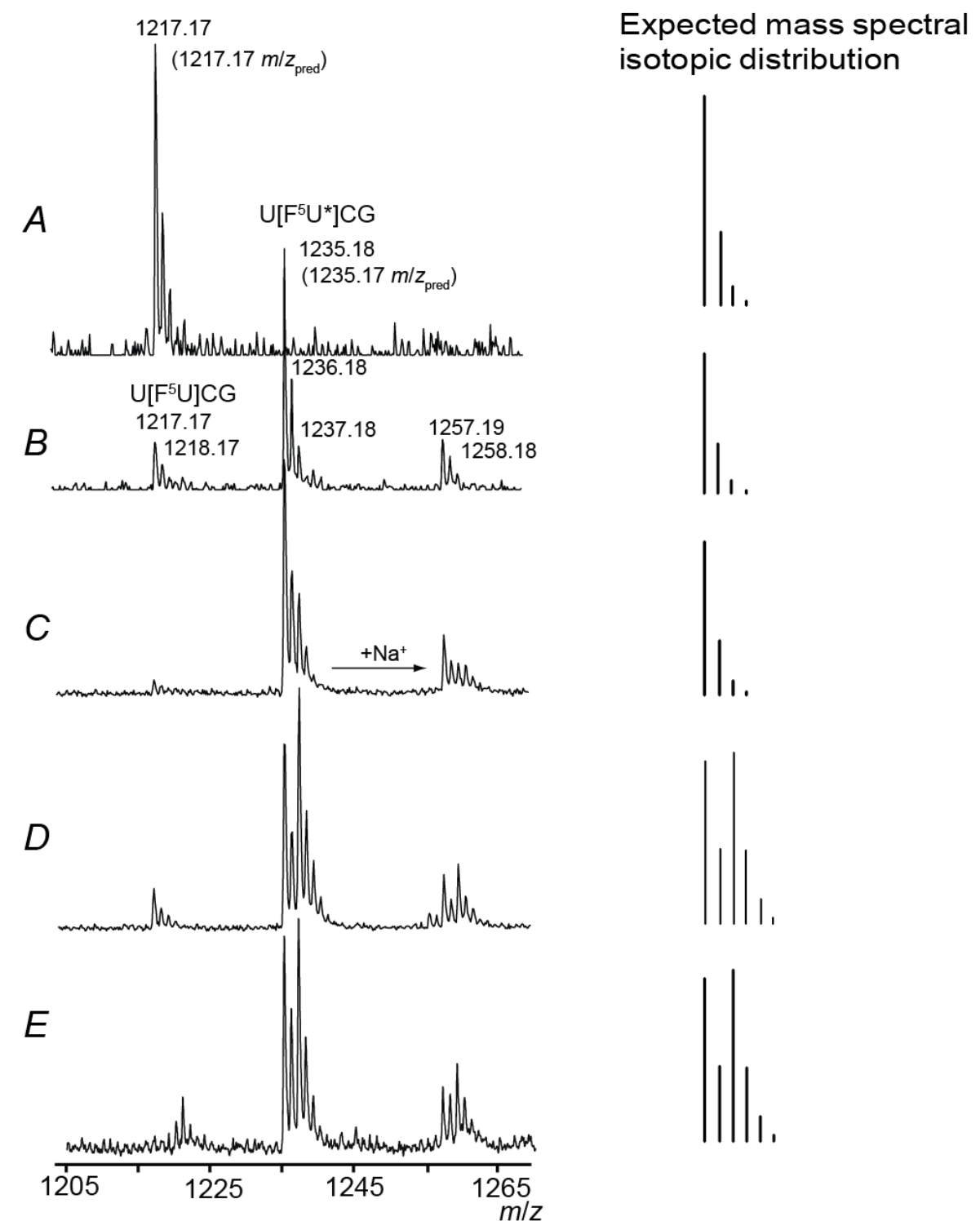

Figure 2.20: Partial mass spectra of the RNase T1-digested [ $\left.\mathrm{F}^{5} \mathrm{U}\right] \mathrm{TmTSL}$ showing the oligonucleotide containing the $F^{5} U$ (U[F5]CG; $1217.17 \mathrm{~m} / \mathrm{z}_{\mathrm{pred}}$ ). $A,\left[F^{5} U\right] T m T S L . B,\left[F^{5} U^{*}\right]$ TmTSL from reaction in unlabeled buffer. $C$, [F5 $\left.\mathrm{U}^{*}\right] \mathrm{TmTSL}$ from reaction in buffer containing $\left[{ }^{18} \mathrm{O}\right]$ water $(50 \%, \mathrm{v} / \mathrm{v})$ followed by dilution to $10 \%{ }^{18} \mathrm{O}$ prior to digestion. $\mathrm{D},\left[\mathrm{F}^{5} \mathrm{U}^{\star}\right] \mathrm{TmTSL}$ from reaction in buffer containing $\left[{ }^{18} \mathrm{O}\right]$ water $(50 \%, \mathrm{v} / \mathrm{v})$ and digested without isotopic dilution. $E,\left[\mathrm{~F}^{5} \mathrm{U}^{*}\right] \mathrm{TmTSL}$ from reaction in unlabeled buffer and disruption in buffer containing $\left[{ }^{18} \mathrm{O}\right]$ water $(50 \%, \mathrm{v} / \mathrm{v})$. 
was purified using reverse phase HPLC, and the fractions bearing $\mathrm{F}^{5} \mathrm{U}^{*}$-containing oligonucleotide were pooled, concentrated, and analyzed. This additional step of purification resulted in mass spectra with greater intensity and better isotopic resolution. However, the calculated isotopic composition of the $\mathrm{F}^{5} \mathrm{U}^{*}$ matched the results prior to the HPLC purification, suggesting that the observed results were not artifactual.

\section{TmTruB can handle $\left[\mathrm{F}^{5} \mathrm{U}^{*}\right] \mathrm{TmTSL}$}

For the adduction reaction run in unlabeled buffer and heat disrupted in standard reaction buffer made with $\left[{ }^{18} \mathrm{O}\right]$ water $(50 \%, \mathrm{v} / \mathrm{v})$, the unexpectedly high incorporation of ${ }^{18} \mathrm{O}$ into $\mathrm{F}^{5} \mathrm{U}^{*}$ (Figure 2.20, panel E), is possible only if TmTruB is able to handle $\left[\mathrm{F}^{5} \mathrm{U}^{*}\right] \mathrm{TmTSL}$ in solution. In other words, not only does TmTruB handle $\left[\mathrm{F}^{5} \mathrm{U}\right] \mathrm{TmTSL}$, but it can also dehydrate and rehydrate $\mathrm{F}^{5} \mathrm{U}^{*}$, thereby altering its isotopic composition to match that of the solvent. For this to happen, TmTruB must be active toward $\left[\mathrm{F}^{5} \mathrm{U}^{*}\right] \mathrm{TmTSL}$ during the initial stages of heating to disrupt the adduct. To test this theory, $\left[\mathrm{F}^{5} \mathrm{U}^{*}\right] \mathrm{TmTSL}$ was incubated in labeled buffer, and TmTruB was added shortly before heat treatment followed by the isolation of RNA, digestion, and analysis. The mass spectrum showed ${ }^{18} \mathrm{O}$ incorporation (50\%) into $\mathrm{F}^{5} \mathrm{U}^{*}$ (Figure 2.21), indicating that TmTruB is able to handle $\left[\mathrm{F}^{5} \mathrm{U}^{*}\right] \mathrm{TmTSL}$. 


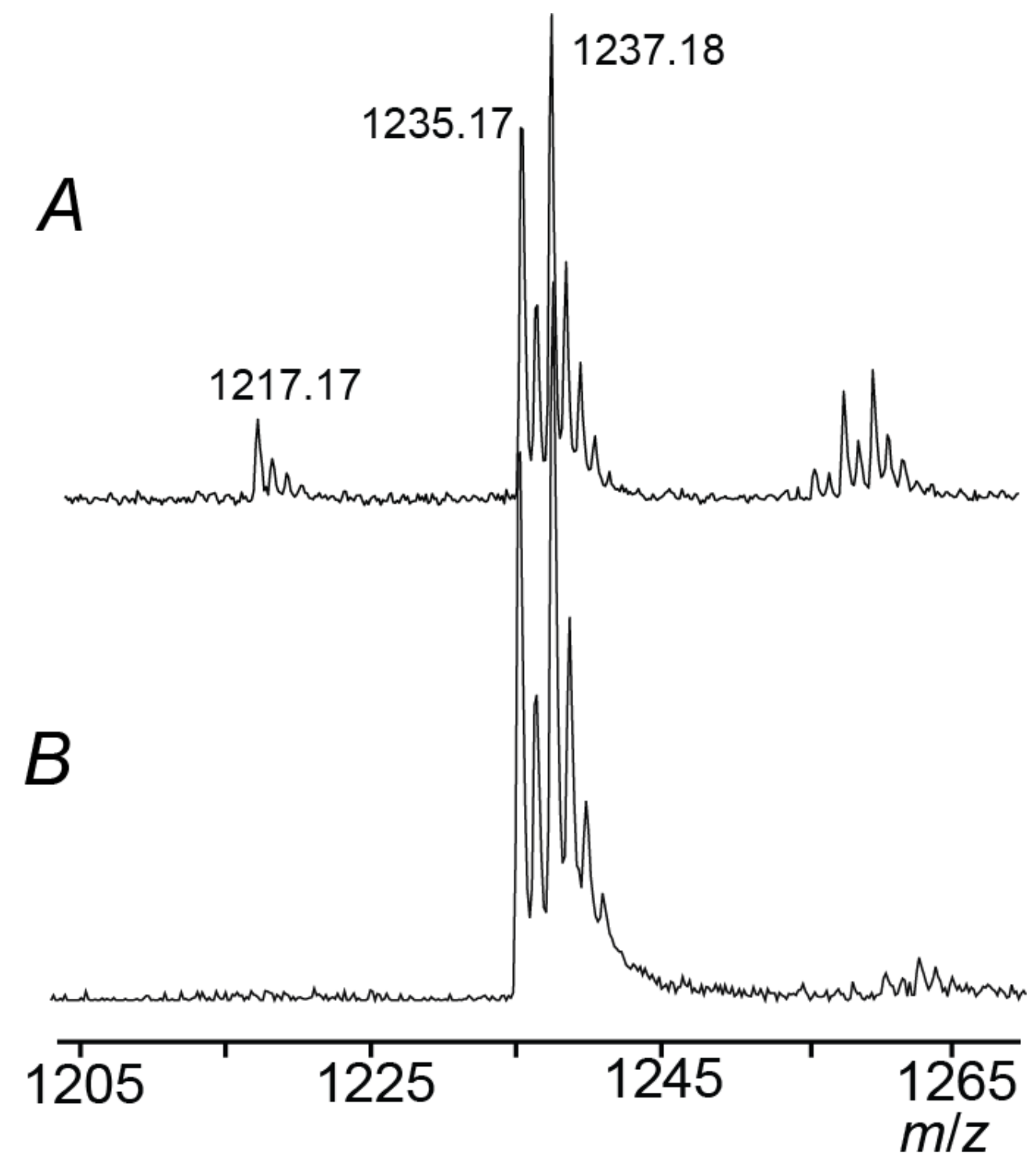

Figure 2.21: Partial mass spectra for the RNase T1 digests of $\left[F^{5} U^{*}\right] T m T S L$. A, Adduction reaction and heat disruption in buffer containing $\left[{ }^{18} \mathrm{O}\right]$ water $(50 \%, v / v) . B$, Pre-formed $\left[F^{5} U^{*}\right] T m T S L$ incubated with TmTruB in buffer containing $\left[{ }^{18} \mathrm{O}\right]$ water $(50 \%, \mathrm{v} / \mathrm{v})$ immediately prior to the heating. 
Table 2.6: Relative isotope intensities for $U\left[F^{5} U^{\star}\right] C G$ under different ${ }^{18} \mathrm{O}$ labeling regimes.

\begin{tabular}{lll}
\hline$m / z$ & theoretical & observed \\
\hline
\end{tabular}

unlabeled reaction and disruption

1235.18

1236.18

1237.18

labeled reaction (50\%) and disruption (50\%)

1235.18

1236.18

1237.18

1238.18

1239.19
88.1

42.3

100

43.1

14.6
100

46.7

17.2

labeled reaction (50\%) and disruption (10\%)

1235.18

1236.18

1237.18

100

46.1

100

27.5

9.41

52.6

1238.18

2.75

42.2

19.2

1239.19

unlabeled reaction and labeled disruption (50\%)

1235.18

1236.18

1237.18

1238.18

91.7

55.2

100

42.4

1239.19

91.7

60.1

100

47.4

22 


\section{Discussion}

\section{Kinetic characterization of TmTruB}

An effective assay was developed for the kinetic characterization of TmTruB. The kinetic parameters, $k_{\mathrm{cat}}=0.67 \pm 0.02 \mathrm{~s}^{-1}$ and $K_{\mathrm{m}}=1112 \pm 58 \mathrm{nM}$ reveal TmTruB at $58{ }^{\circ} \mathrm{C}$ to be a better catalyst than EcTruB and RluA at $37^{\circ} \mathrm{C}$ (Table 2.7). [29, 30, 64] These $k_{\text {cat }}$ and $K_{m}$ values were obtained at a relatively high salt concentration $(250 \mathrm{mM})$. At a salt concentration (125 mM sodium chloride) similar to that used for the assay of EcTruB and RluA (100 mM ammonium chloride), TmTruB had such greater activity that it proved impractical to determine the initial velocities.

\section{Adduct formation between TmTruB and [ $\left.\mathrm{F}^{5} \mathrm{U}\right] \mathrm{TmTSL}$}

The formation of a covalent adduct between TmTruB and [ $\left.\mathrm{F}^{5} \mathrm{U}\right] \mathrm{TmTSL}$ was explored by denaturing PAGE and HPLC analysis. The SDS-PAGE and ureaPAGE gels showed a new band that contained both protein and RNA. Also, TmTruB pre-incubated with [ $\left.\mathrm{F}^{5} \mathrm{U}\right] \mathrm{TmTSL}$ showed a continuing decrease in catalytic activity that suggests TmTruB gets increasingly inhibited upon exposure to [F5]RNA. However, TmTruB could never be completely driven into the adduct as judged by denaturing PAGE (Figure 2.9). This failure to achieve complete adduction raises the question of whether the adduct is noncovalent, although it seems implausible for a noncovalent adduct to survive the denaturing conditions

of SDS and urea-PAGE gels. This behavior of TmTruB (partial adduction) could arise for two reasons. First, TmTruB may need to adopt a specific conformation 
Table 2.7: Kinetic parameters obtained for TmTruB in comparison to those for EcTruB [29, 64] and RluA. [30]

\begin{tabular}{ccc}
\hline Enzyme & $\boldsymbol{k}_{\text {cat }}, \mathbf{s}^{-1}$ & $\boldsymbol{K}_{\mathbf{m}, \mathbf{n M}}$ \\
\hline TmTruB & $0.67 \pm 0.02$ & $1112 \pm 58$ \\
EcTruB & $0.24^{\mathrm{a}}$ & $800^{\mathrm{a}}$ \\
& $0.12 \pm 0.01^{\mathrm{b}}$ & $146 \pm 14^{\mathrm{b}}$ \\
RluA & $0.067 \pm 0.003$ & $308 \pm 66$ \\
\hline
\end{tabular}

aWith TSL [29]

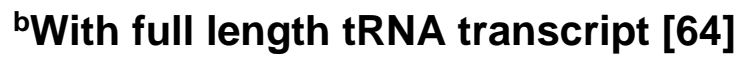


to bind RNA, and only a part of the protein exists in such a conformation at any given time. 2) Part of TmTruB (the free protein seen on gels) may exist as a dimer or some other multimeric form of TmTruB that cannot bind RNA. To assess whether TmTruB exists as a dimer, size exclusion chromatography was used to measure the apparent $M_{\mathrm{r}}$ for TmTruB. These studies surprisingly revealed different estimations of $M_{\mathrm{r}}$ for TmTruB in phosphate buffer $(40.5 \mathrm{kDa})$ and Tris $\bullet \mathrm{HCl}$ buffer (25.0 kDa) compared to the theoretical monomeric value (37.6 kDa; Figure 2.14).

Two alternative hypotheses could account for this observed discrepancy in the molecular weight of TmTruB. The crystal structure (Figure 2.15) shows that the shape of TmTruB is distinctly rod-like rather than spherical, [47] which should lead to greater penetration into the pores of the size exclusion resin and therefore an anomalously low apparent molecular weight. In this scenario, the apparent molecular weight of TmTruB is distinctly underestimated in both buffers, and TmTruB is a monomer in Tris $\bullet \mathrm{HCl}$ buffer but a dimer in phosphate buffer, which could be mimicking the phosphodiester backbone of RNA substrate. TruA, a member of a different family of $\Psi$ synthases, appears to be a dimer in the crystal structure and behaves so in gel filtration in phosphate buffer.[77] In that case, the interaction between the dimers was such to make the oligomer more nearly spherical, but the putative TmTruB dimer would have to be an association of monomers that maintains an elongated shape to explain the data. This hypothesis seems less likely than the following one. The decrease in the apparent molecular weight of TmTruB in Tris versus phosphate buffer arises from a conformational 
change, likely because the phosphate buffer mimics the phosphodiester backbone of RNA.

The crystal structures of TmTruB with and without $\left[\mathrm{F}^{5} \mathrm{U}^{\star}\right] \mathrm{RNA}$ bound (Figure 2.22) show movement of a small domain (indicated by the arrow). In the apo form, the domain is tucked down next to the body of TmTruB but is flipped up and away from the body of TmTruB to interact with RNA. If phosphate induces an approximation of the latter conformation, it would decrease the penetration of TmTruB into the pores of the size exclusion resin and increase the apparent molecular weight (to that expected for a globular protein in order to explain the data). If the change in the apparent $M_{\mathrm{r}}$ of TmTruB in Tris buffer arises from a conformational change and the protein is truly monomeric, a population of TmTruB dimer (or higher oligomer) unable to react with $\left[\mathrm{F}^{5} \mathrm{U}\right] \mathrm{RNA}$ can account neither for the unbound TmTruB observed in SDS-PAGE gels nor the lack of correlation between the stoichiometry of product and adduct formation.

\section{Implications for the turnover of [ $\left.\mathrm{F}^{5} \mathrm{U}\right] \mathrm{TmTSL}$ by TmTruB}

The urea-PAGE analysis of the time course for the formation of $\left[\mathrm{F}^{5} \mathrm{U}^{*}\right] \mathrm{TmTSL}$ shows a slow but continually increasing ratio of adduct to free components over $3 \mathrm{~h}$ (Table 2.3). Also, the HPLC analysis of the time course performed in parallel to the gel analysis revealed that TmTruB achieves multiple turnovers of $\left[F^{5} U\right] R N A$ just like EcTruB does. Similar to the urea-PAGE analysis, activity assays show that TmTruB-unlike EcTruB—gets increasingly inhibited upon exposure to [ $\left.\mathrm{F}^{5} \mathrm{U}\right] \mathrm{RNA}$. While it is unlikely for a noncovalent adduct to survive 

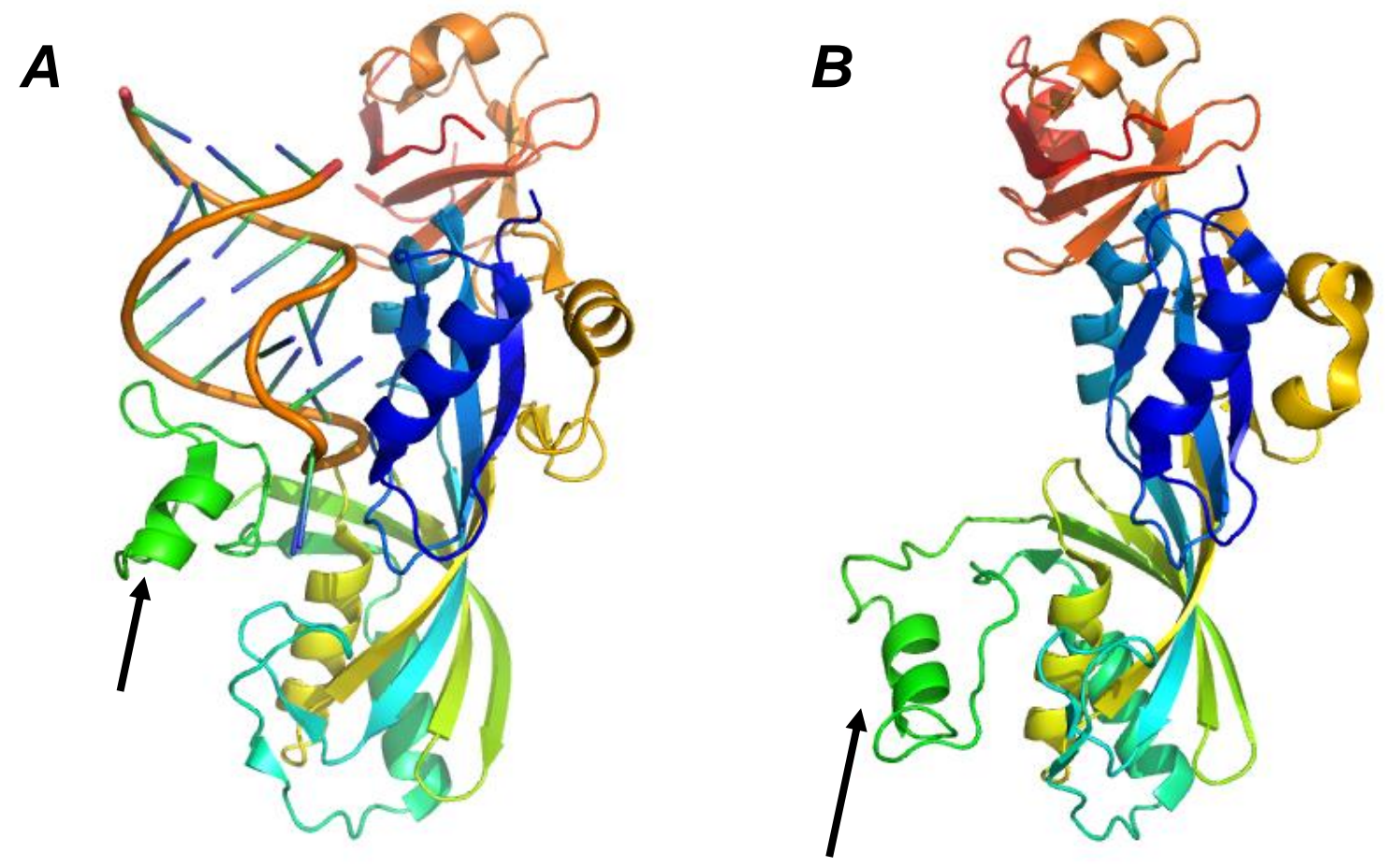

Figure 2.22: Crystal structures of TmTruB. A, Bound with RNA. B, Unbound. Comparison of the two structures shows a conformational change in a small domain (green, indicated by the arrows), which is tucked down in the unbound TruB but flipped away to interact with RNA in the bound form. 
the denaturing conditions of gel electrophoresis, the seemingly contradictory results suggest that the adduct forms reversibly. The observation of the adduct on denaturing PAGE gels and the inhibition of TmTruB suggest that the adduct is covalent. The continuously changing ratio of adduct to free components on denaturing PAGE gels implies reversible adduction.

\section{${ }^{18} \mathrm{O}$ labeling studies}

The ${ }^{18} \mathrm{O}$ labeling studies with TmTruB show the incorporation of label into RNA rather than the conserved Asp. These results conclusively demonstrate that the additional oxygen atom in $\mathrm{F}^{5} \mathrm{U}^{*}$ comes directly from solvent rather than from the conserved Asp through ester hydrolysis, as found previously with EcTruB, RluA, and TruA. [25, 42, 66] Such results strongly disfavor ester hydrolysis as the cause of hydration of $F^{5} \mathrm{U}$ even in case of TmTruB. Unlike the case with the $\Psi$ synthases examined earlier, the ${ }^{18} \mathrm{O}$ content of $\mathrm{F}^{5} \mathrm{U}^{*}$ reflects the isotopic composition of the last water in which TmTruB encountered the RNA. This unique result can arise from the following scenario. TmTruB releases unhydrated but rearranged $F^{5} U$ whether it initially binds $\left[F^{5} U\right] T m T S L$ or $\left[F^{5} U^{*}\right] T m T S L$, and the released species spontaneously hydrates in solution. In other words, TmTruB can both rearrange $F^{5} U$ and dehydrate $F^{5} U^{*}$. This continuous dehydration/rehydration of $\mathrm{F}^{5} \mathrm{U}^{*}$ nicely explains the apparent discrepancy in the percentage of ${ }^{18} \mathrm{O}$ content incorporated into $\mathrm{F}^{5} \mathrm{U}^{*}$. The binding equilibrium between TmTruB and $\left[\mathrm{F}^{5} \mathrm{U}\right] \mathrm{TmTSL}$ or $\left[\mathrm{F}^{5} \mathrm{U}^{*}\right] \mathrm{TmTSL}$ is poised such that substantial amounts of free and bound enzyme are observed in denaturing gels. The existence of such a binding equilibrium is supported by the changing ratios of adduct to free TmTruB seen by urea-PAGE 
with time (Figure 2.15) and in replicates (Figure 2.10), which indicates an exquisite sensitivity to fine variations in the reaction and gel conditions. Bound enzyme is inhibited in activity towards TmTSL $^{\cup}$ (Figure 2.10), but free enzyme is sufficiently abundant to achieve multiple turnovers of $\left[F^{5} \mathrm{U}\right] \mathrm{TmTSL}$ as seen in the HPLC analysis for the formation of $\left[\mathrm{F}^{5} \mathrm{U}^{\star}\right] \mathrm{TmTSL}$ (Figure 2.17). This makes the behavior of TmTruB intermediate between that of EcTruB (no observed adduct; multiple turnovers) and RluA and TruA (stoichiometric adduction; single turnover).

Helm and co-workers [78] recently hypothesized that the TmTruB-[F5]RNA adduct is noncovalent based on spectroscopic studies using RNA decorated with fluorophores at different sites. [78] Those investigators did not observe an adduct between TmTruB and [ $\left.\mathrm{F}^{5} \mathrm{U}\right] \mathrm{RNA}$ on urea-PAGE, which led them to conclude that the adduct is not stable enough to be covalent. [78] However, adduction is clearly shown here by both urea- and SDS-PAGE, although the levels were variable and the maximal level of adduct varied with the gel denaturant. Furthermore, Helm and co-workers used a lower percentage gel (10\% versus $15 \%)$ and full-length tRNA transcript rather than stem-loop, which may contribute to the apparent discrepancy. The ability of the TmTruB-[ $\left.\mathrm{F}^{5} \mathrm{U}\right] \mathrm{TmTSL}$ adduct to withstand the denaturing gel conditions supports the covalency of the adduct, even though a covalent bond was not visualized in the crystal structure of TmTruB with [ $\left.F^{5} U\right] R N A$. [47] When Helm and co-workers observed a fast-forming band on SDS-PAGE gels, they reasonably concluded that such rapid formation of a covalent complex is precluded for an enzyme as slow as TruB. [78] Their conclusion was based on the kinetics of EcTruB, but TmTruB is a more efficient catalyst than its mesophilic 
homolog (Table 2.7), so rapid formation of the TmTruB-[F5 $U$ ]TmTSL adduct is not surprising. Also, Helm and co-workers initially assumed that TmTruB suicidally forms a covalent intermediate, but the collective results reported here imply that TmTruB and [ $\left.\mathrm{F}^{5} \mathrm{U}\right] \mathrm{RNA}$ form a covalent adduct but do so reversibly.

\section{The (still) consistent scheme for handling of $F^{5} U$}

Recently, Stroud and co-workers reported a cocrystal structure for RluB and $\left[\mathrm{F}^{5} \mathrm{U}\right] \mathrm{RNA}$ in which a covalent adduct was found between the hydroxyl group of Tyr-146 and the pyrimidine ring of $\mathrm{F}^{5} \mathrm{U}$ (Chapter 1, [46]). Their results led them to the conclusions similar to the consistent scheme proposed by the Mueller group for the handling of $\mathrm{F}^{5} \mathrm{U}$ by $\Psi$ synthases (Figure 2.23). The data reported here for TmTruB nicely fits the scheme. By any mechanism, TmTruB rearranges $F^{5} U$ to the C-glycoside. By virtue of the electrophilic $\mathrm{C6}$, the rearranged $\mathrm{F}^{5} \mathrm{U}$ either gets trapped by an active site nucleophile (Tyr-146 in RluB; putatively the conserved Asp in RluA, TruA, and TmTruB), or gets released into solution and undergoes spontaneous hydration. After releasing $\left[\mathrm{F}^{5} \mathrm{U}^{*}\right] \mathrm{TmTSL}$, TmTruB either binds $\left[\mathrm{F}^{5} \mathrm{U}\right] \mathrm{TmTSL}$ or rebinds $\left[\mathrm{F}^{5} \mathrm{U}^{*}\right] \mathrm{TmTSL}$ for dehydration/rehydration. All data is consistent with the entrapment of the rearranged $\mathrm{F}^{5} \mathrm{U}$. 


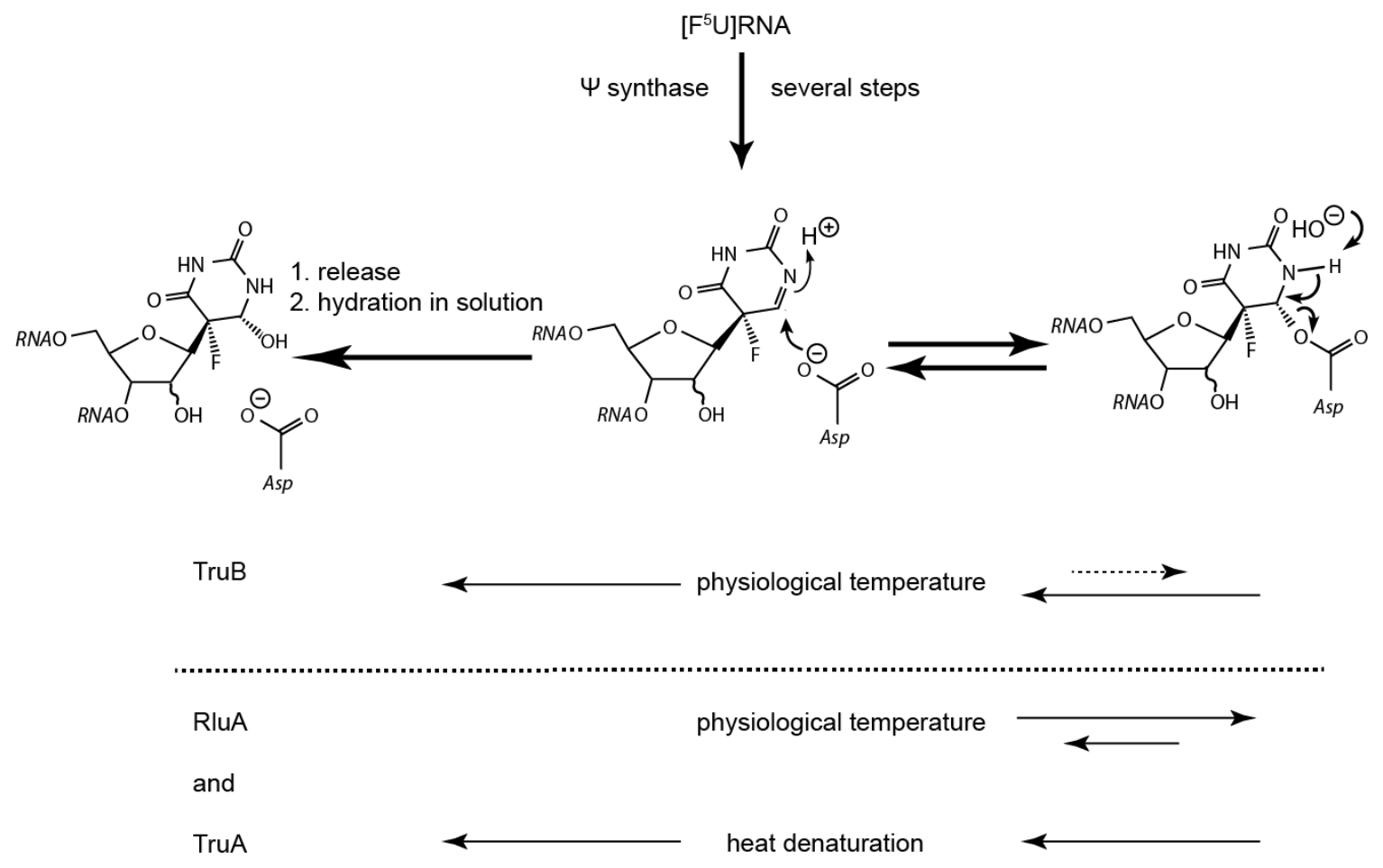

Figure 2.23: The slightly revised scheme of Mueller and co-workers that still accounts for all the observed results. 


\section{CHAPTER 3}

\section{DEUTERIUM WASH-IN STUDIES TO PROBE THE GLYCAL MECHANISM}

Pseudouridine synthases ( $\Psi$ synthases) rearrange 5-fluorouridine in RNA to its $C$-glycoside isomer just as they rearrange uridine to pseudouridine $(\Psi)$. The behavior of different $\Psi$ synthases differ towards [ $\left.\mathrm{F}^{5} \mathrm{U}\right] \mathrm{RNA}$. TruA and RluA get irreversibly inhibited in handling [ $\left.\mathrm{F}^{5} \mathrm{U}\right] \mathrm{RNA}$ and form an adduct that appears covalent by denaturing PAGE analysis. $[29,30,36]$ E. coli TruB (EcTruB), on the other hand, is not inhibited by $\left[F^{5} U\right] T S L^{4}$ but instead converts $F^{5} U$ into two rearranged, hydrated products (hereafter, the major and minor products).[25] $T$. maritima TruB (TmTruB) shows an intermediate behavior. TmTruB is only partially adducted at any given time, and enough free enzyme remains to perform multiple turnovers to generate the same major and minor products delivered by the action of EcTruB (Chapter 2).

${ }^{4}$ E. coli TruB was previously shown to handle I-arm stem loop tRNA ${ }^{\text {Phe }}$ (TSL) as an excellent substrate with comparable kinetics to those for the full length tRNA ${ }^{\text {Phe }}$ substrate. [29] 
Initially, two different mechanisms were proposed for the $\Psi$ synthases. In the Michael mechanism, the conserved Asp attacks C6 of the pyrimidine ring of $\mathrm{F}^{5} \mathrm{U}$ to form a covalent Michael adduct (Figure 1.4), and rearrangement to the C-glycoside isomer and deprotonation of C5 complete the reaction. [36] In the acylal mechanism, the conserved Asp instead attacks $\mathrm{C} 1$ ' of the ribose ring to form an acylal intermediate (Figure 1.6); the detached uracilate anion then undergoes a net $180^{\circ}$ rotation to reposition itself for $C$-glycoside formation to generate $\Psi$. [36]

Miracco and Mueller showed that the major product was the rearranged, hydrated species seen in the cocrystal structure of TruB with $\left[F^{5} U\right] R N A$ (Figure 3.1), [40] but the minor product was an arabino isomer of the major product, differing from it in the configuration at C2' of the pentose ring (Figure 3.1). [43] The minor product therefore requires epimerization at $\mathrm{C2}^{\prime}$, so the mechanism must proceed through a glycal intermediate that is reprotonated on the opposite face to yield the observed arabino product. [43] With [ $\left.F^{5} U\right] R N A$, the observed arabino product can be explained as part of the acylal mechanism. The increased acidity of 5-fluorouracil translates into reduced nucleophilicity for its anion relative to the uracilate anion, so the lifetime is lengthened for both the acylal intermediate and the oxocarbenium ion with which it is in equilibrium. [43] The increased acidity of C2' in the latter species makes it easier for the free-and therefore availableconserved Asp to deprotonate C2' from the "top" to form a glycal intermediate (Figure 3.2). Reprotonation from the "bottom" yields the arabino product of $\mathrm{F}^{5} \mathrm{U}$.

The cocrystal structures of several $\Psi$ synthases with [ $\left.F^{5} U\right] R N A$ reveal the conserved Asp to be the only acid/base group positioned in the vicinity of C2' and 


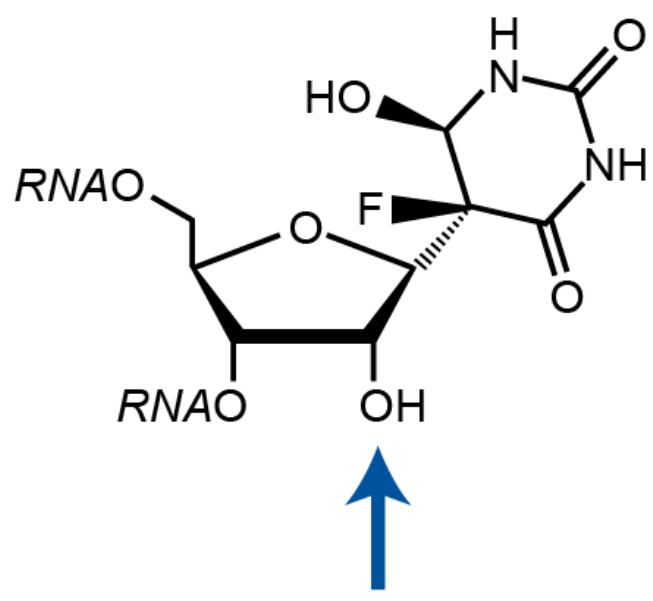

major product: ribo

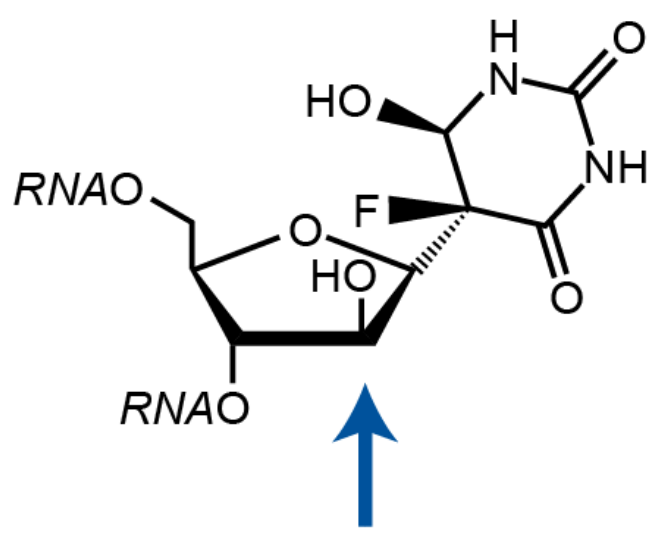

minor product: arabino

Figure 3.1: The identity of the major and minor products of $\mathrm{F}^{5} \mathrm{U}$ differ at the stereo configuration of C2'. [43] 


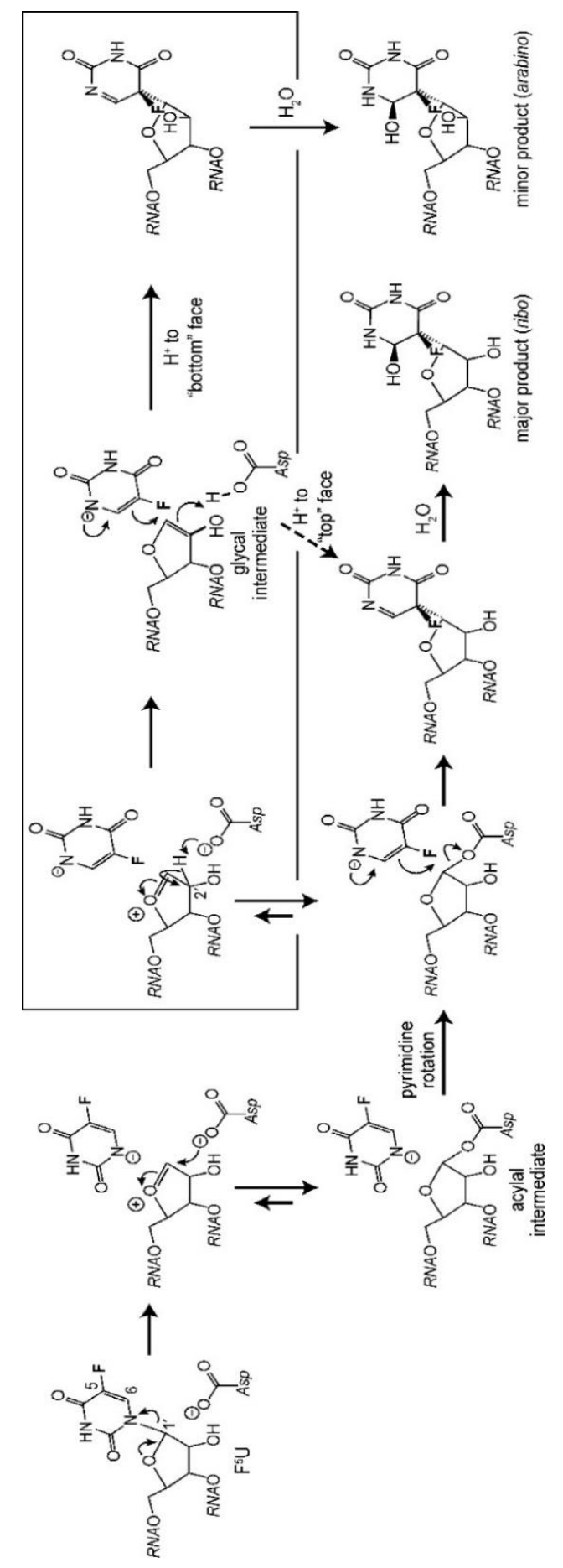

Figure 3.2: The acylal mechanism recast to emphasize features that can account for the arabino product of $\mathrm{F}^{5} \mathrm{U}$. The boxed manifold exists only for $F^{5} \mathrm{U}$ because of the increased life time of the oxocarbenium ion that is in equilibrium with the acylal intermediate. [43] 
so able to deliver a proton to the "bottom" face. Because the Michael mechanism has the conserved Asp tied up in an ester bond at this point, it cannot ferry a proton to the "bottom" face of the glycal to effect reprotonation. Therefore, the arabino product of $\mathrm{F}^{5} \mathrm{U}$ strongly disfavors the Michael mechanism.

If a glycal intermediate forms during the conversion of $U$ to $\Psi$ as it does during the reaction of $\mathrm{F}^{5} \mathrm{U}$, an alternative mechanism arises: the 'glycal' mechanism (Figure 3.3), which can readily account for both the major and minor products of $\mathrm{F}^{5} \mathrm{U}$ (Figure 3.4). Uridine phosphorylase offers an enzymatic precedent for a glycal intermediate in the reaction of nucleotides. [44]. The deprotonation of C2' to form the glycal intermediate can be achieved by either the conserved Asp or the $\mathrm{O}^{2}$ on the pyrimidine ring. [44] Following the $C$-glycoside rearrangement, reprotonation of the pentose ring at $\mathrm{C}^{\prime}$ generates $\Psi$ (Figure 3.3).

\section{Deuterium wash-in}

If the reaction of $\left[F^{5} U\right] R N A$ with $\Psi$ synthases proceeds through a glycal intermediate with the conserved Asp acting as a base to deprotonate C2', the removed proton resides temporarily on the Asp, where it may be prone to exchange with the solvent protons (Figure 3.5) $[79,80]$. If this is true, an observed deuterium "wash-in" would provide evidence for a glycal intermediate along the reaction pathway.

When TruB and RluA were incubated with $\mathrm{U}$ - and $\mathrm{F}^{5} \mathrm{U}$-containing RNA, the mass spectra for the reactions run in unlabeled $\left(\mathrm{H}_{2} \mathrm{O}\right)$ and labeled buffer $\left(\mathrm{D}_{2} \mathrm{O}\right)$ were identical, indicating a lack of deuterium wash-in (Figure 3.6). [81] However, 


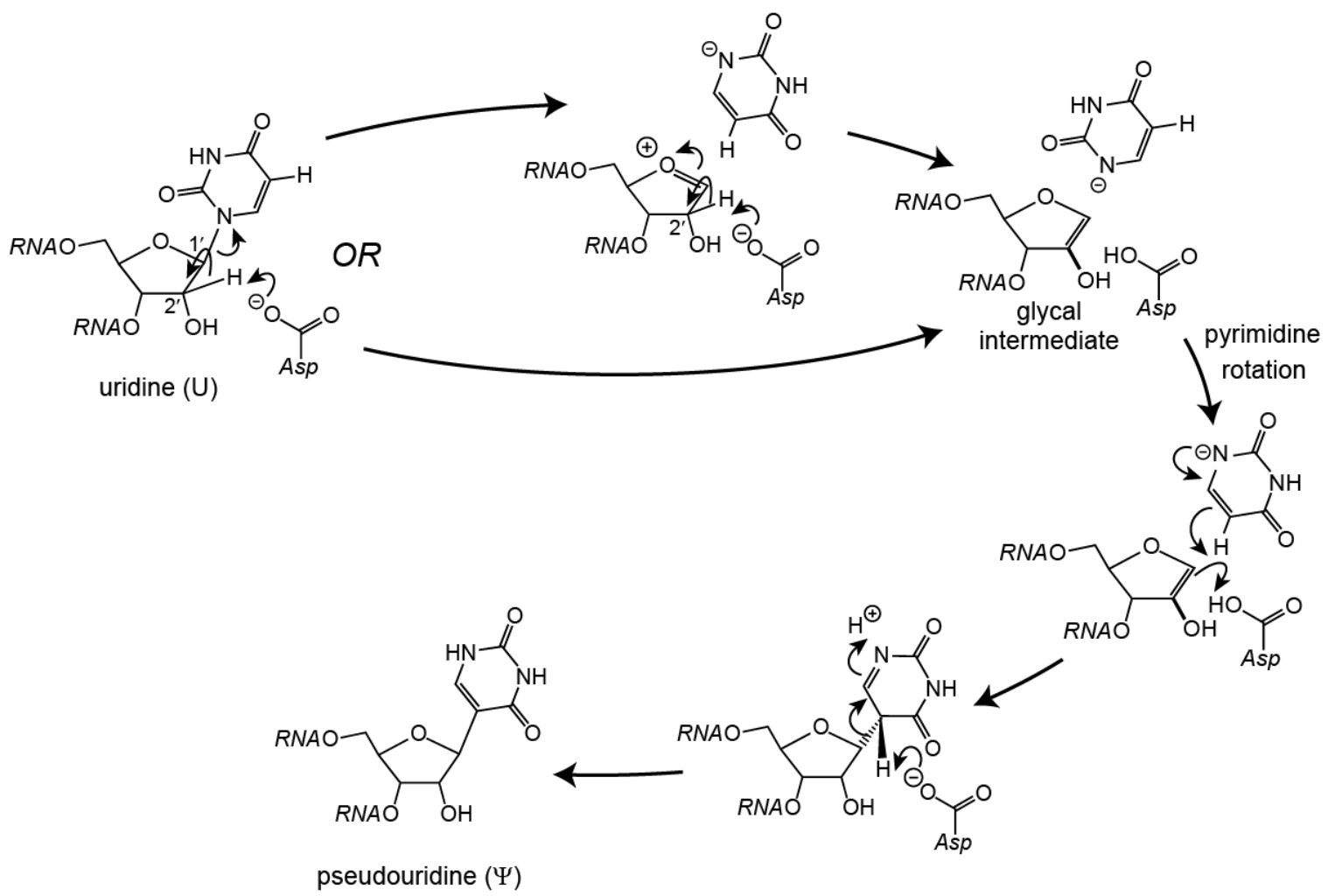

Figure 3.3: The proposed 'glycal mechanism' for $\Psi$ formation. The conserved Asp initiates the reaction by deprotonating C2' that leads to a glycal intermediate. After the C-glycoside rearrangement, $\mathrm{C2}^{\prime}$ is reprotonated by the conserved Asp. 


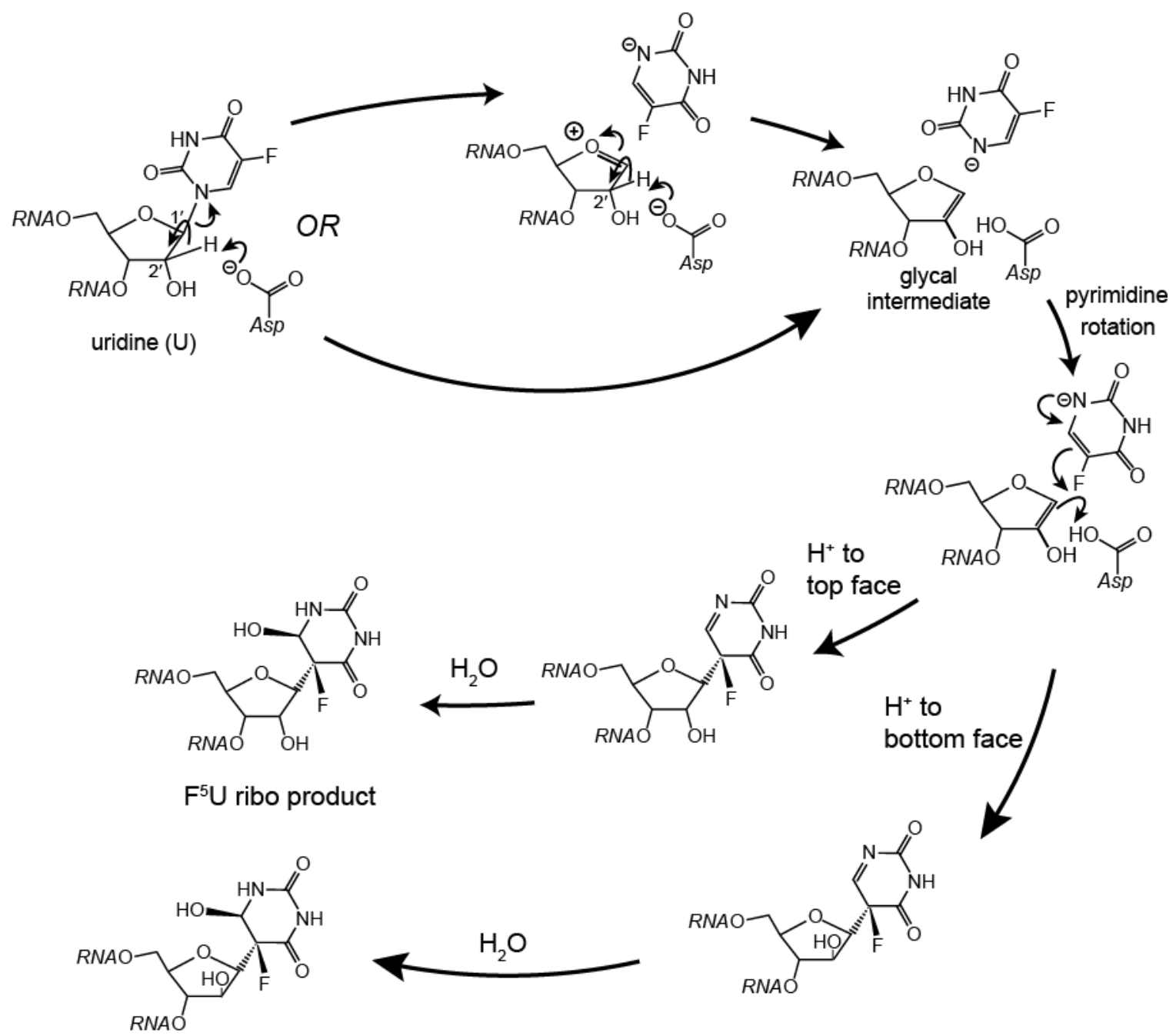

$\mathrm{F}^{5} \mathrm{U}$ arabino product

Figure 3.4: The 'glycal' mechanism with [ $\left.F^{5} \mathrm{U}\right] \mathrm{RNA}$. Reprotonation from the bottom face of the C2' would result in the observed arabino product of $F^{5} \mathbf{S}$. 


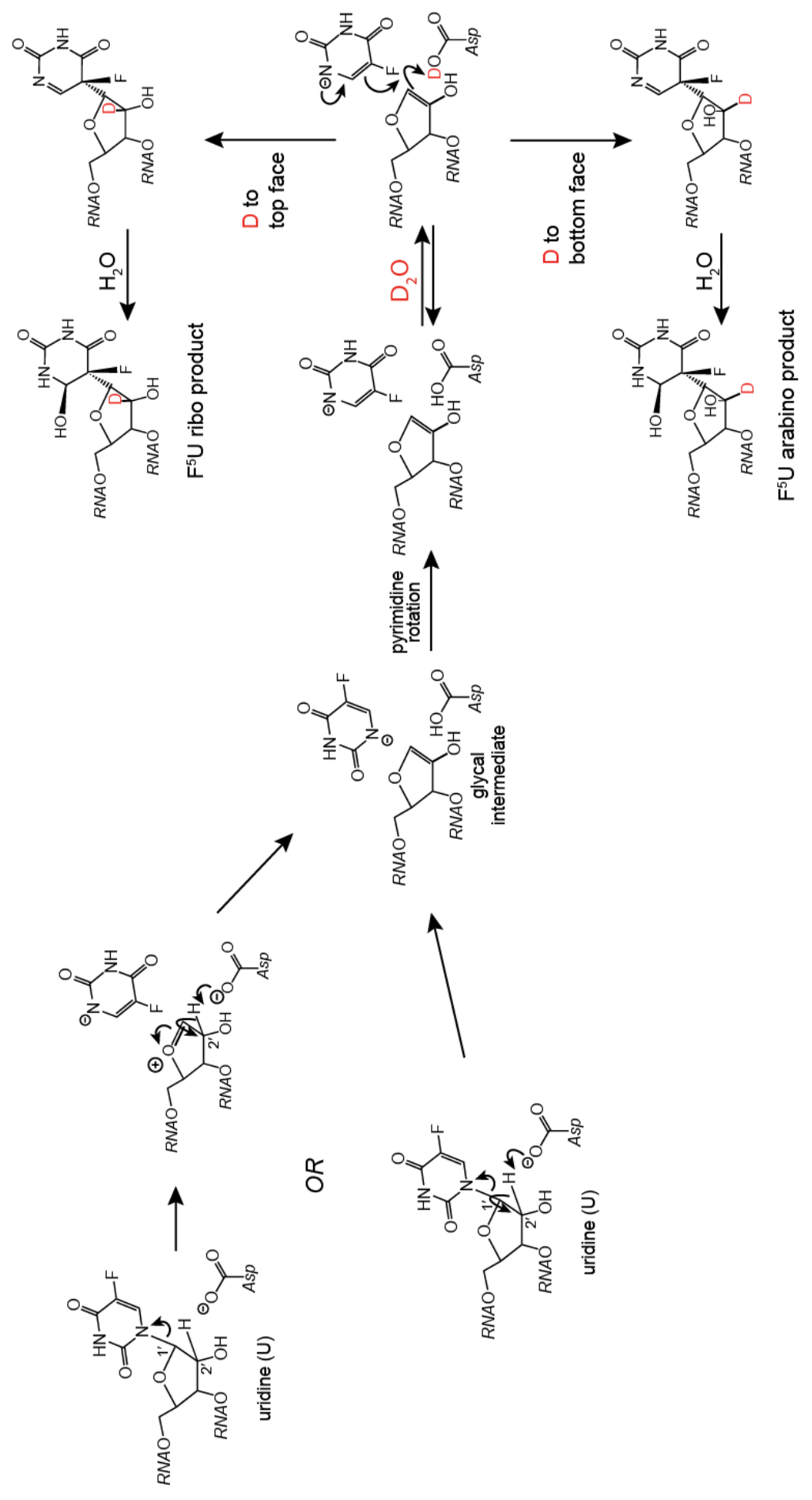

Figure 3.5: Deuterium wash-in scheme for the glycal mechanism with $\mathrm{F}^{5} \mathrm{U}$. If the proton on the conserved Asp can exchange with solvent on the time scale of the conversion of $F^{5} \mathrm{U}$ to its products, deuterium wash-in should be observed in both products of $F^{5} U$. 

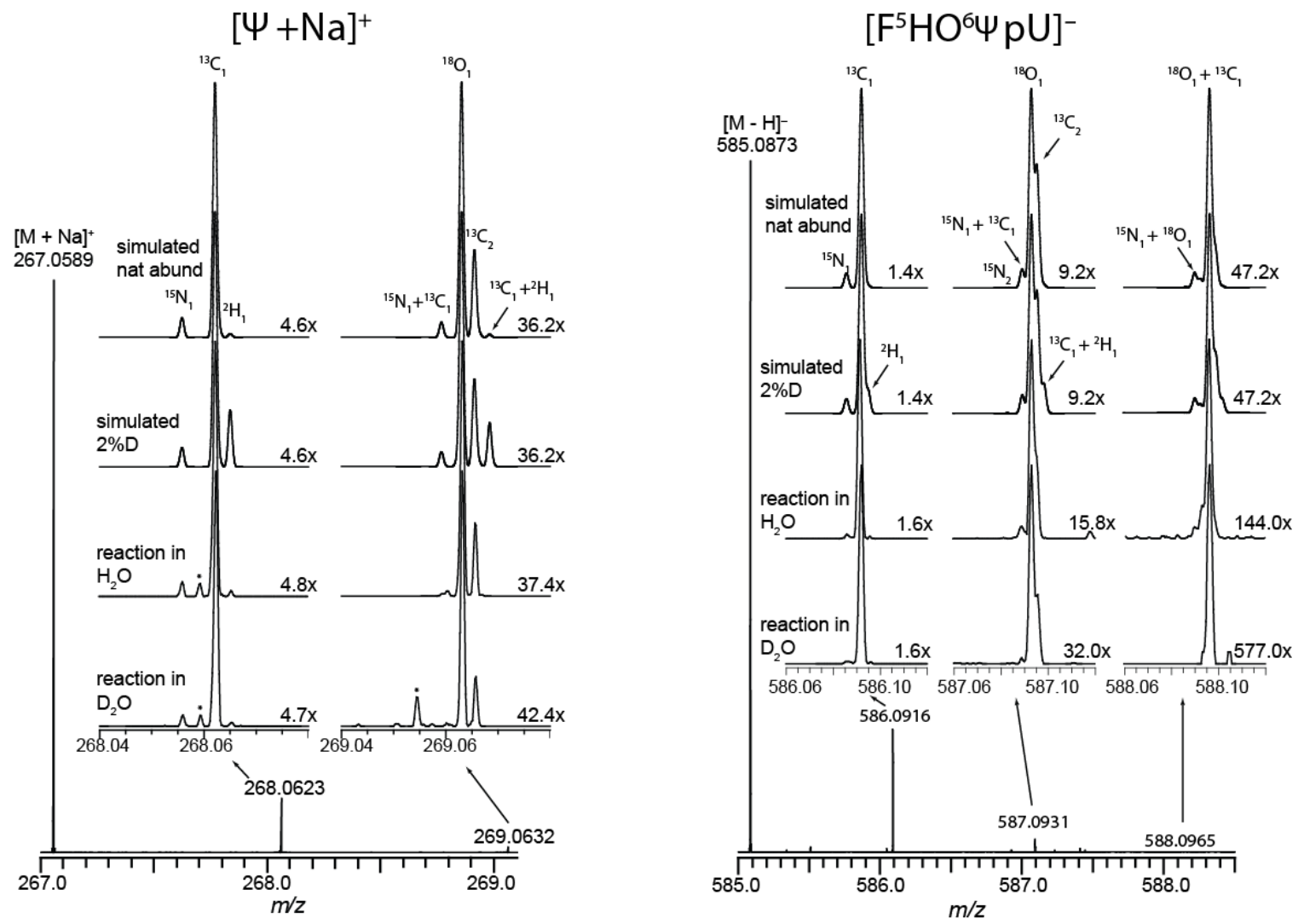

Figure 3.6: Mass spectra for the deuterium wash-in studies on RluA with RNAs containing $U$ (left) and $F^{5} U$ (right). [10] In neither case was deuterium wash-in observed. 
the lack of wash-in remains consistent with a glycal intermediate because the conserved Asp may be occluded from the solvent on the timescale of the conversion of $\mathrm{U}$ to $\Psi$ or $\mathrm{F}^{5} \mathrm{U}$ to $\mathrm{F}^{5} \mathrm{U}^{*}$. A careful literature review revealed that $\mathrm{Y} 76 \mathrm{~L}$ TruB offers an opportunity to probe this matter further.

\section{Y76L TruB}

The $\Psi$ synthases show a conserved aromatic amino acid residue, which is a tyrosine in five of the six families and a phenylalanine in the TruD family. Phannachet et al mutated this tyrosine residue in E. coli TruB. The Y76F, Y76L, and $\mathrm{Y} 76 \mathrm{~A}$ variants lost the natural activity towards $\mathrm{U}$, but $\mathrm{Y} 76 \mathrm{~F}$ and $\mathrm{Y} 76 \mathrm{~L}$ TruB still handle $\mathrm{F}^{5} \mathrm{U}$. [51] Although $\mathrm{Y} 76 \mathrm{~F}$ TruB generates both the major and minor products of $F^{5} \mathrm{U}$, the $\mathrm{Y} 76 \mathrm{~L}$ TruB interestingly produces only the major product and does so slowly (Figure 3.7).[51] Phannachet et al. did not to pursue this unusual behavior further, but it makes Y76L TruB ripe for deuterium wash-in studies for two reasons. First, if the lack of deuterium wash-in observed with wild-type TruB and RluA was due to the exclusion of solvent from the active site, the alteration in the geometry of the active site caused by the $\mathrm{Y} 76 \mathrm{~L}$ mutation might provide a path for solvent molecules to enter the active site, thereby resulting in deuterium wash-in. Second, the slower catalysis supported by $\mathrm{Y} 76 \mathrm{~L}$ TruB with $\left[\mathrm{F}^{5} \mathrm{U}\right] \mathrm{TSL}$ will provide more time for the solvent to access the active site, perhaps enough to allow exchange of the proton that temporarily resides on the conserved Asp. 


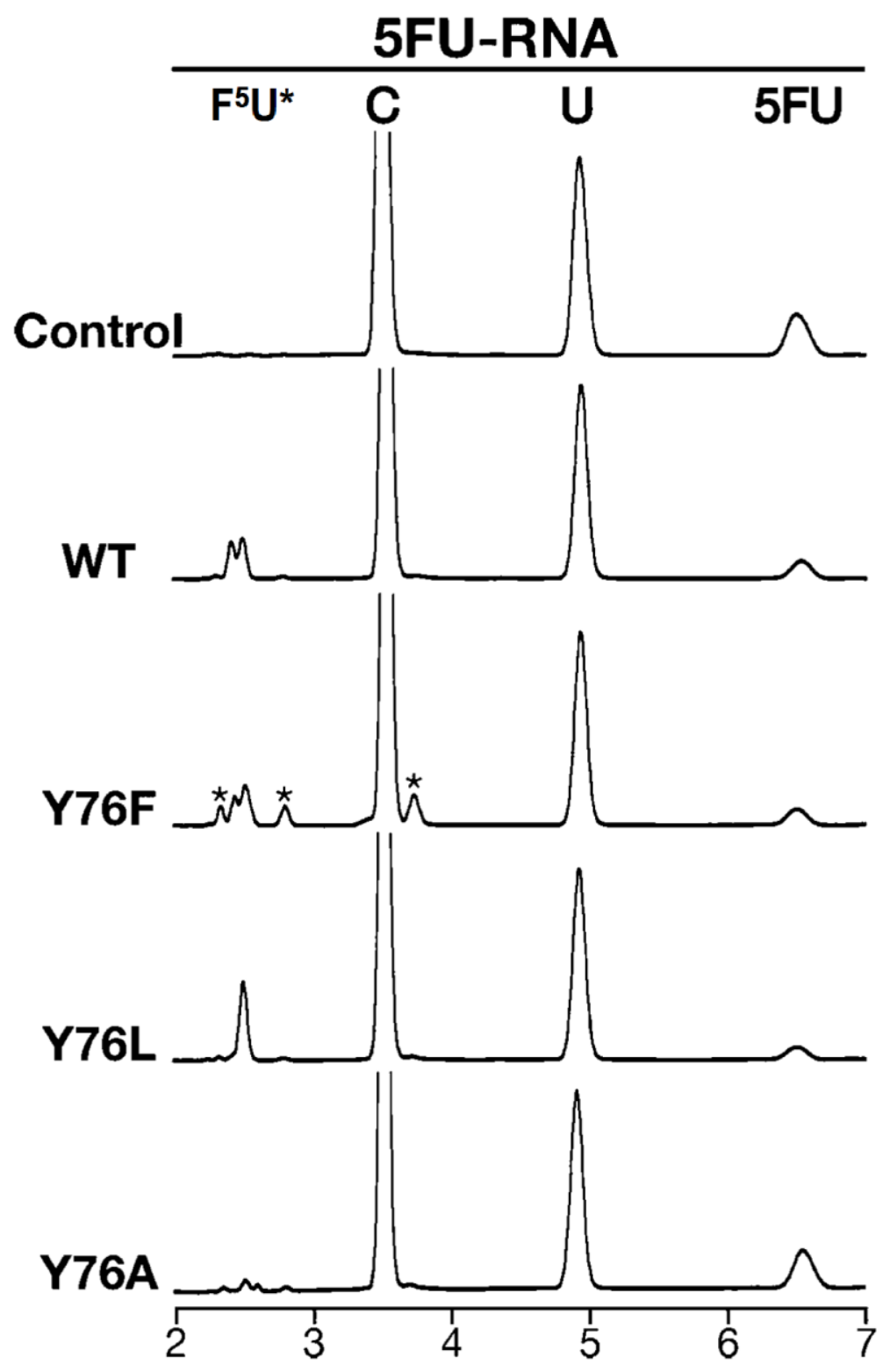

Figure 3.7: HPLC analysis of reaction products of 5FU-RNA incubated with E. coli $\Psi 55 S$ wild-type or Y76 mutants by Phannachet et al. [11] Each stemloop RNA was incubated with the indicated TruB variants, and the product RNA was enzymatically digested to nucleosides and analyzed by reverse phase HPLC. * indicates impurity peaks. From reference 51. 


\section{Experimental section}

\section{General}

Modified chymotrypsin (sequencing grade) was purchased from Roche (Indianapolis, IN). Immobilized pepsin was purchased from Fisher Scientific (Waltham, MA). RNA oligonucleotides were obtained from GE Dharmacon (Layafette, CO), deprotected according to the manufacturer's protocol, and purified as described in Chapter 2. Deuterium oxide (99.9\%) was obtained from Cambridge Isotope Laboratories, Inc. (Tewksbury, MA). Y76L TruB was generated in silico and energy-minimized using the GROMOS 43B1 force field [82] as implemented in Swiss-Pdb Viewer v4.0. [83] PyMOL v1.3 was used to generate high-resolution graphics of these structures. [84]

\section{Subcloning, overexpression, and purification of Y76L TruB}

The plasmid encoding Y76L TruB (pUL323) was created by introducing a point mutation into truB (from E. coli) in p $\Psi 55$ using the Stratagene QuickChange ${ }^{\mathrm{TM}}$ site-directed mutagenesis kit using the manufacturer's protocols with the following primers: 5'-GACTCCGACAAAGGTCTCCGGGTCATTGCG-3' (forward), and 5'CTGTCCAAGACGCGCAATGACCCGG-3' (reverse); the sequence of the insert in pUL323 was verified by DNA sequencing. BLR(DE3) pLysS cells were transformed with pUL323 for the overexpression of Y76L TruB. Overexpressed Y76L TruB was purified over Ni-NTA resin (Qiagen) using the same protocol used for wild-type TruB. [64] Subsequently, Y76L TruB was polished over a POROS HQ anion exchange column (PE Biosystems) attached to a BioCAD SPRINT FPLC run by Perfusion Chromatography Workstation v3.01. Elution was achieved by 
application of a gradient of potassium chloride $(0.1-1.4 \mathrm{M})$ in $50 \mathrm{mM}$ Tris $\bullet \mathrm{HCl}$ buffer, $\mathrm{pH} 7.9$; the enzyme generally eluted at $325-450 \mathrm{mM}$ salt. Fractions bearing Y76L TruB were tested for RNase contamination, and the RNase-free fractions were pooled, concentrated, and stored at $-20^{\circ} \mathrm{C}$ in 50 mM HEPES buffer, $\mathrm{pH} 7.5$, containing ammonium chloride (100 mM), EDTA (1 mM), and glycerol $(10 \%, v / v)$.

\section{Digestion and MALDI-MS analysis of Y76L TruB}

\section{Pepsin digestion}

Y76L TruB $(50-100 \mu \mathrm{g})$ was incubated for $5 \mathrm{~min}$ at $94{ }^{\circ} \mathrm{C}$ to denature the protein, which was pelleted by centrifugation $(18,000 \mathrm{~g}, 5 \mathrm{~min})$. A slurry $(120 \mu \mathrm{L})$ of immobilized pepsin in aqueous trifluoroacetic acid $(0.1 \%, \mathrm{v} / \mathrm{v}), \mathrm{pH} 2.5$, was then added to the pelleted protein. After incubation for $12 \mathrm{~h}$ at $37^{\circ} \mathrm{C}$, an aliquot $(10 \mu \mathrm{l})$ of the digest was loaded on to a ZipTip ${ }_{\mathrm{c} 18}$ pipetter tip (Millipore, Bedford, MA); the bound peptides were washed $(10 \times 10 \mu \mathrm{l})$ with aqueous trifluoroacetic acid (TFA) $(0.1 \%, v / v)$ and eluted with matrix solution $(5 \mu l)$, which was 4-chloro- $\alpha$ cyanocinnamic acid $(6.24 \mathrm{mg} / \mathrm{ml})$ in $70 \%$ aqueous acetonitrile containing TFA $(0.1 \%, v / v)$. The ZipTip eluate $(1 \mu l)$ was spotted on a MALDI sample plate and air dried. Mass spectra were acquired using a Voyager DE-Pro MALDI-TOF instrument (PE Biosystems, Foster City, $\mathrm{CA}$ ) with acquisition in positive reflectron mode with an extraction delay time of 200 ns and 400 laser shots per spectrum. Calibration was achieved using a 1:1:2 mixture of Bradykinin fragment 1-7 (757.399 monoisotopic mass), fragment 18-39 of ACTH (2465.1989), and the oxidized $\beta$-chain of insulin (3494.6513). 


\section{Chymotrypsin digestion}

Y76L TruB $(50 \mu \mathrm{g})$ was heat-denatured and pelleted as described above. The pellet was suspended in $100 \mathrm{mM}$ Tris buffer, $\mathrm{pH} 7.8$, containing calcium chloride $(10 \mathrm{mM})$, to which chymotrypsin $(2 \mu \mathrm{g})$ was added followed by incubation for $12 \mathrm{~h}$ at $37^{\circ} \mathrm{C}$. An aliquot $(10 \mu \mathrm{L})$ of the digestion mixture was desalted using ZipTip $_{\mathrm{C} 18}$, and mass spectra were acquired as described above for the pepsin digestion.

\section{Analysis of $\mathrm{Y76L}$ TruB and [ $\left.\mathrm{F}^{5} \mathrm{U}\right] \mathrm{TSL}$ reaction}

Y76L TruB $(10 \mu \mathrm{M})$ was incubated at $37^{\circ} \mathrm{C}$ with $\left[\mathrm{F}^{5} \mathrm{U}\right] \mathrm{TSL}(50 \mu \mathrm{M})$ in $50 \mathrm{mM}$ HEPES buffer, pH 7.5, containing ammonium chloride (100 mM), EDTA (1 mM), and DTT $(5 \mathrm{mM})$ (hereafter, standard reaction buffer). Aliquots $(30 \mu \mathrm{L})$ were withdrawn at $3 \mathrm{~h}$ and $6 \mathrm{~h}$ and quenched by mixing with $2 x$ Laemmli buffer $(30 \mu \mathrm{L})$. Following this, the sample was either heated for 5 min at $94{ }^{\circ} \mathrm{C}$ or loaded directly onto the gel $(0.1 \% \mathrm{v} / \mathrm{v}, 10 \%, 10 \times 10 \mathrm{~cm})$, which was run $(165 \mathrm{~V}, 80-90 \mathrm{~min})$ and stained with Coomassie ${ }^{\text {TM }}$ Blue to visualize protein bands.

For HPLC analysis of the RNA, an aliquot $(10 \mu \mathrm{L})$ of the reaction mixture was diluted into $\mathrm{S} 1$ nuclease digestion buffer $(90 \mu \mathrm{L})$, which is $30 \mathrm{mM}$ sodium acetate buffer, $\mathrm{pH} 4.6$, containing sodium chloride $(50 \mathrm{mM})$, zinc chloride $(10 \mathrm{mM})$, and glycerol $(5 \%, \mathrm{v} / \mathrm{v})$. S1 nuclease $(0.5 \mu \mathrm{L}, 50 \mathrm{U})$ was added, and the mixture was incubated for $1 \mathrm{~h}$ at $37^{\circ} \mathrm{C}$ and then at $94^{\circ} \mathrm{C}$ for 5 min followed by cooling on ice for 5 min. Subsequently, a fresh aliquot of $S 1$ nuclease $(1 \mu \mathrm{L}, 100 \mathrm{U})$ and alkaline phosphatase ( $3 \mu \mathrm{L}, 3 \mathrm{U})$ were added, and the mixture was incubated for $3 \mathrm{~h}$ at 
$37^{\circ} \mathrm{C}$. The digestion mixture was then analyzed over an SB-C 18 analytical column connected to Beckman Coulter System Gold HPLC (Indianapolis, IN) equipped with a Model 168 programmable diode array detector module.

\section{Inhibition of Y76L TruB by $\left[F^{5} U^{\star}\right] T S L$}

Y76L TruB $(10 \mu \mathrm{M})$ was either pre-incubated with $\left[\mathrm{F}^{5} \mathrm{U}^{*}\right] \mathrm{TSL}(20 \mu \mathrm{M})$ for 15 min at $37^{\circ} \mathrm{C}$ or was allowed to react directly with $\left[\mathrm{F}^{5} \mathrm{U}\right] \mathrm{TSL}(50 \mu \mathrm{M})$ in standard reaction buffer $(60 \mu \mathrm{L})$ at $37^{\circ} \mathrm{C}$. Aliquots $(10 \mu \mathrm{L})$ of the reaction mixture were withdrawn at various times $(0-240 \mathrm{~min})$ and were immediately quenched by incubation in boiling water for $5 \mathrm{~min}$ followed by cooling on ice for $5 \mathrm{~min}$. The aliquot was then diluted into $S 1$ nuclease digestion buffer $(90 \mu \mathrm{L})$, digested with $\mathrm{S} 1$ nuclease, dephosphorylated with alkaline phosphatase, and analyzed by reverse phase HPLC as described above.

\section{Deuterium wash-in}

Deuterated standard reaction buffer was prepared by repeated lyophilization $(3 x)$ of the standard reaction buffer to dryness and redissolution in $\mathrm{D}_{2} \mathrm{O}(>99 \%)$. All exchangeable protons in $\left[\mathrm{F}^{5} \mathrm{U}\right] \mathrm{TSL}$ were replaced with deuterium by three cycles of dissolution and lyophilization with deuterated buffer. [ $\left.F^{5} U\right] T S L$ $(50 \mu \mathrm{M})$ in deuterated standard reaction buffer $(146.5 \mu \mathrm{L})$ was incubated for $5 \mathrm{~min}$ at $37^{\circ} \mathrm{C}$ before the reaction was started by the addition of $\mathrm{Y} 76 \mathrm{~L}$ TruB $(10 \mu \mathrm{M}, 3.5$ $\mu \mathrm{l})$, which resulted in a final deuterium content of $96.6 \%$. After $4 \mathrm{~h}$ at $37^{\circ} \mathrm{C}$, the reaction was heated to $94{ }^{\circ} \mathrm{C}$ for $5 \mathrm{~min}$, cooled on ice for $5 \mathrm{~min}$, centrifuged $(18,000 \mathrm{~g}, 5 \mathrm{~min})$ and spun to pellet the protein, which was discarded. Residual 
protein was extracted from the supernatant with 1:1 phenol:chloroform, and the RNA was precipitated with ethanol and air-dried. The RNA was redissolved in S1 nuclease digestion buffer $(100 \mu \mathrm{L})$, and digested to nucleosides by the combination of $\mathrm{S} 1$ nuclease $(2 \times 5 \mu \mathrm{L}$ with heat denaturation in between, $500 \mathrm{U})$ and alkaline phosphatase $(5 \mu \mathrm{L}, 5 \mathrm{U})$. After the complete digestion was confirmed by analytical HPLC, $\mathrm{F}^{5} \mathrm{U}^{*}$ was isolated by preparative reverse phase HPLC over an ultrasphere $\cdot \mathrm{C}_{18}$ column $(5 \mu \mathrm{M}, 10 \times 250 \mathrm{~mm}$; Beckman-Coulter, Fullerton, $\mathrm{CA})$, eluting with a gradient of acetonitrile in water using the method described elsewhere [85] but with a flow rate of $3 \mathrm{~mL} / \mathrm{min}$; under these conditions, $\mathrm{F}^{5} \mathrm{U}^{*}$ eluted at 4-4.5 min. The fractions containing $\mathrm{F}^{5} \mathrm{U}^{*}$ were combined and concentrated to dryness in vacuo, and a part of the residue was dissolved in water $(15 \mu \mathrm{L})$ and then diluted with a 1:1 (v/v) mixture of methanol and formic acid $(135 \mu \mathrm{L})$. The $\mathrm{F}^{5} \mathrm{U}^{*}$ was then analyzed by high resolution mass spectrometry in negative mode on a Thermo Finnigan (Bremen, Germany) Linear trap quadrupole Fourier transform (LTQ-FT) mass spectrometer equipped with a Triversa Nanomate (Ithaca, NY) direct infusion nano - electrospray ion (nESI) source. An unlabeled control reaction was run by incubating TruB $(10 \mu \mathrm{M})$ with $\left[\mathrm{F}^{5} \mathrm{U}\right] \mathrm{TSL}(50 \mu \mathrm{M})$ in standard reaction buffer $(150 \mu \mathrm{L})$ followed by analysis as described above. Data was analyzed using Xcalibur $^{\mathrm{TM}}$ v. 2.0 (Thermo Electron; Waltham, MA). For the labeled reaction (96.66\%, $\mathrm{D}_{2} \mathrm{O}$, the isotopic contributions from each element $\left({ }^{2} \mathrm{H},{ }^{13} \mathrm{C},{ }^{15} \mathrm{~N},{ }^{18} \mathrm{O}\right.$ etc. $)$ in $M+1$ and $M+2$ peaks were calculated relative to the intensity of the monoisotopic peak, which was set to a value of $100 \%$. The difference between the relative intensity value thus obtained for ${ }^{2} \mathrm{H}$ and the relative intensity of the monoisotopic 
peak from the unlabeled reaction was then adjusted by the isotopic composition of the labeled buffer $\left(96.66 \%, \mathrm{D}_{2} \mathrm{O}\right)$ to obtain the percentage of deuterium wash-in. Spectral simulations for a set percentage of deuterium incorporation were obtained using the embedded 'isotope simulation' tool in $\mathrm{Xcalibur}^{\mathrm{TM}}$ v. 2.0. This was achieved by manually defining the mole fractions of protium and deuterium in the chemical formula for the dinucleotide product of $\mathrm{F}^{5} \mathrm{U}$. 


\section{Results}

\section{In silico analysis}

An overlap of the cocrystal structure of wild-type TruB and [F5U]RNA [40] with that of in silico Y76L TruB $[83,84]$ showed a comparatively spacious active site for the variant, primarily due to the lack of steric hindrance associated with the phenyl ring of Tyr-76 (Figure 3.8 and 3.9). The energy-minimized structure for Y76L TruB shows the side chain of Leu-76 positioned perpendicular to the pyrimidine ring of $\mathrm{F}^{5} \mathrm{U}$, in contrast to the more nearly parallel orientation of the Tyr76 phenyl ring in wild-type TruB (Figure 3.8). The effect of the Y76L mutation on the positioning of $\mathrm{F}^{5} \mathrm{U}$ in the active site could not be fully determined because of software limitations that allow energy minimization for the enzyme itself but not bound molecules, including the RNA substrate. $[12,13]$ The space-filling views of the active sites for $\mathrm{Y} 76 \mathrm{~L}$ and wild-type TruB (Figure 3.9) were compared to see if the conserved Asp may now have access to exchange freely with bulk solvent. Even though the RNA remained rigidly fixed, the active site definitely appears more accessible to solvent.

\section{Subcloning, overexpression and purification of Y76L TruB}

To introduce the $\mathrm{Y} 76 \mathrm{~L}$ point mutation to N-terminally His ${ }^{\bullet}$ tagged TruB, pUL323 was created from its parent plasmid $\mathrm{p} \Psi 55$. Overexpressed Y76L TruB was purified to near homogeneity by nickel affinity chromatography followed by anion exchange chromatography. Subsequent storage of $\mathrm{Y} 76 \mathrm{~L}$ TruB under conditions similar to those used for wild-type TruB [64] resulted in $>50 \%$ loss of 

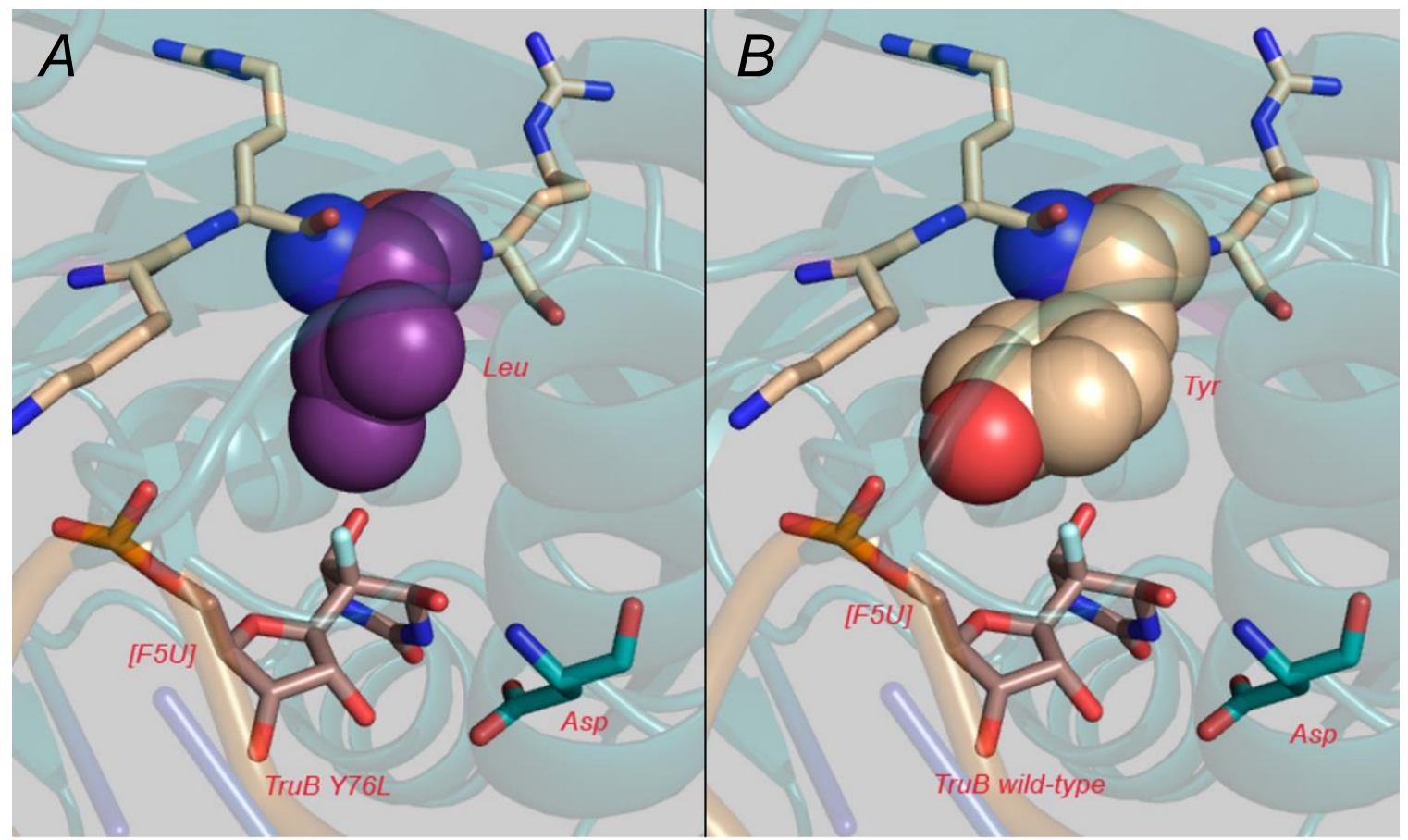

Figure 3.8: An in silico comparison of the active sites of TruB variants. A, Y76L TruB. B, wild-type TruB. The energy-minimized structure for Y76L TruB shows different positioning of Leu-76 and Tyr-76 with respect to $F^{5} U$. [51] 
$A$

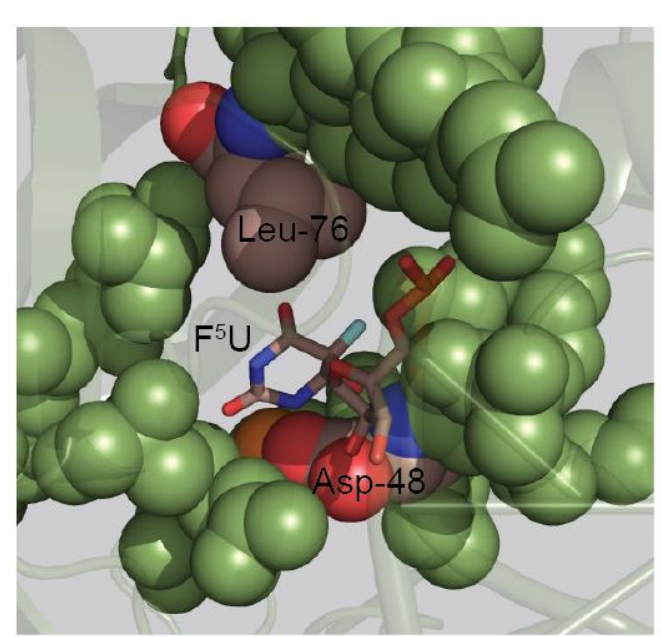

$B$

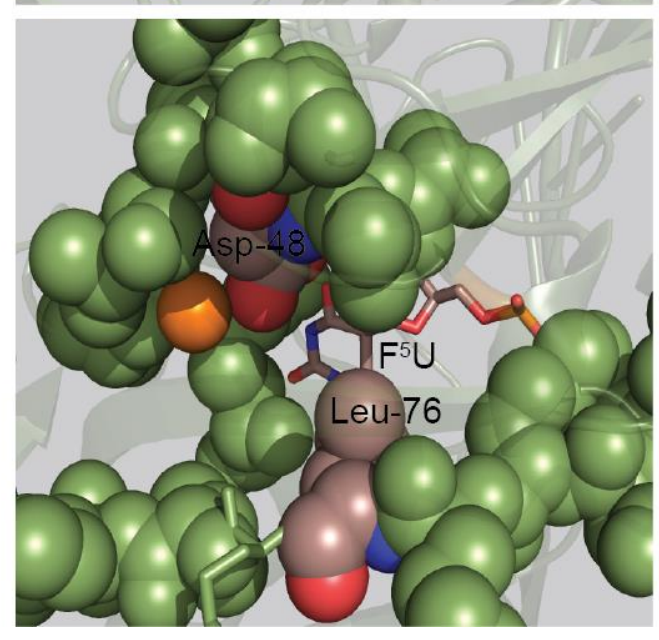

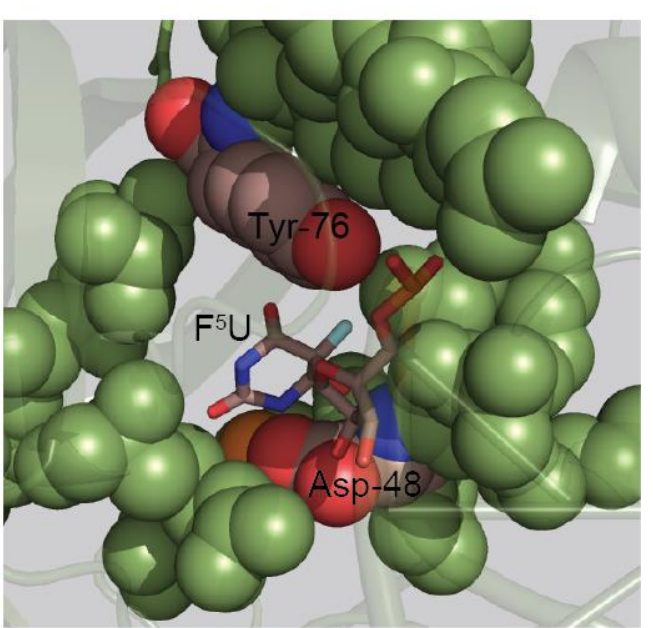

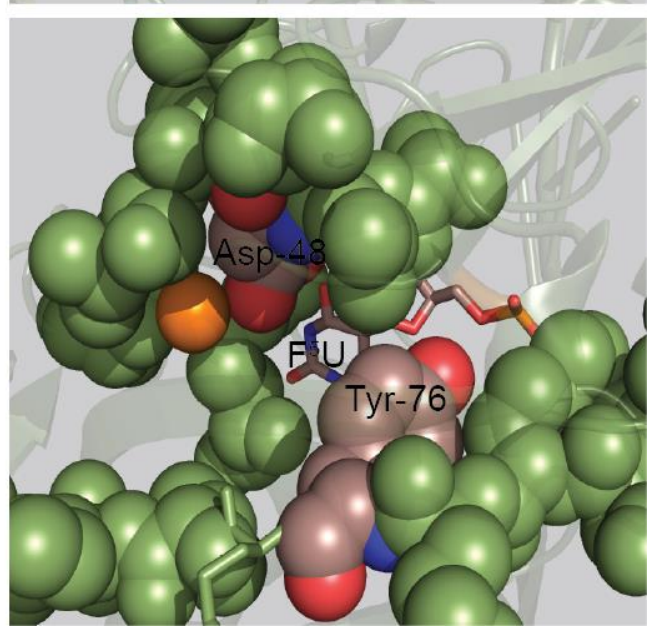

Figure 3.9: Space-filling view of the active site of TruB variants. A, Y76L TruB. B, Y76L TruB. Active site amino acids other than the conserved Asp48 and Tyr/Leu-76 are in green. The lower view is rotated $180^{\circ}$ relative to the upper view. Extra space is introduced around the pyrimidine ring of $\mathrm{F}^{5} \mathrm{U}$ as a result of the mutation. 


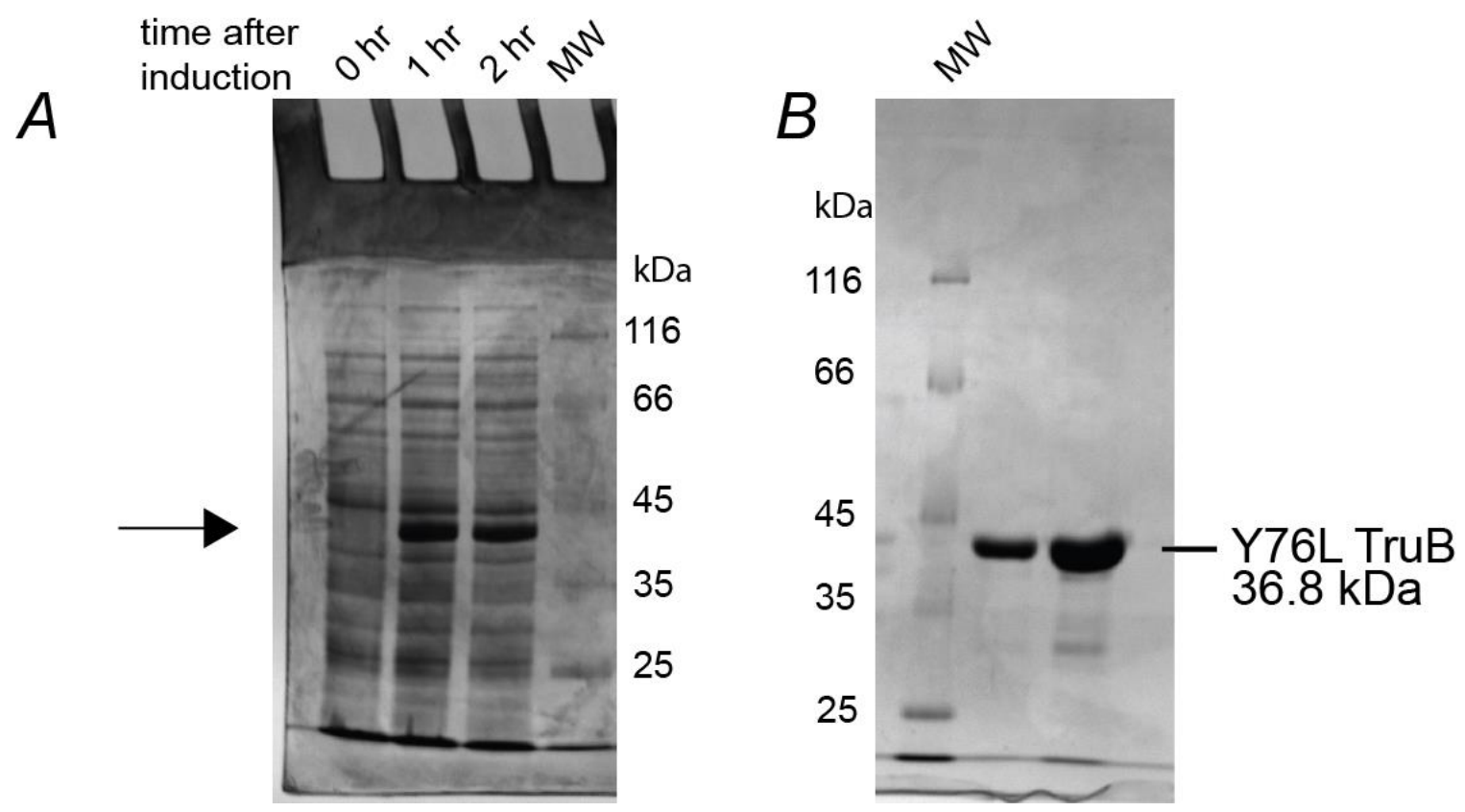

Figure 3.10: SDS-PAGE analysis of the overexpression and purification of Y76L TruB. A, Overexpression of Y76L TruB. B, Fractions of purified Y76L TruB. MW, EZ-Run ${ }^{\mathrm{TM}}$ protein markers (Fisher Scientific; Waltham, MA). 
activity within one week. This instability was successfully addressed by storage at $-20^{\circ} \mathrm{C}$ in in $50 \mathrm{mM}$ HEPES buffer, $\mathrm{pH} 7.5$, containing ammonium chloride (100 $\mathrm{mM})$, EDTA $(1 \mathrm{mM})$, and glycerol $(10 \%, \mathrm{v} / \mathrm{v})$. Under these conditions, the stability of Y76L TruB improved, with $<15 \%$ loss of activity after one month.

\section{MALDI-MS of Y76L TruB}

The sequence of Y76L TruB was verified by MALDI-TOF MS analysis after digestion with chymotrypsin (Figure 3.11 ) or pepsin (data not shown). When compared to the digest of wild-type TruB, the expected shift of $50 \mathrm{~m} / \mathrm{z}$ was observed for the variant peptide containing Leu in place of Tyr-76.

\section{Reaction of Y76L TruB with [F5]TSL}

\section{Identity of the $\mathrm{F}^{5} \mathrm{U}$ product of the $\mathrm{Y} 76 \mathrm{~L}$}

Y76L TruB $(10 \mu \mathrm{M})$ was incubated with [ $\left.\mathrm{F}^{5} \mathrm{U}\right] \mathrm{TSL}(10 \mu \mathrm{M})$ in standard reaction buffer for $3 \mathrm{~h}$ at $37^{\circ} \mathrm{C}$. The RNA sample from this reaction was digested to individual nucleosides and analyzed by reverse phase HPLC. A peak was observed with identical retention time to the major (ribo) product of $\mathrm{F}^{5} \mathrm{U}$ from the action of wild-type TruB (Figure 3.12). A co-injection of the S1 nuclease-digested RNA resulting from the action of wild-type and $\mathrm{Y} 76 \mathrm{~L}$ TruB on $\left[\mathrm{F}^{5} \mathrm{U}\right] \mathrm{TSL}$ confirmed this assignment (Figure 3.12). 


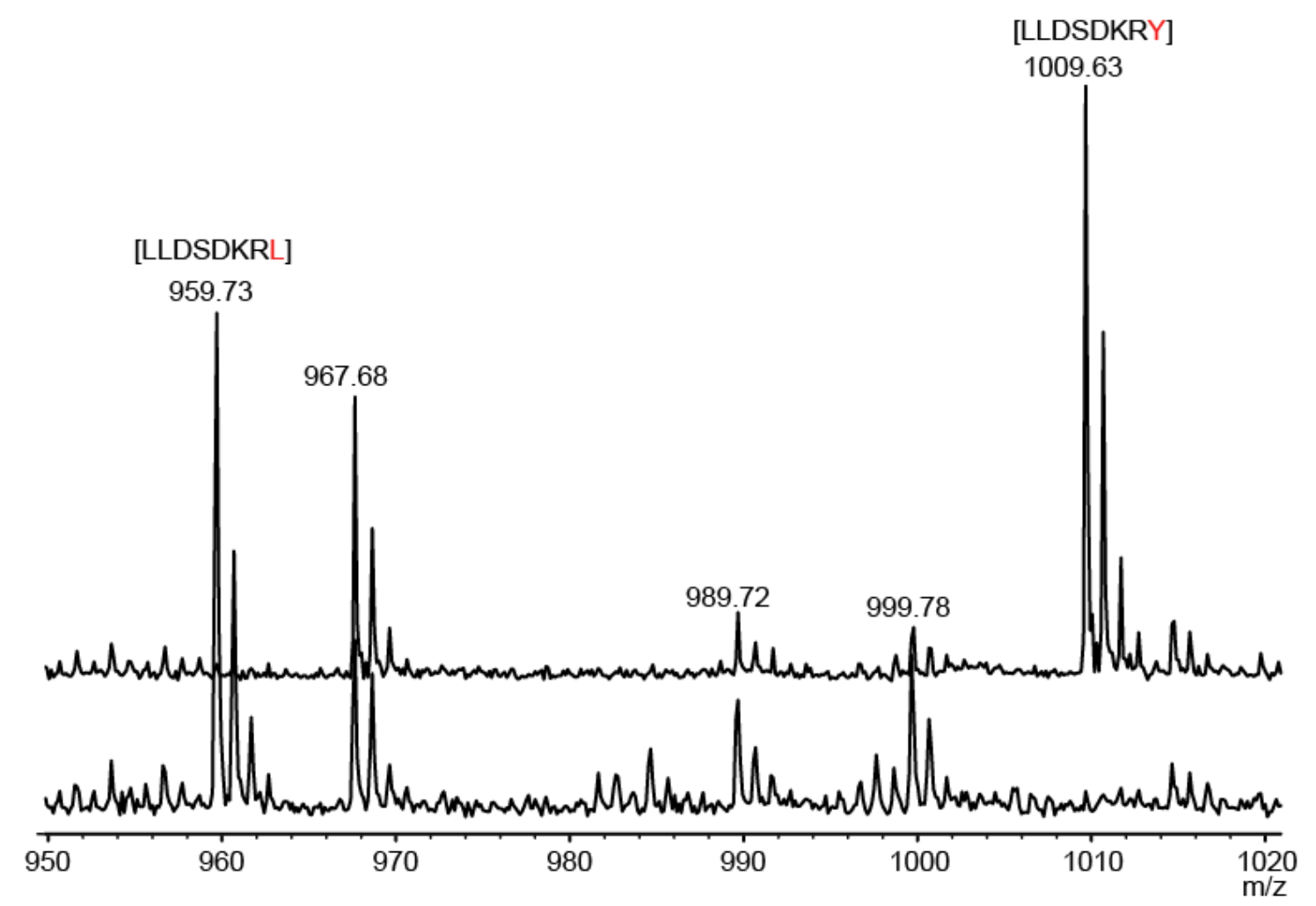

Figure 3.11: Partial mass spectra of the peptides from the chymotryptic digestion of $\mathrm{Y76L}$ (lower) and wild-type TruB (upper). A change in mass is observed for the peptide ${ }^{69}$ LLDSDKRX76 from wild-type TruB $(X=T y$, $\left.1009.52 \mathrm{~m} / \mathrm{z}_{\text {pred}}\right)$ versus $\mathrm{Y76L}$ TruB (X = Leu, $959.54 \mathrm{~m} / \mathrm{z}_{\text {pred; }}$ results from non-canonical cleavage after Leu by chymotrypsin). 


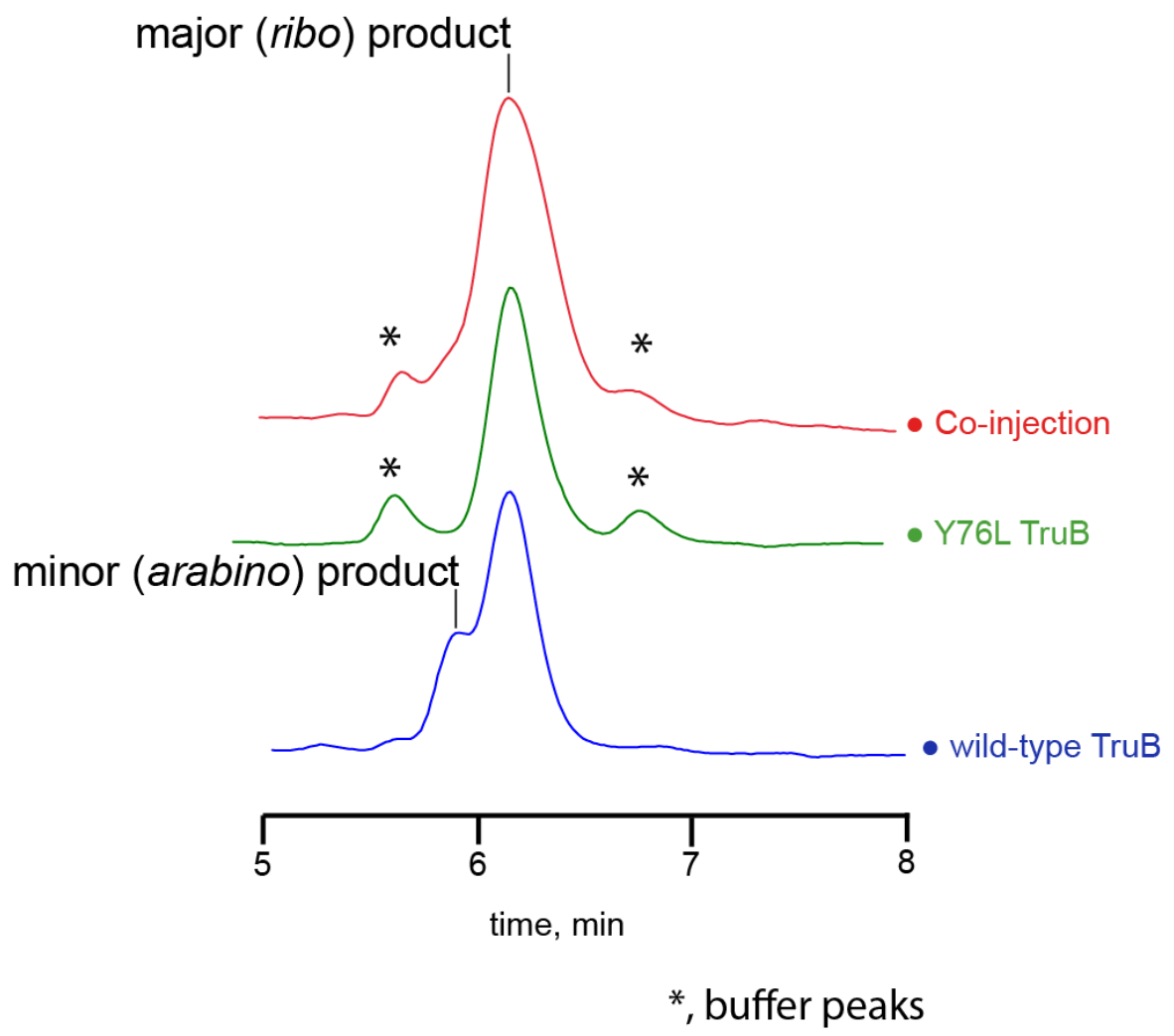

Figure 3.12: Partial HPLC trace of the products of $F^{5} U$ from the action of wild-type (blue) and Y76L (green) TruB. Co-injection results in a stoichiometric increase in the integration for the major product of $\mathrm{F}^{5} \mathrm{U}$. *, buffer peaks. 


\section{SDS-PAGE analysis}

To test whether the variant enzyme can form an adduct with [ $\left.F^{5} U\right] R N A$, Y76L TruB $(10 \mu \mathrm{M})$ was incubated with $\left[\mathrm{F}^{5} \mathrm{U}\right] \mathrm{TSL}(50 \mu \mathrm{M})$ in standard reaction buffer for 3-6 $\mathrm{h}$ at $37^{\circ} \mathrm{C}$. Aliquots of this reaction were analyzed by SDS-PAGE. Similar to the behavior of wild-type TruB, [25] no adduct was observed with Y76L TruB even after $6 \mathrm{~h}$ of incubation with [ $\left.\mathrm{F}^{5} \mathrm{U}\right] \mathrm{TSL}$ (Figure 3.13).

\section{Time course for the formation of $\left[\mathrm{F}^{5} \mathrm{U}^{\star}\right] \mathrm{TSL}$}

To see whether Y76L TruB can achieve multiple turnovers of [F5 U]TSL like wildtype TruB, $\left[F^{5} \mathrm{U}\right] \mathrm{TSL}(50 \mu \mathrm{M})$ was incubated with Y76L TruB $(5-10 \mu \mathrm{M})$ in standard reaction buffer for $12 \mathrm{~h}$ at $37^{\circ} \mathrm{C}$. Aliquots $(10 \mu \mathrm{L})$ of this reaction were withdrawn at regular time intervals, and the RNA was digested to individual nucleosides and analyzed by HPLC. Wild-type TruB (200 nM) completely turns over [ $\left.\mathrm{F}^{5} \mathrm{U}\right] \mathrm{TSL}$ (20 $\mu \mathrm{M})$ within $3 \mathrm{~h}$, [25] but Y76L TruB achieved only $\sim 2.5$ turnovers even after $12 \mathrm{~h}$ (Table 3.1). Also, the enzyme slowed considerably after the first turnover; it is $\sim 600$-fold slower than the wild-type TruB. The observed decrease in the activity of Y76L TruB towards $\left[F^{5} \mathrm{U}\right] \mathrm{TSL}$ raises the question of whether the rate of the reaction is being limited by slow product dissociation. To address this issue, Y76L TruB (10 $\mu \mathrm{M})$ was incubated with $\left[\mathrm{F}^{5} \mathrm{U}^{*}\right] \mathrm{TSL}(20 \mu \mathrm{M})$ in standard reaction buffer for $15 \mathrm{~min}$ at $37^{\circ} \mathrm{C}$ before the addition of $\left[\mathrm{F}^{5} \mathrm{U}\right] \mathrm{TSL}(50 \mu \mathrm{M})$. The pre-incubation led to a $\sim 16$ fold decrease in the rate of formation of $\left[\mathrm{F}^{5} \mathrm{U}^{*}\right] \mathrm{TSL}$ (Figure 3.14, Table 3.2). 


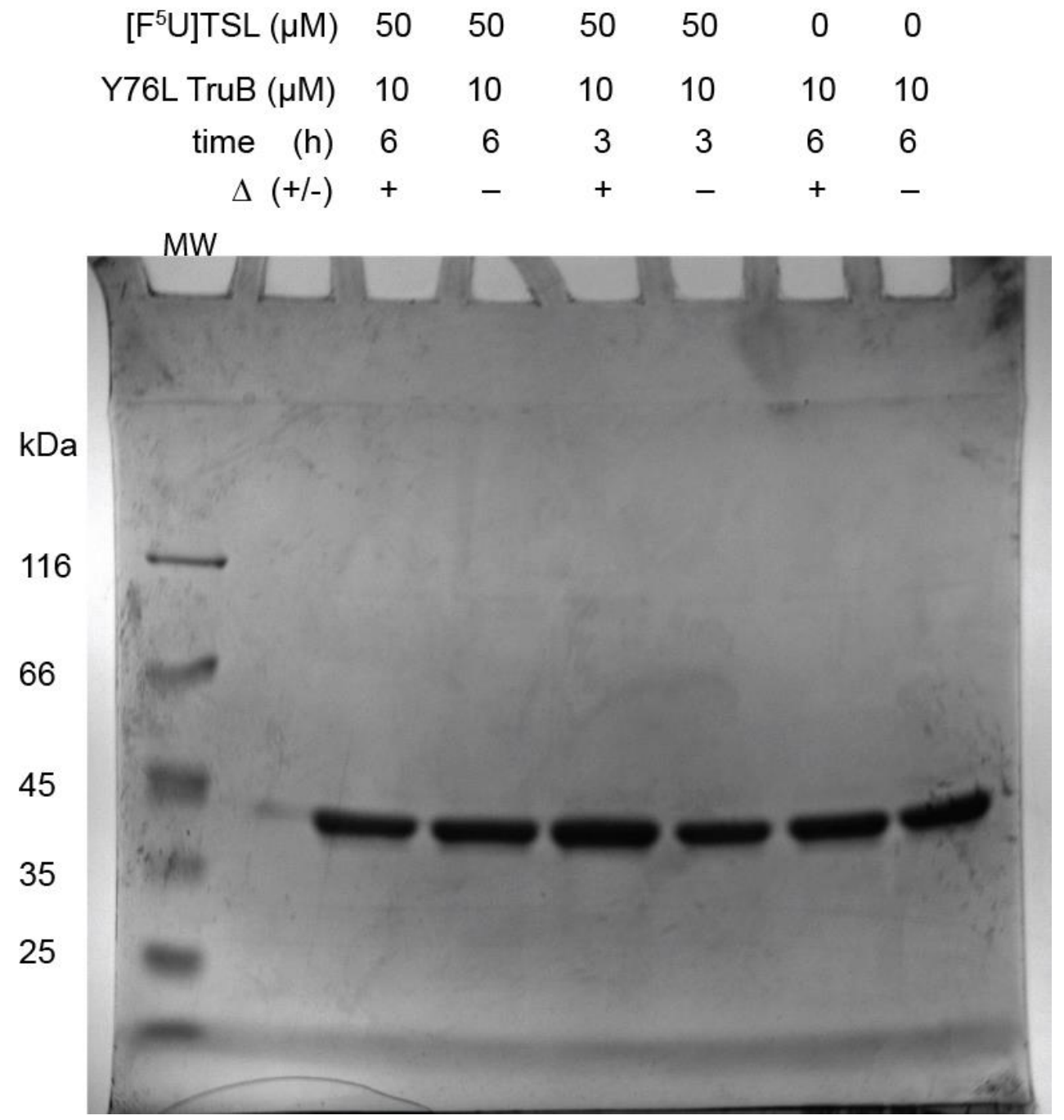

Figure 3.13: SDS-PAGE analysis (10\% gel) of the reaction between $\mathrm{Y76L}$ TruB and $\left[F^{5} \mathrm{U}\right] \mathrm{TSL}$. No adduct band was observed even after prolonged incubation times. MW, EZ-Run ${ }^{\mathrm{TM}}$ protein markers (Fisher Scientific; Waltham, MA). 
Table 3.1: Production of $\left[\mathrm{F}^{5} \mathrm{U}^{\star}\right] \mathrm{TSL}$ observed for different ratios of $\mathrm{Y76L}$ TruB and $\left[\mathrm{F}^{5} \mathrm{U}\right] \mathrm{TSL}$.

\begin{tabular}{cccc}
\hline Y76L TruB, $\mu \mathrm{M}$ & {$\left[\mathrm{F}^{5} \mathrm{U}\right] \mathrm{TSL}, \mu \mathrm{M}$} & time, $\mathrm{h}$ & {$\left[\mathrm{F}^{5} \mathrm{U}^{*}\right] \mathrm{TSL}, \mu \mathrm{M}$} \\
\hline 10 & 50 & 3 & 18 \\
10 & 50 & 6 & 21 \\
10 & 50 & 12 & 25 \\
5 & 50 & 3 & 10 \\
\hline
\end{tabular}




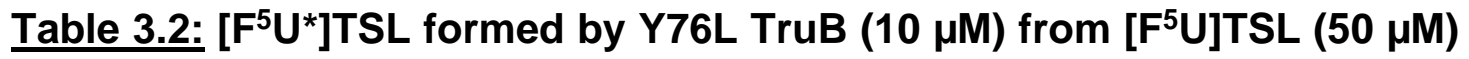
with or without pre-incubation of the enzyme with $\left[F^{5} U^{*}\right] T S L(20 \mu M)$.

\begin{tabular}{cc|c}
\hline \multirow{2}{*}{ time, min } & \multicolumn{2}{c}{$\left[\mathrm{F}^{5} \mathrm{U}^{*}\right] \mathrm{TSL}, \mu \mathrm{M}$} \\
\cline { 2 - 3 } & $\begin{array}{c}\text { reaction without } \\
\text { pre-incubation }\end{array}$ & $\begin{array}{c}\text { reaction after } \\
\text { pre-incubation }\end{array}$ \\
\hline 5 & $7.22 \pm 0.77$ & - \\
10 & $8.26 \pm 1.02$ & $23.04 \pm 0.07$ \\
45 & $12.60 \pm 0.97$ & $25.55 \pm 1.27$ \\
90 & $14.72 \pm 1.40$ & $26.99 \pm 1.34$ \\
150 & $17.47 \pm 2.98$ & $28.78 \pm 1.17$ \\
240 & $19.08 \pm 3.89$ & $29.41 \pm 0.46$ \\
\hline
\end{tabular}


A.

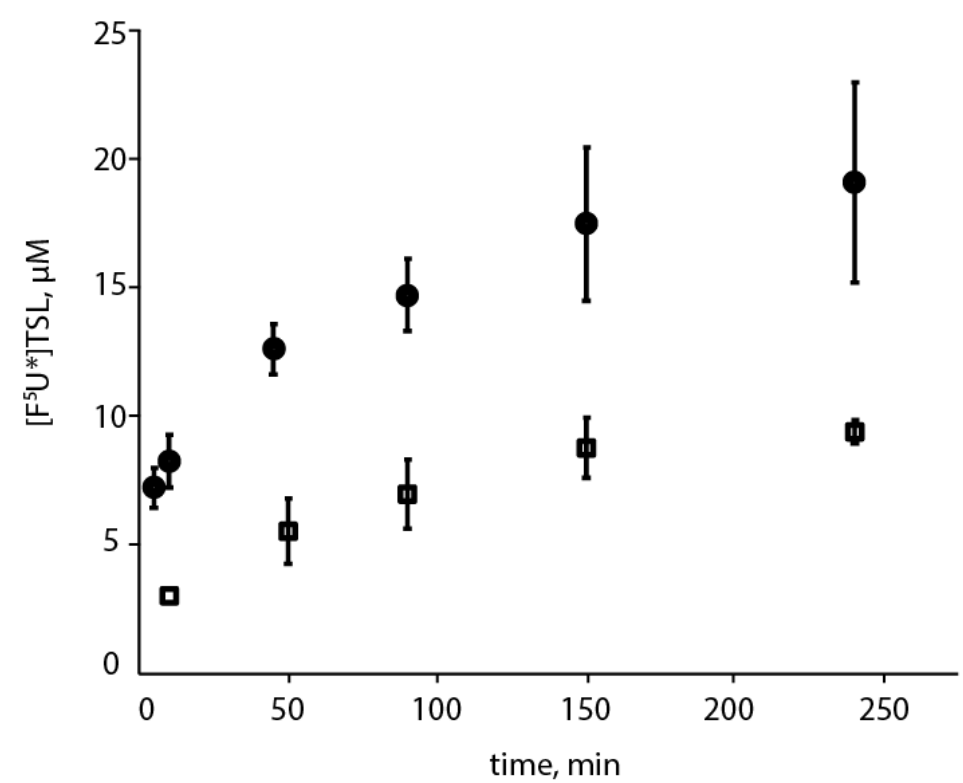

$B$.

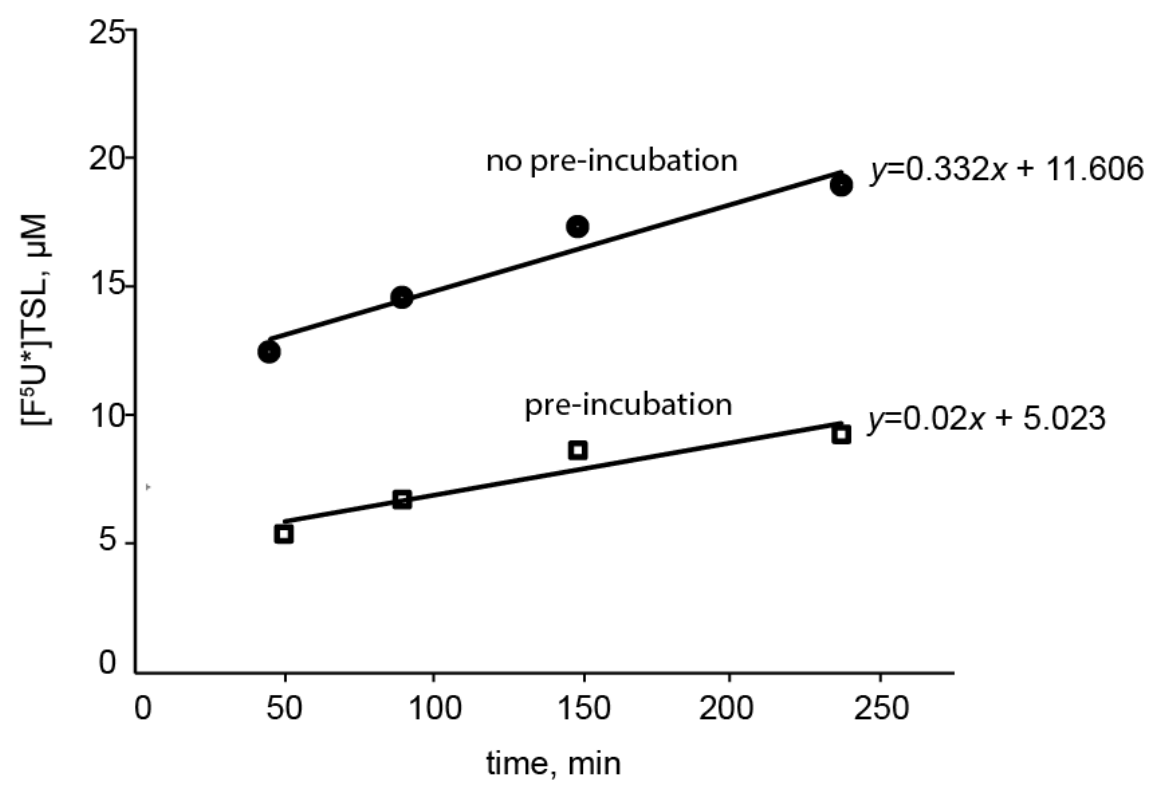

Figure 3.14: Inhibition of $\mathrm{Y76L}$ TruB by $\left[\mathrm{F}^{5} \mathrm{U}^{\star}\right] \mathrm{TSL}$. A, Formation of

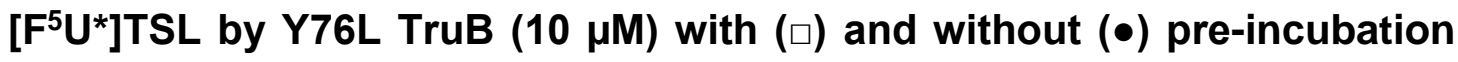
with $\left[\mathrm{F}^{5} \mathrm{U}^{*}\right] \mathrm{TSL}(20 \mu \mathrm{M})$ prior to addition of $\left[\mathrm{F}^{5} \mathrm{U}\right] \mathrm{TSL}(50 \mu \mathrm{M})$. B, The later phase of reaction with $(\square)$ and without $(\bullet)$ pre-incubation. The plotted values for the reaction with pre-incubation ( $\square$ ) are adjusted by subtraction of the $\left[F^{5} U^{*}\right] T S L(20 \mu M)$ originally present. 


\section{Deuterium wash-in}

Y76L TruB $(10 \mu \mathrm{M})$ was incubated with $\left[\mathrm{F}^{5} \mathrm{U}\right] \mathrm{TSL}(40 \mu \mathrm{M})$ in either unlabeled or deuterated standard reaction buffer for $4 \mathrm{~h}$ at $37^{\circ} \mathrm{C}$. A comparison of the product of $\mathrm{F}^{5} \mathrm{U}\left(\mathrm{F}^{5} \mathrm{U}^{*} \mathrm{pC}\right)^{5}$ from the reaction run in labeled versus unlabeled buffer revealed that a low amount of deuterium wash-in occurred (Figure 3.15 and Table 3.3). The isotopic contribution from ${ }^{2} \mathrm{H}$ can be clearly seen for the $\mathrm{M}+1$ and $\mathrm{M}+2$ peaks (Figure 3.16) with the contributions from ${ }^{2} \mathrm{H}$ and ${ }^{13} \mathrm{C}$ clearly resolved (insets). Based on these high-resolution spectra, $4.45 \%$ wash-in was calculated. Repetition of the wash-in experiments, however, showed a lower percentage $(0.52 \%$ and $0.92 \%$ ) of deuterium incorporation into $\mathrm{F}^{5} \mathrm{U}^{*} \mathrm{pC}$ (Table 3.4).

\footnotetext{
${ }^{5}$ The product of $F^{5} U$ was isolated as a dinucleotide with cytidine on the $3^{\prime}$-end $\left(F^{5} U^{\star} p C\right)$. This was because of the inability of $\mathrm{S} 1$ nuclease to cleave after non-planar bases such as $\mathbf{F}^{5} \mathbf{U}^{*}$.
} 


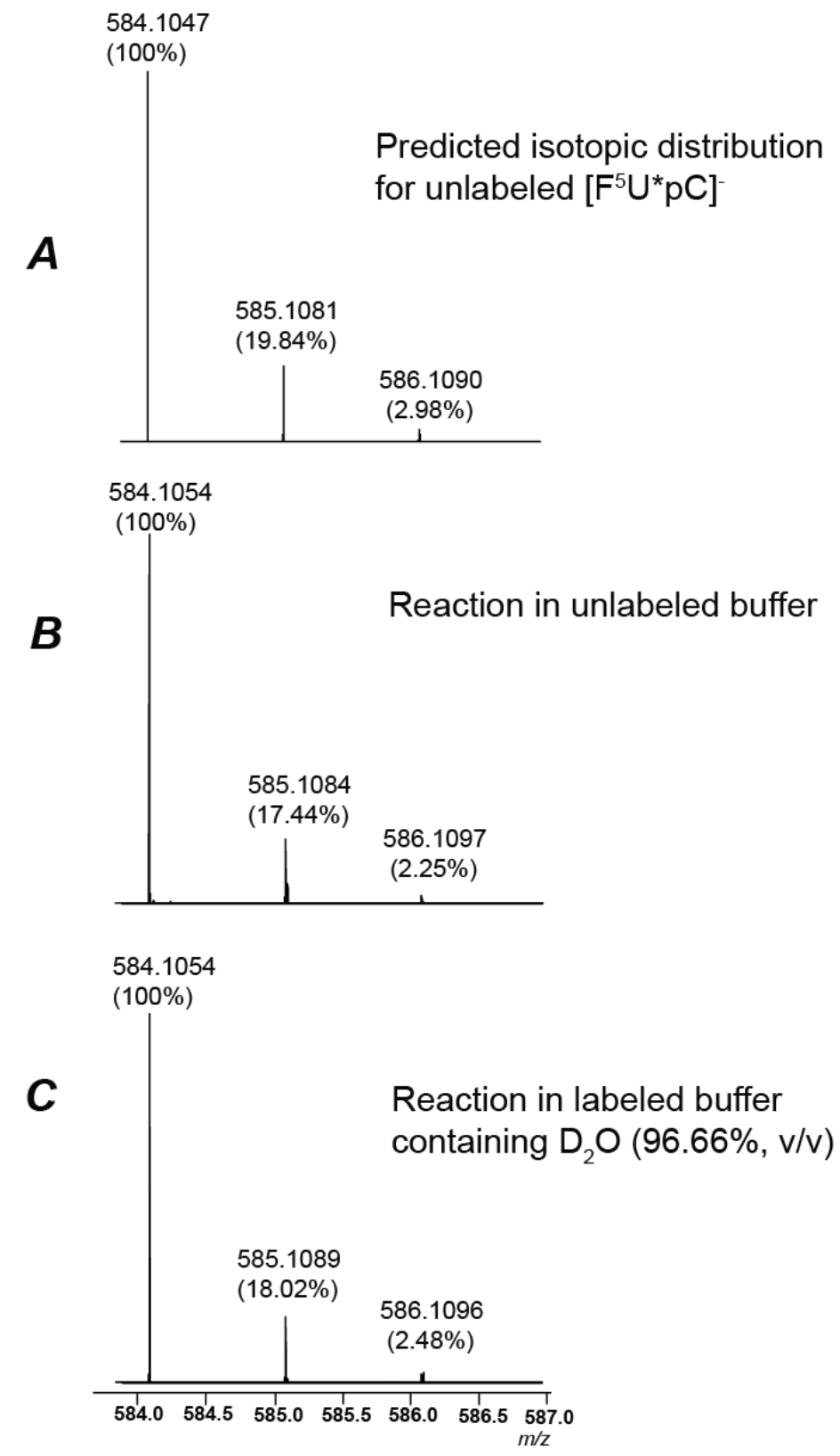

Figure 3.15: Comparative FT-MS of the purified dinucleotide $\mathrm{F}^{5} \mathrm{U}^{*} \mathrm{pC}$. A, Natural abundance isotopic distribution. B, Observed isotopic distribution for the reaction in unlabeled buffer. $\mathrm{C}$, Observed isotopic distribution for the reaction in labeled buffer $\left(96.66 \% \mathrm{D}_{2} \mathrm{O}\right)$. 


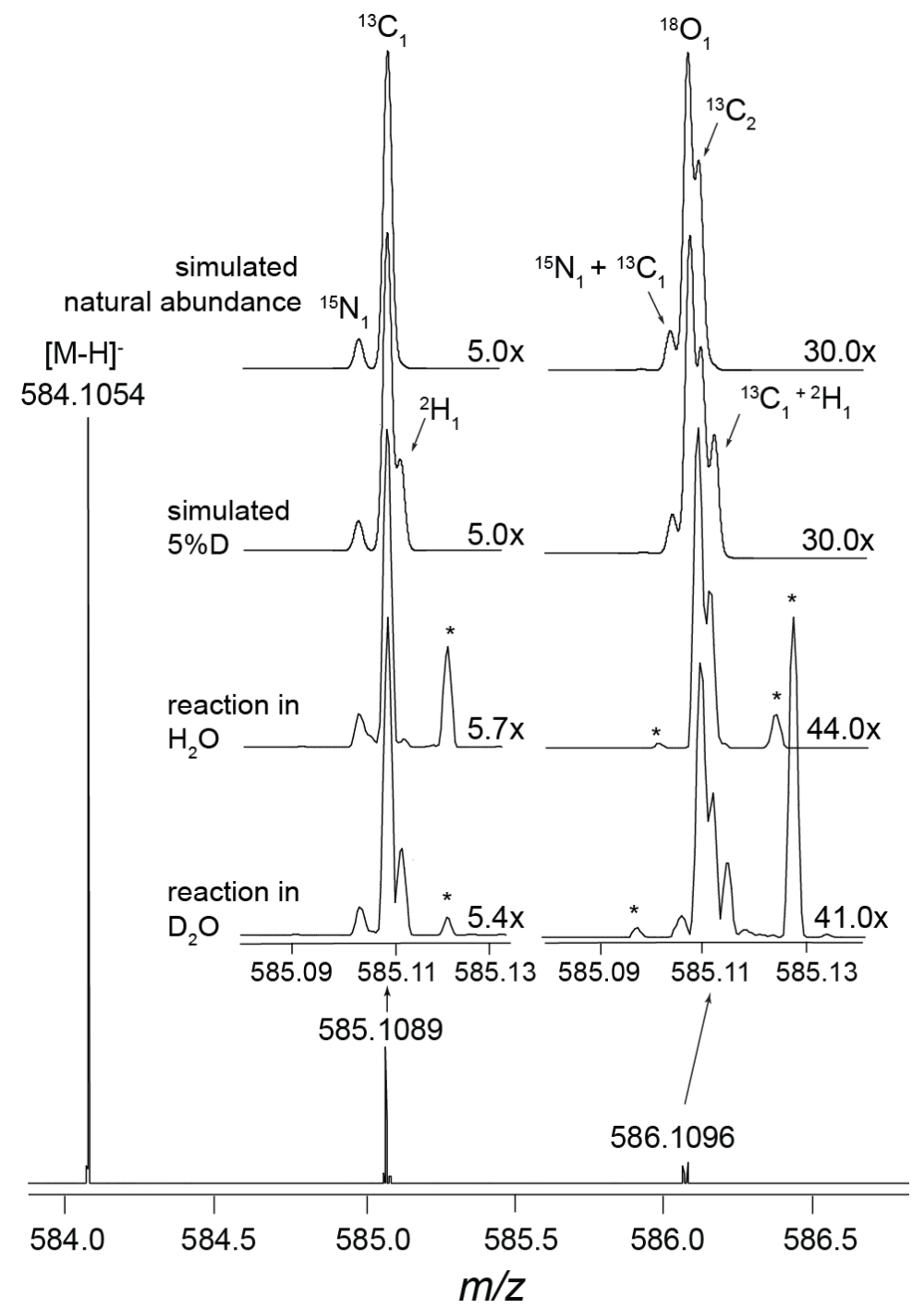

Figure 3.16: High resolution mass spectrum of $\left[\mathrm{F}^{5} \mathrm{U}^{*} \mathrm{pC}\right]$. The inserts show close-up views of the $M+1$ and $M+2$ ion clusters. The spectra for the dinucleotide obtained from the reaction run in unlabeled buffer $\left(\mathrm{H}_{2} \mathrm{O}\right)$ and deuterated buffer $\left(D_{2} O\right)$ are presented along with simulated spectra for natural abundance and for $5 \%$ non-exchangeable deuterium (5\%D). A deuterium incorporation of $4.45 \%$ from the solvent was observed. *, unidentified peaks absent in the control mass spectrum of solvent. 
Table 3.3: Mass spectral analysis (negative mode) of the dinucleotide product $F^{5} U^{*} p C$ obtained from the action of $Y 76 L$ TruB on $\left[F^{5} U\right] T S L$ conducted in unlabeled and labeled buffers. Bolded rows show the contributions from ${ }^{2} \mathrm{H}$; Rl, relative intensity

\begin{tabular}{|c|c|c|c|c|c|c|c|}
\hline \multirow{3}{*}{ Peak } & \multirow{3}{*}{ Description } & \multirow{2}{*}{\multicolumn{2}{|c|}{ Predicted for $\left[F^{5} U^{*} p C\right]$}} & \multicolumn{4}{|c|}{ Observed results } \\
\hline & & & & \multicolumn{2}{|c|}{$\mathrm{H}_{2} \mathrm{O}$ reaction } & \multicolumn{2}{|c|}{$\mathrm{D}_{2} \mathrm{O}$ reaction } \\
\hline & & $m / z$ & RI (\%) & $m / z$ & RI \% & $\mathrm{m} / \mathrm{z}$ & RI \% \\
\hline$M$ & {$[\mathrm{M}-\mathrm{H}]^{-}$} & 584.1047 & 100 & 584.105 & 100 & 584.105 & 100 \\
\hline \multirow[t]{3}{*}{$M+1$} & $+{ }^{15} \mathrm{~N}$ & 585.1017 & 1.85 & 585.102 & 1.84 & 585.103 & 1.61 \\
\hline & $+{ }^{13} \mathrm{C}$ & 585.1081 & 19.84 & 585.108 & 17.44 & 585.109 & 18.02 \\
\hline & $++^{2} \mathrm{H}$ & 585.1109 & 0.48 & 585.112 & 0.45 & 585.112 & 4.94 \\
\hline \multirow[t]{4}{*}{$M+2$} & $+{ }^{15} \mathrm{~N}_{2}$ & 586.1050 & 0.37 & 586.106 & 0.03 & 586.106 & 0.19 \\
\hline & $+{ }^{18} \mathrm{O}$ & 586.1089 & 2.98 & 586.11 & 2.25 & 586.11 & 2.48 \\
\hline & $+{ }^{13} \mathrm{C}_{2}$ & 586.1113 & 1.94 & 586.112 & 1.10 & 586.112 & 1.31 \\
\hline & $+{ }^{13} \mathrm{C}_{1}{ }^{2} \mathrm{H}_{1}$ & 586.1145 & 0.06 & 586.115 & 0.03 & 586.115 & 0.67 \\
\hline
\end{tabular}


Table 3.4: Mass spectral analysis (negative mode) of the dinucleotide product $F^{5} U^{*} \mathrm{pC}$ for the successive trials of wash-in experiments. Highlighted rows indicate the contributions from ${ }^{2} \mathrm{H}$. RI, relative intensity.

\begin{tabular}{|c|c|c|c|c|c|c|c|}
\hline \multirow{3}{*}{ Peak } & \multirow{3}{*}{ Description } & \multirow{2}{*}{\multicolumn{2}{|c|}{ Predicted for $\left[F^{5} U^{*} p C\right]$}} & \multicolumn{4}{|c|}{ Observed results } \\
\hline & & & & \multicolumn{2}{|c|}{$\mathrm{H}_{2} \mathrm{O}$ reaction } & \multicolumn{2}{|c|}{$\mathrm{D}_{2} \mathrm{O}$ reaction } \\
\hline & & $m / z$ & RI \% & $m / z$ & RI (\%) & $m / z$ & RI (\%) \\
\hline & & & Trial 2 & & & & \\
\hline M & {$[\mathrm{M}-\mathrm{H}]^{-}$} & 584.105 & 100 & 584.107 & 100 & 584.105 & 100 \\
\hline \multirow[t]{3}{*}{$M+1$} & $+{ }^{15} \mathrm{~N}$ & 585.102 & 1.85 & 585.103 & 1.79 & 585.104 & 0.50 \\
\hline & $+{ }^{13} \mathrm{C}$ & 585.108 & 19.84 & 585.111 & 17.54 & 585.110 & 12.35 \\
\hline & $+^{2} \mathrm{H}$ & 585.111 & 0.48 & 585.113 & - & 585.113 & 0.52 \\
\hline \multirow[t]{4}{*}{$M+2$} & $+{ }^{15} \mathrm{~N}_{2}$ & 586.105 & 0.37 & 586.106 & 0.04 & 586.107 & 0.05 \\
\hline & $+{ }^{18} \mathrm{O}$ & 586.109 & 2.98 & 586.111 & 0.10 & 586.112 & 1.18 \\
\hline & $+{ }^{13} \mathrm{C}_{2}$ & 586.111 & 1.94 & 586.112 & - & 586.114 & 0.55 \\
\hline & $+{ }^{13} \mathrm{C}_{1}{ }^{2} \mathrm{H}_{1}$ & 586.115 & 0.06 & 586.117 & 0.04 & 586.117 & 0.02 \\
\hline \multicolumn{8}{|c|}{ Trial 3} \\
\hline M & {$[\mathrm{M}-\mathrm{H}]^{-}$} & 584.105 & 100 & 584.107 & 100 & 584.107 & 100 \\
\hline \multirow[t]{3}{*}{$M+1$} & $+{ }^{15} \mathrm{~N}$ & 585.102 & 1.85 & 585.103 & 1.79 & 585.105 & 0.81 \\
\hline & $+{ }^{13} \mathrm{C}$ & 585.108 & 19.84 & 585.111 & 17.54 & 585.110 & 14.62 \\
\hline & $+{ }^{2} \mathrm{H}$ & 585.111 & 0.48 & 585.113 & 0.05 & 585.113 & 0.97 \\
\hline \multirow[t]{4}{*}{$M+2$} & $+{ }^{15} \mathrm{~N}_{2}$ & 586.105 & 0.37 & 586.106 & 0.04 & 586.108 & 0.11 \\
\hline & $+{ }^{18} \mathrm{O}$ & 586.109 & 2.98 & 586.111 & 0.10 & 586.112 & 1.19 \\
\hline & $+{ }^{13} \mathrm{C}_{2}$ & 586.111 & 1.94 & 586.112 & - & 586.114 & 0.59 \\
\hline & $+{ }^{13} \mathrm{C}_{1}{ }^{2} \mathrm{H}_{1}$ & 586.115 & 0.06 & 586.117 & - & 586.117 & 0.03 \\
\hline
\end{tabular}




\section{Discussion}

In silico analysis showed that the Y76L substitution results in a more open TruB active site that may provide greater access to solvent molecules and thus allow deuterium wash-in. A plasmid encoding Y76L TruB was generated and used to overexpress the variant enzyme. Purified Y76L TruB was stored under slightly modified conditions since activity was lost under the storage conditions used for wild-type TruB. [86]

The initial characterization of Y76L TruB by Phannachet et al. did not include denaturing PAGE analysis to test if this variant forms an adduct when incubated with [ $\left.\mathrm{F}^{5} \mathrm{U}\right] \mathrm{TSL}$. As with wild-type TruB, no adduct was observed for Y76L TruB on SDS-PAGE gels, even after prolonged incubation with [ $\left.\mathrm{F}^{5} \mathrm{U}\right] \mathrm{TSL}$ (Figure 3.14). Also, reverse phase HPLC analysis of product nucleotides showed that Y76L TruB handles $\left[F^{5} \mathrm{U}\right] \mathrm{TSL}$ and forms a rearranged, hydrated product from $\mathrm{F}^{5} \mathrm{U}$. However, in contrast to wild-type TruB, Y76L TruB forms a single product, which was confirmed as the major (ribo) product generated by the action of wild-type TruB (Figure 3.1). One explanation for the formation of a single product of $F^{5} \mathrm{U}$ could be that the Tyr to Leu substitution induces a change in active site geometry that alters the relative positions of the $\mathrm{F}^{5} \mathrm{U}$ and conserved Asp. In this scenario, the conserved Asp may no longer be able to access the ribose ring from the "bottom" face to yield the arabino product of $\mathrm{F}^{5} \mathrm{U}$. However, this hypothesis cannot be confirmed because a cocrystal structure of $\mathrm{Y} 76 \mathrm{~L}$ TruB with $\left[\mathrm{F}^{5} \mathrm{U}\right] \mathrm{TSL}$ has not been reported, and the limitations of the in silico analysis $[83,84]$ do not allow 
confidence that it can deliver definitive changes in the positioning of the active site groups.

Y76L TruB catalyzes the reaction of $F^{5} \mathrm{U} \sim 600$ fold slower than does wildtype TruB, and the first turnover occurs much faster (Table 3.1, Figure 3.14). This slow activity of Y76L TruB towards [F5] $\mathrm{F}^{5} \mathrm{TSL}$ could be a case of product inhibition that is caused either by the slow dissociation of $\left[\mathrm{F}^{5} \mathrm{U}^{*}\right] \mathrm{TSL}$ from the enzyme after the initial turnover or a binding competition between $\left[\mathrm{F}^{5} \mathrm{U}^{\star}\right] \mathrm{TSL}$ and $\left[\mathrm{F}^{5} \mathrm{U}\right] \mathrm{TSL}$. To answer this question, $\mathrm{Y} 76 \mathrm{~L}$ TruB was pre-incubated with $\left[\mathrm{F}^{5} \mathrm{U}^{*}\right] \mathrm{TSL}(1: 2)$ in standard reaction buffer followed by assaying with [ $\left.\mathrm{F}^{5} \mathrm{U}\right] \mathrm{TSL}$. HPLC analysis of this reaction showed a $\sim 16$ fold reduction in the initial rates of formation of $\left[\mathrm{F}^{5} \mathrm{U}^{\star}\right] \mathrm{TSL}$ (Figure 3.14, panel B), a result that indicates competition between the $\left[F^{5} U\right] T S L$ and its product.

\section{Deuterium wash-in}

\section{High resolution mass spectrometry}

A mass spectrum consists of a sum of signals from species of various possible isotopologues (for example, ${ }^{13} \mathrm{C},{ }^{15} \mathrm{~N},{ }^{2} \mathrm{H}$, etc.). The isotopic distribution for each singly charged molecular species consists of peaks spaced $1 \mathrm{~m} / \mathrm{z}$ apart. The monoisotopic peak, which is the isotopologue with only the most abundant isotope of each element, uniquely reflects elemental composition as every other peak in the mass spectrum represents contributions from different combinations of less abundant isotopes of the constituent elements. For example, a species of the monoisotopic mass $+2 \mathrm{~m} / \mathrm{z}(\mathrm{M}+2)$ can represent an isotopic combination of two 
${ }^{13} \mathrm{C}$, two ${ }^{15} \mathrm{~N}$, one ${ }^{13} \mathrm{C}$ and one ${ }^{15} \mathrm{~N}$, two ${ }^{2} \mathrm{H}$, etc. Such elemental combinations, however, differ from each other by a few $\mathrm{mDa}$, and a mass spectrometer of sufficiently high resolution can distinguish the contribution from each element. In the current study, the contribution from ${ }^{2} \mathrm{H}$ is at issue.

\section{Deuterium incorporation into the $\left[F^{5} U^{*}\right] T S L$}

Deuterium wash-in was anticipated because the in silico analysis-despite its limitations-clearly indicated a more open active site in Y76L TruB. The observed $4.45 \%$ deuterium incorporation bore out this prediction (Figure 3.16; Table 3.3). Replicates were run to confirm the low level of wash-in, and they showed even lower levels $(0.52 \%$ and $0.92 \%)$ of deuterium incorporation into the product of $F^{5} U$. The significance of these minute levels of wash-in must be viewed with skepticism. Although substantial wash-in would have been informative, its absence is not because the removed proton may remain occluded from the solvent even in the Y76L variant. A more definitive approach to test the glycal mechanism is to seek for a primary kinetic isotope effect by comparing the reaction rates of substrates prepared with $\left[2^{\prime}-2 \mathrm{H}\right] \mathrm{U}$ with those of unlabeled substrates, which is presented in Chapter 4. 


\section{CHAPTER 4}

\section{DEUTERIUM KINETIC ISOTOPE EFFECT STUDIES TO PROBE THE GLYCAL MECHANISM}

Pseudouridine synthases ( $\Psi$ synthases) convert uridine $(U)$ to its $C$-glycoside isomer pseudouridine $(\Psi)$. They are classified into six different families that share no statistically significant global sequence similarity but have identical folds and are thus thought to have resulted from divergent evolution. [18] An active site aspartic acid residue conserved among all $\Psi$ synthases (hereafter, the 'conserved Asp') is absolutely essential for the activity. [64] $\Psi$ synthases TruA and RluA get irreversibly inhibited by 5-fluorouridine-containing RNA ([F5]RNA), [29, $30,36]$ which led to the proposal of the 'Michael mechanism', in which the conserved Asp forms a Michael adduct with C6 of the pyrimidine ring (Figure 4.1) [36].The alternative 'acylal mechanism' involves the conserved Asp as a nucleophile, but with attack at $\mathrm{C} 1^{\prime}$ of the ribose ring to form an acylal intermediate (Figure 4.2) [36]

$\Psi$ synthases differ in their action towards $\left[F^{5} U\right] R N A$. While TruA and RluA get irreversibly inhibited and form an adduct that appears covalent by denaturing 

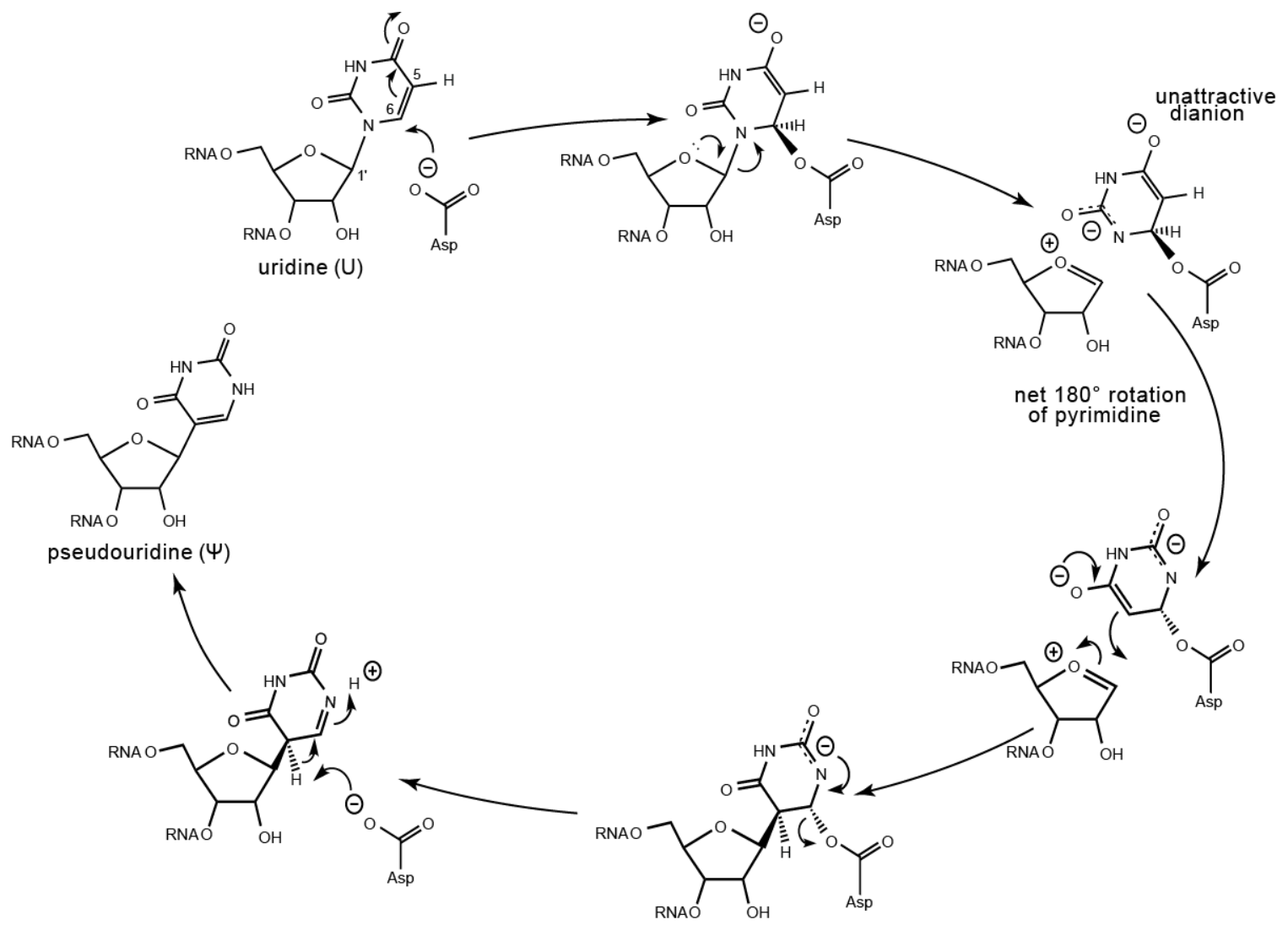

Figure 4.1: The 'Michael mechanism' for $\Psi$ synthases. The conserved Asp makes a nucleophilic attack at $\mathbf{C 6}$ to form a Michael adduct. $\mathrm{N}$-glycosidic bond cleavage followed by a net $180^{\circ}$ rotation of the adducted pyrimidine repositions it for the subsequent $C$-glycoside formation. Expulsion of the conserved Asp followed by the deprotonation of C5 generates $\Psi$. 


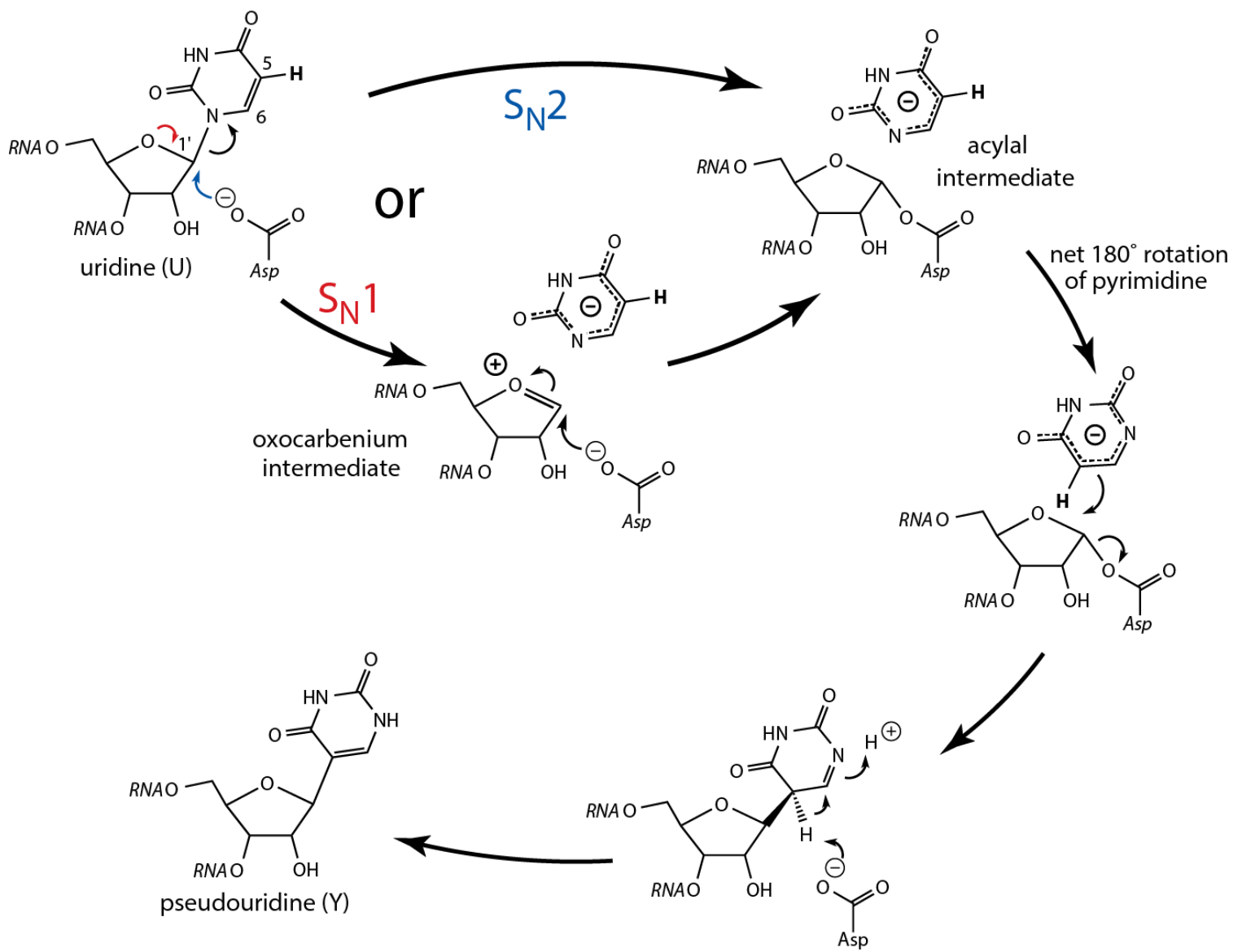

Figure 4.2: The 'acylal mechanism' for $\Psi$ formation. This mechanism begins with the conserved Asp making a nucleophilic attack at $\mathrm{C1}^{\prime}$ ' of the ribose ring, either through a concerted or step-wise process, thereby displacing the pyrimidine ring. The uracilate anion rotates to reposition itself to effect $C$-glycoside formation. The expelled Asp deprotonates C5 to generate $\Psi$. 
PAGE analysis, $[30,36]$ E. coli TruB does not get inhibited and turns over $\left[\mathrm{F}^{5} \mathrm{U}\right] \mathrm{TSL}^{6}$ into two rearranged and hydrated products (hereafter, the 'major' and 'minor' products of $F^{5} U$ ). [25] NMR experiments by Miracco and Mueller showed that TruB and RluA form the same products of $\mathrm{F}^{5} \mathrm{U}$ which differ in the sugar rather than the pyrimidine ring: the major product of $\mathrm{F}^{5} \mathrm{U}$ was the ribo isomer previously found in the cocrystal structure of TruB and $\left[F^{5} U\right] R N A$ [40] whereas the minor product was the arabino isomer (Figure 3.1). [43]

The change in configuration at $\mathrm{C}^{\prime}$ ' requires epimerization during formation of the minor versus the major product. C2' must be deprotonated to form a glycal intermediate followed by reprotonation from the "bottom" face. (Figure 4.3) [43] The deprotonation of C2' can be achieved either by the conserved Asp or $\mathrm{O}^{2}$ of the pyrimidine ring. [87] However, the conserved Asp is the only acid/base group positioned near enough to $\mathrm{C}^{2}$ ' to donate a proton to its "bottom" face-an observation that strongly argues against the Michael mechanism since the conserved Asp is tied up as an ester.

The arabino product of $\mathrm{F}^{5} \mathrm{U}$ is still consistent with the acylal mechanism (Figure 3.2). [43] The diminished nucleophilicity of the anion of 5-fluorouracil results in an increased lifetime for the acylal intermediate and the oxocarbenium species with which it is in equilibrium. [43] The increased acidity of C2' in the oxocarbenium species makes its deprotonation by the detached conserved Asp

\footnotetext{
${ }^{6} \Psi$ synthase TruB was previously shown to handle stem-loop substrate (TSL) as well as the full length tRNA substrate. [29] The same is true for RluA with ASL. [30]
} 
easier, and reprotonation of $\mathrm{C}^{\prime}$ from the opposite face results in the arabino product of $\mathrm{F}^{5} \mathrm{U}$ (Figure 3.2).

A glycal intermediate along the $\Psi$ synthase reaction with $U$ opens up a new mechanistic possibility, the 'glycal mechanism' (Figure 4.3), which can easily explain both the major and minor products of $\mathrm{F}^{5} \mathrm{U}$ (Figure 4.4) and is precedented by uridine phosphorylase [87]. With normal substrate (containing $U$ ), the mechanism proceeds through the deprotonation of $\mathrm{C}^{\prime}$ either by the conserved Asp or by the $\mathrm{O}^{2}$ of the pyrimidine ring to eliminate the anion of uracil and form the glycal intermediate. Following rotation of the detached pyrimidine ring and $C$ glycoside formation with reprotonation of C2', deprotonation of C5 by the conserved Asp generates $\Psi$.

If the conserved Asp deprotonates C2', the removed proton resides temporarily on the Asp, where it may be prone to exchange with the solvent protons and therefore provide strong evidence for a glycal intermediate (Figure 3.5). [79, 80] With TruB and RluA, deuterium wash-in studies conclusively ruled out such exchange with both $\mathrm{U}$ - and $\mathrm{F}^{5} \mathrm{U}$-containing RNA substrates. Wash-in experiments with the carefully chosen $\mathrm{Y} 76 \mathrm{~L}$ TruB that has a more open active site resulted in a very low $(<4.5 \%)$ deuterium incorporation into the products of $\mathrm{F}^{5} \mathrm{U}$ (Chapter 3$)$. The lack of wash-in during the formation of minor product of $\mathrm{F}^{5} \mathrm{U}(25-33 \%$ of total products) clearly shows that the proton removed from C2' is rigorously occluded from bulk solvent on the time scale of reaction. The same scenario for the conversion of $U$ to $\Psi$ or $F^{5} U$ to the major product-neither of which requires deprotonation of $\mathrm{C2}^{\prime}$-leaves the lack of wash-in consistent with the glycal 


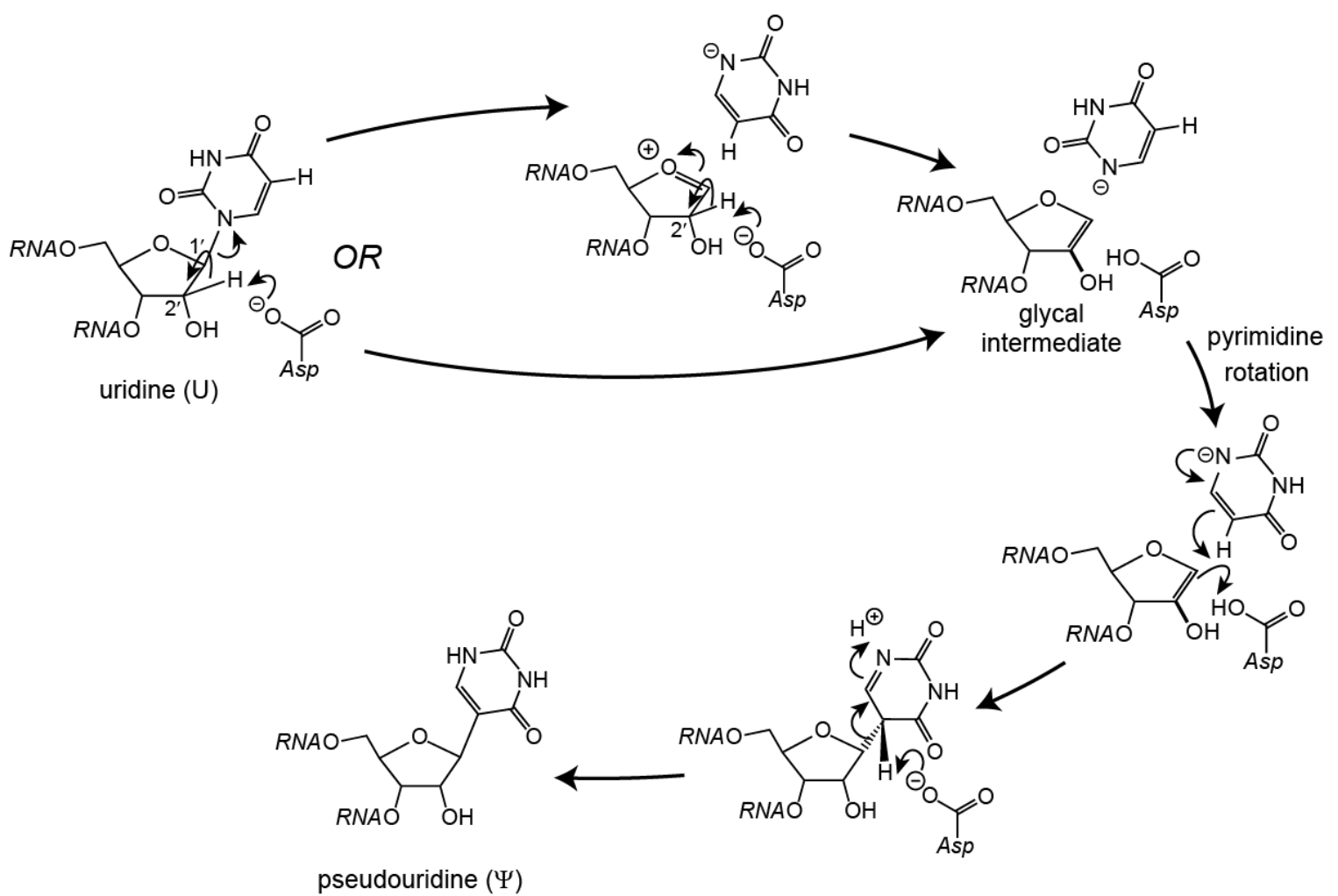

Figure 4.3: The proposed 'glycal mechanism' for $\Psi$ formation. The conserved Asp initiates the reaction by deprotonating C2' that leads to a glycal intermediate. After the C-glycoside rearrangement, $\mathrm{C2}^{\prime}$ is reprotonated by the conserved Asp. 


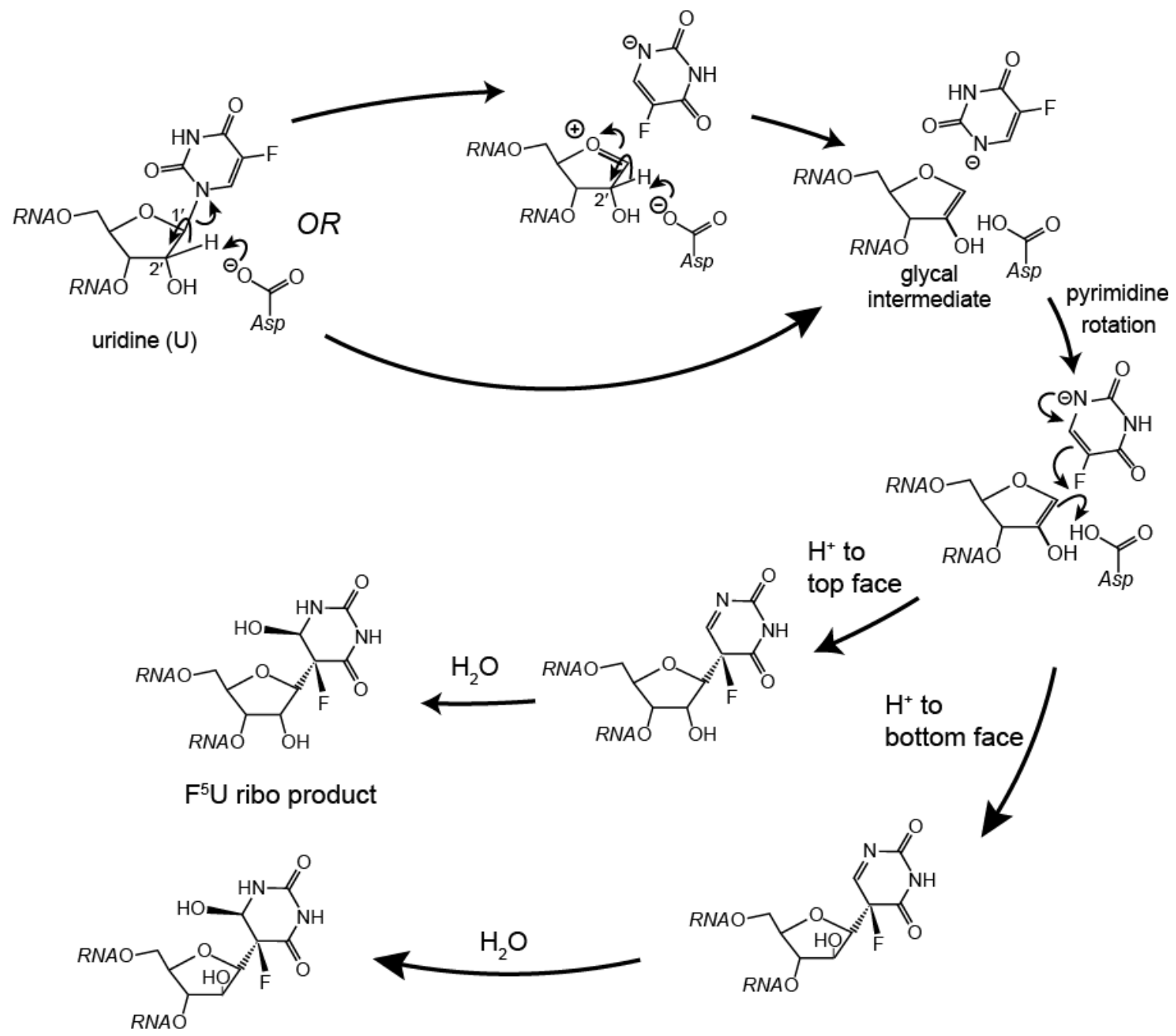

$\mathrm{F}^{5} \mathrm{U}$ arabino product

Figure 4.4: The glycal mechanism with [F5]RNA. Following the deprotonation of C2' by the conserved Asp that leads to the glycal intermediate formation, reprotonation from the bottom face of the C2' would result in the observed arabino product of $\mathrm{F}^{5} \mathrm{U}$. 
mechanism. A more direct and definitive approach than wash-in was sought to obtain evidence for the glycal mechanism.

Deuterium kinetic isotope effect

If the $\Psi$ synthase reaction proceeds through a glycal intermediate, deprotonation or reprotonation of $\mathrm{C}^{\prime}$ (or both) may be partially rate-limiting. In this case, substituting the proton on $\mathrm{C2}^{\prime}$ of $U$ and $\mathrm{F}^{5} \mathrm{U}$ with deuterium (Figure 4.5) should display a primary, deuterium kinetic isotope effect ( $\left.{ }^{2} \mathrm{KIE}\right)$, [88] manifested by a reduction in rate. To test this scenario, stem-loop substrates for TruB and RluA were prepared with $\left[2^{\prime}-2 \mathrm{H}\right] \mathrm{U}$, and their rates were compared with unlabeled substrates. 


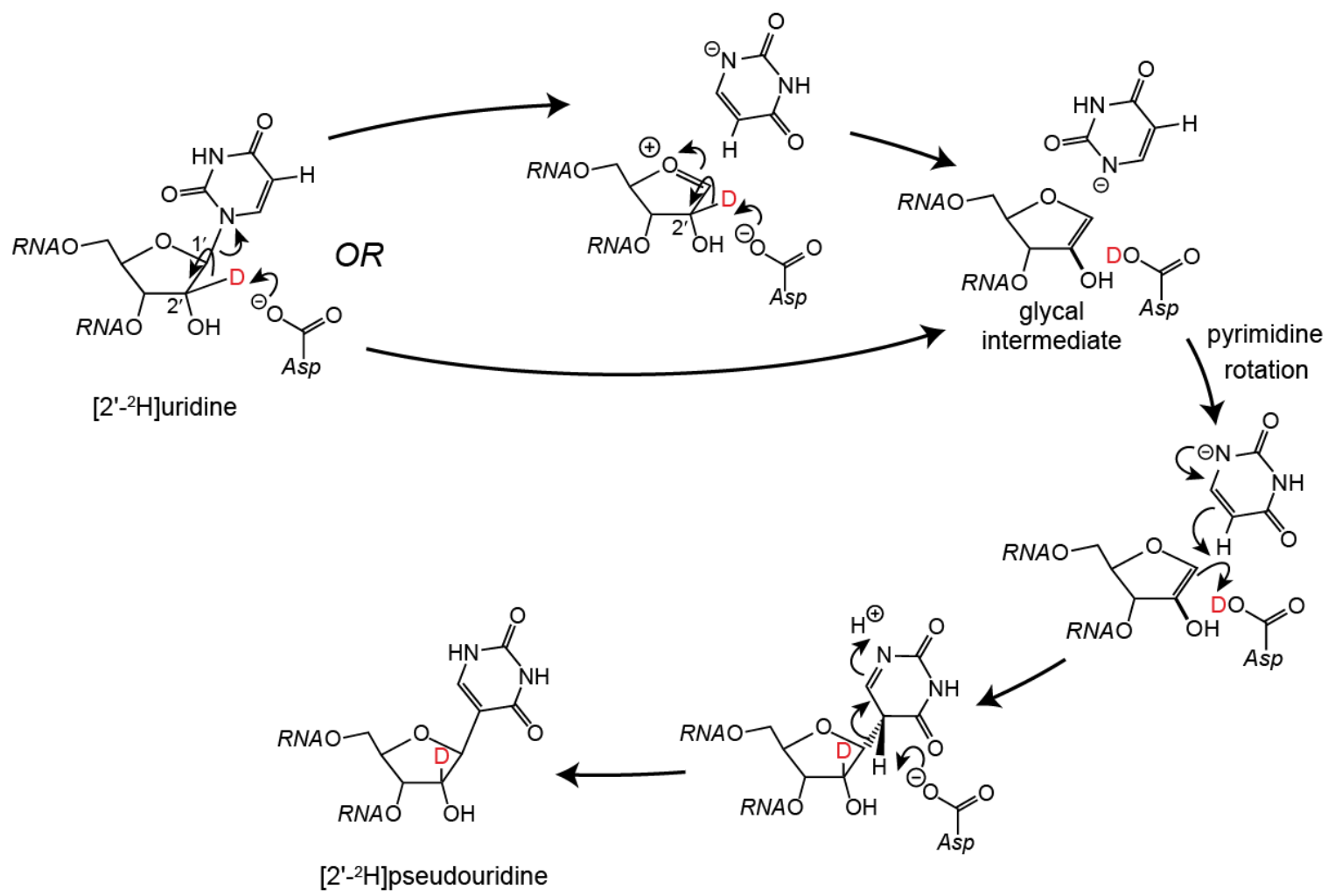

Figure 4.5: The glycal mechanism with $\left[2^{\prime}-{ }^{2} \mathrm{H}\right] \mathrm{U}$ containing substrate. If either deprotonation or reprotonation of $\mathrm{C2}^{\prime}$ is partially rate limiting, a primary ${ }^{2} \mathrm{KIE}$ will be observed. 


\section{Experimental}

All standard chemicals, unless specified were purchased from Fisher Scientific (Pittsburgh, PA) or Sigma Aldrich (Milwaukee, WI). [2'-2H]ribose was purchased from Omicron Biochemicals, Inc. (South Bend, IN). Restriction endonucleases $\mathrm{Ndel}$ and $\mathrm{BamHI}$ and thermostable inorganic pyrophosphatase were purchased from New England BioLabs (Ipswich, MA). Phosphoenolpyruvate (PEP) was purchased from Chem-Impex International (Wood Dale, IL). Pyruvate kinase/lactate dehydrogenase enzyme cocktail, pyruvate kinase II from rabbit muscle, ribose 5-phosphate barium salt (R5P•Ba), Dowex-50 $\left(\mathrm{H}^{+}\right.$form $)$, and Norit ${ }^{\circledR}$ and Darco G-60 activated charcoal were obtained from Sigma Aldrich (Milwaukee, WI). The Dowex-50 $\left(\mathrm{H}^{+}\right.$form $)$was cleaned by the method of Cleland. [89] Prior to use, the activated charcoal $(2 \mathrm{~g})$ was mixed with $0.01 \mathrm{~N} \mathrm{HCl}(30 \mathrm{~mL})$; the mixture was centrifuged $(8000 \mathrm{~g}, 15 \mathrm{~min})$, and the supernatant was discarded. Yeast myokinase was purchased from CalBiochem (Billerica, MA). Amicon DIAFLO ultrafiltration units were purchased from Millipore Corporation (Bedford, MA). Bond Elut C8 solid phase extraction cartridges $(5 \mathrm{~g}, 20 \mathrm{~mL})$ were obtained from Agilent (Santa Clara, CA). DNA oligonucleotides were purchased from Integrated DNA Technologies (Coralville, IA). Ribonucleotide triphosphates (rNTPs) were purchased from Promega (Madison, WI), and T7 RNA polymerase was purchased from Epicentre biotechnologies (Madison, WI). Stop RNase Inhibitor RX was purchased from 5 PRIME, Inc. (Gaithersburg, MD), and TURBO ${ }^{\mathrm{TM}}$ DNase was purchased from Life Technologies (Carlsbad, CA). Phosphoribosyl pyrophosphate (PRPP) was freshly isolated by the method of Gross et al. [90] All coupled 
enzymatic activity assays were performed with a $D U^{\circledR} 800$ Series UV/Vis spectrophotometer (Beckman Coulter; Pasadena, CA) equipped with a six cell transporter and a Peltier temperature controller. NMR spectra were acquired using a 400-MR spectrometer equipped with a $5 \mathrm{~mm}$ direct HX z-PFG broadband probe (Varian Inc., Palo Alto, CA)

\section{Enzymatic synthesis of $\left[2^{\prime}-{ }^{2} \mathrm{H}\right]$ UTP}

\section{Subcloning, overexpression and purification}

Ribokinase. The plasmid (pET22-HT) bearing the ribokinase gene (rbsK) was generously provided by J. Williamson, [91, 92] but it did not properly express ribokinase. DNA sequencing revealed an overhang after the stop codon and an inverted duplication at the 5'-end. To rectify these errors, Ndel and BamHI restriction sites were introduced at the $5^{\prime}$ - and $3^{\prime}$-ends of rbsK, respectively, by PCR amplification with the following primers: 5'GCTCCTCATATGCAAAACGCAGGCAGCC-3' (forward), and 5'GCTTCGGGATCCTCACCTCTGCCTGT-3' (reverse). The PCR product was digested with both Ndel and BamHI and ligated into pET-15b (Novagen; Billerica, MA) opened with the same restriction enzymes to create pUL600 for the expression of ribokinase with $\mathrm{N}$-terminal $\mathrm{His}_{6} \bullet$ tag. The proper insertion of $r b s \mathrm{~K}$ into the plasmid was verified by DNA sequencing. BLR(DE3) pLysS was transformed with pUL600, and ribokinase was overexpressed and purified over Ni-NTA resin (QIAGEN) according to a published protocol. [64] Purified fractions of ribokinase were tested for activity, pooled, concentrated, and dialyzed overnight into the final 
storage buffer, which is $50 \mathrm{mM}$ phosphate buffer, $\mathrm{pH} 7.5$, containing sodium chloride $(150 \mathrm{mM})$ and glycerol $(50 \%, \mathrm{v} / \mathrm{v})$, for storage at $-20^{\circ} \mathrm{C}$ until needed.

PRPP synthetase and uracil phosphoribosyl transferase (UPRTase). The plasmids encoding Salmonella typhimirium PRPP synthetase and E. coliUPRTase were generously provided by S. Van Lanen. [93] Both plasmids were based on pET-30a (+) (Novagen) so that the encoded proteins are expressed with an Nterminal His6 ${ }^{\bullet}$ tag. Following transformation of $B L R(D E 3)$ pLysS cells with these plasmids, PRPP synthetase and UPRTase were overexpressed and purified over Ni•NTA resin. Column fractions were assayed for activity, and enzyme-bearing fractions were pooled, concentrated, and stored $-20{ }^{\circ} \mathrm{C}$ in $50 \mathrm{mM}$ sodium phosphate buffer, $\mathrm{pH} 7.5$, containing sodium chloride $(300 \mathrm{mM})$ and glycerol $(50 \% \mathrm{v} / \mathrm{v})$.

\section{Ribokinase assay}

The activity of ribokinase (Figure 4.6) was determined using an assay coupled to the consumption of $\mathrm{NADH}$. [90, 92] The reaction mixture $(1 \mathrm{~mL})$, was $50 \mathrm{mM}$ Tris $\bullet \mathrm{HCl}$ buffer, $\mathrm{pH} 7.5$, containing D-ribose $(50 \mathrm{mM})$, potassium chloride (100 mM), magnesium chloride (10 mM), NADH (0.2 mM), ATP (3 mM), PEP (1

$\mathrm{mM})$, pyruvate kinase $(3.3 \mu \mathrm{L}, 2 \mathrm{U})$, and lactate dehydrogenase $(3.3 \mu \mathrm{L}, 2 \mathrm{U})$. The cuvette containing the reaction mixture was inserted into the spectrophotometer and held at $25{ }^{\circ} \mathrm{C}$ until a steady base line was observed at $340 \mathrm{~nm}$. Ribokinase $(<1 \mu \mathrm{L}, 1 \mu \mathrm{g})$ was then added, and the contents of the cuvette were mixed by inversion. The change in $\mathrm{A}_{340}$ was monitored with time, and the rate of change and $\varepsilon_{340}$ of $\mathrm{NADH}\left(6220 \mathrm{M}^{-1} \cdot \mathrm{cm}^{-1}\right)$ was used to calculate ribokinase activity (Table 4.1). 


\section{$\mathrm{R} 5 \mathrm{P} \cdot \mathrm{Na}$}

$\mathrm{R} 5 \mathrm{P} \cdot \mathrm{Ba}(100 \mathrm{mM}, 1 \mathrm{~mL})$ was exchanged into its sodium form $(\mathrm{R} 5 \mathrm{P} \cdot \mathrm{Na})$ by passing it through column $(2 \times 1 \mathrm{~cm})$ of Dowex-50 $\left(\mathrm{Na}^{+}\right.$form $)$. R5P $\cdot \mathrm{Na}$ was quantitated by dephosphorylating it with alkaline phosphatase and measuring the concentration of the released inorganic phosphate by the Ames test. [94]

\section{PRPP synthetase assay}

The assay of PRPP activity (Figure 4.6) also rested on coupling to NADH consumption. $[90,95]$ The assay mixture $(1 \mathrm{~mL})$ was $100 \mathrm{mM}$ sodium phosphate buffer, $\mathrm{pH}$ 7.6, containing R5P•Na (5 mM), magnesium chloride (7 mM), NADH (0.2 mM), ATP (3 mM), PEP (1 mM), pyruvate kinase (3.3 $\mu \mathrm{L}, 2 \mathrm{U})$, myokinase (4 $\mu \mathrm{L}, 4 \mathrm{U})$, and lactate dehydrogenase $(3.3 \mu \mathrm{L}, 2 \mathrm{U})$. After a steady baseline was observed at $340 \mathrm{~nm}$, PRPP synthetase $(<1 \mu \mathrm{L}, 1 \mu \mathrm{g})$ was added, and the contents of the cuvette were mixed by inversion. The change in $A_{340}$ was monitored with time, and the rate of change and $\varepsilon_{340}$ of $\mathrm{NADH}\left(6220 \mathrm{M}^{-1} \cdot \mathrm{cm}^{-1}\right)$ was used to calculate the activity (Table 4.1)

\section{UPRTase assay}

The assay for UPRT activity (Figure 4.6) is based the change in $\Delta \varepsilon_{271}=2763 \mathrm{M}^{-1} \cdot \mathrm{cm}^{-1}$ for uracil and UMP (greater $\left.\varepsilon_{271}\right)$. [91] The assay mixture (1 $\mathrm{mL}$ ) was $50 \mathrm{mM}$ Tris $\bullet \mathrm{HCl}$ buffer, $\mathrm{pH} 7.5$, containing magnesium chloride $(5 \mathrm{mM})$, PRPP (1.5 mM), and uracil (0.1 mM). After a steady baseline was observed at 271 $\mathrm{nm}$, UPRTase $(<1 \mu \mathrm{L}, 1 \mu \mathrm{g})$ was added and $\Delta \mathrm{A}_{271}$ was monitored. 

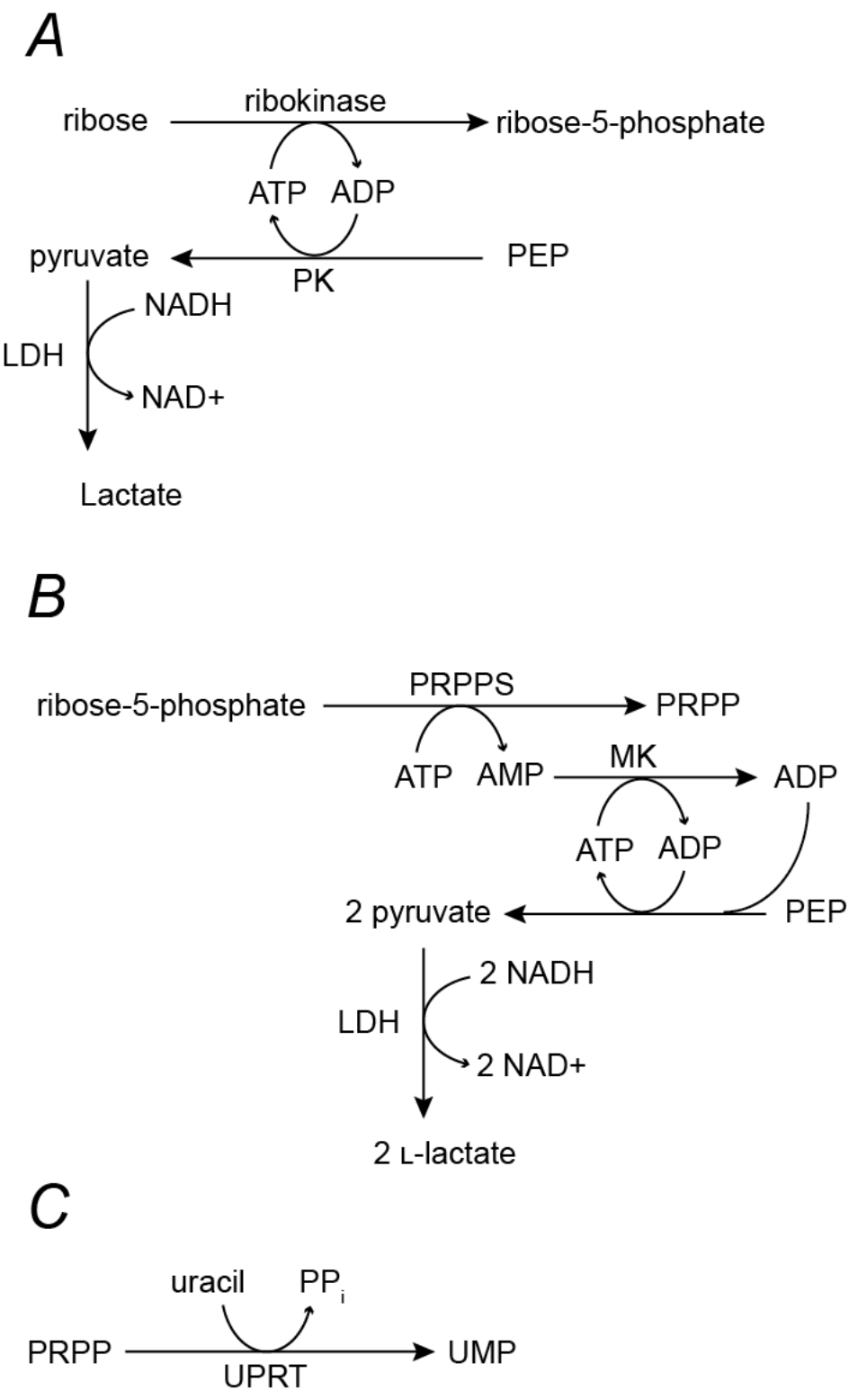

Figure 4.6: Schemes of the activity assays for the overexpressed enzymes. A, Ribokinase. B, PRPP synthetase. C, UPRTase. MK, myokinase; PK, pyruvate kinase; LDH, lactate dehydrogenase. 


\section{Synthesis of $\left[2^{\prime}-{ }^{2} \mathrm{H}\right]$ uridine triphosphate}

The published enzymatic synthesis of $\left[2^{\prime}-{ }^{2} \mathrm{H}\right]$ UTP $[91,92]$ was adapted to a smaller scale $(400 \mu \mathrm{mol})$. In a $50 \mathrm{ml}$ tube, $2^{\prime}-\left[{ }^{2} \mathrm{H}\right] \mathrm{D}$-Ribose $(60.7 \mathrm{mg}, 400 \mu \mathrm{mol})$ and uracil $(44.8 \mathrm{mg}, 400 \mu \mathrm{mol})$ were dissolved in synthesis buffer $(50 \mathrm{~mL})$, which is 50 mM potassium phosphate buffer, $\mathrm{pH} 7.5$, containing DTT (20 mM), kanamycin $(0.1$ $\mathrm{mM})$, ATP $(0.5 \mathrm{mM})$, ampicillin $(5 \mathrm{mM})$, magnesium chloride $(10 \mathrm{mM})$, and PEP (40 mM). The synthesis was initiated by the addition of ribokinase (50 U), PRPP synthetase (50 U), UPRTase (2 $\mathrm{U})$, nucleoside monophosphate kinase $(2 \mathrm{U})$, myokinase (37.5 $\mathrm{U})$, and pyruvate kinase (75 $\mathrm{U})$. [96] The reaction was monitored both by ${ }^{31} \mathrm{P}$ NMR and an assay of pyruvate formation. [91, 92] After $108 \mathrm{~h}$, no further increase in the amount of $2^{\prime}-\left[{ }^{2} \mathrm{H}\right]$ UTP was detected by ${ }^{31} \mathrm{P}$ NMR, and the reaction was judged to be essentially complete $(>90 \%)$ by pyruvate production. The reaction mixture was filtered through an Amicon DIAFLO YM-10 membrane $(10,000 \mathrm{MWCO})$ to remove enzymes, and activated charcoal $(2 \mathrm{~g})$ was added to the reaction mixture $(\sim 48 \mathrm{~mL})$ to adsorb UMP. After nutation for 15 min at $4{ }^{\circ} \mathrm{C}$, the charcoal was pelleted by centrifugation $(8000 \mathrm{~g}, 15 \mathrm{~min})$. After ensuring that the bulk of $\left[2^{\prime}-{ }^{2} \mathrm{H}\right]$ UTP (and ATP) was adsorbed to charcoal by measuring the absorbance of supernatant at $A_{260}$, the supernatant was discarded. The charcoal was washed successively with ice-cold water $(20 \mathrm{~mL})$ and aqueous ethanol (20 $\mathrm{mL} ; 2.5 \%, \mathrm{v} / \mathrm{v})$ containing ammonium hydroxide $(0.5 \%, \mathrm{v} / \mathrm{v})$. Finally, the charcoalbound $\left[2^{\prime}-{ }^{2} \mathrm{H}\right]$ UTP along with other "sticky" reaction components (primarily PEP

and ATP) were eluted twice with aqueous ethanol ( $30 \mathrm{~mL} ; 50 \% \mathrm{v} / \mathrm{v})$ containing ammonium hydroxide $(0.5 \% \mathrm{v} / \mathrm{v})$. [97]. The ethanolic elutions $(60 \mathrm{~mL})$ containing 
$2^{\prime}-\left[{ }^{2} H\right]$ UTP were combined and filtered through a Steriflip® vacuum filter unit to remove residual charcoal. The $\mathrm{pH}$ was adjusted to 6.5 using acetic acid $(1 \mathrm{M})$, and the solution was evaporated to dryness in vacuo, which yielded $\left[2^{\prime}-{ }^{2} \mathrm{H}\right]$ UTP as yellowish white powder ( $247 \mu \mathrm{mol}, 69 \%$ yield).

To remove PEP and ATP that co-eluted with $\left[2^{\prime}-{ }^{2} \mathrm{H}\right]$ UTP, the yellowish white powder was redissolved in $5 \mathrm{mM}$ triethylammonium acetate buffer $(1 \mathrm{~mL}), \mathrm{pH} 7.0$, and loaded onto a Bond Elut C8 SPE cartridge pre-equilibrated with the same buffer: elution was achieved with a step gradient of aqueous acetonitrile $(0-50 \%$, $v / v$ in $10 \%$ steps). 2 '-[ $\left.{ }^{2} \mathrm{H}\right]$ UTP eluted between $0-2.5 \%$ acetonitrile. The fractions containing $2^{\prime}-\left[{ }^{2} \mathrm{H}\right]$ UTP were detected by the characteristic absorbance of uridine at $260 \mathrm{~nm}$. These fractions were combined, and reduced in volume in vacuo using a rotary evaporator. Triethylammonium acetate was removed by the repeated addition and removal of water and isopropanol in vacuo with maintenance of $\mathrm{pH}$ $\sim 8.0$ by the addition of aqueous sodium hydroxide $(1 \mathrm{M})$. The $\left[2^{\prime}-{ }^{2} \mathrm{H}\right]$ UTP was recovered as a white powder and stored at $-80^{\circ} \mathrm{C}(165 \mu \mathrm{mol}, 46 \%$ yield $)$.

${ }^{1} \mathrm{H}$ NMR $\left(400 \mathrm{MHz}\right.$; $\left.\mathrm{D}_{2} \mathrm{O}\right)$ ס: $7.95\left(\mathrm{H}^{6}, 1 \mathrm{H}\right.$, doublet, $\left.J=8.4 \mathrm{~Hz}\right), 5.95\left(\mathrm{H}^{1} / \mathrm{H}^{6}\right.$,

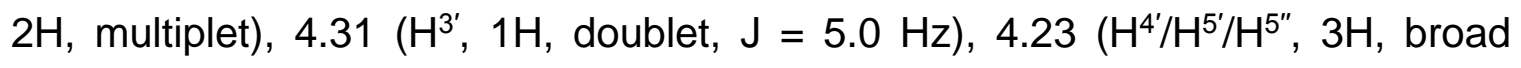
multiplet).

${ }^{31} \mathrm{P}$ NMR (162 MHz; D2O; $\left.1 \mathrm{H}\right) \mathrm{d}:-5.97 \mathrm{~Hz}(\alpha),-9.98 \mathrm{~Hz}(\mathrm{\gamma}),-21.20 \mathrm{~Hz}(\beta)$. In vitro transcription of RNA substrates

Unlabeled TSL. The partially double-stranded DNA template was prepared using commercially obtained oligonucleotides that had the following sequence: 5 'ATTATGCTGAGTGATATCGACACAAGCTAGGTGTC-3' (where underlining 
denotes the template sequence for TSL) and 5'-TAATACGACTCACTATAGC-3'. The template was annealed by incubating the strands together $(50 \mathrm{mM}$ each in a volume of $100 \mu \mathrm{L}$ ) for $5 \mathrm{~min}$ at $65^{\circ} \mathrm{C}$ followed by cooling on ice for $5 \mathrm{~min}$. This template was added to the transcription mixture $(10 \mathrm{~mL})$, which is $40 \mathrm{mM}$ Tris $\bullet \mathrm{HCl}$ buffer, $\mathrm{pH}$ 8.1, containing rNTPs (4 mM each), GMP (8 mM), magnesium chloride (25 mM), spermidine (1 mM), DTT (5 mM), Triton X-100 (0.01\%, v/v), Prime RNase Inhibitor (10 $\mu \mathrm{L}, 10 \mathrm{U})$, and inorganic pyrophosphatase $(5 \mu \mathrm{L}, 5 \mathrm{U})$. The in vitro transcription reaction was initiated by adding T7 RNA polymerase $(25 \mu \mathrm{L}$, $25000 \mathrm{U}$ ) and incubated for $9 \mathrm{~h}$ at $37^{\circ} \mathrm{C}$. [64] Urea-PAGE analysis was used to monitor the reaction progress. Periodically, an aliquot $(3 \mu \mathrm{L})$ of the reaction mixture was withdrawn and diluted with water (10 $\mu \mathrm{L}$ final volume); 2x RNA loading dye $(10 \mu \mathrm{L})$ was added, and the sample was then heated for 5 min at $94^{\circ} \mathrm{C}$, cooled on ice for $5 \mathrm{~min}$, and loaded on to a urea-PAGE gel (15\%, 7M urea). The transcription products were visualized with SYBR ${ }^{\circledR}$ Gold nucleic acid stain.

After analysis showed no further accumulation of TSL, TURBO ${ }^{\text {TM }}$ DNase (5 $\mu \mathrm{L}, 10 \mathrm{U}$ ) was added to the transcription reaction, which was incubated for an additional $15 \mathrm{~min}$ at $37^{\circ} \mathrm{C}$. Proteins were extracted from the reaction mixture with 1:1 phenol:chloroform. The crude RNA in the collected aqueous phase was precipitated with ethanol and pelleted by centrifugation $(8000 \mathrm{~g}, 30 \mathrm{~min})$. The pelleted RNA was washed with aqueous ethanol $(70 \%, v / v)$, air dried, and dissolved in $10 \mathrm{mM}$ Tris $\bullet \mathrm{HCl}$ buffer, $\mathrm{pH}$ 7.5, containing EDTA (1 mM).

The transcript of interest (18-mer) was purified from the crude mixture by urea-PAGE electrophoresis $(15 \%, 7 \mathrm{M}$ urea; $15 \mathrm{~cm} \times 15 \mathrm{~cm})$. The crude transcript 
$(1 \mathrm{~mL})$ was mixed with $2 x$ RNA dye $(1 \mathrm{~mL})$, heated for 5 min at $94{ }^{\circ} \mathrm{C}$, cooled on ice for $5 \mathrm{~min}$, and loaded onto the gel. After being developed at $165 \mathrm{~V}$ for $6 \mathrm{~h}$, the gel was removed, and the band of interest was located by UV-shadowing. RNA was extracted from the excised band either by electroelution using an Elutrap electrophoresis unit (GE Healthcare; Pittsburgh, PA) run at $200 \mathrm{~V}$ for $3 \mathrm{~h}$, or by the crush and soak method. [98] RNA was ethanol-precipitated, pelleted by centrifugation ( $8000 \mathrm{~g}, 30 \mathrm{~min}$ ), and redissolved in RNase free water. Purified TSL was divided into aliquots and stored at $-20^{\circ} \mathrm{C}$.

Labeled TSL. The labeled transcript was prepared identically to the unlabeled transcript, except that $\left[2^{\prime}-{ }^{2} \mathrm{H}\right]$ UTP $(4 \mathrm{mM})$ was substituted for UTP.

ASL. The in vitro transcription of ASL with UTP and $\left[2^{\prime}-{ }^{2} \mathrm{H}\right]$ UTP was identical to the synthesis of TSL except for the template, which was composed of 5'GCGGATTTTCAATCCGCTATAGTGAGTCGTATTA-3' (underlining indicates the complement to ASL) and 5'-TAATACGACTCACTATAGC-3'.

\section{Digestion of transcripts and MALDI-MS}

An aliquot of the RNA oligonucleotide $(10 \mu \mathrm{L}, 80-100 \mu \mathrm{M})$ was diluted into RNase-free water $(40 \mu \mathrm{L})$ to which RNase T1 $(2 \mu \mathrm{L}, 200 \mathrm{U})$ was added. After incubation for $1 \mathrm{~h}$ at $37^{\circ} \mathrm{C}$, alkaline phosphatase $(5 \mu \mathrm{L}, 5 \mathrm{U})$ was added to the digestion mixture, which was incubated for an additional $3 \mathrm{~h}$ at $37^{\circ} \mathrm{C}$. An aliquot (3 $\mu \mathrm{L})$ of the digest was mixed with 3-HPA matrix solution $(3 \mu \mathrm{L})$, which was 3hydroxypicolinic acid (3-HPA; Fluka, Milwaukee, Wl; $10 \mathrm{mg} / \mathrm{ml}$ ) in $50 \%$ aqueous acetonitrile. The sample was spotted on a MALDI plate, air dried, and analyzed on a Voyager DE-Pro MALDI-TOF instrument or an API 4700 MALDI-TOF Mass 
spectrophotometer (PE Biosystems, Foster City, CA). Spectra were acquired and analyzed as described in Chapters 2 and 3.

\section{Kinetic assays}

The enzymes TruB and RluA were overexpressed, purified, and assayed using published protocols. [30,64] For TruB, the standard reaction buffer was 50 mM HEPES buffer, $\mathrm{pH} 7.5$, containing ammonium chloride (100 mM), EDTA (1 $\mathrm{mM})$, and DTT (5 mM). [64] The reaction mixtures $(400-2600 \mu \mathrm{L})$ were standard reaction buffer containing TSL $(1-10 \mu \mathrm{M})$. After pre-incubation for 3 min at $37^{\circ} \mathrm{C}$, reactions were initiated by the addition of a small volume $(<2 \mu \mathrm{L}$ ) of TruB (to 10 $\mathrm{nM})$. Aliquots $(75-650 \mu \mathrm{L})$ were removed at various time intervals and quenched into pre-heated $\left(100^{\circ} \mathrm{C}\right)$ tube containing $10 \times \mathrm{S} 1$ nuclease digestion buffer $\left(1 / 10^{\text {th }}\right.$ the volume of aliquot), which is $300 \mathrm{mM}$ sodium acetate buffer, $\mathrm{pH} 4.6$, containing sodium chloride $(500 \mathrm{mM})$, zinc chloride $(100 \mathrm{mM})$, and glycerol $(50 \%, \mathrm{v} / \mathrm{v})$. After another $5 \mathrm{~min}$ in a boiling water bath, the tubes were cooled on ice for $5 \mathrm{~min}$. S1 nuclease $(0.5 \mu \mathrm{L}, 50 \mathrm{U})$ was added, and the mixture was incubated for $1 \mathrm{~h}$ at 37 ${ }^{\circ} \mathrm{C}$; the digest was then incubated for 5 min at $94{ }^{\circ} \mathrm{C}$ followed by incubation on ice for $5 \mathrm{~min}$. Another aliquot of $\mathrm{S} 1$ nuclease $(1 \mu \mathrm{L}, 100 \mathrm{U})$ and alkaline phosphatase $\left(3 \mu \mathrm{L}, 3 \mathrm{U}\right.$ ) were added, and the mixture was incubated for $3 \mathrm{~h}$ at $37^{\circ} \mathrm{C}$. The digest was then passed through a Corning Costar $^{\mathrm{TM}}$ spin filter $(0.22 \mu \mathrm{m})$, and analyzed over an SB-C18 analytical column connected to Beckman Coulter System Gold HPLC (Indianapolis, IN) equipped with a Model 168 programmable diode array detector module. 
For RluA, the previously reported assay procedure [30] was modified because, unlike commercially-obtained $\mathrm{ASL}^{\cup}$ (a 17-mer), the in vitro transcribed $\mathrm{ASL}^{\cup}$ (an 18-mer) was not readily separable from $\mathrm{ASL}^{\Psi}$. To quantify $\Psi$, the 18-mer ASL was digested to its component nucleosides and analyzed by HPLC. The assay mixtures (450-2400 $\mu \mathrm{L})$ were standard reaction buffer containing ASL (1-10 $\mu \mathrm{M})$. After pre-incubation for $3 \mathrm{~min}$ at $37^{\circ} \mathrm{C}$, reactions were initiated by the addition of a small volume $(<2 \mu \mathrm{L}$ ) of RluA (to $10 \mathrm{nM}$ ). Aliquots $(100-600 \mu \mathrm{L}$ ) were removed at various time intervals and quenched and analyzed as described above for TSL. 


\section{Results}

\section{Enzymes for the synthesis of $\left[2^{\prime}-{ }^{2} \mathrm{H}\right]$ UTP}

The plasmid encoding ribokinase ( $\mathrm{pET}-22 \mathrm{HT})$ showed poor levels of overexpression, and the activity of the overexpressed enzyme was low. DNA sequencing revealed insertions at both the ends of rbsK. To rectify these errors, Ndel and BamHI restriction sites were introduced on to the $5^{\prime}$ - and 3 '-ends of rbsK by PCR. This allowed both the restoration of the native gene by eliminating the insertions and a means to install rbsK in $\mathrm{pET}-15 \mathrm{~b}$. Use of this recombinant plasmid (pUL600) resulted in improved levels of expression for ribokinase (Figure 4.7). PRPP synthetase and UPRTase were expressed without incident. Assays revealed that all three enzymes had specific activities comparable to literature values (Table 4.1).

\section{Synthesis of $\left[2^{\prime}-{ }^{2} \mathrm{H}\right]$ UTP}

Because [2'-2H]UTP is commercially unavailable, it was synthesized by the enzymatic condensation of [2'-2H]D-ribose and uracil (Figure 4.9) according to the method of Williamson. [91, 92] The first step of this one pot synthesis involves phosphorylation of [2'-2H]D-ribose by ribokinase. PRPP synthetase then converts $\left[2^{\prime}-{ }^{2} \mathrm{H}\right] \mathrm{D}-$ ribose-5-phosphate into [2'-2H]PRPP which is converted into $\left[2^{\prime}-{ }^{2} \mathrm{H}\right] \mathrm{UMP}$ by UPRTase. [2'-2H]UDP results from phosphorylation at the expense of ATP by nucleoside monophosphate kinase, following which $\left[2^{\prime}-{ }^{2} \mathrm{H}\right] \mathrm{UTP}$ is generated by pyruvate kinase at the expense of PEP. 


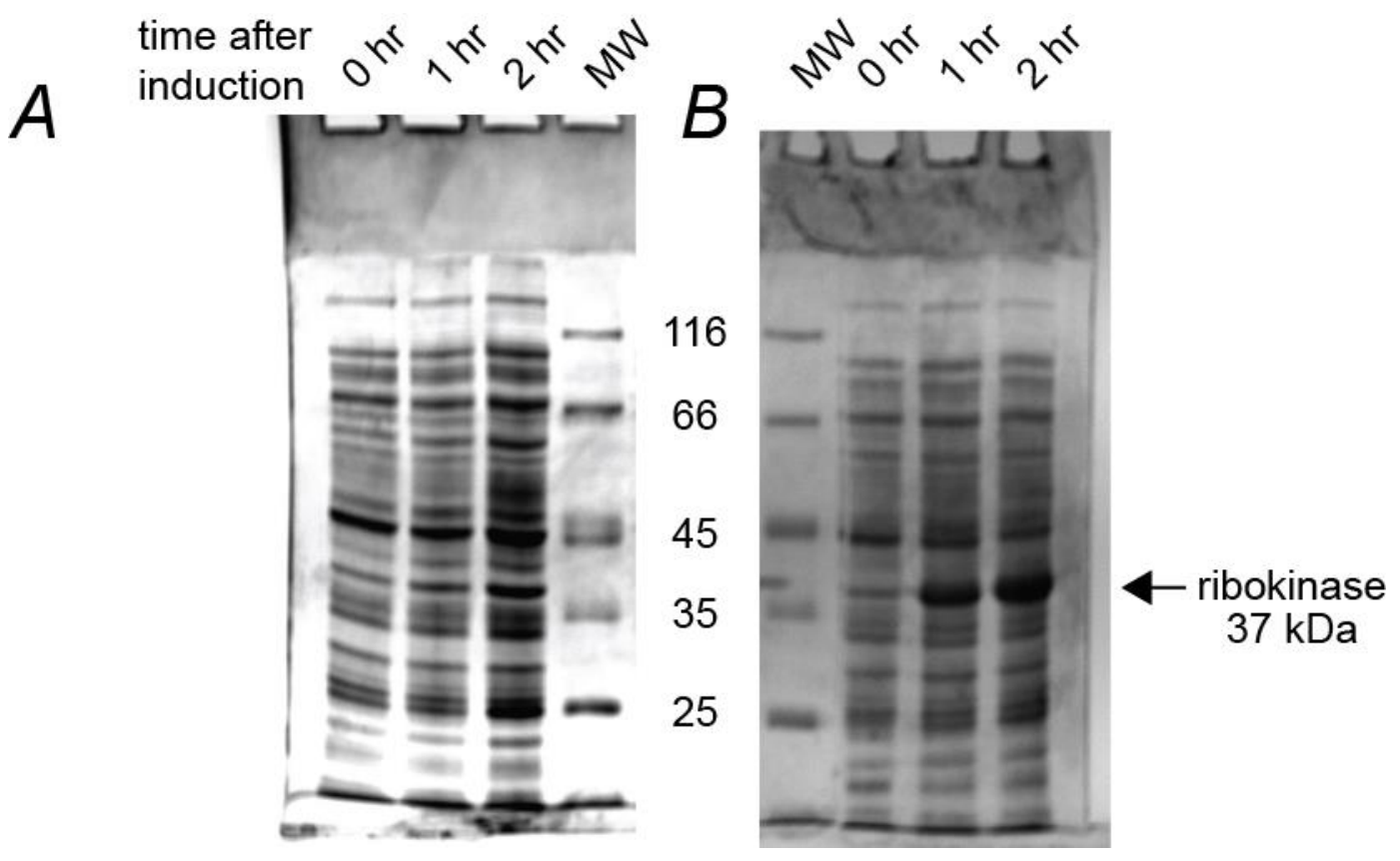

Figure 4.7: Ribokinase overexpression as monitored by SDS-PAGE. A, With pET22-HT. B, With pUL600. MW, EZ-Run ${ }^{\mathrm{TM}}$ protein markers (Fisher Scientific; Waltham, MA). 


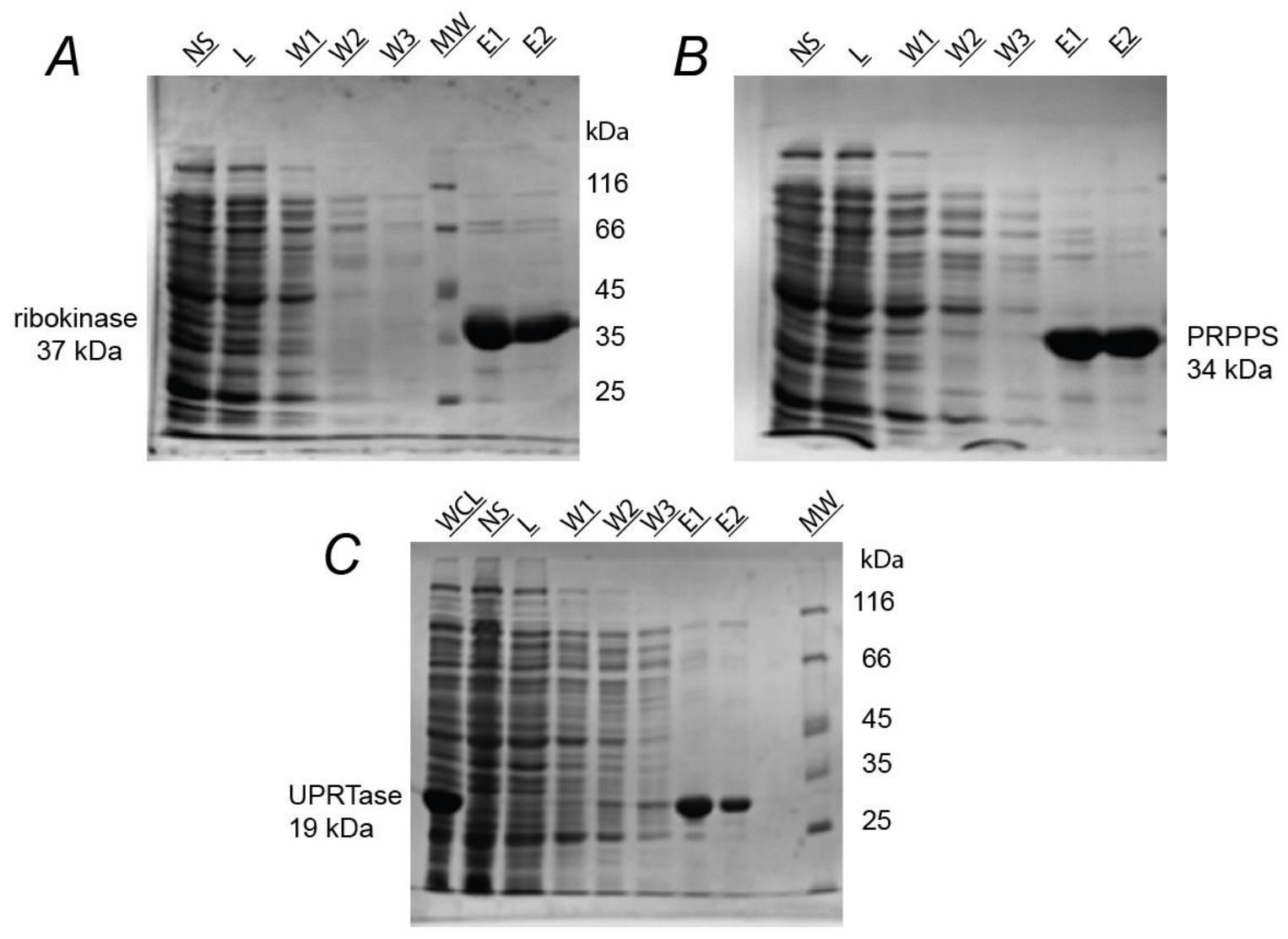

Figure 4.8: Purification of enzymes for the synthesis of UMP as monitored by SDS-PAGE. A, Ribokinase. B, PRPP synthetase. C, UPRTase. NS, supernatant from nutation of cell lysate with Ni-NTA resin; L, flow through from loading the Ni-NTA resin into a column $(0.7 \times 4.0 \mathrm{~cm})$; W1-3, washes $(4 \mathrm{~mL})$ with $50 \mathrm{mM}$ sodium phosphate buffer, $\mathrm{pH}$ 8.0, containing sodium chloride (300 mM) and imidazole (20 mM); E1-2, fractions $(4 \mathrm{~mL})$ from elution with $50 \mathrm{mM}$ sodium phosphate buffer, $\mathrm{pH}$ 8.0, containing sodium chloride (300 mM) and imidazole $(250 \mathrm{mM})$; MW, EZ-Run ${ }^{\mathrm{TM}}$ protein markers (Fisher Scientific; Waltham, MA). 
Table 4.1: Specific activities for ribokinase, PRPP synthetase, and UPRTase.

\begin{tabular}{cccc}
\hline & $\begin{array}{c}\text { specific activity } \\
\mu \mathrm{mol} \cdot \mathrm{min}^{-1} \cdot \mathrm{mg}^{-1}\end{array}$ & $\begin{array}{c}\text { reported } \\
\mu \mathrm{mol}^{\mathrm{s}} \cdot \mathrm{min}^{-1} \cdot \mathrm{mg}^{-1}\end{array}$ & $\begin{array}{c}\text { total activity } \\
\mu \mathrm{mol}^{\circ} \mathrm{min}^{-1}\end{array}$ \\
\hline ribokinase & $0.2 \pm 0.1^{\mathrm{a}}$ & $36.4 \pm 11.1$ & $22 \pm 12$ \\
& $99.9 \pm 12.8^{\mathrm{b}}$ & $11.4 \pm 0.8$ & $6300 \pm 150$ \\
$\begin{array}{c}\text { PRPP } \\
\text { synthetase }\end{array}$ & $9.1 \pm 1.3$ & $14.8 \pm 2.0$ & $122 \pm 16$ \\
UPRTase & $7.04 \pm 0.65$ & & $371 \pm 39$ \\
\hline
\end{tabular}

aOverexpressed from pET-22HT.

bOverexpressed from pUL600.

'From reference 95 
The overall synthesis minimally requires four equivalents of ATP, which was continuously generated in situ at the expense of PEP using pyruvate kinase and myokinase. To avoid buildup of ADP, the activity of myokinase was half that of pyruvate kinase.

After the synthesis of $\left[2^{\prime}-{ }^{2} \mathrm{H}\right]$ UTP was complete as judged by ${ }^{31} \mathrm{P}$ NMR and pyruvate assay, purification was achieved in three steps. The enzymes used in the synthesis were removed by ultrafiltration. More than $90 \%$ of PEP, inorganic phosphate, and pyruvate in the reaction mixture were removed by the adsorption of $\left[2^{\prime}-{ }^{2} \mathrm{H}\right]$ UTP and ATP onto charcoal, rinsing, and elution in aqueous ethanol. The $\left[2^{\prime}-{ }^{2} \mathrm{H}\right]$ UTP was freed of contaminating ATP and PEP by solid phase extraction over a Bond Elut C8 SPE cartridge. [2'-2H]UTP (167 $\mu \mathrm{mol}, 46 \%$ yield) was obtained at $>95 \%$ purity as judged by NMR spectroscopy (Figures $4.10,4.11$, and 4.12 ). 


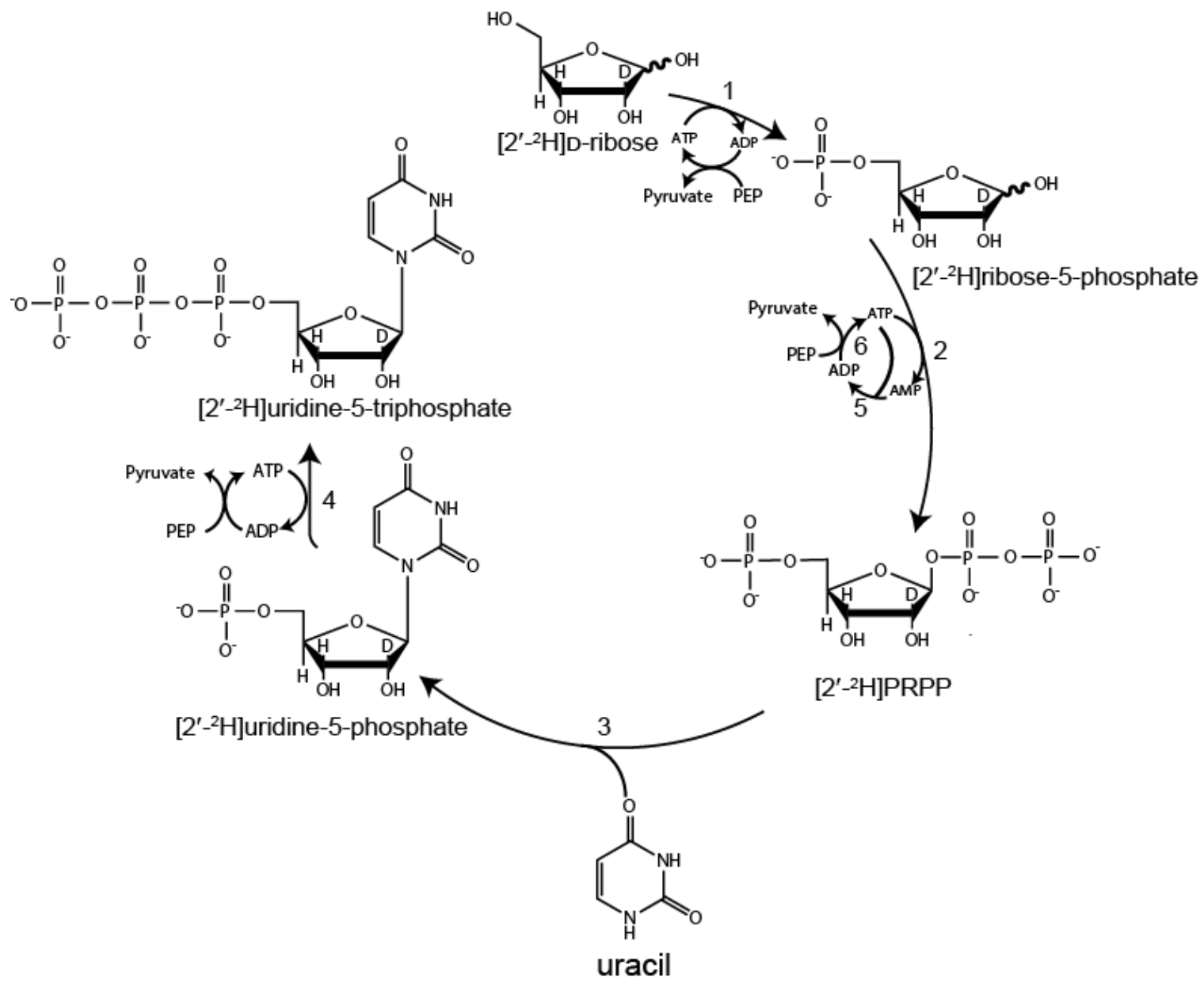

Figure 4.9: Enzymatic synthesis scheme for $\left[2{ }^{2}-{ }^{2} \mathrm{H}\right] \mathrm{UTP}$. ATP is generated in situ at the expense of PEP by pyruvate kinase and myokinase. 1, ribokinase; 2, PRPP synthetase; 3, UPRTase; 4, nucleoside monophosphate kinase; 5, myokinase; 6 , pyruvate kinase. 

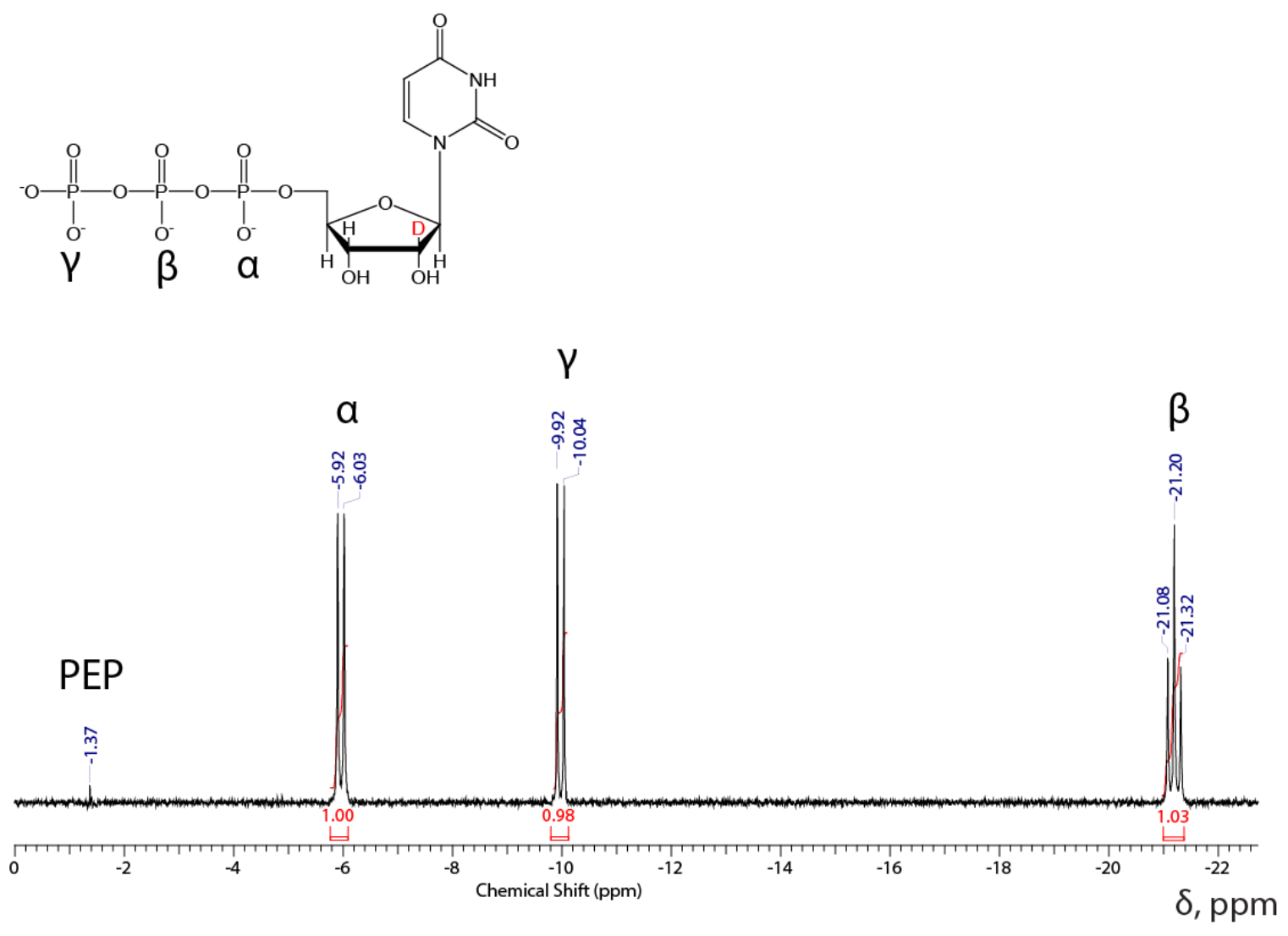

Figure 4.10: ${ }^{31} \mathrm{P}$ NMR spectrum of the purified $\left[2^{\prime}-{ }^{2} \mathrm{H}\right] \mathrm{UTP}$ showing the characteristic chemical shifts for $\alpha, \beta$, and $y$ phospho groups. 

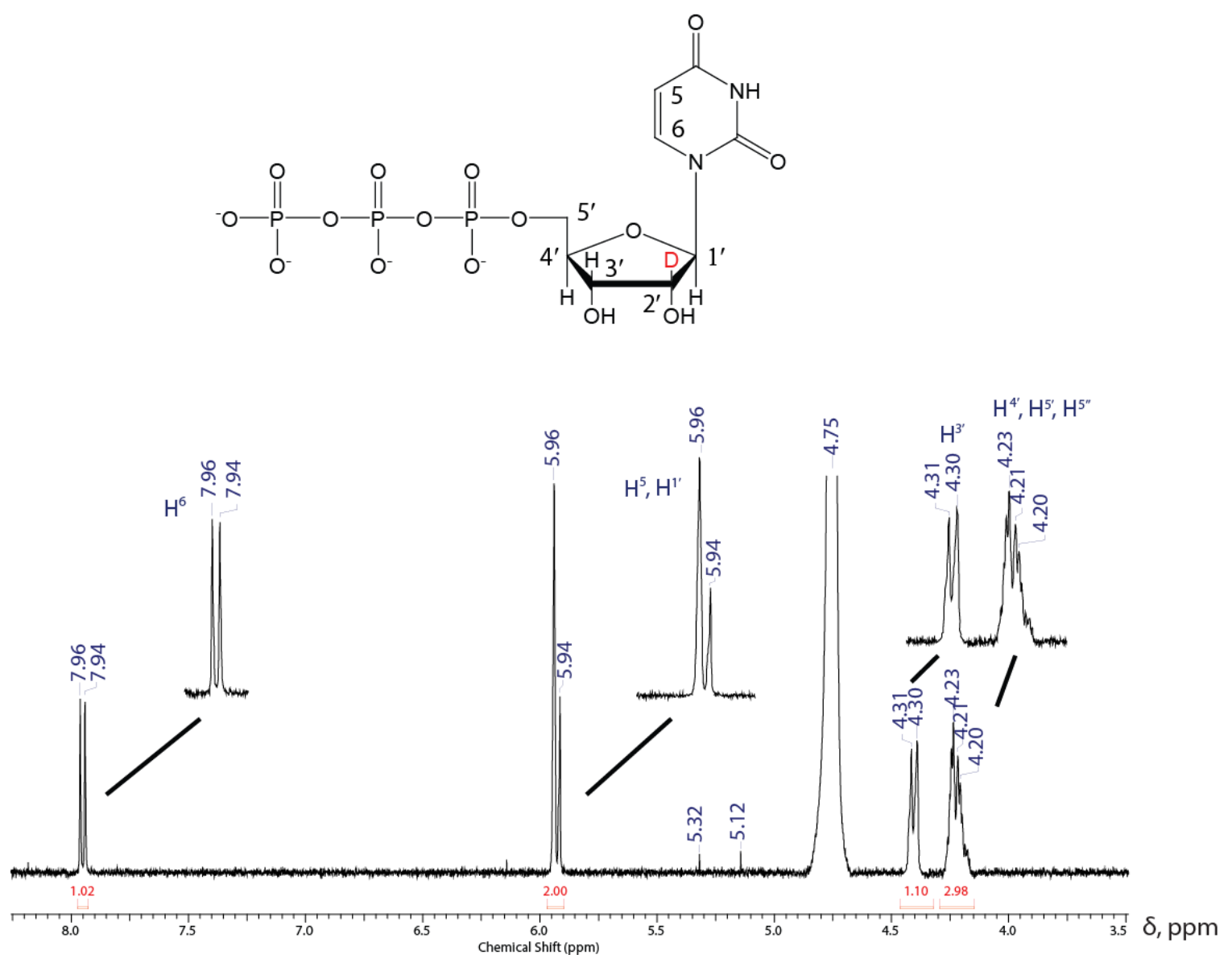

Figure 4.11: ${ }^{1} \mathrm{H}$ NMR spectrum of purified $\left[2^{\prime}-{ }^{2} \mathrm{H}\right] \mathrm{UTP}$. The "absence" of $\mathrm{H}^{2}$ is evident. 

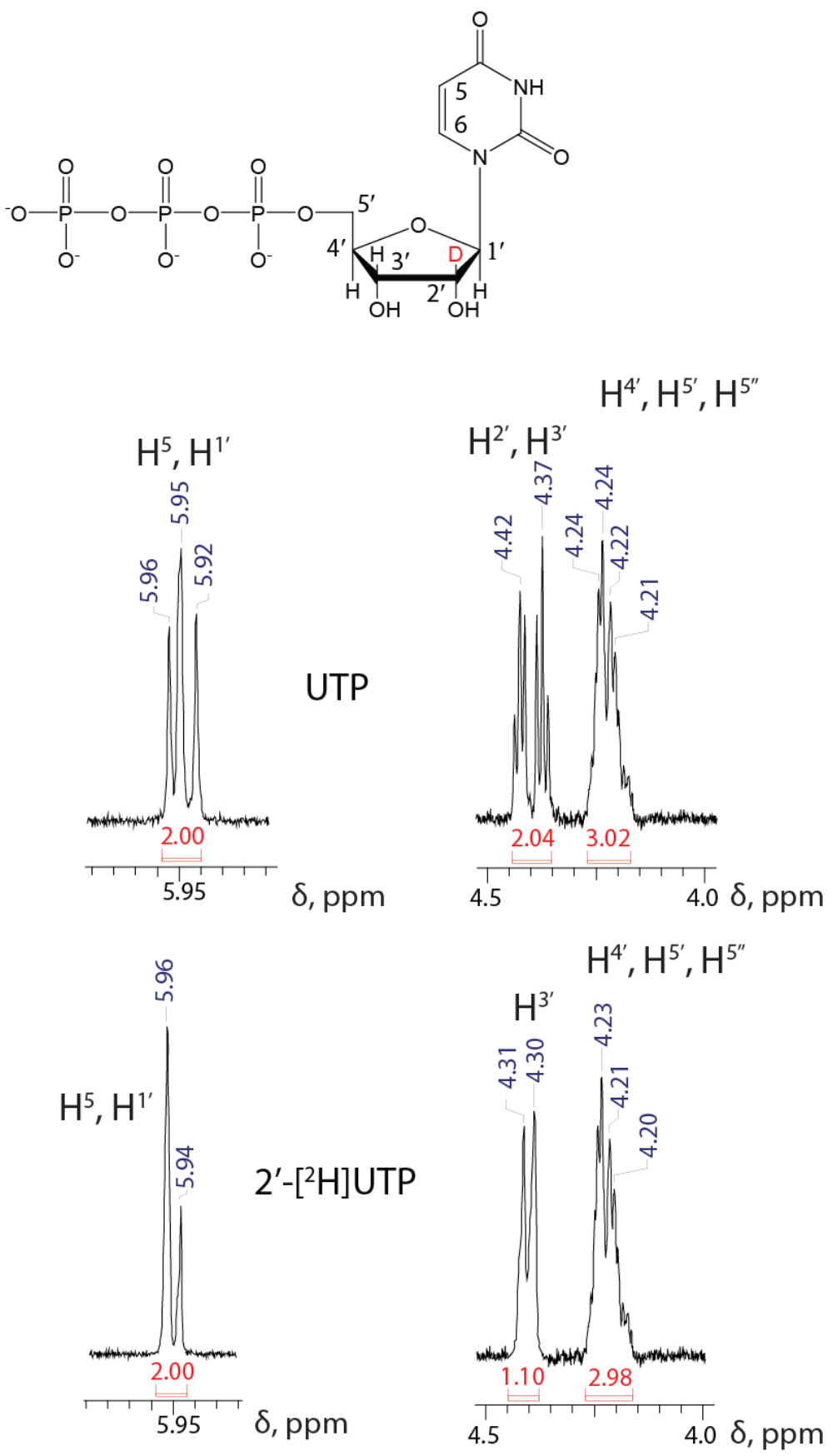

Figure 4.12: Comparison of the ${ }^{1} \mathrm{H}$ NMR spectra of $\left[2^{\prime}-{ }^{2} \mathrm{H}\right]$ UTP and

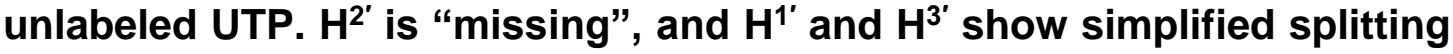
patterns. 


\section{In vitro transcription}

Unlabeled and labeled stem-loop RNA substrates for TruB and RluA were prepared by run-off in vitro transcription using T7 RNA polymerase. The template and rNTP concentrations and time were optimized because transcription efficiency is highly sensitive to them depending on the length of the RNA being transcribed. [99] The transcription of these short stem-loops required a higher concentration of DNA template $(0.5 \mu \mathrm{M})$ and a longer incubation $(9 \mathrm{~h})$ when compared to the transcription of full length tRNA. [64]

TSL. The original S. cerevisiae I-arm stem-loop tRNA ${ }^{\text {Phe }}$ (TSL) substrate is a 17-mer that starts with a 5'-Cytidine. For efficient transcription, T7 RNA polymerase requires $\mathrm{G}$ as the initial nucleotide. Therefore, two TSL transcripts of lengths 18 (5'-G added to canonical TSL) and a 19-mer (5'-GG added) were tested for in vitro transcription and obtained in comparable yields $(9 \mu \mathrm{mol} 18$-mer versus $11 \mu \mathrm{mol} 19$-mer). When these transcripts $(5 \mu \mathrm{M})$ were incubated with $E$. coli TruB $(0.5 \mu \mathrm{M})$ in standard reaction buffer for $1 \mathrm{~h}$ at $58{ }^{\circ} \mathrm{C}$, analysis of the digested nucleosides by reverse phase HPLC showed complete conversion for both transcripts, showing their competence as substrates. In aliquots withdrawn after 1 min, the $18-\operatorname{mer}(64.5 \%)$ showed greater conversion of $U$ to $\Psi$ than the $19-\mathrm{mer}$ (52.0\%), so the 18-mer RNA was chosen for large-scale transcription (10 mL).

Once trials determined optimal in vitro transcription conditions, UTP and [2'${ }^{2} \mathrm{H}$ ]UTP were used in separate transcription reactions to generate unlabeled and labeled 18-mer TSL (Figure 4.13), which will hereafter be termed TSL for simplicity. 
ASL. The anticodon-stem-loop from E. coli tRNA ${ }^{\text {Phe }}(\mathrm{ASL})$ starts with a string of four Gs (Figure 4.14, panel A), which in principle eliminates the need to alter the 5'-end. However, small scale transcription revealed in a "ladder" of transcription products rather than a single one (Figure 4.14, panel C). Literature review $[100,101]$ revealed that T7 RNA polymerase undergoes "slippage" when transcribing RNA containing a stretch of three or more Gs, which is the case with ASL. This issue was addressed by designing a DNA template that would instead transcribe ASL with a reversed C-G base pair at the second position (Figure 4.14, panel $B$ and $C)$. This change resulted in a single transcription product. UTP and $\left[2^{\prime}-{ }^{2} \mathrm{H}\right]$ UTP were used in separate large scale transcription reactions to afford labeled and unlabeled variant ASL, which will hereafter be termed ASL for simplicity (Figure 4.14).

\section{Sequence verification of transcripts}

The sequences of unlabeled and labeled TSL and ASL transcripts were verified by digestion with RNase $\mathrm{T} 1$ and analysis by MALDI-TOF mass spectroscopy. The digestion products containing $\left[2^{\prime}-{ }^{2} \mathrm{H}\right] \mathrm{U}$ showed a corresponding increase in the $\mathrm{m} / \mathrm{z}$ value when compared to their unlabeled counterparts (Figure 4.15 and 4.16$)$. 


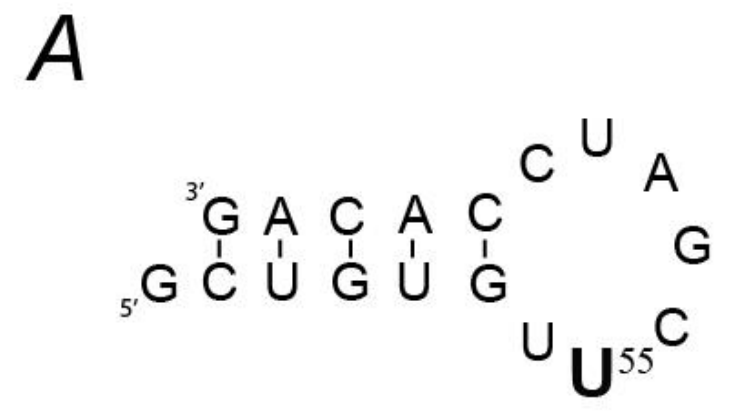

in vitro transcribed TSL (18-mer)
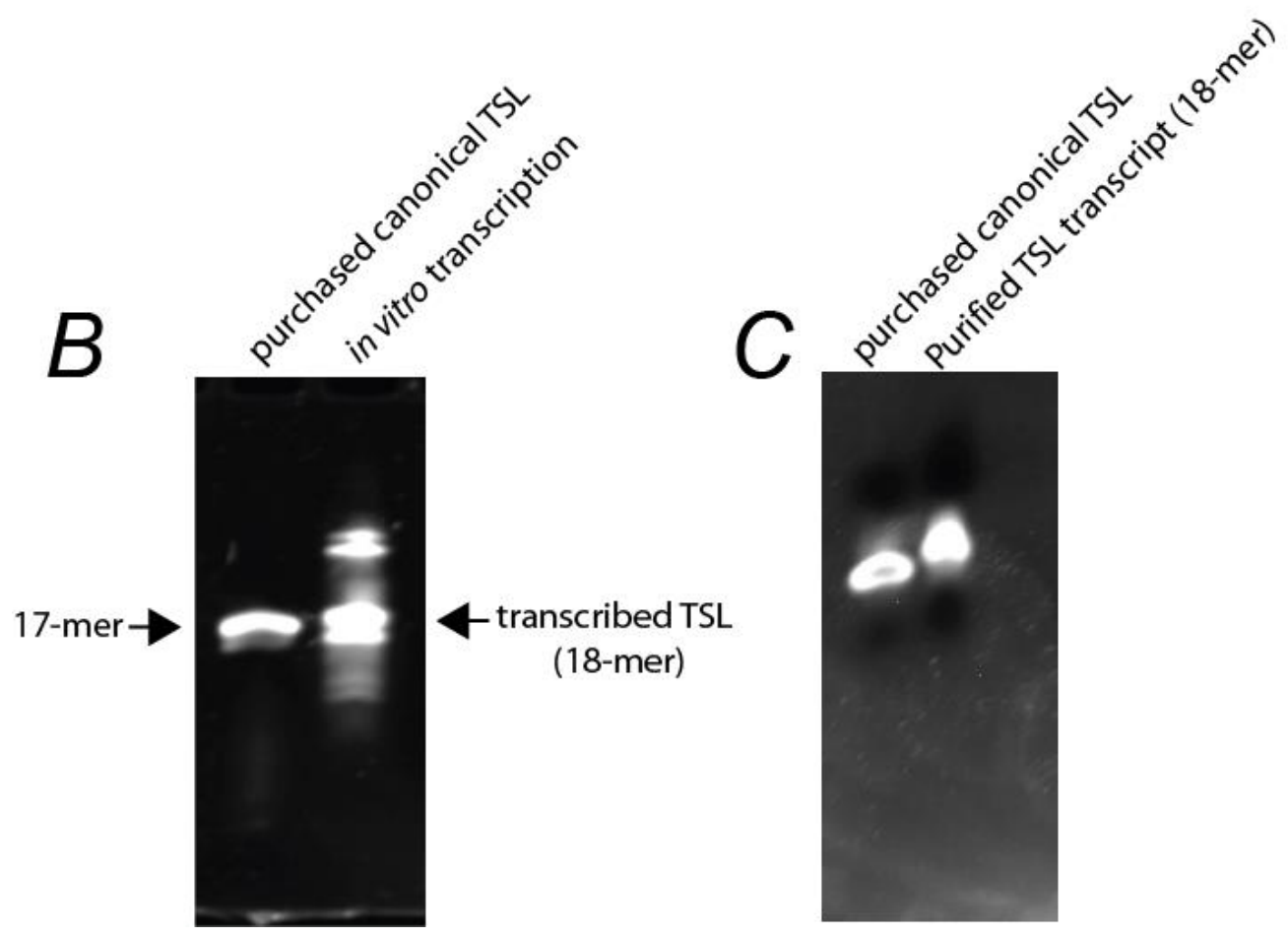

Figure 4.13: In vitro transcription results for TSL. A, Transcribed TSL (18mer). $B$, Urea-PAGE (15\%, $7 \mathrm{M}$ urea) analysis of the crude in vitro transcript. C, Urea-PAGE (15\%, 7M urea) analysis of purified labeled TSL. 
$A$

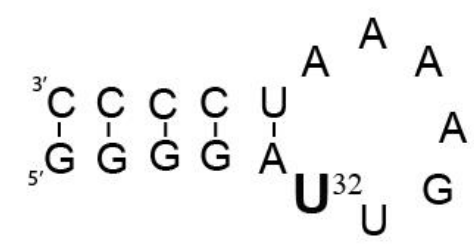

canonical ASL
$B$

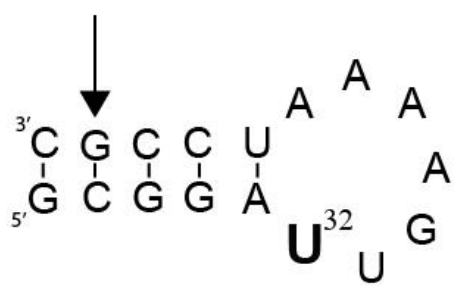

in vitro transcribed ASL

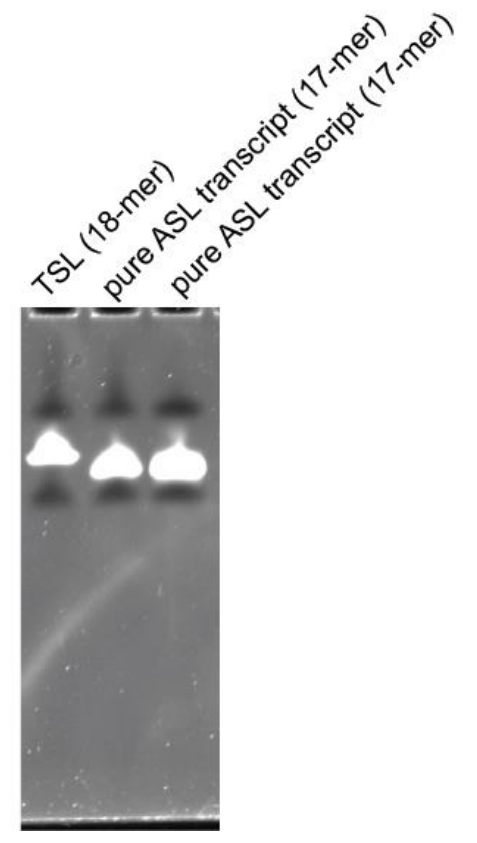

Figure 4.14: In vitro transcription of ASL. A, Canonical ASL used in previous studies. [4] B, In vitro transcribed ASL (the arrow denotes the reversed base pair). C, Urea-PAGE $(15 \%, 7 \mathrm{M}$ urea) analysis of the in vitro transcription of canonical ASL. D, Urea-PAGE (15\%, 7M urea) analysis of the in vitro transcription of the variant ASL. E, Urea-PAGE (15\%, $7 \mathrm{M}$ urea) analysis of the purified labeled ASL. 


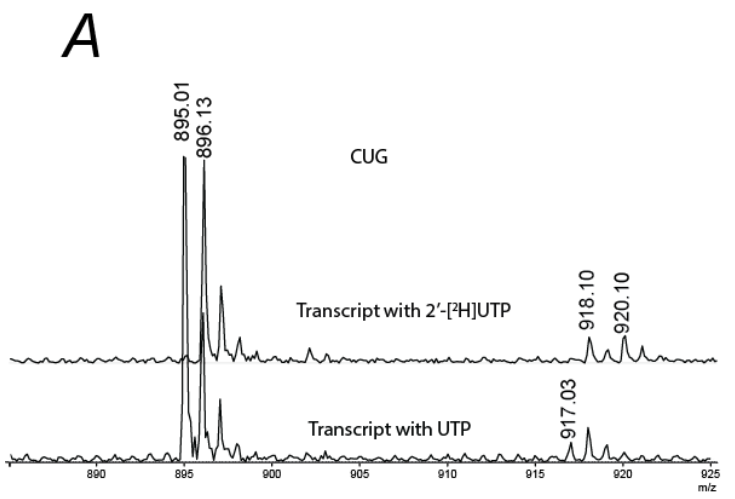

$B$
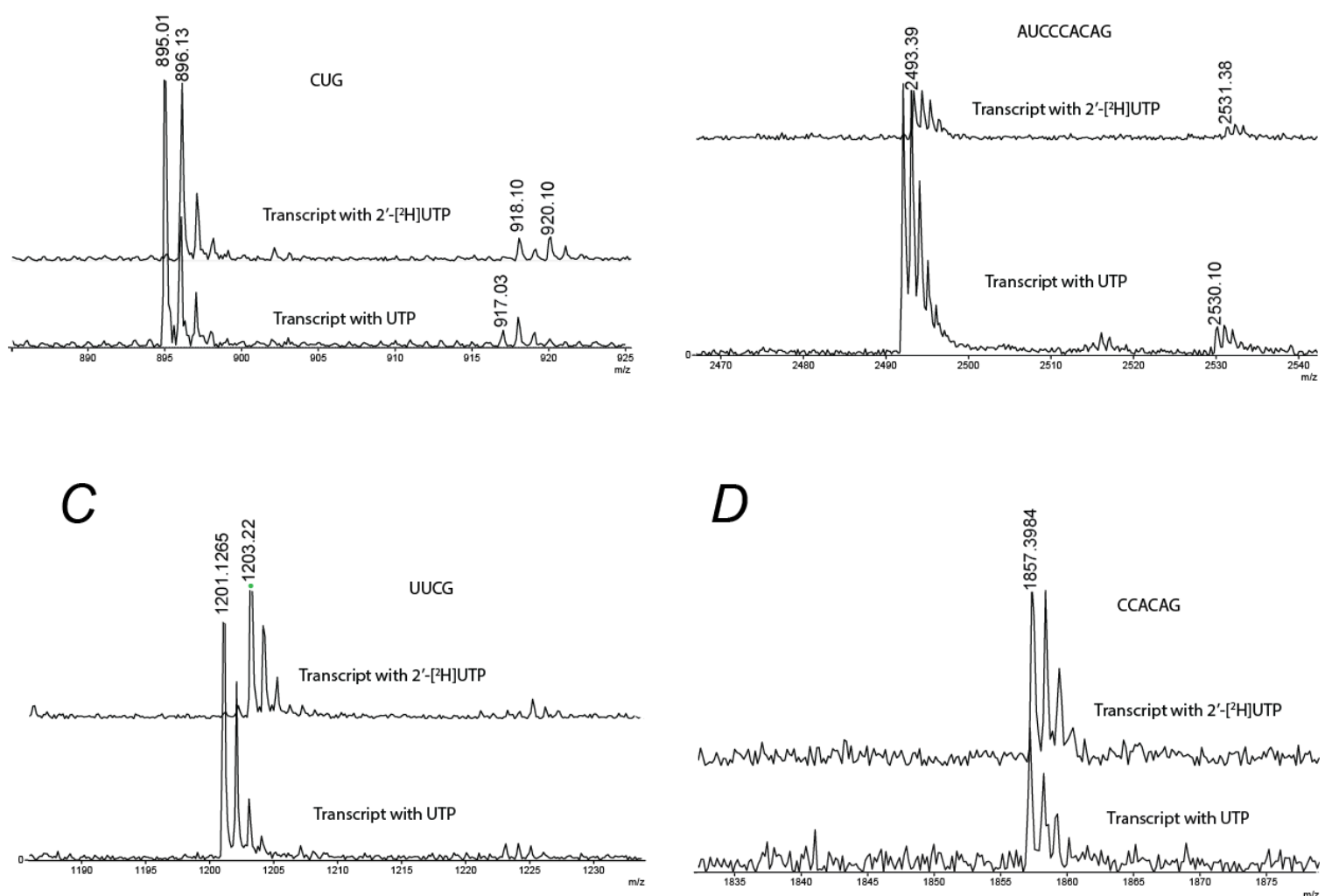

Figure 4.15: Partial MALDI-TOF mass spectra for the RNase T1 digests of unlabeled (lower traces) and labeled (upper traces) TSL. A, CUG (895.16 $\mathrm{m} / \mathrm{z}_{\text {pred }}$ ). B, AUCCACAG (2492.40 $\left.\mathrm{m} / \mathrm{z}_{\text {pred }}\right)$. C, UU ${ }^{55} \mathrm{CG}\left(1201.19 \mathrm{~m} / \mathrm{z}_{\text {pred }}\right) . \mathrm{D}$, CCACAG (1857.33 $\left.\mathrm{m} / \mathrm{z}_{\text {pred }}\right)$. 

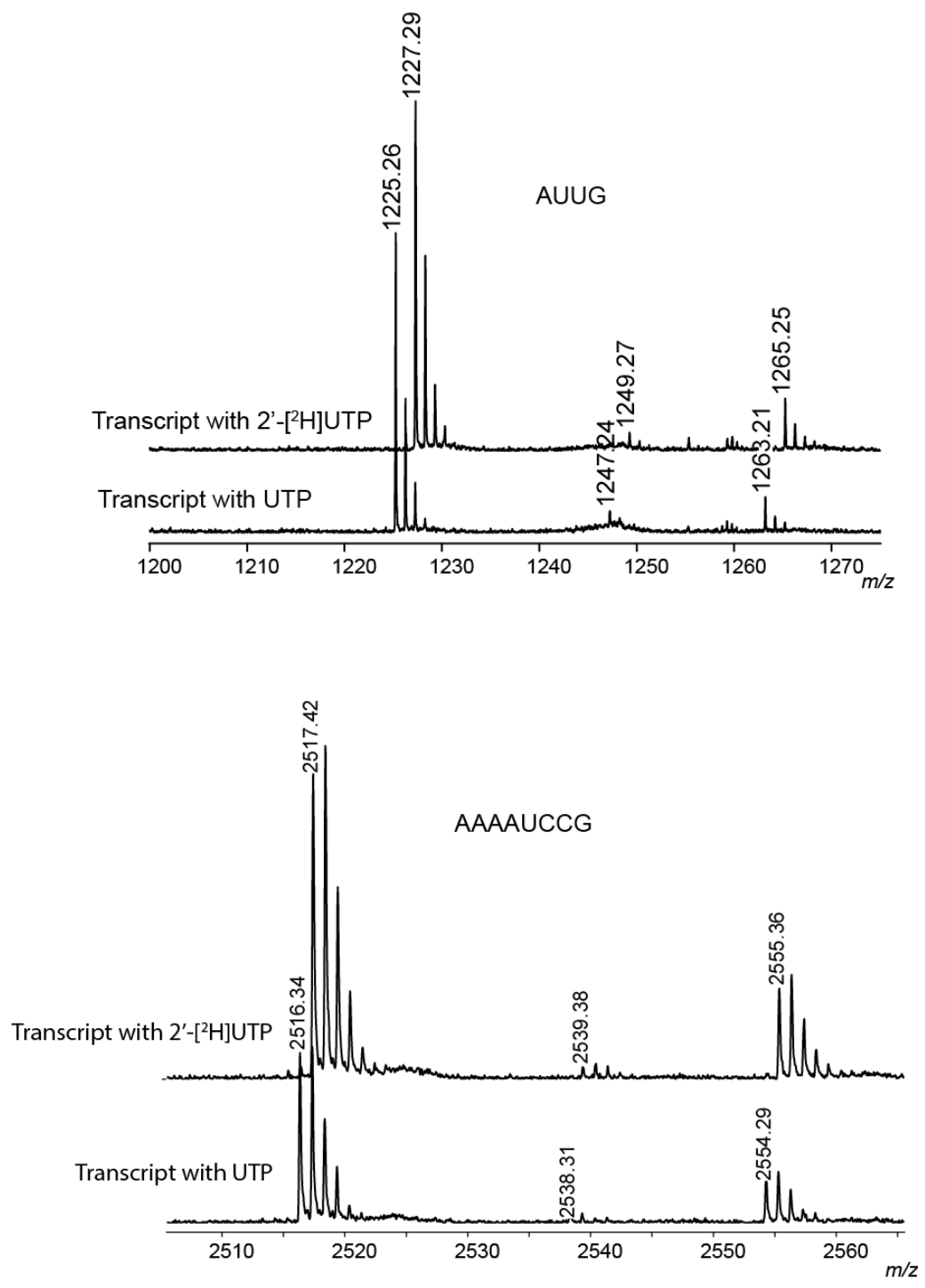

Figure 4.16: Partial MALDI-TOF mass spectra for the RNase T1 digests of unlabeled (lower traces) and labeled (upper traces) ASL. A, AU ${ }^{32} \mathrm{UG}$ (1225.26 $\left.\mathrm{m} / \mathrm{z}_{\text {pred }}\right)$. B, AAAAUCCG $\left(2516.42 \mathrm{~m} / \mathrm{z}_{\text {pred }}\right)$. 


\section{Kinetic assays}

TruB was assayed under conditions used previously. [64] The efficacy of the quench methodology was verified by analyzing time points for each assay immediately after addition of TruB to initiate the reaction. Because intact TSL ${ }^{U}$ did not separate from intact $\mathrm{TSL}^{\psi}$, the product RNA was digested to individual nucleosides to quantify $\Psi$ formation. The assays for the labeled and unlabeled substrates were performed at variable substrate concentrations as described in the Experimental section. The data was then fit to Briggs-Haldane equation (Figure 4.17) to determine the $k_{\text {cat }}$ and $K_{m}$ values, which revealed significant ${ }^{2} \mathrm{KIEs}$ (Table 4.2) on both $V_{\max }\left({ }^{2} V_{\max }=2.54\right)$ and $K_{m}\left({ }^{2}\left(V_{\max } / K_{m}\right)=3.58\right)$.

The assay for RluA was similar to that of TruB. The reaction quench methodology and the reverse phase HPLC-based quantification of $\mathrm{ASL}^{\Psi}$ were different from those previously reported [30] because the in vitro transcribed $\mathrm{ASL}^{U}$ failed to separate from the intact $\mathrm{ASL}^{\Psi}$. The assays for the labeled and unlabeled substrates were performed at different substrate concentrations and the initial velocity data was then fit to the Briggs-Haldane equation (Figure 4.18). The

determined $k_{\text {cat }}$ and $K_{m}$ values revealed a ${ }^{2} \mathrm{KIE}$ (Table 4.2) on both $V_{\max }\left({ }^{2} V_{\max }=\right.$ $1.79)$ and $K_{\mathrm{m}}\left({ }^{2}\left(V_{\max } / K_{\mathrm{m}}\right)=2.17\right)$. 


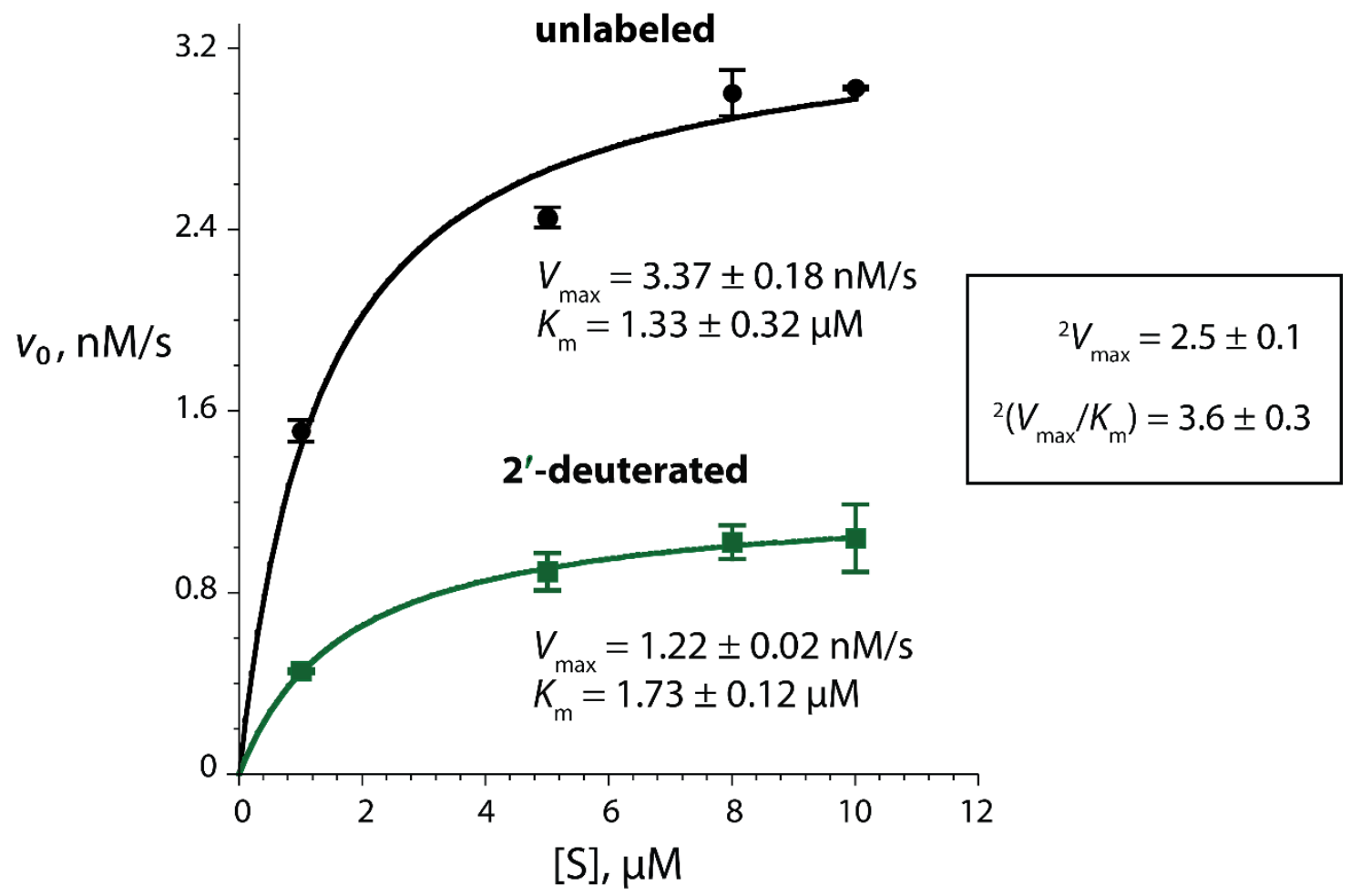

Figure 4.17: Briggs-Haldane fit $\left(R^{2}=0.99\right)$ for the kinetics of TruB with TSL containing $\mathrm{U}(\bullet)$ or $\left[2^{\prime}-{ }^{2} \mathrm{H}\right] \mathrm{U}(\square)$. 


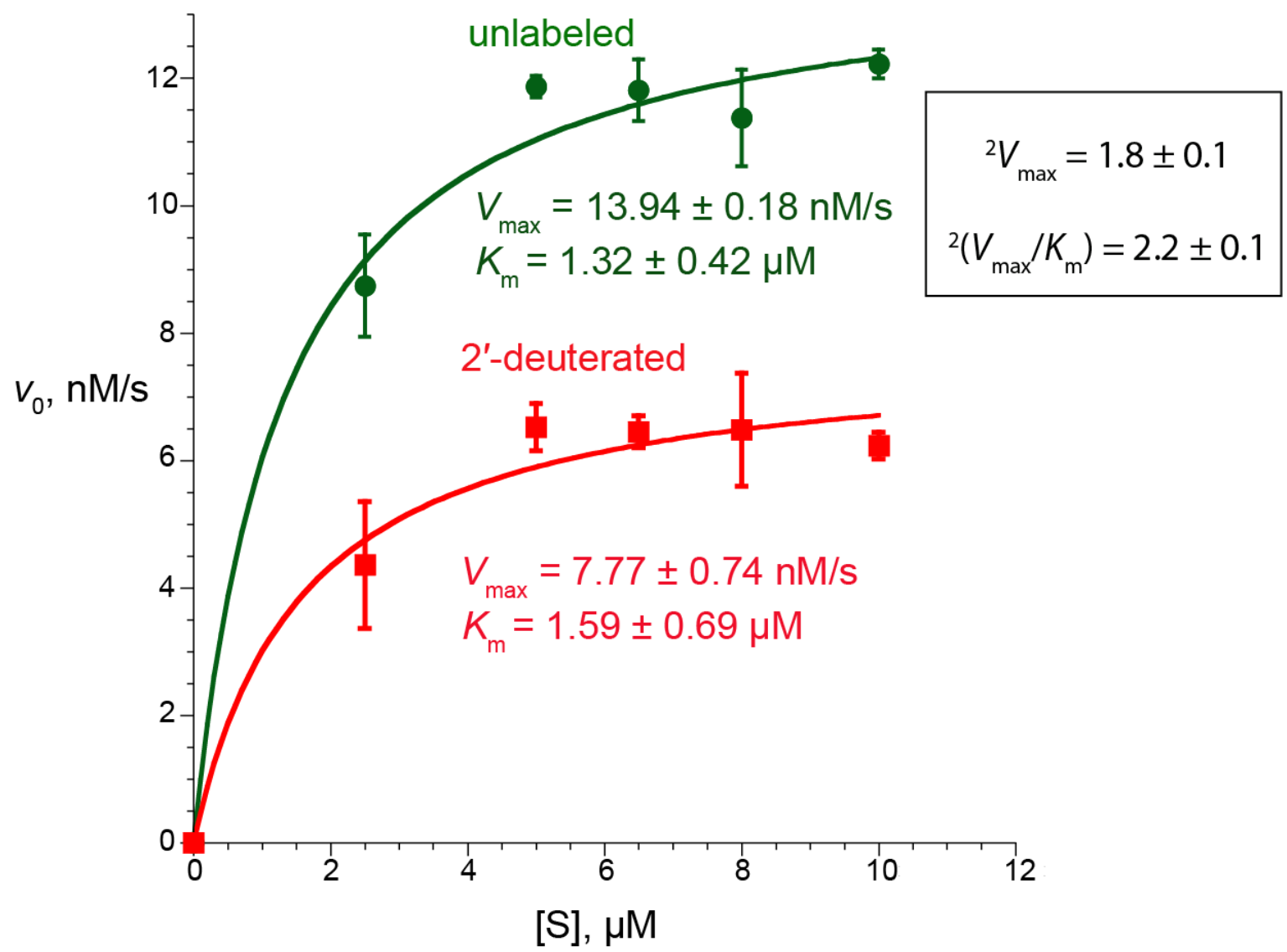

Figure 4.18: Briggs-Haldane fit $\left(R^{2}=0.98\right)$ for the kinetics of RluA with ASL containing $\mathrm{U}(\bullet)$ or $\left[2^{\prime}-{ }^{2} \mathrm{H}\right] \mathrm{U}(\square)$. 
Table 4.2: Kinetic parameters for TruB and RluA with substrates containing $\mathrm{U}$ and $\left[2^{\prime}-{ }^{2} \mathrm{H}\right] \mathrm{U}$.

\begin{tabular}{ccccc}
\hline & $V_{\max }, \mathrm{nM} / \mathrm{s}$ & $K_{m}, \mu \mathrm{M}$ & ${ }^{2} V_{\max }$ & ${ }^{2}\left(V_{\max } / K_{\mathrm{m}}\right)$ \\
\hline & & TruB & \\
unlabeled TSL & $3.373 \pm 0.178$ & $1.334 \pm 0.318$ & $2.54 \pm 0.14$ & $3.58 \pm 0.27$ \\
labeled TSL & $1.223 \pm 0.020$ & $1.733 \pm 0.116$ & \\
& & RluA & \\
unlabeled ASL & $13.938 \pm 0.840$ & $1.318 \pm 0.412$ & $1.79 \pm 0.09$ & $2.17 \pm 0.09$ \\
labeled ASL & $7.773 \pm 0.745$ & $1.594 \pm 0.691$ & & \\
\hline
\end{tabular}




\section{Discussion}

To obtain definitive evidence for glycal intermediate formation during the conversion of $U$ to $\Psi,{ }^{2}$ KIE were measured. TSL and ASL were prepared by synthesizing $\left[2^{\prime}-{ }^{2} \mathrm{H}\right]$ UTP and incorporating it into RNA by in vitro transcription.

\section{Subcloning, overexpression and purification}

The overexpression of PRPP synthetase and UPRTase posed no problems. The specific activities of the purified enzymes were similar to literature values (Table 4.1). [95] However, the plasmid encoding ribokinase (pET-22HT) [91] afforded poor levels of overexpression of barely active enzyme (Table 4.1). DNA sequencing revealed an overhang after the stop codon and an inverted duplication towards the 5 '-end. These errors were rectified by introducing Ndel and BamHI restriction sites on to the immediate $5^{\prime}$ - and $3^{\prime}$-ends of rbsK to allow the precise placement of rbsK into $\mathrm{pET}-15 \mathrm{~b}$ to overexpress ribokinase with an $\mathrm{N}$ terminal His $\sigma^{\bullet}$ tag. The specific activity of the ribokinase thus obtained mildly exceeded the published value (Table 4.1). [95]

With the enzymes in hand, $\left[2^{\prime}-{ }^{2} \mathrm{H}\right]$ UTP was synthesized enzymatically (Figure 4.9). The synthesis requires at least 4 equivalents of ATP per equivalent of [ $\left.2^{\prime}-2 \mathrm{H}\right]$ UTP being formed, but high concentrations of ATP could not be directly used in the synthesis because released ADP would inhibit ribokinase and PRPP synthetase. These issues were addressed by in situ regeneration of ATP at the expense of PEP using pyruvate kinase and myokinase. The use of excess PEP

drove $\left[2^{\prime}-{ }^{2 H}\right]$ UTP synthesis to completion. However, the separation of the 
synthesized $\left[2^{\prime}-{ }^{2} \mathrm{H}\right]$ UTP from residual PEP and the by-product pyruvate presented a challenge. Charcoal adsorption proved a simple but effective means to separate $\left[2^{\prime}-{ }^{2} \mathrm{H}\right]$ UTP from PEP and pyruvate. Finally, $\left[2^{\prime}-{ }^{2} \mathrm{H}\right]$ UTP was separated from ATP by solid phase extraction over a $\mathrm{C}_{8}$ matrix.

\section{In vitro transcription}

Run-off transcription with T7 RNA polymerase is a convenient route to short oligonucleotides. [99, 102] The DNA sequence complementary to the required RNA product is placed downstream of the T7 promoter, which must be doublestranded for T7 RNA polymerase to bind. Efficient transcription requires $G$ as the first transcribed nucleotide (the +1 position). For the in vitro transcription of TSL (Figure 4.13, panel A), an extra $G$ was introduced on to the $5^{\prime}$-end for this purpose because the canonical TSL used in earlier studies of $\operatorname{TruB}[29,52]$ starts with a $C^{7}$ The canonical ASL used previously [30] begins with a run of four Gs, which sometimes causes the polymerase to "slip" back by one nucleotide, resulting in a "ladder" of transcripts. This phenomenon was apparent during the transcription of canonical ASL (Figure 4.14, panel A). Therefore, ASL was modified (Figure 4.14, panel B) by reversing the second base pair in the stem loop, which resulted in the sequence: 5'-GㅡGGAUUGAAAAUCCGC-3' (underlined regions represent the swapped nucleotides of the stem loop; Figure 4.13, panel B).

The concentration of rNTPs, template DNA, T7 RNA polymerase, and the length of the reaction incubation play an important role in obtaining good yields of

\footnotetext{
${ }^{7}$ It is the T-arm of S. cerevisiae tRNA ${ }^{\text {Phe }}$ and prepared by chemical synthesis rather than the in vitro transcription.
} 
transcripts. The slow step in transcription is initiation, which is directly affected by the concentration of rNTPs and T7 RNA polymerase. T7 RNA polymerase also tends to produce abortive transcripts 3-12 nucleotides in length before switching into its hardier processive mode, so there is a chance for the depletion of the rNTPs of nucleotides abundant in the initial part of the transcript. $[99,102]$ In the transcription of oligonucleotides shorter than 20-mers, a higher concentration of DNA template $(0.5-1 \mu \mathrm{M})$ and T7 RNA polymerase $(2500 \mathrm{U} / \mathrm{ml})$ yield better results $[99,102]$ because of the increase in the number of transcription initiation events. All of these considerations went into the optimization of conditions to maximize the yield of transcript with precious $\left[2^{\prime}-2 \mathrm{H}\right]$ UTP. The optimized conditions yielded sufficient TSL and ASL (both labeled and unlabeled) for the kinetic studies, and the sequence of the purified transcripts were verified by digestion with RNase T1 and analysis by MALDI-TOF mass spectrometry.

\section{Deuterium kinetic isotope effect studies}

A deuterium kinetic isotope effect $\left({ }^{2} \mathrm{KIE}\right)$ is the observed change in rate of a chemical reaction when one of the protons in the reactants is substituted with a (heavier) deuteron. Kinetic isotope effects arise from differences in zero-point energy levels for the isotopologues of interest in the ground and transition states (Figure 4.19). [88, 103] In the case of "a proton in flight" (a primary KIE), there is no zero-point energy difference at the transition state for proton transfer, so the lower zero-point energy level of deuterium versus protium translates in to a larger activation energy barrier for the heavier isotope and hence a decreased reaction rate. In this classical analysis, the zero point energy difference between protium 
and deuterium dictates a maximum value of 6.9 for a primary ${ }^{2} \mathrm{KIE}$, [88] but larger effects are seen when tunneling is involved because of the substantially short de Broglie wavelength of a deuteron $(0.45 \AA)$ versus a proton $(0.63 \AA)$. [88] A secondary effect arises when the deuterium remains bonded throughout the reaction to a carbon atom that undergoes a change in hybridization. The differences in the energy of bond bending modes between $s p^{2}$ and $s p^{3}$ centers impose a maximum theoretical value of 1.4 for a secondary ${ }^{2} \mathrm{KIE}$. [88]

For TruB with unlabeled TSL, $k_{\mathrm{cat}}=0.337 \pm 0.025 \mathrm{~s}^{-1}$ and $K_{\mathrm{m}}=1.334 \pm$ $0.318 \mu \mathrm{M}$, values in agreement with those reported previously $\left(k_{\text {cat }}=0.24 \mathrm{~s}^{-1}, K_{\mathrm{m}}\right.$ $=0.8 \mu \mathrm{M}) .[29]$ These observations suggest that the in vitro transcribed TSL serves as an excellent substrate for TruB despite the addition of an unpaired $5^{\prime}-\mathrm{G}$. The observed ${ }^{2} \mathrm{KIE}$ on $V_{\max }$ (2.54) and $V_{\max } / K_{\mathrm{m}}$ (3.58) indicate that deprotonation or reprotonation of $\mathrm{C2}^{\prime}$ (or both) is partially rate limiting and provide direct evidence for the operation of glycal mechanism (Figure 4.3) during the conversion of $U$ to $\Psi$.

RluA was chosen to test the generality of this finding with another family of $\Psi$ synthases. The $k_{\text {cat }}\left(0.558 \pm 0.010 \mathrm{~s}^{-1}\right)$ and $K_{\mathrm{m}}(1.32 \pm 0.42 \mu \mathrm{M})$ with the in vitro transcribed ASL with a reversed base pair in the stem were some 8-fold higher than those previously reported $\left(k_{\mathrm{cat}}=0.067 \pm 0.003 \mathrm{~s}^{-1}, K_{\mathrm{m}}=308 \pm 66 \mathrm{nM}\right)$ with canonical ASL, [30] indicating that this "new" ASL is an efficient substrate. Primary ${ }^{2} \mathrm{KIEs}$ were observed for $V_{\max }(1.79)$ and $V_{\max } / K_{\mathrm{m}}$ (2.17), again indicative of the operation of the glycal mechanism. These results with RluA cemented the observations with TruB, thereby providing unambiguous evidence for a glycal 
intermediate in the operation of two $\Psi$ synthase families and thus, by implication, for all $\Psi$ synthases. 


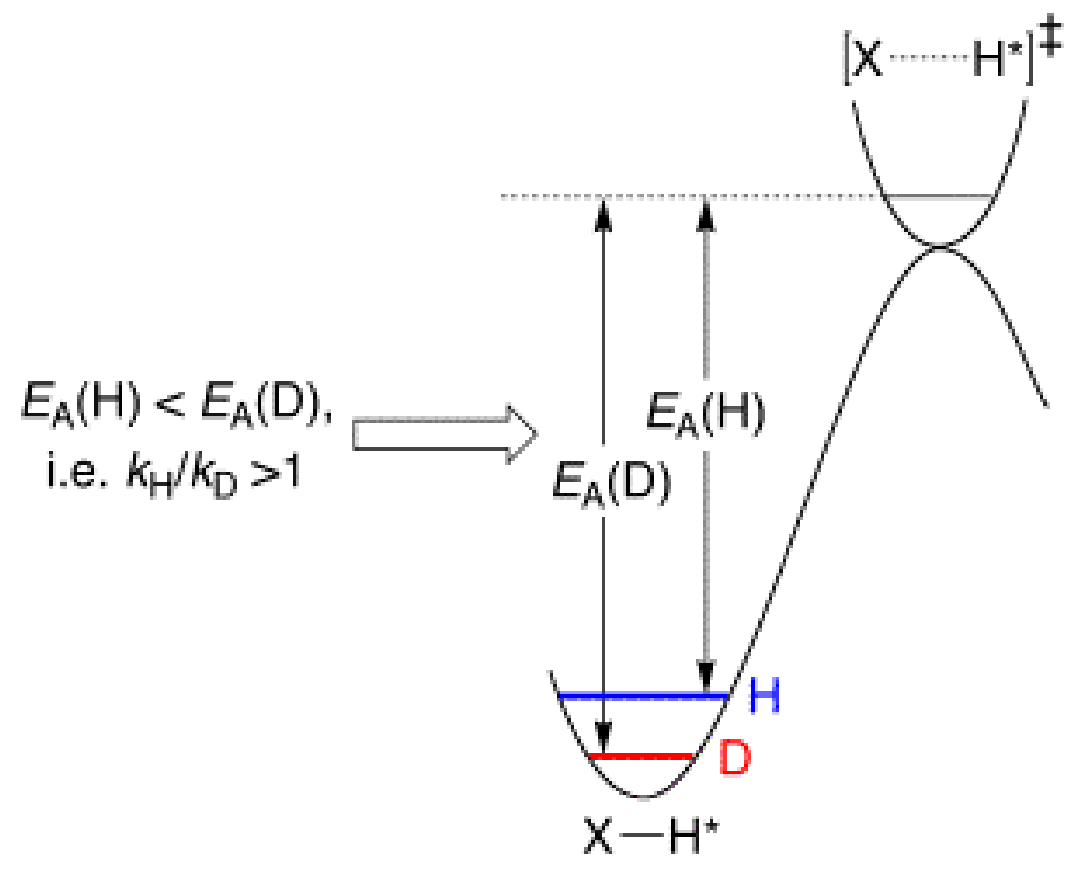

Figure 4.19: The primary ${ }^{2} \mathrm{KIE}$. Zero-point energy differences for a C-H bond compared to that of a C-D bond. Picture taken from reference 103. 
Table 4.3: The quantitation of nucleoside peaks from the HPLC traces for kinetic assays of TruB with unlabeled TSL. Relative integrations were adjusted with $\varepsilon_{260}$ for each nucleotide and normalized by assuming a value of 5.0 for $\mathrm{C}$.

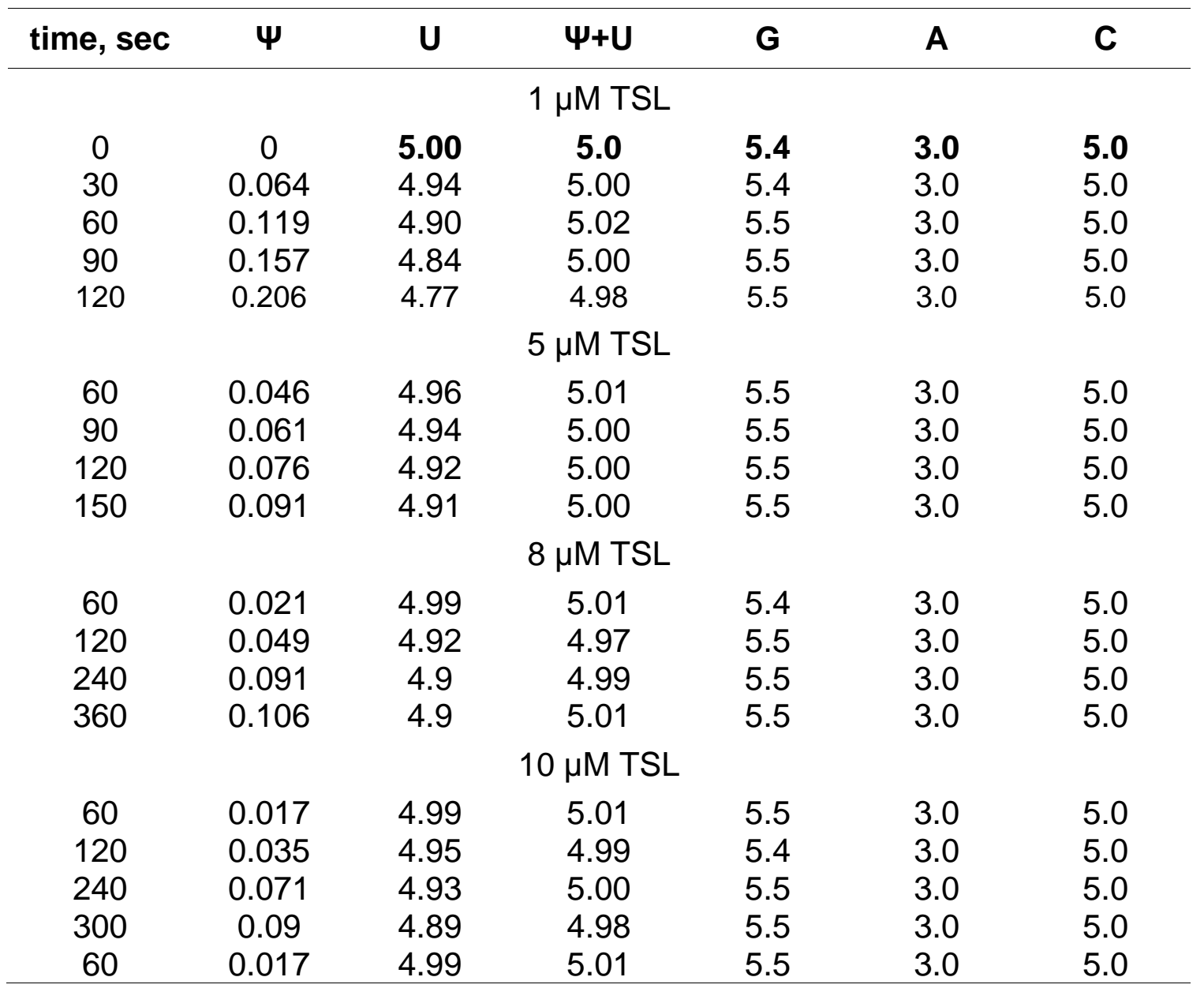


Table 4.4: The quantitation of nucleoside peaks from the HPLC traces for kinetic assays of TruB with labeled TSL. Relative integrations were adjusted with $\varepsilon_{260}$ for each nucleotide and normalized by assuming a value of 5.0 for $\mathrm{C}$.

\begin{tabular}{ccccccc}
\hline time, sec & $\boldsymbol{\Psi}$ & $\mathbf{U}$ & $\boldsymbol{\Psi + U}$ & $\mathbf{G}$ & $\mathbf{A}$ & $\mathbf{C}$ \\
\hline & & & $1 \mu \mathrm{M}$ TSL & & & \\
0 & 0 & $\mathbf{5 . 0 0}$ & $\mathbf{5 . 0}$ & $\mathbf{5 . 4}$ & $\mathbf{3 . 0}$ & $\mathbf{5 . 0}$ \\
60 & 0.072 & 4.88 & 4.95 & 5.4 & 3.0 & 5.0 \\
120 & 0.100 & 4.91 & 5.01 & 5.5 & 3.0 & 5.0 \\
180 & 0.135 & 4.85 & 4.99 & 5.5 & 3.1 & 5.0 \\
240 & 0.152 & 4.85 & 5.00 & 5.4 & 3.0 & 5.0 \\
& & & $5 \mu \mathrm{M} \mathrm{TSL}$ & & & \\
60 & 0.014 & 4.99 & 5.00 & 5.4 & 3.0 & 5.0 \\
120 & 0.024 & 4.98 & 5.00 & 5.4 & 3.0 & 5.0 \\
240 & 0.044 & 4.94 & 4.98 & 5.4 & 3.0 & 5.0 \\
300 & 0.061 & 4.95 & 5.01 & 5.3 & 3.0 & 5.0 \\
& & & $8 \mu \mathrm{M}$ TSL & & & \\
120 & 0.029 & 4.99 & 5.02 & 5.4 & 3.0 & 5.0 \\
180 & 0.043 & 4.97 & 5.01 & 5.4 & 3.0 & 5.0 \\
240 & 0.049 & 4.94 & 4.99 & 5.4 & 3.0 & 5.0 \\
360 & 0.063 & 4.94 & 5.00 & 5.4 & 3.0 & 5.0 \\
& & & $10 \mu \mathrm{M} \mathrm{TSL}$ & & & \\
120 & 0.032 & 4.97 & 5.00 & 5.5 & 3.0 & 5.0 \\
180 & 0.037 & 4.97 & 5.01 & 5.5 & 3.0 & 5.0 \\
240 & 0.046 & 4.95 & 5.00 & 5.5 & 3.0 & 5.0 \\
360 & 0.054 & 4.92 & 4.97 & 5.4 & 3.0 & 5.0 \\
120 & 0.032 & 4.97 & 5.00 & 5.5 & 3.0 & 5.0 \\
\hline
\end{tabular}


Table 4.5: The quantitation of nucleoside peaks from the HPLC traces for kinetic assays of RluA with unlabeled ASL. Relative integrations were adjusted with $\varepsilon_{260}$ for each nucleotide and normalized by assuming a value of 4.0 for $C$.

\begin{tabular}{|c|c|c|c|c|c|c|}
\hline time, sec & $\Psi$ & $\mathbf{U}$ & $\Psi+U$ & $\mathbf{G}$ & A & C \\
\hline \multicolumn{7}{|c|}{$2.5 \mu \mathrm{M}$ ASL } \\
\hline 0 & 0 & 3.0 & 3.0 & 5.4 & 5.0 & 4.0 \\
\hline 25 & 0.206 & 2.79 & 3.00 & 5.4 & 5.0 & 4.0 \\
\hline 45 & 0.275 & 2.73 & 3.01 & 5.5 & 4.9 & 4.0 \\
\hline 65 & 0.332 & 2.66 & 2.99 & 5.4 & 5.1 & 4.0 \\
\hline 85 & 0.405 & 2.49 & 2.90 & 5.4 & 5.1 & 4.0 \\
\hline \multicolumn{7}{|c|}{$5 \mu \mathrm{M}$ ASL } \\
\hline 25 & 0.138 & 2.86 & 3.00 & 5.5 & 5.1 & 4.0 \\
\hline 47 & 0.200 & 2.80 & 3.00 & 5.4 & 5.0 & 4.0 \\
\hline 66 & 0.239 & 2.76 & 3.00 & 5.4 & 5.0 & 4.0 \\
\hline 85 & 0.264 & 2.74 & 3.00 & 5.4 & 5.0 & 4.0 \\
\hline \multicolumn{7}{|c|}{$6.5 \mu \mathrm{M}$ ASL } \\
\hline 24 & 0.029 & 2.98 & 3.01 & 5.4 & 5.0 & 4.0 \\
\hline 41 & 0.043 & 2.97 & 3.01 & 5.5 & 4.9 & 4.0 \\
\hline 58 & 0.049 & 2.94 & 2.99 & 5.5 & 5.0 & 4.0 \\
\hline 80 & 0.063 & 2.94 & 3.00 & 5.5 & 5.0 & 4.0 \\
\hline \multicolumn{7}{|c|}{$8 \mu \mathrm{M}$ ASL } \\
\hline 23 & 0.112 & 2.89 & 3.00 & 5.4 & 5.0 & 4.0 \\
\hline 40 & 0.170 & 2.84 & 3.01 & 5.4 & 5.1 & 4.0 \\
\hline 60 & 0.238 & 2.81 & 3.05 & 5.4 & 4.9 & 4.0 \\
\hline 80 & 0.245 & 2.85 & 3.10 & 5.4 & 5.1 & 4.0 \\
\hline 23 & 0.112 & 2.89 & 3.00 & 5.4 & 5.0 & 4.0 \\
\hline \multicolumn{7}{|c|}{$10 \mu \mathrm{M}$ ASL } \\
\hline 28 & 0.109 & 2.9 & 3.01 & 5.4 & 5.0 & 4.0 \\
\hline 48 & 0.136 & 2.87 & 3.01 & 5.4 & 5.0 & 4.0 \\
\hline 66 & 0.166 & 2.84 & 3.01 & 5.4 & 5.1 & 4.0 \\
\hline 85 & 0.208 & 2.8 & 3.01 & 5.4 & 5.0 & 4.0 \\
\hline 28 & 0.109 & 2.9 & 3.01 & 5.4 & 5.0 & 4.0 \\
\hline
\end{tabular}


Table 4.6: The quantitation of nucleoside peaks from the HPLC traces for kinetic assays of RluA with labeled ASL. Relative integrations were adjusted with $\varepsilon_{260}$ for each nucleotide and normalized by assuming a value of 4.0 for $C$.

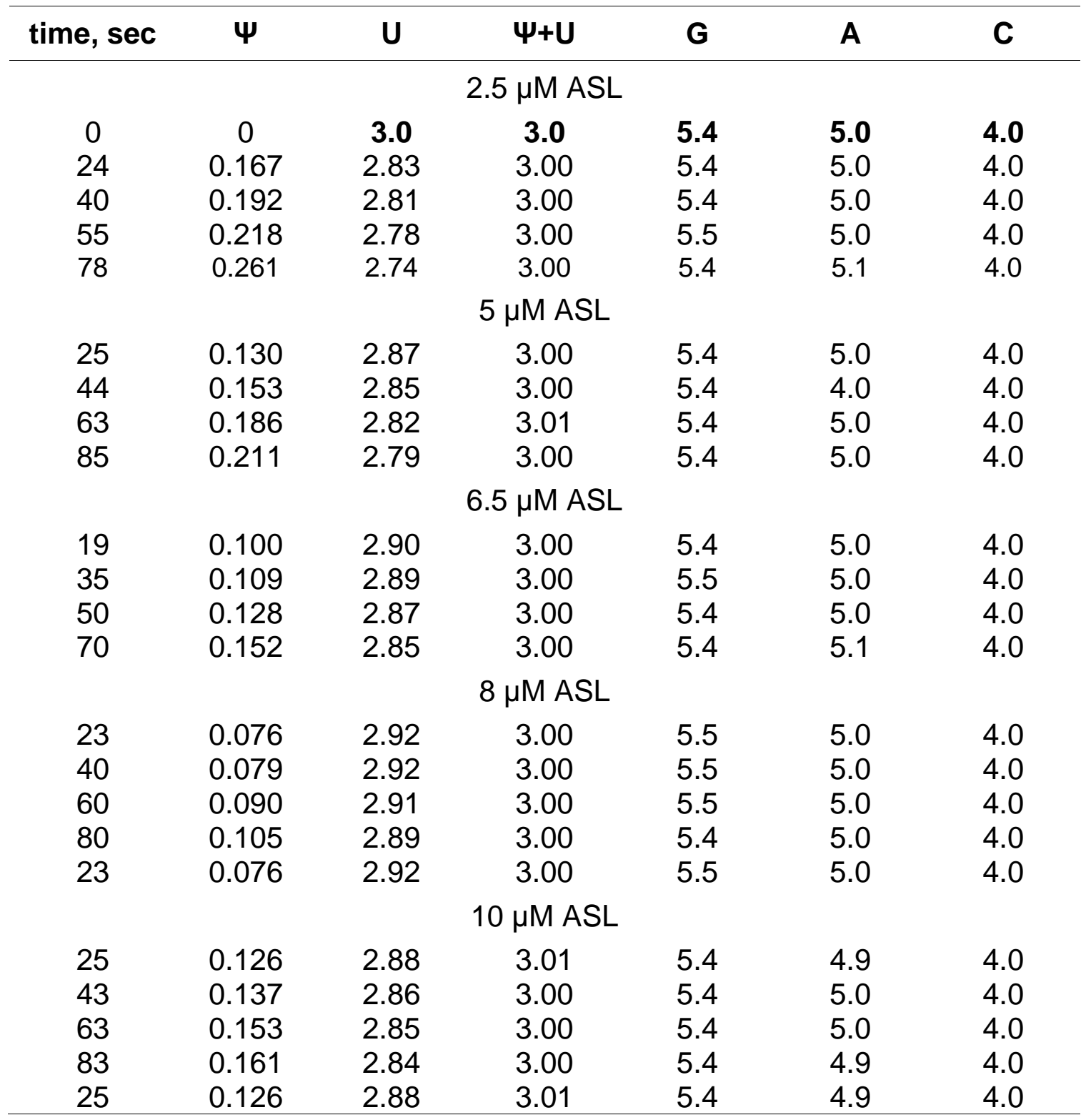




\section{Overall conclusions}

Three different mechanisms have been proposed for $\Psi$ synthases, and they all involve the conserved Asp acting as either a nucleophile or a base. [36, 43] In the 'Michael mechanism' (Figure 4.1), the conserved Asp acts as a nucleophile to attack C6 of the pyrimidine ring to form a Michael adduct. This mechanism was based on findings with TruA, which upon incubation with $\left[\mathrm{F}^{5} U\right] \mathrm{RNA}$ gets irreversibly inhibited and appears in an adduct band on denaturing PAGE gels.[36] The 'acylal' mechanism (Figure 4.2) instead proposes a nucleophilic attack at the $\mathrm{C}^{\prime}$ ' of the ribose ring by the conserved Asp. Studies with TruB provided more mechanistic clues into the action of $\Psi$ synthases. Whereas TruA and RluA form adducts when incubated with [ $\left.\mathrm{F}^{5} \mathrm{U}\right] \mathrm{RNA}$, TruB does not, nor does it get inhibited by [ $\left.\mathrm{F}^{5} \mathrm{U}\right] \mathrm{RNA}$ but instead converts $\mathrm{F}^{5} \mathrm{U}$ into two rearranged and hydrated products that differ in stereochemistry at $C 22^{\prime} .[25,43]$

${ }^{18} \mathrm{O}$ labeling studies with TruA, TruB, RluA, TruD and TmTruB [30, 41, 42, 67] all show that the hydration of the products of $F^{5} \mathrm{U}$ occurs directly from solution and not through the hydrolysis of a Michael adduct. A consistent scheme was then proposed by Mueller and co-workers for the hydration of $F^{5} \mathrm{U}$, and it has been slightly revised to accommodate the arabino product of $\mathrm{F}^{5} \mathrm{U}$ (Figure 2.23). By any mechanism, the $\Psi$ synthases rearrange $\mathrm{F}^{5} \mathrm{U}$, and idiosyncracies of the active site dictate its fate. In some active sites (TruA and RluA), the conserved Asp or some other nucleophile in the active site can reach $\mathrm{C} 6$ to make a stable adduct. The adduct, upon heating, undergoes elimination (rather than ester hydrolysis), followed by the spontaneous hydration of the rearranged $F^{5} U$ in solution. [30, 41] 
In other active sites (TruB, for example), the conserved Asp does not form a stable adduct with the pyrimidine, so the rearranged $\mathrm{F}^{5} \mathrm{U}$ is simply released into solution followed by hydration. This proposed scheme for hydration is consistent with TmTruB, which reversibly forms an adduct when incubated with [ $\left.\mathrm{F}^{5} \mathrm{U}\right] \mathrm{RNA}$ : after rearrangement, the $\mathrm{C}$-glycoside of $\mathrm{F}^{5} \mathrm{U}$ either gets trapped (whether by the conserved Asp or some other active site residue) or gets released into solution, where it becomes hydrated. The cocrystal structure of RluB with [ $\left.\mathrm{F}^{5} \mathrm{U}\right] \mathrm{RNA}$ [46] shows a covalent bond between the hydroxyl group of Tyr-146 and the pyrimidine ring of $F^{5} \mathrm{U}$, which is also consistent with the scheme that proposes the trapping of the rearranged $\mathrm{F}^{5} \mathrm{U}$.

Structural elucidation of the products of $\mathrm{F}^{5} \mathrm{U}$ by Miracco and Mueller [43] revealed that the major (ribo) and minor (arabino) products of $\mathrm{F}^{5} \mathrm{U}$ differ in their stereochemistry at $\mathrm{C2}^{\prime}$, which requires epimerization through the formation of a glycal intermediate. Either the conserved Asp or $\mathrm{O}^{2}$ of the pyrimidine ring can deprotonate $\mathrm{C}^{\prime}$ to form the glycal intermediate, and reprotonation of $\mathrm{C}^{\prime}$ from the "bottom" face yields the arabino product of $\mathrm{F}^{5} \mathrm{U}$. The existence of the arabino product strongly disfavors the Michael mechanism because the conserved Asp is tied up in an ester bond during the crucial deprotonation/reprotonation of $\mathrm{C}^{\prime}$. If $\mathrm{O}^{2}$ instead deprotonates the $\mathrm{C}^{\prime}$ ' by acting as a base, [87] the Michael mechanism may still be valid if solvent reprotonates C2'. However, the lack of deuterium washin for TruB and RluA with RNA containing $U$ and $F^{5} U$ discredits this hypothesis. [67] These results also favor the conserved Asp as the base for the deprotonation step because it gets the conserved Asp into its acid form to reprotonate C2' from 
the 'bottom' face. A variation of the Michael mechanism that can account for the arabino product would be the formation of the Michael adduct by the active site tyrosine residue, which would result in the conserved Asp remaining free to deprotonate and reprotonate $\mathrm{C}^{\prime}$. The $\Psi$ synthases share a conserved aromatic amino acid residue, which is a tyrosine in five of the six families (this Tyr-146 residue is adducted with [ $\left.F^{5} U\right] R N A$ in the RluB cocrystal). However, this hypothesis can also be discredited for several reasons. The fully functional TruD family has non-nucleophilic phenylalanine residues in this conserved position. [4850] Huang and co-workers found that substitution of this tyrosine residue in TruB with phenylalanine, leucine, or alanine resulted in an enzyme that can no longer handle the natural substrate (with $U$ ) but can handle [ $\left.F^{5} U\right] R N A$ to rearrange and hydrate $F^{5} U$. [51] If the tyrosine residue forms the initial Michael adduct, these variants should have left both $U$ and $F^{5} U$ unchanged (if the adduct does not form, no rearrangement to the $C$-glycoside should occur). Finally, the $\mathrm{pH}$ profile of TruB suggests that the active site tyrosine residue functions in its protonated form and thus is better suited to assist the $\mathrm{N}$-glycosidic bond cleavage of the uridine, by donating either a proton or hydrogen bond to the pyrimidine ring. [26, 52] Cleavage of $\mathrm{F}^{5} \mathrm{U}$ at the $\mathrm{N}$-glycosidic bond does not require the assisting tyrosine residue because the inductive effect of fluorine creates a better leaving group than with uridine.

The arabino product of $\mathrm{F}^{5} \mathrm{U}$ can be explained as part of the acylal mechanism (Figure 3.2). The decreased nucleophilicity of the fluorouracilate anion provides a longer lifetime for the acylal and oxocarbenium intermediates, thereby 
allowing them to access an alternate reaction pathway. The increased acidity of $\mathrm{C} 2$ ' in the oxocarbenium allows its deprotonation by the conserved Asp to form a glycal intermediate. Reprotonation of C2' from the "bottom" face would then result in the arabino product of $\mathrm{F}^{5} \mathrm{U}$.

The existence of a glycal intermediate along the reaction pathway of $F^{5} \mathrm{U}$ opens up a new mechanistic possibility, the 'glycal' mechanism (Figure 4.3) in which the glycal intermediate forms during the conversion of $U$ to $\Psi$. The low levels of deuterium wash-in observed in the $\mathrm{F}^{5} \mathrm{U}$ products with both wild-type and $\mathrm{Y} 76 \mathrm{~L}$ TruB (undetectable and $<4.5 \%$, respectively) indicate that the conserved Asp is sequestered from solvent on the time scale of conversion of $F^{5} U$ to its products and are consistent with a glycal intermediate along the $\mathrm{F}^{5} \mathrm{U}$ reaction pathway (whether it is the acylal mechanism, or glycal mechanism that operates).

The observed primary ${ }^{2} \mathrm{KIE}$ with TruB and RluA for $\mathrm{U}$ to $\Psi$ unambiguously indicates the operation of the glycal mechanism for these two $\Psi$ synthases from different families. The active sites of all six families have several conserved residues along with the absolutely conserved Asp that is essential for activity, [9, 10, 24-27] which strongly suggests that they all operate through a single mechanism, namely the 'glycal' mechanism. 


\section{REFERENCES}

1. Grosjean, H., Benne, R., Modification and eiting of RNA. 1998, Washington, DC.: ASM Press.

2. Davis, F.F. and F.W. Allen, Ribonucleic acids from yeast which contain a fifth nucleotide. J Biol Chem, 1957. 227(2): p. 907-15.

3. Johnson, L. and D. Soll, In vitro biosynthesis of pseudouridine at the polynucleotide level by an enzyme extract from Escherichia coli. Proc Natl Acad Sci U S A, 1970. 67(2): p. 943-50.

4. Carlile, T.M., M.F. Rojas-Duran, B. Zinshteyn, H. Shin, K.M. Bartoli, and W.V. Gilbert, Pseudouridine profiling reveals regulated mRNA pseudouridylation in yeast and human cells. Nature, 2014.

5. Lane, B.G., J. Ofengand, and M.W. Gray, Pseudouridine and O2methylated nucleosides. Significance of their selective occurrence in rRNA domains that function in ribosome-catalyzed synthesis of the peptide bonds in proteins. Biochimie, 1995. 77(1-2): p. 7-15.

6. Davis, D.R., Stabilization of RNA stacking by pseudouridine. Nucleic Acids Res, 1995. 23(24): p. 5020-6.

7. Auffinger, P. and E. Westhof, Effects of pseudouridylation on tRNA hydration and dynamics: a theoretical approach. Modification and Editing of RNA, 1998: p. 103-112.

8. Charette, M. and M.W. Gray, Pseudouridine in RNA: What, Where, How, and Why. IUBMB Life, 2000. 49(5): p. 341-351. 
9. Raychaudhuri, S., J. Conrad, B.G. Hall, and J. Ofengand, A pseudouridine synthase required for the formation of two universally conserved pseudouridines in ribosomal RNA is essential for normal growth of Escherichia coli. RNA, 1998. 4(11): p. 1407-17.

10. Conrad, J., L. Niu, K. Rudd, B.G. Lane, and J. Ofengand, 165 ribosomal RNA pseudouridine synthase RsuA of Escherichia coli: deletion, mutation of the conserved Asp102 residue, and sequence comparison among all other pseudouridine synthases. RNA, 1999. 5(6): p. 751-63.

11. Raychaudhuri, S., L. Niu, J. Conrad, B.G. Lane, and J. Ofengand, Functional Effect of Deletion and Mutation of theEscherichia coli Ribosomal RNA and tRNA Pseudouridine Synthase RluA. Journal of Biological Chemistry, 1999. 274(27): p. 18880-18886.

12. Ishida, K., T. Kunibayashi, C. Tomikawa, A. Ochi, T. Kanai, A. Hirata, C. Iwashita, and $\mathrm{H}$. Hori, Pseudouridine at position 55 in tRNA controls the contents of other modified nucleotides for low-temperature adaptation in the extreme-thermophilic eubacterium Thermus thermophilus. Nucleic Acids Res, 2011. 39(6): p. 2304-18.

13. Tortoriello, G., J.F. de Celis, and M. Furia, Linking pseudouridine synthases to growth, development and cell competition. FEBS J, 2010. 277(15): p. 3249-63.

14. Heiss, N.S., S.W. Knight, T.J. Vulliamy, S.M. Klauck, S. Wiemann, P.J. Mason, A. Poustka, and I. Dokal, $X$-linked dyskeratosis congenita is caused by mutations in a highly conserved gene with putative nucleolar functions. Nat Genet, 1998. 19(1): p. 32-8.

15. Luzzatto, L. and A. Karadimitris, Dyskeratosis and ribosomal rebellion. Nat Genet, 1998. 19(1): p. 6-7.

16. Mitchell, J.R., E. Wood, and K. Collins, A telomerase component is defective in the human disease dyskeratosis congenita. Nature, 1999. 402(6761): p. 551-5.

17. Bykhovskaya, Y., K. Casas, E. Mengesha, A. Inbal, and N. FischelGhodsian, Missense Mutation in Pseudouridine Synthase 1 (<i>PUS1</i>) Causes Mitochondrial Myopathy and Sideroblastic Anemia (MLASA). The American Journal of Human Genetics, 2004. 74(6): p. 1303-1308. 
18. Mueller, E.G., and Ferré-D'Amaré, A.R., Pseudouridine formation, the most common transglycosylation in RNA. In DNA and RNA Modification enzymes; Structure, Mechanism, Function and Evolution, H. Grosjean, Editor. 2009, Landes Bioscience: Austin, TX.

19. Joardar, A., S. Jana, E. Fitzek, P. Gurha, M. Majumder, K. Chatterjee, M. Geisler, and R. Gupta, Role of forefinger and thumb loops in production of Psi54 and Psi55 in tRNAs by archaeal Pus10. RNA, 2013. 19(9): p. 127994.

20. Hamma, T. and A.R. Ferré-D'Amaré, Pseudouridine synthases. Chem Biol, 2006. 13(11): p. 1125-35.

21. Arena, F., G. Ciliberto, S. Ciampi, and R. Cortese, Purification of pseudouridylate synthetase I from Salmonella typhimurium. Nucleic Acids Res, 1978. 5(12): p. 4523-36.

22. Cortese, R., H.O. Kammen, S.J. Spengler, and B.N. Ames, Biosynthesis of pseudouridine in transfer ribonucleic acid. J Biol Chem, 1974. 249(4): p. 1103-8.

23. Samuelsson, T. and M. Olsson, Transfer RNA pseudouridine synthases in Saccharomyces cerevisiae. J Biol Chem, 1990. 265(15): p. 8782-7.

24. McCleverty, C.J., M. Hornsby, G. Spraggon, and A. Kreusch, Crystal structure of human Pus10, a novel pseudouridine synthase. J Mol Biol, 2007. 373(5): p. 1243-54.

25. Spedaliere, C.J. and E.G. Mueller, Not all pseudouridine synthases are potently inhibited by RNA containing 5-fluorouridine. RNA, 2004. 10(2): p. 192-9.

26. Kaya, Y. and J. Ofengand, A novel unanticipated type of pseudouridine synthase with homologs in bacteria, archaea, and eukarya. RNA, 2003. 9(6): p. 711-21.

27. Kamalampeta, R., L.C. Keffer-Wilkes, and U. Kothe, tRNA binding, positioning, and modification by the pseudouridine synthase Pus10. Journal of molecular biology, 2013. 425(20): p. 3863-3874. 
28. Nurse, K., J. Wrzesinski, A. Bakin, B.G. Lane, and J. Ofengand, Purification, cloning, and properties of the tRNA psi 55 synthase from Escherichia coli. RNA, 1995. 1(1): p. 102-12.

29. Gu, X., M. Yu, K.M. Ivanetich, and D.V. Santi, Molecular recognition of tRNA by tRNA pseudouridine 55 synthase. Biochemistry, 1998. 37(1): p. 339-43.

30. Hamilton, C.S., T.M. Greco, C.A. Vizthum, J.M. Ginter, M.V. Johnston, and E.G. Mueller, Mechanistic investigations of the pseudouridine synthase RluA using RNA containing 5-fluorouridine. Biochemistry, 2006. 45(39): $p$. 12029-38.

31. Longley, D.B., D.P. Harkin, and P.G. Johnston, 5-fluorouracil: mechanisms of action and clinical strategies. Nat Rev Cancer, 2003. 3(5): p. 330-8.

32. Frendewey, D.A., D.M. Kladianos, V.G. Moore, and Kaiser, II, Loss of tRNA 5-methyluridine methyltransferase and pseudouridine synthetase activities in 5-fluorouracil and 1-(tetrahydro-2-furanyl)-5-fluorouracil (ftorafur)-treated Escherichia coli. Biochim Biophys Acta, 1982. 697(1): p. 31-40.

33. Heidelberger, C., N.K. Chaudhuri, P. Danneberg, D. Mooren, L. Griesbach, R. Duschinsky, R.J. Schnitzer, E. Pleven, and J. Scheiner, Fluorinated pyrimidines, a new class of tumour-inhibitory compounds. Nature, 1957. 179(4561): p. 663-6.

34. Santi, D.V., C.S. McHenry, and H. Sommer, Mechanism of interaction of thymidylate synthetase with 5-fluorodeoxyuridylate. Biochemistry, 1974. 13(3): p. 471-81.

35. Kammen, H.O., C.C. Marvel, L. Hardy, and E.E. Penhoet, Purification, structure, and properties of Escherichia coli tRNA pseudouridine synthase I. Journal of Biological Chemistry, 1988. 263(5): p. 2255-2263.

36. Gu, X.R., Liu, Y. Q., Santi, D. V., The mechanism of pseudouridine synthase $I$ as deduced from its interaction with 5-fluorouracil-tRNA. Proc Natl Acad Sci U S A., 1999. 96(25): p. 14270-14275.

37. Zhao, X. and D.A. Horne, The role of cysteine residues in the rearrangement of uridine to pseudouridine catalyzed by pseudouridine synthase I. Journal of Biological Chemistry, 1997. 272(3): p. 1950-1955. 
38. White, A., D. Tull, K. Johns, S.G. Withers, and D.R. Rose, Crystallographic observation of a covalent catalytic intermediate in a beta-glycosidase. Nat Struct Biol, 1996. 3(2): p. 149-54.

39. White, A., D. Tull, K. Johns, S.G. Withers, and D.R. Rose, Crystallographic observation of a covalent catalytic intermediate in a $\beta$-glycosidase. Nature Structural \& Molecular Biology, 1996. 3(2): p. 149-154.

40. Hoang, C. and A.R. Ferré-D'Amaré, Cocrystal structure of a tRNA Psi55 pseudouridine synthase: nucleotide flipping by an RNA-modifying enzyme. Cell, 2001. 107(7): p. 929-39.

41. McDonald, M.K., E.J. Miracco, J. Chen, Y. Xie, and E.G. Mueller, The handling of the mechanistic probe 5-fluorouridine by the pseudouridine synthase TruA and its consistency with the handling of the same probe by the pseudouridine synthases TruB and RluA. Biochemistry, 2011. 50(3): $\mathrm{p}$. 426-36.

42. Spedaliere, C.J., J.M. Ginter, M.V. Johnston, and E.G. Mueller, The pseudouridine synthases: revisiting a mechanism that seemed settled. J Am Chem Soc, 2004. 126(40): p. 12758-9.

43. Miracco, E.J. and E.G. Mueller, The Products of 5-Fluorouridine by the Action of the Pseudouridine Synthase TruB Disfavor One Mechanism and Suggest Another. Journal of the American Chemical Society, 2011. 133: p. 11826-11829.

44. Paul, D., S.E. O'Leary, K. Rajashankar, W. Bu, A. Toms, E.C. Settembre, J.M. Sanders, T.P. Begley, and S.E. Ealick, Glycal formation in crystals of uridine phosphorylase. Biochemistry, 2010. 49(16): p. 3499-509.

45. Singh, S., Miracco, E. J., Unpublished observations

46. Czudnochowski, N., G.W. Ashley, D.V. Santi, A. Alian, J. Finer-Moore, and R.M. Stroud, The mechanism of pseudouridine synthases from a covalent complex with RNA, and alternate specificity for U2605 versus U2604 between close homologs. Nucleic acids research, 2014. 42(3): p. 20372048. 
47. Phannachet, K. and R.H. Huang, Conformational change of pseudouridine 55 synthase upon its association with RNA substrate. Nucleic Acids Res, 2004. 32(4): p. 1422-9.

48. Kaya, Y., M. Del Campo, J. Ofengand, and A. Malhotra, Crystal structure of TruD, a novel pseudouridine synthase with a new protein fold. Journal of Biological Chemistry, 2004. 279(18): p. 18107-18110.

49. HOANG, C. and A.R. FERRÉ-D'AMARÉ, Crystal structure of the highly divergent pseudouridine synthase TruD reveals a circular permutation of a conserved fold. Rna, 2004. 10(7): p. 1026-1033.

50. KAYA, Y. and J. OFENGAND, A novel unanticipated type of pseudouridine synthase with homologs in bacteria, archaea, and eukarya. Rna, 2003. 9(6): p. 711-721.

51. Phannachet, K., Y. Elias, and R.H. Huang, Dissecting the roles of a strictly conserved tyrosine in substrate recognition and catalysis by pseudouridine 55 synthase. Biochemistry, 2005. 44(47): p. 15488-94.

52. Hamilton, C.S., C.J. Spedaliere, J.M. Ginter, M.V. Johnston, and E.G. Mueller, The roles of the essential Asp-48 and highly conserved His-43 elucidated by the $\mathrm{pH}$ dependence of the pseudouridine synthase TruB. Arch Biochem Biophys, 2005. 433(1): p. 322-34.

53. Joardar, A., S. Jana, E. Fitzek, P. Gurha, M. Majumder, K. Chatterjee, M. Geisler, and R. Gupta, Role of forefinger and thumb loops in production of $\psi 54$ and $\psi 55$ in tRNAs by archaeal Pus10. rna, 2013. 19(9): p. 1279-1294.

54. Lafontaine, D.L., C. Bousquet-Antonelli, Y. Henry, M. Caizergues-Ferrer, and $\mathrm{D}$. Tollervey, The box $H+A C A$ snoRNAs carry Cbf5p, the putative rRNA pseudouridine synthase. Genes \& development, 1998. 12(4): p. 527-537.

55. Watkins, N.J., A. Gottschalk, G. Neubauer, B. Kastner, P. Fabrizio, M. Mann, and R. Lührmann, Cbf5p, a potential pseudouridine synthase, and Nhp2p, a putative RNA-binding protein, are present together with Gar1p in all $H B O X / A C A-m o t i f$ snoRNPs and constitute a common bipartite structure. Rna, 1998. 4(12): p. 1549-1568. 
56. Phillips, B., A. Billin, C. Cadwell, R. Buchholz, C. Erickson, J. Merriam, J. Carbon, and S. Poole, The Nop60B gene of Drosophila encodes an essential nucleolar protein that functions in yeast. Molecular and General Genetics MGG, 1998. 260(1): p. 20-29.

57. Giordano, E., I. Peluso, S. Senger, and M. Furia, minifly, a Drosophila gene required for ribosome biogenesis. The Journal of cell biology, 1999. 144(6): p. 1123-1133.

58. Meier, U.T. and G. Blobel, NAP57, a mammalian nucleolar protein with a putative homolog in yeast and bacteria. The Journal of cell biology, 1994. 127(6): p. 1505-1514.

59. Gutgsell, N., N. Englund, L. Niu, Y. Kaya, B.G. Lane, and J. Ofengand, Deletion of the Escherichia coli pseudouridine synthase gene truB blocks formation of pseudouridine 55 in tRNA in vivo, does not affect exponential growth, but confers a strong selective disadvantage in competition with wildtype cells. RNA, 2000. 6(12): p. 1870-81.

60. Urbonavicius, J., J.M. Durand, and G.R. Bjork, Three modifications in the $D$ and $T$ arms of tRNA influence translation in Escherichia coli and expression of virulence genes in Shigella flexneri. J Bacteriol, 2002. 184(19): p. 534857.

61. Sage, A.E., A.I. Vasil, and M.L. Vasil, Molecular characterization of mutants affected in the osmoprotectant-dependent induction of phospholipase $C$ in Pseudomonas aeruginosa PAO1. Mol Microbiol, 1997. 23(1): p. 43-56.

62. Gustafsson, C., R. Reid, P.J. Greene, and D.V. Santi, Identification of new RNA modifying enzymes by iterative genome search using known modifying enzymes as probes. Nucleic Acids Res, 1996. 24(19): p. 375662.

63. Wouters, J., C. Tricot, V. Durbecq, M. Roovers, V. Stalon, and L. Droogmans, Preliminary $X$-ray crystallographic analysis of tRNA pseudouridine 55 synthase from the thermophilic eubacterium Thermotoga maritima. Acta Crystallogr D Biol Crystallogr, 2003. 59(Pt 1): p. 152-4.

64. Ramamurthy, V., S.L. Swann, J.L. Paulson, C.J. Spedaliere, and E.G. Mueller, Critical aspartic acid residues in pseudouridine synthases. J Biol Chem, 1999. 274(32): p. 22225-30. 
65. Lixuan Huang, Manee Pookanjanatavip,, Xiangrong Gu, and, Daniel V. Santi, A Conserved Aspartate of tRNA Pseudouridine Synthase Is Essential for Activity and a Probable Nucleophilic Catalyst. Biochemistry, 1998. 37(1): p. 344-351.

66. McDonald, M.K., E.J. Miracco, J. Chen, Y. Xie, and E.G. Mueller, The Handling of the Mechanistic Probe 5-Fluorouridine by the Pseudouridine Synthase TruA and lts Consistency with the Handling of the Same Probe by the Pseudouridine Synthases TruB and RluA. Biochemistry, 2010.

67. Singh, S., Unpublished observations.

68. Strohalm, M., D. Kavan, P. Novak, M. Volny, and V. Havlicek, mMass 3: a cross-platform software environment for precise analysis of mass spectrometric data. Anal Chem, 2010. 82(11): p. 4648-51.

69. Rose, F., Ueber die Verbindungen des Eiweiss mit Metalloxyden. Annalen der Physik, 1833. 104(5): p. 132-142.

70. Gill, S.C. and P.H. Von Hippel, Calculation of protein extinction coefficients from amino acid sequence data. Analytical biochemistry, 1989. 182(2): $p$. 319-326.

71. Bradford, M.M., A rapid and sensitive method for the quantitation of microgram quantities of protein utilizing the principle of protein-dye binding. Analytical biochemistry, 1976. 72(1): p. 248-254.

72. Green, A.A. and W.L. Hughes, [10] Protein fractionation on the basis of solubility in aqueous solutions of salts and organic solvents. Methods in enzymology, 1955. 1: p. 67-90.

73. Huber, R., T. Langworthy, H. König, M. Thomm, C. Woese, U. Sleytr, and $\mathrm{K}$. Stetter, Thermotoga maritima sp. nov. represents a new genus of unique extremely thermophilic eubacteria growing up to $90^{\circ} \mathrm{C}$. Archives of Microbiology, 1986. 144(4): p. 324-333.

74. Kibbe, W.A., OligoCalc: an online oligonucleotide properties calculator. Nucleic acids research, 2007. 35(suppl 2): p. W43-W46. 
75. Mori, S. and H.G. Barth, Size exclusion chromatography. 1999: Springer.

76. Amado, F.M.L., P. Domingues, M. Graça Santana-Marques, A.J. FerrerCorreia, and K.B. Tomer, Discrimination effects and sensitivity variations in matrix-assisted laser desorption/ionization. Rapid Communications in Mass Spectrometry, 1997. 11(12): p. 1347-1352.

77. Foster, P.G., L. Huang, D.V. Santi, and R.M. Stroud, The structural basis for tRNA recognition and pseudouridine formation by pseudouridine synthase I. Nature Structural \& Molecular Biology, 2000. 7(1): p. 23-27.

78. Spenkuch, F., G. Hinze, S. Kellner, C. Kreutz, R. Micura, T. Basché, and M. Helm, Dye label interference with RNA modification reveals 5-fluorouridine as non-covalent inhibitor. Nucleic acids research, 2014: p. gku908.

79. Albery, W.J., and Knowles, J.R., Energetics of Triosephosphate Isomerase: The Appearance of Solvent Tritium in Substrate Glyceraldehyde 3Phosphate and in Product. Biochemistry, 1976. 15: p. 5621-5626.

80. Albery, W.J., and Knowles, J.R., Efficiency and Evolution of Enzyme Catalysis. Angew. Chem. Int. Ed. Engl., 1977. 16: p. 285-293.

81. Singh, S. K., Miracco, E. J., unpublished observations

82. van Gunsteren, W.F., S. Billeter, A. Eising, P.H. Hünenberger, P. Krüger, A.E. Mark, W. Scott, and I.G. Tironi, Biomolecular simulation: The \{GROMOS96\} manual and user guide. 1996.

83. Guex, N. and M.C. Peitsch, SWISS-MODEL and the Swiss-Pdb Viewer: an environment for comparative protein modeling. electrophoresis, 1997. 18(15): p. 2714-2723.

84. DeLano, W.L., The PyMOL molecular graphics system. 2002.

85. Miracco, E.J., B. Bogdanov, and E.G. Mueller, Unexpected linear ion trap collision-induced dissociation and Fourier transform ion cyclotron resonance infrared multi-photon dissociation fragmentation of a hydrated $C$ glycoside of 5-fluorouridine formed by the action of the pseudouridine 
synthases RluA and TruB. Rapid Communications in Mass Spectrometry, 2011. 25(18): p. 2627-2632.

86. Ramamurthy, V., S.L. Swann, C.J. Spedaliere, and E.G. Mueller, Role of cysteine residues in pseudouridine synthases of different families. Biochemistry, 1999. 38(40): p. 13106-11.

87. Paul, D., S.n.E. O'Leary, K. Rajashankar, W. Bu, A. Toms, E.C. Settembre, J.M. Sanders, T.P. Begley, and S.E. Ealick, Glycal formation in crystals of uridine phosphorylase. Biochemistry, 2010. 49(16): p. 3499-3509.

88. Lowry, T.H. and K.S. Richardson, Mechanism and theory in organic chemistry. 1981.

89. Anderson, V.E. and W. Cleland, Phosphonate analog substrates for enolase. Biochemistry, 1990. 29(46): p. 10498-10503.

90. Gross, A., O. Abril, J.M. Lewis, S. Geresh, and G.M. Whitesides, Practical synthesis of 5-phospho-D-ribosyl. alpha.-1-pyrophosphate (PRPP): enzymatic routes from ribose 5-phosphate or ribose. Journal of the American Chemical Society, 1983. 105(25): p. 7428-7435.

91. Scott, L.G., T.J. Tolbert, and J.R. Williamson, [2] Preparation of specifically $2 \mathrm{H}$-and 13C-labeled ribonucleotides. Methods in enzymology, 2000. 317: p. 18-38.

92. Tolbert, T.J. and J.R. Williamson, Preparation of specifically deuterated RNA for NMR studies using a combination of chemical and enzymatic synthesis. Journal of the American Chemical Society, 1996. 118(34): p. 7929-7940.

93. Van Lanen, S.G., S.D. Kinzie, S. Matthieu, T. Link, J. Culp, and D. IwataReuyl, tRNA modification by S-adenosylmethionine: tRNA ribosyltransferase-isomerase assay development and characterization of the recombinant enzyme. Journal of Biological Chemistry, 2003. 278(12): p. 10491-10499.

94. Ames, B.N., [10] Assay of inorganic phosphate, total phosphate and phosphatases. Methods in enzymology, 1966. 8: p. 115-118. 
95. Arthur, P.K., L.J. Alvarado, and T.K. Dayie, Expression, purification and analysis of the activity of enzymes from the pentose phosphate pathway. Protein expression and purification, 2011. 76(2): p. 229-237.

96. Hennig, M., L.G. Scott, E. Sperling, W. Bermel, and J.R. Williamson, Synthesis of 5-Fluoropyrimidine Nucleotides as Sensitive NMR Probes of RNA Structure. Journal of the American Chemical Society, 2007. 129(48): p. 14911-14921.

97. Stambaugh, R.L.W., D. W., The chromatography of nucleotides, nucleosides, and pyrimidines and purines on activated charcoal. Journal of Chromatography A, 1959. 3: p. 221-224.

98. Sambrook, J., Neutral Polyacrylamide gel electrophoresis. Molecular cloning- A laboratory manual. 2001, NY: Cold Spring Harbor.

99. Milligan, J.F. and O. Uhlenbeck, Synthesis of small RNAs using T7 RNA polymerase. Methods in enzymology, 1989. 180: p. 51.

100. Macdonald, L.E., Y. Zhou, and W.T. McAllister, Termination and slippage by bacteriophage T7 RNA polymerase. Journal of molecular biology, 1993. 232(4): p. 1030-1047.

101. Kuzmine, I., P.A. Gottlieb, and C.T. Martin, Structure in nascent RNA leads to termination of slippage transcription by T7 RNA polymerase. Nucleic acids research, 2001. 29(12): p. 2601-2606.

102. Milligan, J.F., D.R. Groebe, G.W. Witherell, and O.C. Uhlenbeck, Oligoribonucleotide synthesis using T7 RNA polymerase and synthetic DNA templates. Nucleic Acids Res, 1987. 15(21): p. 8783-98.

103. Parkin,

G.; $\quad$ Available

at: http://www.columbia.edu/cu/chemistry/groups/parkin/isotope.html. 


\section{CURRICULUM VITAE \\ Govardhan reddy Veerareddygari}

\section{EDUCATION}

Ph. D. in Chemistry, Anticipated Graduation Date: October-December 2014

Dissertation: Mechanistic investigations of Pseudouridine synthases

University of Louisville (2008-Present)

Louisville, KY.

\section{M.S. in Chemistry}

Thesis: Mechanistic investigations of Pseudouridine synthases

University of Louisville (2012)

M.Sc in Biophysical Chemistry

University College of Science,

Osmania University,

Andhra Pradesh, India (2004-2006).

Areas of Concentration: Chemistry and Biology

AWARDS AND HONORS

- $\quad$ Graduate Research Assistantship at University of Louisville (2013present) 
- $\quad$ Graduate Teaching Assistantship at University of Louisville (20082012)

- Gold medal at University college of Science for excellence in the field of Biophysical Chemistry

\section{RESEARCH SKILLS}

- $\quad$ Experienced in handling RNA, purification and desalting using HPLC, In Vitro transcription of RNA using T7 RNA polymerase, qualitative and quantitative analysis of RNA by UV-Vis and HPLC.

- $\quad$ Modified pre-existing methods and successfully implemented onepot enzymatic synthesis of isotopically labeled nucleotide triphosphates for downstream usage in In Vitro transcription of labeled RNA oligonucleotides.

- Hands-on experience in organic synthesis (nucleotide phosphoramidite micro scale synthesis for downstream use in the synthesis of labeled RNA oligonucleotides) with running reactions under anhydrous conditions, extractions, separation of compounds using high vacuum distillation, and analysis using GC-MS, TLC and NMR (1D and 2D) (micro scale).

- $\quad$ Successfully designed, handled and completed research projects that involve enzyme kinetics with RNA substrates, recombinant DNA technology, cell culture, recombinant protein overexpression, purification and characterization.

- Highly experienced in handling instruments such as HPLC, GC, GCMS, MALDI-TOF Mass Spectrometry, UV-Vis, NMR and FPLC. Efficient in successfully designing and executing new analytical methods, qualitative and quantitative analysis of data, compiling reports and presentations. 
- $\quad$ Skilled with using analytical software such as Kaleidagraph ${ }^{\circledR}$, mMass $^{\circledR}$, ChemDraw ${ }^{\circledR}$, SciFinder ${ }^{\circledR}$, MestreNova $^{\circledR}$, Endnote $^{\circledR}$, and various other software including Microsoft Office ${ }^{\circledR}$, Adobe Illustrator ${ }^{\circledR}$, Adobe Photoshop ${ }^{\circledR}$. Proficient in using online databases such as SciFinder to compile relevant scientific data to support research needs.

\section{RESEARCH AND PROFESSIONAL EXPERIENCE}

Graduate Researcher (Fall 2008- Present)

Department of Chemistry, University of Louisville, Louisville KY

- Mechanistic investigations of a thermophilic pseudouridine synthase, Thermotoga maritima TruB (TmTruB) (2009-2013).

- Mechanistic investigations of a pseudouridine synthase Escherichia coli TruB (EcTruB) (2011).

- Kinetic isotope effects as a means to study the mechanism of pseudouridine synthases (2012-2014).

Chemistry Graduate Student Association (CGSA)-Secretary (Fall 2010Spring 2012)

Department of Chemistry, University of Louisville, Louisville KY

- Secretary (2010 - 2012). Organization and coordination of the banquets and hospitality events for the distinguished Nobel Laureates that were invited to speak at the University

- Host of the Annual Distinguished Lecturer Series.

2012 Richard R Schrock (2005 Nobel Prize in Chemistry)

2011 Ei-ichi Negishi (2010 Nobel Prize in Chemistry) 
- $\quad$ Organizing fun activities for graduate students, and act as a liaison for all Chemistry Graduate Students to the University GSA, and faculty.

Teaching Assistant- CHEM 546 Bio Chemistry (Spring 2009, Fall 201012)

Department of Chemistry, University of Louisville, Louisville KY

- Demonstration and supervision of course syllabus for each lab section. Responsibilities included knowledge of course content, hands on experience with the biochemical methods.

- Provided students with practical, hands-on experience in contemporary biochemical methods (uv/vis spectrophotometry, liquid chromatography, centrifugation, gel electrophoresis, 2D-NMR, matrixassisted laser-desorption ionization time-of-flight mass spectrometry (MALDI-TOF MS), and DNA methods) with a discovery-based approach.

Teaching Assistant- CHEM 445 Survey of Bio Chemistry (Spring 201113)

Department of Chemistry, University of Louisville, Louisville KY Learning objectives of the following course include,

- To understand biological processes and concepts from the chemical perspective.

- $\quad$ To effectively find, learn, and apply relevant biochemical knowledge.

- To critique biochemical information from a variety of sources including peer reviewed journal articles and determine the information's reliability, significance, and applicability to specific problems.

Teaching Assistant- CHEM 341 Organic Chemistry (Sumer 2010)

Department of Chemistry, University of Louisville, Louisville KY 
- An introductory organic chemistry laboratory course that teaches undergraduate students the basic techniques of organic synthesis.

Teaching Assistant- CHEM 103 General Chemistry (Spring 2012-13)

Department of Chemistry, University of Louisville, Louisville KY

- $\quad$ An introductory chemistry laboratory course that will allow freshmen undergraduate students experience and explore chemical phenomena.

\section{POSTERS AND PRESENTATIONS}

Oral Presentation (October 2014)

The 34 ${ }^{\text {th }}$ Midwest Enzyme Chemistry Conference, Northwestern University, Evanston, IL

- "A primary 2'-deuterium kinetic isotope effect indicates that pseudouridine synthases proceed through a glycal intermediate" Govardhan reddy Veerareddygari and Eugene G. Mueller.

Poster Presentation (July 2014)

Enzymes, Coenzymes and Metabolic pathways, Gordon Research Conferences, Waterville Valley, $\mathrm{NH}$

- "Mechanistic studies of the Pseudouridine synthase Thermotoga maritima TruB" Govardhan reddy Veerareddygari and Eugene G. Mueller.

Poster Presentation (March 2013)

The Institute for Molecular Diversity and Drug Design Symposium, Jewish Hospital and St. Mary's HealthCare, Louisville KY

- "Mechanistic investigations of a Pseudouridine synthase Thermotoga maritima TruB (TmTruB)-2" Govardhan reddy Veerareddygari and Eugene G. Mueller. 
Poster Presentation (March 2012)

The Institute for Molecular Diversity and Drug Design Symposium, Jewish Hospital and St. Mary's HealthCare, Louisville KY

- "Mechanistic investigations of a Pseudouridine synthase Thermotoga maritima TruB (TmTruB)-1" Govardhan reddy Veerareddygari and Eugene G. Mueller.

Poster Presentation (March 2012)

Rustbelt RNA Meeting (RRM), Dayton, OH

- "The initial kinetic characterization of a thermophilic pseudouridine synthase (Thermotoga maritima TruB)" Govardhan reddy Veerareddygari and Eugene G. Mueller.

Poster Presentation (June 2012)

Göttingen, Germany

- "Looking for an intermediate: Wash-in studies to probe the Pseudouridine synthase reaction" Eugene G. Mueller, Edward J. Miracco, Sanjay K. Singh and Govardhan reddy Veerareddygari

MEMBERSHIPS

- Institute of Molecular diversity and drug design (IMD3) (March 2010-present)

- $\quad$ Rustbelt RNA society (2010-present) 